Susanne Hartwig (ed.)

\title{
Inclusión, integración, diferenciación
}

La diversidad funcional en la literatura, el cine y las artes escénicas 
IMAGES OF DISABILITY. LITERATURE, SCENIC, VISUAL, AND VIRTUAL ARTS 2

Susanne Hartwig (ed.)

\section{Inclusión, integración, diferenciación}

La inclusión es un tema de gran actualidad en muchos ámbitos de la vida contemporánea. Son muy amplios los sectores en los que se viene observando un considerable aumento de la sensibilidad social acerca de las circunstancias y condiciones en que se produce. El presente libro tiene dos intereses centrales: analizar la relación entre personas con y sin diversidad funcional en los textos culturales a través de los tres términos clave inclusión, integración, diferenciación; y estudiar en los textos concretos cómo se tratan o incluso se practican la inclusión, la integración y la diferenciación. El campo de estudio se orienta hacia el corpus de los textos literarios, teatrales y audiovisuales.

\section{The Editor}

Susanne Hartwig es Catedrática de Literatura y Culturas Románicas de la Universidad de Passau (Alemania) desde el año 2006. Sus líneas de investigación son literatura y ética (dilema y diversidad), diversidad funcional, teatro y cine contemporáneo, narrativa contemporánea en América Latina, literatura y ciencia cognitiva. 
Inclusión, integración, diferenciación 


\title{
IMAGES OF DISABILITY / IMÁGENES DE LA DIVERSIDAD FUNCIONAL
}

\author{
Literature, Scenic, Visual, and Virtual Arts / \\ Literatura, artes escénicas, visuales y virtuales \\ Edited by \\ Susanne Hartwig and Julio Enrique Checa Puerta
}

VOLUME 2

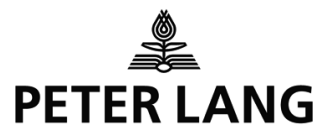


Susanne Hartwig (ed.)

\section{Inclusión, integración, diferenciación}

La diversidad funcional en la literatura, el cine y las artes escénicas




Bibliographic Information published by the Deutsche Nationalbibliothek The Deutsche Nationalbibliothek lists this publication in the Deutsche Nationalbibliografie; detailed bibliographic data is available online at http://dnb.d-nb.de.

Unterstützt durch den Publikationsfonds der Universität Passau

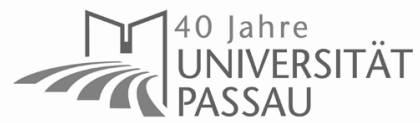

El libro ha sido publicado gracias al apoyo del programa Hispanex

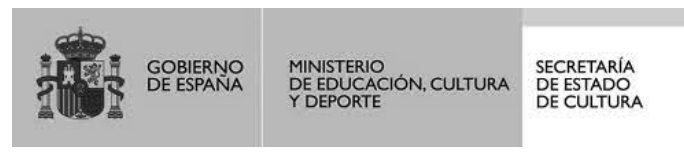

ISSN 2569-586X

ISBN 978-3-631-79803-4 (Print) • E-ISBN 978-3-631-81505-2 (E-Book) E-ISBN 978-3-631-81506-9 (EPUB) • E-ISBN 978-3-631-81507-6 (MOBI) DOI $10.3726 / \mathrm{b} 16655$


Open Access: This work is licensed under a Creative Commons Attribution NonCommercial NoDerivatives 4.0 unported license. To view a copy of this license, visit https://creativecommons.org/licenses/by-nc-nd/4.0/

(c) Susanne Hartwig

Peter Lang GmbH International Academic Publishers Berlin 2020

Peter Lang - Berlin · Bern · Bruxelles · New York ·

Oxford $\cdot$ Warszawa $\cdot$ Wien

www.peterlang.com 


\section{Contenido}

\section{Susanne Hartwig}

Introducción: los mundos posibles y la inclusión de la diversidad

funcional

\section{Inclusión en el escenario}

Julio Enrique Checa Puerta

El Festival ÍDEM, la mediación del marco legal entre la producción y la creación artística

David Ojeda Abolafia

La metaescena: la inclusión artística y la accesibilidad espectacular

Marta Cantero Díaz

Entidad declarada de utilidad pública. Asociación Paladio Arte

David Ojeda

Palmyra Teatro

Esmeralda Valderrama Vega

¿Qué es Danza Mobile?

\section{Inclusión y expresión personal}

Beth E. Jörgensen

La escritura autobiográfica de la discapacidad: la teoría articulada en primera persona

Alejandra M. Aventín Fontana

(Im)pactos de la poesía en la representación de la diversidad funcional. "Peregrina de mí he ido hacia la que duerme en un país al viento": la palabra integradora de Alejandra Pizarnik

Berit Callsen

Cuerpo y mente extraordinarios: formas de inclusión y concepción de figuras en la obra cuentística de Guadalupe Nettel 
Katarzyna Nowak-McNeice

Autism and the Challenges of Translation: on the Example of Rafał Motriuk's Autistic Son, Desperate Dad (2018)

\section{Inclusión y narración}

Susan Antebi

Transparencia jurídica y escritura corporal: una mirada oblicua a

Carta sobre los ciegos de Mario Bellatin

Adrián Herrera-Fuentes

De la inocencia a la rebelión. Diversidad funcional y la esperanza de una historia alternativa: Marianela (1878) de Benito Pérez Galdós y Los santos inocentes (1981) de Miguel Delibes

Javier Luis Velloso Álvarez

Cuerpos estancados, memorias evanescentes: Imágenes de la discapacidad y de la dependencia física, psíquica y sensorial en la narrativa de Rafael Chirbes

Alejandro F. Gasel

Posiciones de los sujetos con discapacidad en la narrativa argentina reciente

\section{Inclusión a través de una mirada diferente}

Christian von Tschilschke

La discapacidad como 'tenor' y 'vehículo' en La rabia de Albertina Carri .... 203

Beatriz Miranda Galarza

De la norma al nombre: el arte y la invitación a reinventar el activismo en la "discapacidad"

Patricia Brogna

Plemya: regresando a la tribu 


\section{Inclusión entre othering y normalización}

Susanne Hartwig

Cuestión de perspectiva: la diversidad funcional en el cine contemporáneo 253

Ryan Prout

Still Waters Run Deep Disability Counter Currents in La piscina (2012) ..... 275

Mirjam Leuzinger

¿Hacia un séptimo arte inclusivo? El cine brasileño a través del prisma de los disability studies

Sobre los autores 309 



\author{
Susanne Hartwig
}

Universität Passau

\title{
Introducción: los mundos posibles y la inclusión de la diversidad funcional
}

\begin{abstract}
What kind of knowledge or impact can art generate that activism and theory alone cannot?
\end{abstract}

(Malzacher 2015: 14)

Inclusión es un término de gran actualidad -no solo en Europa- que abarca muchísimos sectores sociales en los más diversos ámbitos de la vida contemporánea. Con respecto a la diversidad funcional, ${ }^{1}$ su relevancia se manifiesta, sobre todo, en la aprobación de la Convención Internacional sobre los Derechos de las Personas con Discapacidad por las Naciones Unidas en el 2006 (firmada y ratificada por España y los países hispanohablantes de América Latina a partir del 2007). Esta Convención protege y garantiza los principios de la no discriminación y la "participación e inclusión plenas y efectivas en la sociedad" de personas con discapacidades (Naciones Unidas 2006). En concreto, el artículo 30 garantiza el derecho, a la participación activa y pasiva en la vida cultural "en igualdad de condiciones con las demás [personas]" (Naciones Unidas 2006). El objetivo es proteger los derechos y la dignidad de las personas con diversidad funcional.

Sin embargo, el concepto detrás del término inclusión es más bien borroso. ${ }^{2}$ Según una definición básica proveniente de la sociología -disciplina matriz de la

1 El término diversidad funcional se acuña en 2005 (Romañach/Lobato 2005) para reemplazar otros términos considerados peyorativos, como discapacidad o minusvalía. En la presente contribución, se utilizarán indistintamente los términos diversidad funcional y discapacidad.

2 Otra dificultad es que la diferenciación de los términos clave de la discusión varía en los diferentes idiomas. Felder afirma: "As John Wilson [...] pointed out, the concept of inclusion lacks the necessary conceptual lucidity; it is a vague term, loaded with numerous economic, social, political, and cultural connotations and used in a broad range of fields, in different disciplines as well as practical and political contexts" (2013: 300). Una visión general excelente sobre la complejidad de la terminología acerca de la inclusión y de la exclusión se encuentra en Ravaud/Stiker (2001). 
discusión-, inclusión significa la involucración estructural de individuos en los distintos contextos (sistemas) sociales. ${ }^{3}$ Entiéndase bien: esta definición no dice nada sobre la calidad ni la intensidad de la involucración; ${ }^{4}$ puede remitir a una inclusión "en igualdad de condiciones" o, al contrario, a una inclusión con segregación interna. Según esta definición, por ejemplo, las escuelas de educación especial se consideran una inclusión de las personas con discapacidad, porque el sistema educativo las identifica como elementos suyos. Wansing afirma que el sistema educativo incluye a un alumno de una escuela especial tanto como a un profesor universitario; asimismo, una persona desempleada de larga duración y con una grave discapacidad está tan incluida en el sistema económico como un empresario exitoso. ${ }^{5}$

Un subsistema social (por ejemplo, 'educación escolar') puede incluir a una persona sin dejar de desarrollar subsistemas excluyentes dentro de esta inclusión (por ejemplo, 'escuela regular' vs. 'escuela especial'); si vuelve a practicar la inclusión en el subsistema (por ejemplo, 'inclusión de las personas con discapacidad en las escuelas regulares'), es capaz de formar nuevos subsistemas (del tipo 'escuela regular inclusiva-grupo A' vs. 'escuela regular inclusiva-grupo B'). ${ }^{6}$ Las secuencias del tipo 'inclusión en el sistema, seguida por exclusión en el subsistema' se deben al hecho de que algunos sistemas sociales no se prestan fácilmente a la inclusión en su estado actual por las reglas que los dominan: si

3 Luhmann concibe la inclusión como mecanismo básico de la sociedad moderna. En su teoría (véase, por ejemplo, Luhmann 1997), los individuos existen para los subsistemas sociales (como la educación, la ciencia, la economía, el arte, etc.) a través de las distinciones básicas de estos subsistemas. Sobre la inclusión según Luhmann véanse Wansing (2007) y Rösner (2014: 159-160).

4 La inclusión deja participar a una persona en un sistema sin prescribir la forma en la que debe participar. De hecho, no significa necesariamente que una persona participe en un sistema de manera significativa. La persona incluida es libre pero no está necesariamente 'consolidada' entre los demás miembros de un sistema. Véase la diferenciación de distintas formas de inclusión/exclusión en Ravaud/Stiker: "differentiated inclusion", "conditional inclusion", inclusión mediante una normalización e inclusión a través de una discriminación (2001: 504-507). Sobre una diferenciación de los términos inclusión, integración y participación véase Kastl (2017: 233-244).

5 "Ein Sonderschüler ist nicht weniger in das Bildungssystem inkludiert als ein Universitätsprofessor, und ein langzeitarbeitsloser, schwerbehinderter Mensch ist ebenso in das Wirtschaftssystem inkludiert wie ein erfolgreicher Unternehmer" (Wansing 2007: 280).

6 Ravaud/Stiker hablan de una lógica de las sociedades modernas: "Modern societies have a very great capacity for inclusion but, on the other hand, are in danger of pulling apart by creating enclaves within themselves" (2001: 491). 
la escuela tiene como objetivo la selección y/o la preparación para una selección futura, virtualmente no puede incluir a todas las personas sin contradicción (o modificar su regla fundamental y correr el peligro de perder su identidad). La conciliación entre las dos exigencias -selección e inclusión- es virtualmente imposible, y camuflarlo lleva a construcciones paradójicas.

La diferenciación inherente a la segregación de personas con diversidad funcional, por ejemplo, en el sistema escolar, se justifica con la innegable diversidad de estas personas y con la promesa de una futura inclusión (posible): se separa a algunos alumnos en instituciones especiales para prepararlos para un futuro mercado sin separación (es decir, se las excluye con el propósito de incluirlas mejor más tarde). ${ }^{7}$ Sobra añadir que la mayoría de los alumnos provenientes de escuelas especiales no consigue su título escolar, lo que significa que su escolarización cimenta su futura marginalización en el mercado laboral. ${ }^{8}$ Wansing (2007: 288) afirma que no es la falta de intentos de inclusión lo que plantea los graves problemas de marginalización para las personas con discapacidad sino la manera de incluirlas, por lo cual propone concebir la discapacidad no como una consecuencia de la exclusión sino de la inclusión.

No obstante, en muchos discursos (oficiales), el término inclusión se utiliza como si excluyera automáticamente la segregación o la asimilación. Este tipo de inclusión es muy particular: se trata de una 'inclusión ideal' que abarca mucho más que una simple involucración de personas con discapacidad en la vida social, donde estas no solo forman (pasivamente) una parte del sistema social, sino que desarrollan (activamente) sus capacidades para formar una parte significativa, reconocida enteramente, en el sistema social actual y también futuro. Los subsistemas de la 'inclusión ideal' no son excluyentes, sino que concilian diversidad y libertad de elegir. Se trata de una inclusión con integración en un sistema diferenciado, condicionado por todos sus miembros en igualdad de derechos, sin asimilación a las normas de un grupo particular, sin segregación ni marginalización ni indiferencia. ${ }^{9}$

7 Ravaud/Stiker hablan del "segregating 'detour", "to regain the mainstream": "Thus, the intention is not to exclude but to include at a future date. The goal of sequestration is no longer confinement, as in the seventeenth century, but a mediated inclusion" (2001: 505).

8 Kastl (2017: 225) hace hincapié en el hecho de que muchos proyectos 'inclusivos' en el área de la cultura y del deporte se transforman en mundos paralelos. Véase también Wansing (2007).

9 Sobre tales tipos de inclusión véanse Ravaud/Stiker (2001: 501), Felder (2013: 301302), Rösner (2014: 158). Sobre las distintas formas de diferenciación (la forma jerárquica y la yuxtaposición) y sus peligros véanse Ravaud/Stiker (2001: 499-500). 
De estas consideraciones sobre el significado del término inclusión se desprenden tres problemas centrales en la discusión sobre el concepto: a) pretender que la inclusión sustituye a la integración o la vuelve superflua, b) considerar la inclusión algo de por sí positivo, y c) homogeneizar la diversidad (funcional) para incluirla en un sistema.

a) La inclusión puede acercarse a la mera tolerancia, que muchas veces significa también indiferencia. ${ }^{10}$ La integración, en cambio, asegura la estructura de un grupo social y, por ende, una interconexión de los miembros de este grupo (véase Kastl 2017: 234). En un sistema social integrado existen relaciones sociales recíprocas entre los miembros, o sea, se forma una red de comunicaciones e interacciones que los coordina (véase Kastl 2017: 237). ${ }^{11}$ Un grupo con miembros integrados se basa en normas y valores compartidos. Cuando surgen conflictos, recurre a formas de resolverlos reconocidas por todos. ${ }^{12} \mathrm{La}$ integración no supone automáticamente una relación de poder o de dominancia, ${ }^{13}$ sino que puede realizarse con igualdad de derechos sin que la persona integrada pertenezca necesariamente a una minoría ni que se asimile a un grupo ya existente (véase la crítica de Kastl 2017: 235): siempre es posible para los miembros de un grupo social integrarse en un nuevo nivel cuando se acogen miembros nuevos. No hay que confundirla con la asimilación, que es un tipo particular de la integración, o sea, una integración unilateral en la que un grupo dominante adapta sus reglas ya constituidas a los miembros nuevos.

Inclusión, integración y diferenciación son tres aspectos distintos del acto de involucrar a personas en un sistema social, y cada uno plantea el problema de la relación conflictiva entre libertad e igualdad: el peligro que corre la inclusión con poca o nula integración es enfatizar demasiado la libertad, el que corre la

10 Véase lo que afirman Ravaud/Stiker: "[Inclusion] can prove to be weak, a synonym for simple presence, simple admittance, and simple tolerance. One can be supported without being recognized. One can be received without being incorporated. [...] Being fully recognized as an equal, a partner, or a participant with the same dignity and of the same quality as any other is called integration rather than inclusion" (2001: 501).

11 Integración se refiere al tipo y a la extensión de la involucración de los individuos en relaciones sociales y a la cohesión de los contextos sociales (Kastl 2017: 236).

12 Véase lo que Kastl (2017: 234) escribe sobre la integración en una clase escolar: las disposiciones individuales cuadran con el contexto y cada individuo se identifica con el grupo.

13 En la literatura sobre inclusión se encuentran muy a menudo afirmaciones como la de Rösner (2014: 158) que dice que en la integración se expresa una relación de dominancia y de sumisión entre el que integra y el que se deja integrar. 
integración con poca o nula diferenciación es sobrevaluar la igualdad. La inclusión con integración y diferenciación puede equilibrar las dos exigencias: la de libertad y la de igualdad.

b) En muchos discursos, la palabra inclusión connota algo exclusivamente positivo; también se reivindica a menudo de manera indiferenciada, como si pudiera generalizarse a todos los sectores de la sociedad a la vez. Sin embargo, los requisitos que permiten a las personas participar en los distintos sectores de la vida social están estrechamente relacionados con funciones corporales, mentales o psíquicas específicas (véase Kastl 2015: 282), que limitan una posible inclusión y determinan distintos tipos de ella. ${ }^{14} \mathrm{Si}$ se incluye a una persona en un sistema social en el que, por sus condiciones, es virtualmente incapaz de participar, una inclusión forzada amenaza el contenido específico de este sistema.

Estas circunstancias pueden ilustrarse con el ejemplo de un partido de fútbol: si una persona A que se mueve en silla de ruedas quisiera participar en un partido de fútbol como jugador, se le abren las siguientes posibilidades de inclusión:

a) se crea un paradeporte exclusivo para personas en silla de ruedas (inclusión + separación + diferenciación)

b) se buscan nuevas reglas que valgan para todos los jugadores (con y sin diversidad funcional) de manera que el juego entero cambia su carácter (inclusión + integración + asimilación)

c) en unas partes del juego valen las reglas conocidas del fútbol, en otras partes, las reglas que favorecen a la persona $\mathrm{A}$, y en algunas partes, se crean reglas nuevas (inclusión + integración + diferenciación). ${ }^{15}$

La dificultad en las posibilidades b) y c) salta a la vista: las nuevas reglas hacen perder las características específicas conocidas de un partido de fútbol. De hecho,

14 Los disability studies parecen a veces criticar cualquier concepto de normalidad (como expresión de estructuras de poder); sin embargo, la normalidad en si no tiene por qué ser mala; también puede considerarse un equilibro hacia el que se mueve una sociedad sin que entre una relación de dominación/subordinación. Por supuesto, esta normalidad podría incluir a la diversidad funcional.

15 El tercer tipo de inclusión parece realizarse, por ejemplo, en el teatro inclusivo Rambazamba (Berlín). La directora Gisela Höhne afirma que no pretende suprimir las diferencias: no quiere que las personas con diversidad funcional se asimilen a los actores sin diversidad funcional ni que estos nieguen sus propias capacidades (Höhne 1999: 95). 
la inclusión de todos en igualdad de condiciones es capaz de hacer desaparecer el sistema en el que se pretende incluir a todos. Una inclusión total, o sea, el incluir a todos los miembros de una sociedad en todas las partes de una sociedad, desemboca en una desdiferenciación de esta sociedad, puesto que su estructura se basa, entre otros, en las competencias de sus miembros y el reconocimiento de las mismas. ${ }^{16}$

Muchas veces chocan los intereses opuestos, pero igualmente válidos. Rösner (2014: 299) habla de una "tensión" (Spannungsverhältnis) entre igualdad normativa y diversidad real. ${ }^{17}$ Lo que significa inclusión para una persona puede muy bien significar exclusión para otra. Sirva de ejemplo la accesibilidad: la falta de bordillos ayuda a la persona en silla de ruedas a acceder a la acera, pero perjudica a la persona no vidente con bastón; si se quitaran todas las barreras cognitivas empleando siempre un lenguaje fácil, la libertad y las posibilidades de describir y argumentar de manera diferenciada (por ejemplo, en la ciencia) serían (demasiado) restringidas (el ejemplo es de Kastl 2017: 105). Se perjudicaría a la diversidad social. En todas las circunstancias que requieren el desarrollo o la perfección de una capacidad humana, el acceso es restringido y debe serlo (solo hay que pensar, por ejemplo, en una operación quirúrgica o en un simple coro musical). Una accesibilidad total se realizaría en detrimento de esta perfección. ${ }^{18} \mathrm{De}$ estas consideraciones se deduce que hay que distinguir una inclusión deseable, de otra, problemática.

c) El término diversidad funcional hace pensar en una homogeneidad que no existe. Sería más preciso hablar de las diversidades funcionales porque son heterogéneas, y la inclusión debería serlo también. Lo que se aprecia para un tipo de diversidad funcional no vale necesariamente para otro. Sin embargo, muchos debates sobre la inclusión tienden a allanar las diferencias. Kastl (2015: 282) argumenta con el ejemplo de un partido de fútbol con una persona con síndrome de Down, en comparación con un partido con una persona tetrapléjica: ambas

16 La inclusión total pondría fin a la diferencia. Por ejemplo, si la enseñanza tratara a todos los alumnos de una manera distinta, ya no dejaría desarrollarse estándares para distinguir las competencias de los alumnos (Kastl 2017: 202).

17 Todavía faltan teorías que discutan detenidamente la relación entre inclusión y diversidad; los dos conceptos a veces coinciden, otras veces se oponen: "There is diversity in exclusion and diversity in inclusion”, afirman Ravaud/Stiker (2001: 501). Por ejemplo, la separación escolar puede considerarse una exclusión de la diversidad o, al contrario, un reconocimiento de ella. Sería deseable que se indague más en la relación entre diversidad social e igualdad de oportunidades (Wansing 2014: 210).

18 Véanse también los argumentos de Kastl (2015: 279). 
diversidades funcionales condicionan (y restringen) distintos tipos de inclusión. Quien generaliza lo que vale para la primera persona, brinda una visión sesgada de la inclusión posible para la segunda, y unifica donde tendría que diferenciar. ${ }^{19}$ No todas las diversidades son iguales ni lo son sus efectos sobre un sistema social.

De las consideraciones anteriores se puede concluir que el concepto de inclusión es proclive a tensiones y conflictos. La diversidad funcional marca una discrepancia entre individuo y entorno, una característica de un individuo que no cuadra automáticamente con la práctica social habitual. ${ }^{20}$ Puesto que los textos estéticos (en el sentido amplio de la palabra) tratan de los mundos posibles (literatura, teatro, cine, novela gráfica, etc.), brindan contextos sociales particularmente abiertos y poco fijados, por lo que la desviación no se distingue tan fácilmente como es el caso en la práctica social cotidiana, ${ }^{21}$ ya que la ficción es capaz de mantener ambigüedades y ambivalencias que la realidad social debe suprimir para funcionar. ${ }^{22}$ Por eso, los mundos posibles de los textos estéticos parecen ser el lugar idóneo para experimentar nuevos tipos de acoplamiento entre individuo y entorno porque abren la práctica social hacia nuevas posibilidades. Son capaces de posicionar la diversidad funcional en contextos inesperados y de crear así alternativas a la práctica social en vigor. Parecen ser el lugar más apropiado para modelos de inclusión y experimentos con ella.

Hasta el momento, el tema de la inclusión se debate sobre todo en el área de la sociología y de las ciencias pedagógicas. Los estudios culturales, en cambio, se conforman con un uso borroso de la palabra inclusión y un concepto sumario. La mayoría de las veces, la palabra figura como adjetivo: se habla de cine inclusivo o teatro inclusivo, de talleres o festivales inclusivos, sobre todo para señalar el hecho de que personas con diversidad funcional participan en ellos, sin precisar la calidad de esta participación y la relación entre este tipo de cine o de teatro y las prácticas sociales reales. Faltan todavía teorías básicas que deriven su enfoque específico de la relación entre inclusión, integración y diferenciación (y los respectivos conceptos opuestos: exclusión, desintegración/fragmentación

19 Kastl (2015: 282) critica que muchos discursos sobre la inclusión homogeneizan demasiado el concepto de discapacidad suprimiendo las diferencias al construir un grupo uniformado.

20 Kastl (2017: 80) habla de una "ecuación" entre las prácticas sociales y el individuo; cada práctica social define expectativas y exigencias complejas (Kastl 2017: 58).

21 Parr (2008: 32) habla de la predilección de la literatura por lo excluido, por la experiencia de los límites y por las infracciones.

22 Corbineau-Hoffmann llama a la ambigüedad (Vieldeutigkeit) el "criterio distintivo" (Differenzkriterium) de los textos literarios (2017: 247). 
y asimilación). Una pregunta fundamental por parte de los estudios culturales sería si las obras inclusivas crean mundos paralelos (separación dentro de la inclusión) o más bien integrados en un sistema estético común, o sea, si diferencian o asimilan a las personas con diversidad funcional. Cuando los textos estéticos hablan de inclusión, se debe precisar bien de qué tipo de inclusión se trata, y si la inclusión aumenta las posibilidades creativas (Gestaltungsspielraum) para la relación entre personas con y sin diversidad funcional en un espacio común.

Una definición muy general de una inclusión estética (es decir, una inclusión a través de los mundos posibles) debería referirse a todo tipo de inclusión realizada a través de un medio que requiere a una perspectiva estética, o sea, una perspectiva que suspende a la distinción entre verdadero y falso, y que presuponga un receptor (lector o espectador) capaz de percibirla e interpretarla. Con eso, se distinguiría de otros tipos de inclusión como la inclusión escolar, laboral, deportiva, etc. Los textos estéticos -novelas, teatro, cine, etc.- pueden incluir a las personas con diversidad funcional de distintas maneras: como tema, como elemento constitutivo de la mediación (por ejemplo, actores con diversidad funcional), como elemento constitutivo de la producción (por ejemplo, una persona con diversidad funcional en calidad de (co)diseñador de lo narrado/presentado) o como elementos del proceso de la recepción (por ejemplo, a través de la accesibilidad de las salas de teatro o de cine).

El presente volumen reúne las conferencias del congreso internacional "Inclusión, integración, diferenciación: la diversidad funcional en la literatura, el cine y las artes escénicas", celebrado del 29 de noviembre al 2 de diciembre del 2018 en la Universidad de Passau. ${ }^{23}$ Se indagó el potencial de la ficción como espacio de negociación entre distintas construcciones sociales partiendo de la pregunta planteada por Malzacher que sirve de lema introductorio: ¿cuál es el aporte del arte al debate sobre la inclusión?

23 Con este congreso se continúa el trabajo desarrollado en la sección correspondiente del 21 Congreso de la Asociación Alemana de Hispanistas en Múnich (2017), que planteó la representación de la diversidad funcional como un primer acercamiento a esta circunstancia (véase Checa/Hartwig 2018). A partir de la base científica y especulativa conformada en esa ocasión, el propósito persigue precisar el enfoque para desarrollar y perfilar un tema todavía casi inexistente en el ámbito de los estudios culturales hispánicos. Le agradezco a Petra Millies-Bald su ayuda con la edición de este volumen y a María Victoria Gómez Gónzalez su ayuda con la revisión lingüística de mis contribuciones a este volumen. 
El volumen tiene dos intereses centrales: analizar la relación (institucionalizada) entre personas con y sin diversidad funcional en los textos culturales (semi)ficcionales a través de los tres términos clave inclusión, integración y diferenciación; y estudiar en los textos concretos cómo se perfilan o incluso se realizan la inclusión, la integración y la diferenciación, y cuáles son las oportunidades que crean y los peligros que corren para el desarrollo de la relación entre personas con y sin diversidad funcional. En cada contribución se plasma también el papel de los estudios culturales en los disability studies. Estudiar la inclusión de personas con diversidad funcional en los contextos estéticos es un eslabón para el estudio de las culturas contemporáneas, cuya cohesión se mide también por su tratamiento de la diversidad funcional. Ravaud/Stiker afirman:

Questions of inclusion versus exclusion of disabled persons cannot be separated from questions relative to the global processes of social cohesion or social dissociation. The way in which a society situates and treats the disabled is not independent for the way in which it constructs social bonds or dissolves them. (Ravaud/Stiker 2001: 490)

Puesto que las experiencias de inclusión no se transmiten ni se comunican en forma de tratados, ${ }^{24}$ hay que buscar maneras de hacerlas sentir a los lectores o espectadores. En este sentido, la literatura, el teatro y el cine disponen tal vez, de posibilidades de influir sobre la sociedad, que un discurso o una convención política no saben alcanzar.

\section{Bibliografía}

Checa, Julio/Hartwig, Susanne (eds.). 2018. ¿Discapacidad? Literatura, teatro y cine hispánicos vistos desde los disability studies, Berlin: Peter Lang.

Corbineau-Hoffmann, Angelika. 2017. Kontextualität. Einführung in eine literaturwissenschaftliche Basiskategorie, Berlin: Erich Schmidt.

Felder, Franziska. 2013. "Inclusion and the Good Human Life", en: Jerome E. Bickenbach/Franziska Felder/Barbara Schmitz (eds.), Disability and the Good Human Life, Cambridge: Cambridge University Press: 300-322, https://www. cambridge.org/core [13-04-2018].

Höhne, Gisela. 1999. "Spiel und Subversivität - das Theater Rambazamba", en: Bernd Ruping (ed.), Theater, Trotz \& Therapie. Ein Lies- und Werkbuch des Theaterpädagogischen Zentrums der Emsländischen Landschaft e. V. und des Studiengangs Theaterpädagogik der Fachhochschule Osnabrück, Standort Lingen, Sögel: Emsländische Landschaft: 75-97.

24 Véanse Nussbaum (1990: 44) y Schildknecht (1996: 42). 
Kastl, Jörg Michael. 2015. "Inklusionsrituale und inklusive Communitas. Paradoxien der Behinderung in der modernen Gesellschaft", en: Robert Gugutzer/Michael Staack (eds.), Körper und Ritual, Wiesbaden: Springer VS: 263-287.

Kastl, Jörg Michael. 2017. Einführung in die Soziologie der Behinderung. Ein Lehrbuch, $2^{\mathrm{a}}$ ed. compl. revis. y aum., Wiesbaden: Springer VS.

Luhmann, Niklas. 1997. Die Gesellschaft der Gesellschaft, Frankfurt a. M.: Suhrkamp.

Malzacher, Florian. 2015. “Introduction”, en: íd. (ed.), Not Just a Mirror. Looking for the Political Theatre of Today, Berlin: Alexander: 11-14.

[Naciones Unidas]. [2006]. "Convención sobre los Derechos de las Personas con Discapacidad y Protocolo Facultativo", en: http://www.un.org/disabilities/ documents/convention/convoptprot-s.pdf [26-09-2018].

Nussbaum, Martha C. 1990. Love's Knowledge. Essays on Philosophy and Literature, New York/Oxford: Oxford University Press.

Parr, Rolf. 2008. "Liminale und andere Übergänge. Theoretische Modellierungen von Grenzzonen, Normalitätsspektren, Schwellen, Übergängen und Zwischenräumen in Literatur- und Kulturwissenschaft", en: Achim Geisenhanslüke/ Georg Mein (eds.), Schriftkultur und Schwellenkunde, Bielefeld: transcript: 1163.

Ravaud, Jean-François/Stiker, Henri-Jacques. 2001. "Inclusion/Exclusion. An analysis of Historical and Cultural Meanings", en: Gary L. Albrecht/Katherine D. Seelman/Michael Bury (eds.), Handbook of Disability Studies, Thousand Oaks/London/New Delhi: Sage: 490-512.

Rösner, Hans-Uwe. 2014. Behindert sein - behindert werden. Texte zu einer dekonstruktiven Ethik der Anerkennung behinderter Menschen, Bielefeld: transcript.

Romañach, Javier/Lobato, Manuel. 2005. "Functional diversity, a new term in the struggle for dignity in the diversity of the human being", en: Independent Living Forum (Spain), https://disability-studies.leeds.ac.uk/wp-content/uploads/ sites/40/library/zavier-Functional-Diversity-Romanach.pdf [26-11-2018].

Schildknecht, Christiane. 1996. "Metaphorische Erkenntnis - Grenze des Propositionalen?", en: Hans Julius Schneider (ed.), Metapher, Kognition, künstliche Intelligenz, München: Fink: 33-52.

Wansing, Gudrun. 2007. "Behinderung: Inklusions- oder Exklusionsfolge? Zur Konstruktion paradoxer Lebensläufe in der modernen Gesellschaft”, en: Anne Waldschmidt/Werner Schneider (eds.), Disability Studies, Kultursoziologie und Soziologie der Behinderung. Erkundungen in einem neuen Forschungsfeld, Bielefeld: transcript: 275-297. 
Wansing, Gudrun. 2014. "Konstruktion - Anerkennung - Problematisierung: Ambivalenzen der Kategorie Behinderung im Kontext von Inklusion und Diversität", en: Soziale Probleme 25 (2): 209-230, http://nbn-resolving.de/ urn:nbn:de:0168-ssoar-447987 [08-11-2018]. 



\section{Inclusión en el escenario}





\title{
Julio Enrique Checa Puerta \\ Universidad Carlos III de Madrid \\ El Festival ÍDEM, la mediación del marco legal entre la producción y la creación artística
}

\begin{abstract}
This chapter proposes a study of the relations between the European and Spanish legislative framework of the last decades in the field of disability and performing arts and its relationship with the performing arts festival IDEM, promoted by La Casa Encendida, de Madrid, between the years 2003 and 2018.
\end{abstract}

Keywords: cultural studies, disability studies, performance, festivals, legislation

En este trabajo me propongo subrayar la estrecha interdependencia que puede establecerse entre las políticas públicas y aquellos proyectos o iniciativas que contribuyen a la promoción de la creación artística, especialmente importante en el caso de prácticas escénicas situadas en los márgenes del sistema cultural hegemónico, en el que, a menudo, los modos de producción y la gestión resultan determinantes para entender tanto los temas como la naturaleza de los lenguajes expresivos. Para ello, quisiera comparar el marco legal español en materia de discapacidad con una iniciativa de programación artística surgida en una de las instituciones culturales más importantes de Madrid, La Casa Encendida: el Festival ÍDEM.

Dentro del ámbito español, de la misma manera que puede considerarse que la Ley Orgánica 3/2007, de 22 de marzo, para la igualdad efectiva de mujeres y hombres, ha marcado un punto de inflexión en lo referido a la visibilización y reconocimiento de la actividad de las mujeres en la esfera pública española, podría pensarse que el Real Decreto Legislativo 1/2013, de 29 de noviembre, ${ }^{1}$ por el que se aprueba el Texto Refundido de la Ley General de derechos de las personas con discapacidad y de su inclusión social, hubiera tenido la virtualidad de promover transformaciones equivalentes. Este decreto, que recoge todo un largo proceso de demandas y de cambios en la legislación, resulta del calado suficiente como para suponer que debiera contribuir decisivamente a la creación de capacidades. Sin duda, una posible certificación de esta hipótesis nos puede venir dada a través de los sistemas de representación artística, que construyen

1 https://www.boe.es/buscar/pdf/2013/BOE-A-2013-12632-consolidado.pdf 
un amplio y potente repertorio de estereotipos e imaginarios sociales, necesarios para evaluar conceptos como normalidad o legitimidad, al tiempo que dan muestras sobre cómo se produce el reparto de lo sensible, y determinan los grados de justicia y decencia de una sociedad, entre algunos de los indicadores más relevantes. Por ello, tomo como eje vertebral de mi trabajo una iniciativa que comenzó en La Casa Encendida de Madrid en el año 2003, en sintonía con la declaración de ese año como "Año Europeo de la Discapacidad", y que se transformaría en el año 2013, coincidiendo con el real decreto arriba señalado. Como veremos, el marco legislativo resultó fundamental para crear una muestra o ciclo, primero; y para transformarlo en un festival, después. Además, las quince ediciones celebradas ofrecen una trayectoria dilatada como para dedicarle atención pormenorizada. Aunque las razones de espacio no me permiten detenerme en un desarrollo más amplio del marco teórico, no creo posible evitar algunas cuestiones previas, como las tesis de Martha Nussbaum, quien sostiene que entre las capacidades centrales del ser humano estarían la posibilidad de usar la imaginación y el pensamiento para la experimentación y la producción de obras y actos religiosos, literarios, musicales o de índole parecida según la propia elección, el uso de la propia mente en condiciones protegidas por las garantías de la libertad de expresión política y artística, y por la libertad de práctica religiosa, así como la posibilidad de disfrutar de experiencias placenteras. Y como advierte Nussbaum, son fundamentales las vías que permitan a todos los individuos funcionar de acuerdo a sus capacidades. Por ello, afirma:

es importante la elección de políticas que protejan y apoyen la agencia (la capacidad de acción del individuo) en vez de otras que infantilicen a las personas y las traten como receptoras pasivas de prestaciones [...] Investigar posibles capacidades/funcionamientos fértiles y desventajas corrosivas ayuda a detectar puntos donde pueden intervenir más adecuadamente las políticas públicas. (Nussbaum 2012: 56)

Esa creación de capacidades va ligada a cómo se establece en una sociedad lo que J. Rancière denomina reparto de lo sensible, pues "revela quién puede tomar parte en lo común en función de lo que él hace, del tiempo y del espacio en los cuales esa actividad se ejerce [...] pues las prácticas artísticas son 'maneras de hacer' que intervienen en la distribución general de las formas de hacer y en sus relaciones con las maneras de ser y las formas de la visibilidad." (Rancière 2014: 20). En última instancia, la creación de capacidades y el reparto equilibrado de lo sensible contribuyen a construir una sociedad decente, esto es, una sociedad que no humilla a sus ciudadanos. Uno de los mecanismos más potentes de humillación es la estigmatización, que consistiría en mirar a los humanos como infrahumanos, no como personas. Así: 
Quienes soportan un estigma aparecen en su entorno como portadores de una etiqueta que les hace parecer menos humanos. Aunque otros los sigan viendo como humanos, son humanos estigmatizados. Erwin Goffman ya hizo ver el prejuicio que ello supone a la identidad social de los estigmatizados [...] Los estigmatizados son vistos como seres humanos, si bien gravemente imperfectos. Es decir, infrahumanos. El estigma denota una grave desviación del estereotipo "apariencia normal" de un ser humano [...] Cuando el estima se apodera de la persona; es decir, cuando ensombrece las características que nos permiten ver al otro como humano hasta tal punto que toda nuestra atención se centra en el hecho de que este sea, por ejemplo, un enano, nuestra mirada se transforma hasta verlo como infrahumano. (Margalit 2010: 90-91)

Aunque me ocuparé del Festival ÍDEM, que pondré en relación con el marco legal en el que surge, es obvio que hay que considerarlo también como resultado de un proceso que arrancaba de finales de los años 70, con la Constitución española de 1978, por un lado; y con el trabajo de pioneras como Maite León o María Fux, por otro. Estos trabajos, surgidos en un momento en que la vida española experimenta el paso de la dictadura a la democracia, tardarían aún algunos años en verse siquiera "acogidos" en la programación de festivales, aunque podemos citar algunos hitos: el Festival Escena Mobile, organizado en Sevilla por la entidad Danza Mobile; o posteriores; el Festival Diez Sentidos en la ciudad de Valencia 2011, cuyo ideario va más allá de la discapacidad, el ya festival de referencia, Una mirada diferente organizado por el INAEM; el Festival de Venagua en Murcia, o el Festival Art Impossible realizado en el Mercat de las Flors en Barcelona.

En síntesis, el interés de estas iniciativas y de otras iniciativas podría expresarse por los siguientes objetivos fundamentales:

- Dar visibilidad a unos modelos representacionales, en el sentido amplio de la palabra, en los que tenga cabida la diversidad.

- Legitimar la ocupación de los espacios escénicos convencionales y normalizar la presencia de artistas que habitualmente quedan fuera del sistema de representación institucional.

- Ofrecer creaciones que cuestionen estereotipos, conceptos (norma/diferencia) y legitimidades (reparto de lo sensible).

- Propiciar espacios de reflexión acerca de lo que se supone sean el arte y el hecho artístico: códigos estéticos, repertorio temático, profesionalismo, virtuosismo, etc.

- Incorporar al hecho artístico a públicos habitualmente no considerados como potenciales destinatarios de diferentes formas de cultura.

Si aceptásemos la posibilidad de que estos objetivos se hubieran cumplido, al menos en parte, quizás la pregunta que conviene formular sería si hubieran sido 
posibles estas iniciativas sin un marco legal que diera cuenta de la necesidad de atender a esta demanda social y cultural o si, más bien, el marco legal viene dado como consecuencia de estas prácticas artísticas que evidencian modelos sociales marginadores e injustos. En el volumen dedicado a hacer balance sobre los 10 años de las Jornadas sobre inclusión social y educación en las Artes escénicas, el actual Ministro de Cultura de España y fundador de la Casa Encendida, José Guirao, afirmaba:

Resulta gratificante comprobar cómo la colaboración entre distintas instituciones ha consolidado un proyecto como este, que puede presumir de haber afianzado en la agenda social de las organizaciones culturales en España la necesidad de reflexionar sobre una gestión inclusiva de la que todos somos responsables. (Guirao 2018: 2)

Sin duda, se trata de una iniciativa de gran alcance en la que, en efecto, colaboran instituciones de ámbito nacional y local, como Casa Encendida de la Fundación Montemadrid, la asociación Red Española de Teatros Auditorios y Circuitos de Titularidad Pública, la Agencia Andaluza de Instituciones Culturales de la Junta de Andalucía, el Institut del Teatre de la Diputación de Barcelona, la Real Escuela Superior de Arte Dramático de Madrid (RESAD), el Teatro Rosalía Castro de A Coruña, el Teatro Gayarre de Pamplona, o el Teatro Circo de Murcia. La gestora fundamental de este proyecto, también responsable de ÍDEM, como ya hemos señalado, Paz Santa Cecilia, afirmaba que el propósito de la primera jornada, impulsada por el British Council consistió en ofrecer una amplia visión del panorama actual de la inclusión social y la educación en las áreas de teatro, música y danza en España y en Gran Bretaña, al tiempo que se pretendía favorecer el intercambio y facilitar la adopción de buenas prácticas y la aplicación de políticas y proyectos referidos a las artes escénicas que favorecieran la inclusión social, la integración de comunidades, la educación y el desarrollo de nuevas audiencias. No creo que sea sorprendente el balance que hacía sobre la situación en el año 2009:

- Mientras que los expertos británicos, además de llevarnos años de ventaja en la práctica, son capaces de trasladar y comunicar de manera eficaz su trabajo; los expertos españoles, a pesar de estar desarrollando iniciativas igual de interesantes, aún no han encontrado la manera de compartirlas y comunicarlas.

- Se trabaja con gran precariedad (de recursos, de vínculos, de reconocimiento...) y casi en la clandestinidad, circunstancias que fomentan el intrusismo profesional bienintencionado y contraproducente.

- Existe un gran desconocimiento y, por lo tanto, desconexión entre las iniciativas en marcha, los distintos colectivos, las instituciones y los profesionales artísticos. 
- No hay tiempo para formarse, reciclarse o reflexionar sobre lo que hacemos y cómo lo hacemos.

- Apenas existen referencias artísticas nacionales, por lo que se hace necesario ampliar el imaginario del sector, contribuir a inspirar y fomentar la creación artística con colectivos en riesgo de exclusión y crear las plataformas para visibilizarla (Santa Cecilia 2018: 19).

En mi opinión, a la hora de hacer un análisis sobre cómo funciona el modelo representacional, el sistema de producción y de exhibición y en qué medida ha podido verse determinado por los cambios legislativos, o por las modificaciones de los horizontes de expectativas, se podrían tomar en consideración algunos parámetros, a modo de decálogo, entre los que se incluirían:

1. Las fechas de programación. Es importante considerar que los momentos más bajos de las temporadas suelen concentrarse entre finales del mes de mayo y finales de septiembre.

2. Los espacios destinados a la representación, si son convencionales o no, si son las salas grandes o pequeñas de los espacios de titularidad pública, etc.

3. Si se exhiben espectáculos exentos, o si forman parte de la programación de ciclos, muestras, jornadas o festivales. En este caso, conviene valorar cuál es la naturaleza de esos festivales y la visibilización real que permiten a cada uno de los trabajos.

4. Si gozan de algún tipo de subvención, o puede accederse libremente a los espectáculos. En todo caso, el precio de las localidades también puede considerarse un elemento importante.

5. Si van destinados a públicos específicos, sobre todo cuando se parte de la posibilidad de "admitir" códigos de conducta no convencionales.

6. Qué tipo de lenguajes predominan y cuál es la estructura o la dramaturgia de los espectáculos.

7. Cómo funcionan los dispositivos escénicos en materia de escenografía, utilería, vestuario, diseño de luz y sonidos, etc.

8. Cómo están conformados los elencos, si son reducidos o numerosos, profesionales o aficionados, etc.

9. Cuál es la atención que les dispensa a los espectáculos o festivales la prensa especializada, así como la prensa diaria en sus páginas o suplementos culturales. ¿Qué es lo que se destaca de las compañías y de sus intérpretes?

10. Cuáles son los ámbitos geográficos de procedencia de las compañías, y cuál es su naturaleza: mixta o uniforme, etc. ¿Quién actúa como portavoz? 
De este modo, propondría tomar en consideración, al menos, estos elementos indicadores, para valorar si el diagnóstico ofrecido por Paz Santa Cecilia, una de las principales gestoras del ámbito escénico español, se puede considerar aún vigente. No se me escapa que sería fundamental también hablar de la calidad estética o artística de los proyectos analizados, pero eso abriría otro frente de análisis que, en cierto modo, se puede reconocer a partir de la selección propuesta. No obstante, dejo para otro trabajo el análisis más pormenorizado de los trabajos ofrecidos en este festival y ofrezco enlaces a grabaciones de muchos de ellos, de modo que quienes se acerquen a este ensayo tengan ocasión de valorar por su propia cuenta los trabajos reseñados. Y, en todo caso, parto de la hipótesis de que los cambios legislativos han contribuido en buena medida a propiciar un marco diferente dentro de la industria cultural y, como poco, se han hecho eco de algunas de las demandas que implícita o explícitamente se podrían reconocer en muchas de las propuestas artísticas. Hasta qué punto se trate de logros ya consolidados, o no, lo dejaré para las conclusiones.

Quizás no esté de más recordar la Ley 13/1982, de 7 de abril, de integración social de los minusválidos. ${ }^{2}$ En ella se hablaba ya de la necesidad de integrar socialmente a los "disminuidos en sus capacidades físicas, psíquicas o sensoriales, y a los disminuidos profundos para la asistencia y tutela necesarias." Al tiempo, se anunciaba una legislación "para la integración social de los disminuidos en la declaración de derechos del deficiente mental", aprobada por las Naciones Unidas el 20 de diciembre de 1971. Por último, se consideraba una "obligación del Estado la prevención, los cuidados médicos y psicológicos, la rehabilitación adecuada, la educación, la orientación, la integración laboral, la garantía de unos derechos económicos, jurídicos sociales mínimos y la Seguridad Social." En dicha Ley, se entenderá por minusválida "toda persona cuyas posibilidades de integración educativa, laboral o social se hallen disminuidos como consecuencia de una deficiencia, previsiblemente permanente, de carácter congénito o no, en sus capacidades físicas, psíquicas o sensoriales." La Cultura, más bien las actividades culturales, se integra dentro de los Servicios Sociales, como mecanismo que permita, al igual que sucede con la Educación, la superación de las deficiencias. Casi doce años más tarde, en 1994, la Asamblea General de las Naciones Unidas aprobaría las Normas Uniformes sobre la igualdad de oportunidades para las personas con discapacidad. Resulta interesante reconocer que se inspiraban en el movimiento surgido a finales de los años 60, en el que se reclamaba la necesidad de formular un nuevo concepto de discapacidad. Como

2 https://boe.es/buscar/pdf/1982/BOE-A-1982-9983-consolidado.pdf 
han señalado algunos análisis, existía la demanda de elaborar una doctrina que se basara en el reconocimiento de los derechos de las personas con discapacidad y la necesidad de diferenciar los términos "discapacidad" y "minusvalía", pues se utilizaban con cierta imprecisión. Parece evidente que la terminología reflejaba un enfoque médico y de diagnóstico que hacía caso omiso de las imperfecciones y deficiencias de la sociedad circundante, todo esto a pesar de que la OMS había aprobado en 1980 una Clasificación Internacional de Deficiencias, Discapacidades y Minusvalías, que sugería un enfoque más preciso y, al mismo tiempo, relativista. Resultaba imprescindible atender a las necesidades de los individuos (como rehabilitación y recursos técnicos auxiliares), pero también a las deficiencias de la sociedad (diversos obstáculos para la participación).

Llegados al año 2001, el Consejo de Europa decide, el 3 de diciembre de 2001, declarar el año 2003 como el Año Europeo de las Personas con Discapacidad. Se amparaban en iniciativas anteriores (años 1990, 1996 y 1999), sobre todo, en las Conclusiones del Consejo Europeo de Lisboa, celebrado en marzo de 2000, en las que se invitaba a los Estados miembros a implantar medidas que evitasen la exclusión social, a través de políticas sociales y de empleo, entre otras. De este modo, la declaración del Año Europeo podría contribuir poderosamente a avanzar en esta dirección. De este modo, el proyecto del Festival de Artes Escénicas puesto en marcha por La Casa Encendida arrancaría en sintonía con esta iniciativa comunitaria. También en ese mismo año 2001 se promulgaría en España el Real Decreto 946/2001, de 3 de agosto, ${ }^{3}$ por el que se aprobó el Estatuto del Real Patronato sobre Discapacidad. En él, se hacía un interesante un repaso de la legislación española en materia de discapacidad. Aquí destacaría la Ley 14/2000 de Medidas fiscales, administrativas y del orden Social, ${ }^{4}$ mediante la cual se crea el Real Patronato sobre Discapacidad, cuyas funciones son: promover la aplicación de los ideales humanísticos, los conocimientos científicos y los desarrollos técnicos al perfeccionamiento de las acciones públicas y privadas sobre Discapacidad, etc. Todas estas medidas tendrán importantes consecuencias en el ámbito de la discapacidad en España, como son la promoción de la perspectiva de los Derechos Humanos, el impulso de la investigación y difusión de publicaciones o la creación del Centro de Normalización Lingüística de la Lengua de Signos Española, o el Centro Español del Subtitulado y la Audiodescripción.

Dos años más tarde, en 2003, se aprobaría la Ley 51/2003, de 2 de diciembre, de Igualdad de oportunidades, no discriminación y accesibilidad universal de las

3 https://www.boe.es/buscar/pdf/2001/BOE-A-2001-17026-consolidado.pdf

4 https://boe.es/boe/dias/2000/12/30/pdfs/A46631-46723.pdf 
personas con discapacidad. ${ }^{5}$ En esta ley se reconocía la existencia de unos 3.5 millones de personas con alguna discapacidad en España y la necesidad de que todas pudieran "participar en igualdad de condiciones que el resto de ciudadanos en la vida económica, social y cultural del país." Probablemente, es la primera vez que la palabra "cultura" aparecía citada expresamente en estos textos legales. En este sentido, el texto se refiere también a un nuevo enfoque, que se orienta, sin citarla, hacia la inclusión. Todo su desarrollo se completa con una definición del término discapacidad: "Son personas con discapacidad aquellas que presenten deficiencias físicas, mentales, intelectuales o sensoriales a largo plazo que, al interactuar con diversas barreras, puedan impedir su participación plena y efectiva en la sociedad, en igualdad de condiciones con los demás." También aquí será donde se indica el grado de discapacidad igual o superior al 33\% para ser necesaria la aplicación de las medidas previstas de ayuda o atención especial. Por último, se declara el Consejo Nacional de la Discapacidad como un órgano colegiado interministerial de carácter consultivo, adscrito al Ministerio de Trabajo y Asuntos Sociales. Asimismo, se considera al Observatorio Estatal de la Discapacidad como un instrumento técnico de la Administración General del Estado que, a través de la Dirección General de Coordinación de Políticas Sectoriales sobre la Discapacidad del Ministerio de Sanidad, Política Social e Igualdad, se encarga de la recopilación, sistematización, actualización, generación de información y difusión relacionada con el ámbito de la discapacidad.

En el año 2007, se promulga la Ley 27/2007, de 23 de octubre, ${ }^{6}$ por la que se reconocen las lenguas de signos españolas y se regulan los medios de apoyo a la comunicación oral de las personas sordas, con discapacidad auditiva y sordociegas. También en ese mismo año se promulga la Ley 49/2007, de 26 de diciembre, ${ }^{7}$ por la que se establece el régimen de infracciones y sanciones en materia de igualdad de oportunidades, no discriminación y accesibilidad universal de las personas con discapacidad; y un año más tarde, en 2008, se publica la Orden CUL/3520/2008 de 1 de diciembre, por la que se aprueba el Código de buenas prácticas del Instituto Nacional de las Artes Escénicas y de la Música. ${ }^{8} \mathrm{Al}$ año siguiente se pondrían en marcha las Jornadas sobre la Inclusión Social y la Educación en las Artes Escénicas (2009), pero apenas hay nada sobre la incorporación de intérpretes con discapacidad a ninguna de las unidades de producción del INAEM, por ejemplo.

5 https://www.boe.es/buscar/pdf/2003/BOE-A-2003-22066-consolidado.pdf

6 https://www.boe.es/boe/dias/2007/10/24/pdfs/A43251-43259.pdf

7 https://www.boe.es/boe/dias/2007/12/27/pdfs/A53278-53284.pdf

8 https://www.boe.es/buscar/pdf/2008/BOE-A-2008-19644-consolidado.pdf 
Así llegamos al año 2010, en el que se promulgará el Real Decreto 497/2010, de 30 de abril, por el que se regulan los Órganos de participación y asesoramiento del Instituto Nacional de las Artes Escénicas y de la Música; ${ }^{9}$ y un año más tarde, se promulgaría la Ley 26/2011, de 1 de agosto, de adaptación normativa a la Convención Internacional sobre los Derechos de las Personas con Discapacidad, ${ }^{10}$ que fueron aprobados el 13 de diciembre de 2006 por la Asamblea General de las Naciones Unidas.

Tras este recorrido, el año central para lo que nos ocupa será el año 2013, en el que aparece el Real Decreto Legislativo 1/2013, de 29 de noviembre, por el que se aprueba el texto refundido de la Ley General de derechos de las personas con discapacidad y su inclusión social. ${ }^{11}$ Como veremos, este es, en parte, el título de las Jornadas organizadas por el INAEM y, sobre todo, merece la pena consignar que será en 2013 cuando el INAEM ponga en marcha el Festival Una mirada diferente. También será el año en que el Festival sobre Artes Escénicas e Inclusión de la Casa Encendida, después de 10 ediciones, pase a llamarse Festival ÍDEM. Festival de Artes Escénicas e Inclusión Social.

Es muy importante que en esta ley se defina la "discapacidad" como "una situación que resulta de la interacción entre las personas con deficiencias previsiblemente permanentes y cualquier tipo de barreras que limiten o impidan su participación plena y efectiva en la sociedad, en igualdad de condiciones con las demás." También es muy importante que se insista en la dimensión cultural como uno de los objetivos de la ley, junto a los ámbitos político, económico, social, laboral, etc. Como puede verse, el impulso que supuso la decisión del año 2001 para declarar el año 2003, Año Europeo, abrió un evidente cambio de perspectiva en la legislación europea y española, que se vio acompañado, en el ámbito de las artes escénicas, por las iniciativas que estamos considerando, a saber, el Festival de Artes Escénicas y Discapacidad, el Festival ÍDEM.

En su primera edición, la del año 2003, se anunció como ciclo, dentro de la programación de Artes Escénicas de La Casa Encendida, estimulado por la declaración de 2003 como Año Europeo de la Discapacidad. Este ciclo, en algún lugar denominado "muestra", no disponía de una publicidad específica y tenía un formato muy modesto; no así lo eran sus objetivos: "Nuestro fin es actuar en favor de la sensibilización de la opinión pública, la promoción de medios de igualdad y la mejora de la imagen positiva de las personas con discapacidad,

9 https://www.boe.es/buscar/pdf/2010/BOE-A-2010-8122-consolidado.pdf

10 https://boe.es/buscar/pdf/2011/BOE-A-2011-13241-consolidado.pdf

11 https://boe.es/boe/dias/2013/12/03/pdfs/BOE-A-2013-12632.pdf 
mostrando la heterogeneidad de la discapacidad y sus múltiples manifestaciones." ${ }^{12}$ En esta edición se programaron, como sería práctica frecuente a lo largo de todas las ediciones, tres espectáculos: Psicoballet de Maite León; L’Image, de la Cía. Danza Mobile ${ }^{13}$, y Los habitantes de Urano, de la Cía. El Tinglao. Todavía en la edición de 2004, siguió la denominación de lo que sería el II Ciclo de Artes Escénicas y Discapacidad, y se ofrecieron otros tres espectáculos, anunciados dentro de la programación de septiembre de artes escénicas de La Casa Encendida: El rey pescador, de la Cía. Flick Flock Danza; Dancer’s Syndrome, de la Cía. Stopgap Dance, y Psicoballet de Maite León.

La edición de 2005 se presentó ya como Festival Artes escénicas y discapacidad, III Edición, y no solo pasó a denominarse festival, sino que contó ya con un programa de mano propio, exento. Se ofrecieron los siguientes espectáculos: Fando y Lis, de Fernando Arrabal, por la Cía. El Tinglao, Ahora fobia, de la Cía. Contando Hormigas, y Et six Gisèle?, de la Cía L’Oiseau-Mouche. ${ }^{14}$ Por su parte, la edición de 2006 contaría con cuatro espectáculos programados: Desde lo invisible, de la Cía. Quintana teatro; Jaquelado ${ }^{15}$ de la Cía. Danza Mobile; Producto Interior Bruto, de la Cía Rizoma Teatro ${ }^{16}$ y En Blanco, de Patricia Ruz. ${ }^{17}$

La edición de 2007 volvió a contar únicamente con tres espectáculos: Delicious, de la Cía StopGap Dance Company; Mañana voy yo difícil, de la Cía. Contando Hormigas ${ }^{18}$ y Sencity y música electrónica, propuesta de la compañía Skyway Foundation. ${ }^{19}$

También serían 3 los espectáculos programados en 2008: La retina transparente, de la Cía. Contando Hormigas; El encuentro, de Laura Scudella y Juri Roverato, ${ }^{20}$ y Un rico, tres pobres, de la Cía. Théâtre du Cristal. ${ }^{21}$ Esta será la misma estructura que encontraremos en la edición de 2009, con los espectáculos

12 Todas estas citas se recogen de diferentes notas de prensa publicadas en la página web de La Casa Encendida (https://www.lacasaencendida.es), y en los programas de mano de los espectáculos y de la publicidad mensual de la institución.

13 Limage: https://www.youtube.com/watch?v=5gyp3rGyRaI

14 http://oiseau-mouche.org

15 Jaquelado: https://www.youtube.com/watch?v=p1Q-eMpIgeU

16 PIB: https://www.youtube.com/watch?v=nKdxzzk93Vk

17 En Blanco: https://vimeo.com/191961356

18 Mañana voy yo difícil: https://www.youtube.com/watch?v=YK4CUZiB_uM

19 Skyway Foundation: https://www.youtube.com/watch?v=mB0zPcUudXs

20 El encuentro: https://www.youtube.com/watch?v=VIkDaiczSOI

21 Un riche, trois pauvres: https://www.youtube.com/watch? $\mathrm{v}=\mathrm{eXD} 2 \mathrm{Ayb} 2 \_\mathrm{w}$ 
Genius + Unexplotet stories, de la Cía. Anjali Dance Company; ${ }^{22}$ Pez y Pescado, de la Cía. Röthlisberger y Danza Mobile; ${ }^{23}$ y Alter Ego, de la Cía. Así Somos. ${ }^{24}$

Para la edición de 2010, el festival se planteaba atender al concepto de Diferencia, y se conformó un programa en el que se reunieron los espectáculos: ALI, de la Cía. Les mains les pieds et la tête aussi; ${ }^{25}$ Cocktail, de la Cía. Treceacero, y Beautiful People, de Rui Horta y el grupo Dançando com a Diferença. ${ }^{26}$

La edición de 2011 subrayó la orientación del año anterior y contó con cuatro compañías profesionales que trabajan sobre el concepto de diferencia. De este modo, se programaron los espectáculos Et puis jai demandé a Christian de jouer l'intro de Ziggy Stardust, de la Cía A Glam Project/Renaud Cojo/Ouvre le chien; ${ }^{27}$ The Encounters: lodgers, de la Cía. Introdans y el Centro Dr. Leo Kannerhuis; ${ }^{28}$ Submerge, de la Cía. Indepen-Dance, ${ }^{29}$ y Heroica 3, de la Cía. Lisarco Danza. ${ }^{30}$

En la presentación de la edición del año 2012, se expresó de forma explícita el término "inclusión". Los espectáculos programados fueron Las visiones de Hildegard, de la Cía Contando Hormigas, ${ }^{31}$ Sombras de amor prohibido, de la Cía. Orozú Teatro, ${ }^{32}$ Noah, de la Cía. Locos por el Teatro, ${ }^{33}$ y Sorda, de Ma Ángeles Narváez, La niña de los cupones. ${ }^{34}$

La edición del año 2013 coincidió prácticamente con la aprobación del Real Decreto Legislativo 1/2013, y según se hacía constar en la publicidad, el denominado Festival de Artes Escénicas e Inclusión Social (ÍDEM), organizado por la Casa Encendida de la Fundación Especial Caja Madrid, recogía la herencia del ciclo Artes Escénicas y Discapacidad, que la misma institución había celebrado durante los últimos diez años y que, en esta edición, ampliaba su oferta cultural con nuevas actividades de artistas internacionales como el teatro, la danza, la música y el cine. En esta edición, se programaron trabajos de Bill Shannon en

22 Genius: https://www.youtube.com/watch?v=u9tj5QVvhaw

23 Pez y Pescado: https://www.youtube.com/watch?v=KkqyIuOVvT0

24 Video de promoción de la asociación ASSIDO: https://www.youtube.com/watch? $\mathrm{v}=\mathrm{i}$ FSOIakF--4

25 ALI: http://www.lafilature.org/spectacle/nous-sommes-pareils-a-ces-crapauds-qui-ali/

26 Beautiful People: https://www.youtube.com/watch?v=-p-7bB_XWaA

27 Fragmento del espectáculo: https://www.youtube.com/watch?v=gy3bZmd_IrY

28 Reportaje explicativo: https://www.youtube.com/watch?v=5V6uUEborUk

29 http://indepen-dance.org.uk

30 Heroica 3: https://www.youtube.com/watch?v=80kbjomCIt0

31 Las visiones de Hildegard: https:/www.youtube.com/watch?v=98QXbUzj3bY

32 Sombras de amor prohibido: https://www.youtube.com/watch? $v=i l-p y a 4 E v r g$

33 Noah: https://www.youtube.com/watch?reload=9\&v=G-5vg0_lJ50

34 Sorda: https://www.youtube.com/watch?v=E9DvtmiPoIE 
la madrileña plaza de Lavapiés; ${ }^{35}$ Resistir hasta la sombra, de la compañía L'Oiseau-Mouche; ${ }^{36}$ la película Frontera, de Manuel Pérez; ${ }^{37}$ el Concierto MS ME, Genie Cosmas y Ricky Brusco; el espectáculo El primer baile, de Teatro de los Sentidos, Colombia/España; ${ }^{38}$ las películas Mofetas, de Inés Enciso y El viaje de Said, de Coke Riobóo; más el espectáculo Quijotadas, de la compañía Mirage. ${ }^{39}$

En la edición de 2014, el festival se proponía ofrecer espectáculos que abordasen tanto el mundo de la discapacidad como el de la marginación social. Los primeros días se concentraron en la representación de la marginación, con trabajos como la propuesta de danza de Ali Thabet \& Hèdi Thabet, Rayahzone, o la película Blind Fortuin, de Ramon Gieling. Complementaron esta programación otras propuestas, como el espectáculo-taller Las muchas, de Mariantonia Oliver, o la proyección de la película Prohibido recordar, de Josu Martinez y Txaber Larreategi, más la performance O estado salvaxe, de Pablo Fidalgo. Además, se propusieron diferentes creaciones que mostraban la integración social en el ámbito de la diversidad funcional. Así, se programaron cortometrajes como Inocente de Pablo Pastor; y los espectáculos Synergyde la compañía Lisarco, y Las niñas no deberían jugar al fútbol, de La Trastienda. Cerraría la programación un concierto de música de Guinea Conakry a cargo del grupo Sonidos de la tierra.

La edición del año 2015 se abriría con la proyección cinematográfica de Le Conte Des Sables D’Or, de Sam y Fred Guillaume, a la que seguiría el espectáculo Pinocho, ligeramente distinto", de la Compañía Virgilio Sieni, más el montaje de danza Mesa para Tr3s, de Fritsch Company, Danza Contemporánea Inclusiva Madrid. ${ }^{40}$

La edición de 2016 dio comienzo con el espectáculo de percusión Bailar el agua, de Chefa Alonso, ${ }^{41}$ seguido de la propuesta CECI 3.0, de Ferran Orobitg; ${ }^{42}$ más el espectáculo Lucrecia \& Judith, de la compañía Palmyra Teatro. ${ }^{43}$

Para la edición de 2017 se consideraba cómo la evolución de la propia sociedad y las demandas de un público cada vez más concienciado, exigente y comprometido, hicieron necesarios nuevos matices y la apertura a nuevas disciplinas

35 http://www.crutchdoc.com

36 http://www.oiseau-mouche.org

37 http://www.fronteralapelicula.com

38 www.teatrodelossentidos.com

39 http://mirageteatro.wix.com/mirage\#

40 https://vimeo.com/channels/psicoballet/156075555.

41 https://bailarelagua.wixsite.com/inclusion/la-compania

42 https://youtu.be/0XII-coWlb4

43 http://canalperucultural.blogspot.com/2016/10/teatro-lucrecia-y-judith.html 
y a otros ámbitos de exclusión social. Por este motivo, en esta edición, ÍDEM reunió una serie de piezas que hablan de inmigración, islamofobia, justicia o capacidad vs. discapacidad, etc. Los espectáculos programados fueron Awake. Cheer up... Armageddon's coming! deMichael Achtman; Mos Maiorum o las costumbres de los ancestros de Ireneu Tranis, Alba Valldaura y Mariona Naudín. ${ }^{44}$

Para la edición de 2018, el catálogo temático ya abarcaba asuntos como la enfermedad mental, las personas refugiadas, la discapacidad, la memoria o la igualdad de género, y se ofreció la propuesta Disten(se)sion, en la que se permitía la opción de entrar y salir libremente del espectáculo, de hablar, de moverse e, incluso, de incorporarse a la pieza. Disten(se)sion pretendía fomentar la creación y la investigación artística dirigida a personas con diversidad funcional severa para que tuvieran acceso a las artes vivas en condiciones de excelencia artística, así como promover su asistencia a espectáculos en los que pudieran compartir experiencias estéticas con sus acompañantes sin el estrés que produce no poder ajustarse a los códigos de comportamiento establecidos. Entre las propuestas, se incluyó el espectáculo Happy Island de La Ribot con la compañía Dançando com a Diferença ${ }^{45}$ la proyección fílmica L’artiste des mots de Maxime Huyghe; el espectáculo Anguilas De la compañía Andrés Cavallín, y el documental ¿Y si te dijeran que puedes? De Javier Álvaro.

$\mathrm{Si}$ atendemos al decálogo al que nos referíamos al comienzo de este trabajo, conviene considerar que este festival siempre se ha programado en septiembre, coincidiendo con lo que podría considerarse el arranque de la temporada teatral en Madrid. El espacio, de manera regular, ha sido el de la institución de acogida, La Casa Encendida, así como algunos espacios públicos aledaños. Por su naturaleza, el festival siempre ha acogido espectáculos determinados por el concepto de la discapacidad, primero, y de la diversidad y la inclusión, después. Todos los espectáculos se presentan independientes, pero dentro de una programación conjunta. El precio de las entradas es muy económico, desde la entrada libre hasta el pago de entre 3 y 5 euros por función. Algunas de las propuestas han ido dirigidas, sobre todo en las últimas ediciones, a públicos con discapacidad severa, lo cual resulta muy interesante desde el punto de vista también de los códigos de conducta. En todos los casos, se ha atendido a la accesibilidad en un amplio sentido (audiodescripciones, lenguaje fácil, etc.). Asimismo, parece incontestable el predominio de trabajos de danza, a menudo con estructuras fragmentadas, lo que no significa que no se hayan ofrecido algunos trabajos de

44 https://vimeo.com/151763118

45 https://youtu.be/f27_G0cESBE 
texto, multidisciplinares o de dramaturgias más convencionales. También es preciso subrayar la atención a muy diferentes expresiones de la diversidad funcional, tanto en los contenidos, como en los elencos de las compañías. Algunos de estos trabajos ofrecen una calidad que puede reconocerse como "de excelencia" y resultan perfectamente homologables dentro del circuito artístico profesional. No obstante, hay numerosos espectáculos que ofrecen escasa envergadura en la puesta en escena. Puede entenderse como un rasgo característico de los lenguajes empleados, pero también de la posible precariedad de medios disponibles. A menudo encontramos elencos muy numerosos, lo que, en términos generales, suele indicar no profesionalismo, dado el coste de cada representación. Tampoco resulta infrecuente la fórmula de una dirección profesional, sin discapacidad, que trabaja con elencos de intérpretes con discapacidad o mixtos. Tal vez por ello, pero no solo, sigue siendo muy escasa la cobertura en las páginas de la prensa periódica y, a menudo, se ofrece la información general sobre el Festival, pero rara vez se encuentra la crítica de alguno de los espectáculos. Además, podría decirse que, entre las compañías invitadas, las que proceden de países europeos presentan un mayor nivel de profesionalismo y, a menudo, las producciones resultan más sofisticadas. Algunas de estas compañías exhiben sus trabajos en grandes festivales reconocidos, como el Festival de Avignon -la compañía L'Oiseau-Mouche-, o el Festival de Otoño de Madrid -la Compañía Stopgap Dance Company, The enormous room-. Asimismo, hay ya trayectorias de compañías españolas suficientemente consolidadas que, sin embargo, apenas traspasan su reconocimiento público fuera del ámbito de la discapacidad, como sucedería con Danza Mobile, al tiempo que son todavía muy frecuentes los trabajos -y las compañías-, que surgen de talleres y encuentros, cuya duración suele ser efímera o muy difícil de mantener. También se puede hablar de una interesante evolución de los lenguajes y de búsqueda de espectáculos de mayor complejidad, que aborden diferentes aspectos al margen de la cuestión asistencial o del motivo de la superación, como serían la sexualidad, el deseo, la memoria o el envejecimiento. En este sentido, muchas propuestas prescinden del estigma, es decir, no ponen delante del espectador la condición como discapacitados de los intérpretes y, en muchas ocasiones, los elencos presentan una conformación que cuestiona los estereotipos y rompen las expectativas. Progresivamente, los espectáculos van alejándose de una etiqueta que los relaciona específicamente con la discapacidad, y se van integrando en dispositivos que se relacionan con diferentes circunstancias vinculadas a la exclusión: inmigración, vejez, refugio, etc. De la misma manera, las artes escénicas dialogan, cada vez más, con lenguajes expresivos que descansan en la práctica audiovisual, el documental o el videoarte. 
Tras este sucinto recorrido, podemos ver cómo desde 1982 -debe tenerse en cuenta que el INAEM se crea en 1985-, hasta el 2013, se fueron implementando una serie de leyes y decretos que, por un lado, adecuaban el marco legal español a las principales tendencias internacionales, especialmente europeas, cuyas políticas públicas recogían cambios en la terminología (minusválidos, impedidos, discapacitados), en la definición (problema individual > relación con el entorno), en los objetivos (sanitarios $>$ asistenciales $>$ derechos, capacidades y justicia), y en los medios y ámbitos de acción (sensibilización, cultura, educación, participación, etc.). De la misma manera, las prácticas escénicas, tal y como se fueron recogiendo a lo largo del mismo período fueron experimentando sucesivas transformaciones, que partieron de un marcado carácter terapéutico y asistencial, hacia proyectos profesionales con la aspiración de homologarse, a todos los niveles, a los que se encontraban en los escenarios convencionales. Por esto, el Festival ÍDEM puede considerarse un ejemplo paradigmático para entender esta relación entre legislación, políticas públicas y creación escénica en el ámbito de la discapacidad.

\section{Bibliografía}

Guirao, José. 2018. Jornadas sobre inclusión social y educación en las Artes escénicas, Madrid: INAEM.

Margalit, Avishai. 2010. La sociedad decente, Barcelona: Paidós.

Nussbaum, Martha. 2012. Crear capacidades. Propuesta para el desarrollo humano, Barcelona: Paidós.

Rancière, Jacques. 2014. El reparto de lo sensible, Buenos Aires: Prometeo Libros.

Santa Cecilia, Paz. 2018. "Introducción”, en: Jornadas sobre inclusión social y educación en las Artes escénicas, Madrid: INAEM: 19-2. 



\title{
David Ojeda Abolafia \\ Real Escuela Superior de Arte Dramático Madrid \\ La metaescena: la inclusión artística y la accesibilidad espectacular
}

\begin{abstract}
The intention of this text is to show the spectacular creative potentiality at the time of attending the possibility to accessibility in artistic enunciation. Also, the ethical reason for the legitimation of political practice which comes before the lack of accessibility on the culture show of people with disabilities because of the common lack for spectacular accessibility. "Metaescena" has the intention to propose like a new category from spectacular analysis, that value like a genuine manifestation starting from aesthetic, artistic and creative work of the performance, the functional diversity like a self-referential and autopoetic body and the dramaturgical-narrative look from the attention of accessibility by the artistic direction. Hopefully, it will continue to increase and taking hold this imprint to be possible a more equal and advanced society which grants growing possibilities and cultural access with the same garanties and guarantees. Reasons that focus on making usual and everyday, but not extraordinary the presence of a diverse plate and an inclusive scene to achieve a total culture in liberty to every person who is part of their society.
\end{abstract}

Keywords: inclusion, accessibility, disability, diversity, scenic arts

\section{La creación escénica y espectacular desde la diversidad}

La creación espectacular, desde la participación de las personas con discapacidad o con diversidad funcional, ha sido una de las apuestas renovadoras de la escena mundial en los últimos cincuenta años. El avance en la consideración de la capacidad como una posibilidad o potencialidad en la condición humana, sin

1 "Mataescena" is born as a possibility of the analyticand narrative spectacular context knowing the analysis and creation that I have been making from my artistic beginning with my actual company Palmyra Teatro. It is linked with different thoughts and concepts that I have been teaching in masterly classes in a master programme: Creation Contemporany master in Carlos III University and Cultural management in Complutense University, both in Madrid.

The article that I quote in this document, meets this thought, and I thank the organization Canis Majoris Foundation in an edition with some authors from the I Journaly Theatre and Social Change that were developed in their headquarters in Madrid in December 2017. I appreciate Rosa Puga for all her attention in this edition and her invitation to the journey 
paragón, y ubicada en la destreza y habilidad para mostrar un aporte genuino a la investigación, la creación y la ampliación de cauces artísticos en la escena y el universo espectacular, se ha labrado a fuerza de la presencia y participación artística de proyectos que han considerado la diferencia en el cuerpo, en la matización personal de la apuesta emocional y en el propósito de vínculo perceptivo-sensorial distinto como canales primordiales creativos a la hora de hallar una ampliación del arte escénico en sus referentes espectaculares.

Desde finales de los años 70, la aparición de las personas con discapacidad en la escena se ha consolidado. El cuerpo en su dimensión plástica y creativa se convertía en un acicate escénico, estético, dando una visión novedosa e increíble a la creación espectacular.

La valoración del aporte de la desmesura o la especial presencia hacía que la categoría artística entrase a debate, sin saber medir cuál podría ser su proporción, si la eficacia realizada a partir de una técnica consabida o la significación de la impronta humana en el registro y repertorio de la presencia de la persona, como artista, y su conformación de acto espectacular en sí. Los distintos apelativos posibles que se consolidaron para calificar este acto manifiesto han sido desde entonces de lo más variopinto: diversidad artística, capacidad diversa, cuerpos diversos, distinta capacidad, integración artística, y finalmente, la inclusión escénica, actual.

La aparición del signo espectacular afincado en el referente humano presente ha hecho palpable la posibilidad de los espectáculos donde participan las personas con discapacidad. El cuerpo en su característica infinita y específica, por qué no estilizada en su peyorativa subjetividad en presencia, hace que se valore la atención al aprendizaje como algo conveniente pero no primordial.

La consabida ampliación de categorías en el arte del espectáculo que supuso la aparición del performance, en su impronta de la realidad y la fisicalidad, así como sus vínculos y diálogos con las otras artes contaminantes, ha sido el camino conveniente e innovador, si bien no el único; pero desde el que se ha logrado abrir espacios a la creación y a la recepción. Con ello, se ha dado la posibilidad de que la diversidad como razón de contingencia física, intelectual y sensorial haya trasformado la convención espectacular como hasta ahora no se había posibilitado.

Desde la Vanguardia, la ampliación del garante humano en su presencia y en su presente ha validado el referente espectacular. La estilización artística se trastoca con el abandono de lo monstruoso, lo horrible, lo inhumano de las visiones finiseculares del siglo XIX en la vertiente "Freaks", para convertirse en impronta portentosa a la hora de hacer valer las características propias como referente identitario espectacular. Esta circunstancia ha abierto miras novedosas, apuestas innovadoras y respuestas increíbles en la escena de los últimos decenios, y como 
consecuencia, la mirada del público, desde la que se debiera permitir su consolidación y afianzamiento.

En esta etapa inicial, la presencia en sí misma cubría la historiografía del espectáculo. El puro devenir del cuerpo que se encarnaba desde su propia prosodia creativa y artística, deshacía cualquier intento o evolución plausible en vincularlo a la técnica o al aprendizaje. Se estimó que solo la participación hacía formidable el acto en sí, el andamiaje de la diferencia humana supuso el signo suficiente para establecer un contingente hecho espectacular, mediado por las formas, sujeto a las agraciadas posibilidades del error conducido o bien por hallar el acierto de mínimas garantías que solventaba el errante propósito escénico y espectacular.

Se hallaba el arte de la escena ante la presentación social de un recién nacido sin nombre, con necesidades de existir, con las dificultades de avanzar sin apoyos o reconocimientos y ante la apropiación impetuosa de novedades poéticas sujetas a creadores del arte que hallaron en esta circunstancia un lugar de acción, de vindicación y de ubicación de su misma propuesta artística, acaso hasta entonces, desconocida, aunque a veces, también, aun a pesar de validar y asumir el esfuerzo de conducir los proyectos incipientes, siguiera en esa ignorancia o reconocimiento.

La distinción de las personas hacía distintas a las propuestas espectaculares. La observación pertinente de cómo se activaba, validaba y convenía la participación fue pasando desde una intervención genérica desde los organismos del entorno social hasta adquirir hoy día un compromiso artístico y estético sin condiciones, enarbolando una máxima de hacer posible la realidad de este arte y consolidando la intención de ofrecer el canon o el paso definitivo de un arte en sí, frente a un arte solidario con la presencia de la diversidad humana en el acontecimiento escénico y espectacular.

En los más de cincuenta años de esta peripecia, se ha logrado admitir esa diferencia o cualidad intrínseca propia como dimensión estética y espectacular. Haciendo palpable la validación del referente emocional, físico o perceptivo-sensorial propio e individuado como el canon dialogable con el artificio artístico. Las normativas estéticas han debido corregir el propósito convenido, conformado y constante, para dar paso a una apertura orientadora en el rigor de lo presente como motor de lo posible, de lo imaginario, hacia un diálogo en la ficción, en la creación, en la factura de lo espectacular que surja de esa medida desproporcionada. Siendo este parámetro indefinido por lo humano diferente, el rigor de establecer una amplitud de intenciones en la conducta de lo estilizado, lo establecido y lo estructurado en la propuesta estética de la escena y el espectáculo. Lo presente y lo representativo ha confirmado el procedimiento propio 
de todos y cada uno de estos procesos espectaculares haciendo posible el cometido amplio y diverso de la creación espectacular contemporánea. Fundiendo parámetros de la Vanguardia, colisionando espectros de estéticas posmodernas, fulminando espacios de verosimilitud normativa, ampliando cánones de postulados artísticos en la diferencia humana y otorgando una amplio espacio de investigación, innovación, renovación y postulación de nuevas tendencias, aún sin nombre, pero nacidas con todas las sustancias nominales y adjetivadas posibles, con lo que se pueda ver la matización ampulosa y diversa en esta necesaria participación humana en la renovación artística como hasta ahora no se había dado. La irrupción de la diferencia humana ha hecho exponencial el grado del andamiaje de la estética espectacular, y ahora, la diferencia de la diferencia hace posible una atención infinita a un mundo ignorado, que acumula notorias sorpresas espectaculares sin definición y que contagian al mundo establecido y estilizado, sin saber cuál será ya el futuro sin definición que tendrán que seguir continuando en esta convivencia sin fin.

Atender a la diversidad humana, a la diferencia corpórea, al referente emocional sin censura, al ignoto campo de la percepción sensorial sin matices, hace posible que se lideren proyectos genuinos, novedosos, renovadores, capacitadores de nuevas atenciones del público y quizá, debamos ponerles datos compiladores que constituyan un fondo que vaya documentando el devenir de cada uno de estos proyectos, o de todos en su quehacer.

La escena inclusiva abre un lugar al debate de la dimensión humana en el arte del espectáculo sin referentes, pero con referencias en diálogo para atender a una historia presente en el arte de la escena. Los códigos y estrategias convenidas nos dan un detalle para establecer cauces en la documentación de la escena y la diversidad funcional, pero no llegan a ser eficaces en todo momento como garantes o referentes aglutinadores, niveladores o condicionantes de todo aquello que está siendo constituido, nuevo o reiterado, en su joven existencia. Acaso tengamos que atender a nuevos cauces de expresión estética, a nuevos engarces gramaticales de intención artística, a nuevos enlaces sugerentes en su metáfora para hacer posible esta significación presente, que hace referencia a un mundo humano, particular y social, pero sugerente en su condición de irreverencia creativa frente a su colapso de discurso escénico, sin nombre, sin pasado y con un presente que atisba un futuro incierto por cuanto no se logra cubrir todas las expectativas que plantea.

La Metaescena, sin fines de mayor infinitud, plantea un término de análisis artístico, estético y espectacular que se hace cómplice con otras atenciones de lo que se hace más allá de lo físico, de lo material y desde lo presente, y que tantas otras significaciones artísticas han nutrido o matizado en ciertas referencias 
en la historia del arte del espectáculo: "Metafísica del Teatro", "Metateatro", entre otras.

La irrupción de la realidad de la presencia de las personas con diversidad funcional, sin ser novedosa, se ha hecho novedad. Su actividad creativa y artística se enmarca ya de forma sólida en los escenarios de todo el mundo, aunque no de igual forma su validación artística convenida ni su realidad funcional profesional.

La presencia de la función humana distinta hace posible una amplitud de lo espectacular. Anota la falta de relatos sin estos cortes presentes en su mensurabilidad artística. Hace palpable la ausencia de referentes continuados, frente a la extraordinaria presencia en festivales, programas especializados o programaciones "exclusivas-inclusivas". Se vincula con notoriedad a espacios sociales de celebraciones y reconocimientos. Estandariza una exigente participación colectiva específica y no plural, por cuanto los grupos de acción artística inclusivos siguen siendo exiguos frente a los propios continuados en actividades específicas y conformativas para el grupo identitario. Consolida una extraordinaria vindicación política en tanto no logra ser un activo económico, difícil medio y fin para que alguna vez lo sea. Y finalmente, sigue siendo un parangón mencionado en planes educativos que nunca logran afianzarse ni rentabilizarse.

Todo ello hace que el norte de cada uno de los proyectos que consolidan esta fase de la Metaescena, la denominada actualmente, "Escena Inclusiva", sea al fin y al cabo un retazo más de mínimos, exigida, pero falta de exigencia. Por tanto, ausente o ahuyentada del territorio primordial de lo espectacular, afincada a un lugar recóndito y estigmatizado, separada sin ser propia, por impropia definición, y reconocida en su largo viaje sin fin a ser de una vez por todas madura en su quehacer artístico.

Sin embargo, la "Escena Inclusiva" ha logrado un marco propio, definido por el rol de lo humano en su diversidad, frente a cualquier garante artístico. Quizá por eso sea una denominación conveniente, pero no motivadora en su rasgo analítico. En tanto hallamos otro, acaso haya que convivir coneste, aunque conviene que exijamos rigor a quienes llevamos trayectoria en este vivencial modus viviendi artístico, por cuanto se nos dé fácil existir en tal salvedad. No obstante, debiéramos estar atentos a que no nos soliviante esta razón humana, sin razón estética en el término, único lugar donde el debate del arte tiene en gran parte su devenir.

Al trabajar con la presencia de la diversidad corporal, sensorial o intelectual nos encontramos con un campo de expresión artística y estética escindido, entre la realidad de estas circunstancias y las búsquedas de los propósitos de la ficción o el acontecimiento espectacular. El manifiesto uso de la diferencia en el 
conglomerado de la creación escénica pone en un balance artístico y humano el referente espectacular. Ofrece al componente escénico una versátil amplitud de referencias, y obliga al fin de la apuesta escénica a clarificar el código en que va a ser establecida la propuesta artística. Los cauces establecidos en los patrones tradicionales se tuercen hacia una voluntad performativa notoria, haciendo que el estilo y el juego creativo y artístico busquen un diálogo en la contemporaneidad escénica. El discurso escénico valora la condición humana y el fin artístico, ejecutando un lazo dialéctico sin fin, que hace posible un diálogo verosímil entre la realidad de los cuerpos y el debate de las intenciones artísticas. Establecer en ese diálogo la formidable traza de los espectáculos de escena inclusiva se convierte en el gran aporte novedoso, y también en la consolidación de estéticas que identifiquen la presencia de estas diferencias en la presencia humana como motor de la apuesta espectacular.

Se hace obvio e inexcusable encauzar esta noble apuesta, pero no se logra afianzar más que en el debate de la performatividad o la posmodernidad el referente fundamental que lo habilite ${ }^{2}$. El discurso de la realidad artística se ve redundante y solo ofrece un rigor de la intención documental, vivencial y declarativa, y a veces ilustrativa, sin norte funcional o artístico. La mujer que traza el conflicto de género tiene tanto sentido en una fábula como el motor de la realidad de la discapacidad en el conglomerado de un argumento. El discurso se halla consumado y colmado de coherencia, haciendo que ese debate y documento artístico logre su propia definición en la mera presencia de estos artistas. Sin embargo, la eficacia de sus aportaciones, si se desean separar de esa condición de naturaleza presente, se alejan de facturas de excelencia y eficacia. Tendremos que valorar si la mirada artística sobre los referentes humanos se logra distanciar como soporte documental hacia un registro artístico, alejado de que esa presencia no sea solo cauce a ser referente de sí misma, en distancia de cualquier intención que apuesta por lo artístico por encima de lo referencial humano.

Es evidente que el cine logra esta perfecta comunión y orientación. Sin embargo, en el arte escénico asistimos a una larga y nutrida fase de hallar hasta dónde la idiosincrasia del material humano solo otorga fundamento artístico como fundamento a partir del documento real, en toda su extensión. El cuerpo performántico de la Vanguardia o el arte de la performance usaba el referente no como identidad social, sino como escalada artística y estética, ahondando en el discurso político, ante la intención clásica, narrativa cerrada o atención

2 Remito a la magnífica tesis doctoral de Marisa Brugarolas como argumentario detallado y conveniente a este propósito, cito pág. 264, Universidad de Valencia, 2016. 
aristotélica de lo espectacular. Lo inconsecuente, la ilógica o el azar ante la expectación y el referente espectacular, saltaba en su forma y fondo frente a los espectáculos tradicionales. Pero siempre en un puro debate artístico y estético, con su calado político, pero nunca el concerniente propósito de que un cuerpo con las características que lo condicionan, fuera en sí el soporte notorio y suficiente del acontecimiento espectacular. Esa forma de cuerpo, instaurado en un canon social de rehabilitación, nutre el propósito espectacular comúnmente, nunca alejado de su condición, lo que hace que impacto y acontecimiento frente a mensaje y referente físico se sublimen. Abrir un marco de atención escindida entre lo que se hace y quién lo hace, y de ahí nutrir el análisis como forma conveniente, es lo que aún sigue estando sin ocurrir. El nivel de la presentación artística de un cuerpo social no ha logrado escindirse en toda su manifestación, y es la intención que casi siempre se sonsaca, en tanto no se aleja la manifestación identitaria de la presencia de las personas con discapacidad de su notoria afectación, peyorando el propósito de efecto espectacular en un fondo de intención social que no consigue labrar un relevante discurso artístico desde el que se le condicione su itinerancia, su voluntad de existir y su razón única y exigida en el debate del arte escénico.

Seguimos entre la rehabilitación artística, el documento poético social y el evento circunstancial del cuerpo en su hiperbólica presencia. Estos tres parámetros en los diálogos espectaculares del teatro, la danza y el circo, pues son los que nunca esconden sujeto y objeto, sino que descarnadamente ofrecen su pugna en el debate artístico y estético ${ }^{3}$.

Por lo tanto, la Escena Inclusiva ha incorporado profusamente toda la desmesura nominal antecitada: distinta capacidad, capacidades diversas, integración artística, etc.; mas no ha logrado atildar un espacio de quehacer artístico genuino en su denominación, aglutinándose en los tres contextos anteriores. Convivir es obligado, pero hallar su lugar de avance estético y artístico en su definición, deberá ser un propósito en un futuro por hacer, en tanto los proyectos que lo circunscriben, bajo ese legado, no abandonan el lugar social del que salieron, no adquieren un entorno del devenir artístico en estilo y estética y acaso lo peor, su vindicación política se deshace en el norte de lo profesional hallando en la circunstancia explícita de su prodigalidad en la distribución, la mínima tabla de salvamento en este presente insustancial en el arte de la escena y en la impronta notoria del arte del espectáculo. Se deberá atender por muy distintos lados este

3 Podemos atender una valoración al cuerpo y al sentido artístico, social y emocional en la tesis doctoral de Pilar Muñoz, Universidad Rey Juan Carlos, Madrid, 2017. 
territorio por nombrar, por cuanto la identidad es lo que hace patente aquello que era solo potencia, y eso, en el mundo del arte, lo sabemos vivir sobradamente ${ }^{4}$.

\section{La accesibilidad universal}

\subsection{Contexto y marco actual}

Desde hace dos décadas, se viene experimentando una afluencia de personas con discapacidad o con diversidad funcional a la cultura y los espectáculos. Los programas sociales se han ido abandonando para ocupar la nivelación en propuestas de programas culturales, que las medidas políticas de los países han ido incorporando en sus propósitos de gobierno y en sus fines políticos. A partir de aquí, la intención de la accesibilidad espectacular se ha ido incorporando como vehículo de la comunicación artística universal, con la intención de mejorar la participación de las personas y de sus distintas necesidades a la hora de atender como receptores del espectáculo desde la mayor autonomía posible (Flys 2018) ${ }^{5}$.

Las aportaciones y útiles tecnológicos han favorecido este suceso. Pero aún queda una labor constante que atender en la creación espectacular, así como en las medidas convenientes a la recepción, a través de la intervención en los espacios de exhibición y de las programaciones de espectáculos inclusivos. Se hace necesaria la accesibilidad espectacular para conseguir que la nivelación social se logre en el acceso a la cultura. Se sigue sin cubrir los espacios de exhibición de las necesidades técnicas necesarias además de no lograr una labor continuada en la programación inclusiva y accesible. Esto hace que el público con diversidad funcional sea inexistente regularmente en las programaciones artísticas de los espacios de exhibición, además de que el público general vea de forma extraordinaria la presencia de la diversidad tanto dentro de la escena como fuera en la platea.

La intención de festivales y espacios de exhibición extraordinarios sigue siendo la manera de atender en exclusivo a los espectáculos con personas con diversidad funcional. En el término de la accesibilidad de estos espectáculos, se suele recoger por la actividad programada por la producción del evento en sí, recayendo en profesionales que vienen ocupando la intención de la accesibilidad del espectáculo desde iniciativas de muy distinta índole.

4 Es apreciable el estudio de la danza dentro del currículo de los conservatorios superiores en la tesis doctoral de Carina Martín Castro, Universidad de Granada, 2017.

5 Puede ampliarse este análisis en la excelente tesis doctoral de Elena Sánchez-Vizcaino Flys, Universidad de Alcalá de Henares, Madrid, 2013. 
A nivel oficial, desde la universidad en concordancia con el Real Patronato sobre discapacidad desde hace más de dos décadas, lleva la labor de asesoría, educación y atención artística a la accesibilidad espectacular el CESyA, Centro Español de Subtitulado y Audiodescripción, organismo dependiente del Centro Tecnológico de la Universidad Carlos III de Madrid y representante del Real Patronato sobre Discapacidad de España. También, a través de la Fundación Vodafone España, la empresa APTENT, Teatro Accesible, con cerca de una década de actividad. Otras empresas y actividades privadas vienen desarrollando tal actividad 6 . Y por supuesto, en cada entidad u organismo vinculado a las personas con discapacidad sensorial, fundamentalmente, ONCE, CNSE, FIAPAS, entre otras, o bien el programa Plena Inclusión, en atención a las personas con discapacidad intelectual, en su área de accesibilidad. Todas ellas han tenido una actitud pionera en el propósito de esta atención, dado que se han hecho cargo de forma primordial a la atención de los usuarios y asociados que demandaban la falta de atención y posibilidad como público para participar de espectáculos escénicos.

Asimismo, espacios de intervención y gestión cultural, como Madrid Destino S.L., órgano gestor dependiente del Ayuntamiento de Madrid, ha trabajado durante los dos últimos años desde su Área de Accesibilidad la atención a las medidas de accesibilidad de eventos y espectáculos, favoreciendo sobre todo la iniciativa pionera de hacer accesible espectáculos escénicos de corte no dramática, como la danza o el circo, además de eventos culturales o de ocio como exposiciones plásticas o visuales, así como Cabalgata de Reyes o Belén de Navidad ${ }^{7}$.

Estas circunstancias hacen patente la atención contextualizada y prevista desde organizaciones y espacios de exhibición, así como la respuesta conveniente de parte de empresas, organizaciones y entidades a la hora de posibilitar la accesibilidad espectacular, de eventos o de actividades artísticas o culturales. La valoración de todas estas iniciativas enmarca la actualidad que convive con las

6 Se puede visitar la página web de CESyA donde aparece un portal referente a todas las empresas que actualmente en España trabajan la accesibilidad para la escena.

7 La colaboración prestada a los programas de "Navidad" o "Veranos de la Villa" con la entidad gestora Madrid Destino, representante en la gestión del Ayuntamiento de Madrid, a través del Área de Accesibilidad e Inclusión, y por gentileza profesional de Vanessa San José, ha posibilitado aumentar muchas acciones innovadoras en el propósito de la labor en Accesibilidad espectacular que vengo realizando, en proyectos de danza, performance, eventos artísticos, exposiciones plásticas y fotográficas, entre otras actividades. 
personas con diversidad funcional en su derecho al ocio o al acceso a la cultura, sin embargo, siguen siendo atenciones eventuales, y no permanentes.

\subsection{Medidas de accesibilidad utilizadas}

Las medidas de accesibilidad más usadas tienen que ver con la atención a las personas con discapacidad sensorial. De a poco, la atención a las personas con discapacidad intelectual va creciendo en esta mínima situación y participación dentro del acceso a los espectáculos públicos. Es evidente que otras personas se pueden beneficiar de las atenciones que vamos a explicitar, pero no son desde luego posibilidades atendidas, habida cuenta de lo exiguo dentro de la atención desde los sistemas de producción y gestión a la atención a la accesibilidad espectacular.

Los mecanismos usados en la accesibilidad son los siguientes:

- Paseo táctil. Se realiza para personas con discapacidad visual. Se atiende un tiempo antes de que se inicie el espectáculo. Se establece un paseo presencial en la puesta en escena plástica (escenografía, mobiliario, utilería, indumentaria, atrezzo), acompañado por el referente narrativo de un conductor, encargado de hacer posible la descripción del espacio, los recursos plásticos, la dimensión escénica, el referente de los intérpretes de forma presencial, así como la exposición arquitectónica del espacio escénico en que se hallan.

Suele tener una duración aproximada de 15 a 30 minutos, según la complejidad del espectáculo. Se suele realizar con la eficacia y rigor máximo, haciendo en la medida de lo posible que participe el equipo artístico del espectáculo, así como la necesaria atención del equipo de producción del espacio de exhibición.

Se consigue una referencia escénica y artística que posibilita la atención del espectador con discapacidad visual en la subsiguiente audiodescripción, favoreciendo el marco descriptivo, así como la concepción de la puesta en escena del espectáculo en su potencial imaginario.

- Paseo escénico ${ }^{8}$. Se realiza para personas con discapacidad cognitiva. Se atiende a una visita guiada por la escena para atender a la clarificación de la puesta en escena a nivel plástico, espacial y con interacción con los intérpretes.

8 El paseo escénico se practicó por primera vez en el estreno del montaje "Lucrecia y Judith", de Marco Antonio de la Parra bajo la dirección David Ojeda con su compañía Palmyra Teatro en el Festival ÍDEM 2016, asistiendo un grupo de personas con discapacidad intelectual pertenecientes a Plena inclusión Madrid, Federación. Desde entonces es recomendado por dicha organización como medida de accesibilidad para personas con discapacidad cognitiva. 
Es aproximada a la que pueda tener en cuenta la atención del paseo táctil, pero además, se hace hincapié en la aclaración y descripción de contenidos temáticos, fabulares o acontecimientos dramáticos o escénicos que tengan sentido ser significados y realzados, con vistas a posibilitar la mayor autonomía posible como receptores del espectáculo.

- Audiodescripción. Es el material dramatúrgico y narrativo que se realiza a través de una alocución, si es grabado, o en locución si es en directo. Esta labor garantiza, aunada al paseo táctil, que la acotación o desarrollo narrativo y didascálico del espectáculo sea eficaz a toda aquella situación o desarrollo de acciones que sean convenientes detallar o mencionar como mejora de la consecución del espectáculo. Se debe atender de la forma más objetiva posible, con vistas a no modificar el pulso dramático o escénico, y así no dar una interpretación errónea del desarrollo narrativo del espectáculo.

- Subtitulación. Es el material dramatúrgico y narrativo proyectado sobre una pantalla de subtítulos. En esta descripción se atiende fundamentalmente al material dramático y espectacular que conviene matizar, realzar o aclarar para personas con discapacidad sensorial auditiva. Se mantiene relevante durante todo el espectáculo, y ha de buscarse una idoneidad entre la distancia a la escena del soporte de proyección o pantalla y la ubicación del público con discapacidad auditiva. Esta labor se hace conveniente, aun cuando no siempre se puede llevar a buen término.

- Intérprete en lengua de signos. Se añade como una posibilidad más en simultaneidad o en sustitución con la pantalla de subtítulos, para la recepción de las personas con discapacidad auditiva. Es una decisión del director de escena o del responsable del equipo artístico, mediado con el equipo de producción del evento, pues se hace conveniente una ubicación específica y debe estar en proximidad con el público con discapacidad auditiva. Dependiendo del referente espectacular, a veces, se hace inconveniente y por parte de la dirección se decide optar por el otro sistema. Asimismo, se debe atender la ubicación, siendo más específica la necesidad de cercanía, frente a la pantalla de subtítulos. En cualquier caso, dentro de la atención a la accesibilidad, se dan ambas como opciones posibles, y sirven como mejora de la atención espectacular?.

9 El público con discapacidad sensorial auditiva mantiene una relevante presencia y elección por el subtitulado espectacular, mantenido en los estudios analíticos y metodológicos presentados por CESyA, pero existe una atención espectacular en la escena inclusiva y en la accesibilidad de proyectos como la Cía. El Grito que hacen presente la lengua de signos como referente espectacular, con lo que cierta población de personas sordas siga prefiriendo esta atención comunicacional. 
- Programas de mano accesibles. Existen distintos programas de mano que permiten la accesibilidad que describiremos brevemente, activando la nota que aclara las distintas posibilidades.

- Programa en alfabeto braille para personas ciegas.

- Programa en aumento de caligrafía y tipo de letra, también para personas ciegas.

- Programa descriptivo de la dramatis personae y el color del subtitulado para personas sordas.

- Programa de mano en lectura fácil y con pictogramas para personas con discapacidad intelectual.

\subsection{Otras atenciones de la accesibilidad}

En toda la atención antedescrita, existen otras posibilidades y recursos que se han propuesto y se intenta ver su favorecimiento como medida de accesibilidad.

En un caso, la persona de acompañamiento de las personas con discapacidad intelectual se ha buscado como medida de mejora a la autonomía y acceso a los espectáculos. Esto se lleva a cabo siempre que el espacio de exhibición encuentra conveniente esta medida, valorándose como opción en su engranaje de gestión y producción, habida cuenta que deba ofrecerse en el propósito de difusión del espectáculo en cuestión.

También, la posibilidad de hacer funciones extensivas y durativas en la representación, favoreciendo la asistencia de personas con el espectro autista. Esto consiste en favorecer su presencia, siempre y cuando la persona desee, posibilitando su abandono de la ubicación como público para favorecer su momento de posible aumento de tensión receptiva emocional o cognitiva. También el anunciar o bien anular referentes del discurso escénico o espectacular que puedan distorsionar su conveniente atención, como disparos, gritos, acciones violentas con gran impacto visual o sonoro, entre otras.

Asimismo, la posible mantención de una iluminación no estridente en la escena ni realizar cambios bruscos en la narrativa lumínica, así como la posibilidad de permanecer una luz sugerente y no notoria en la audiencia con el fin de no mantener en oscuridad el espacio de la representación.

El hecho de no tener una cabina de locución para poder enmarcar en directo la audiodescripción hace conveniente que la medida narrativa esté muy ajustada al marco de la representación y del espectáculo. Esto hace conveniente que la prueba o ensayo de tal directriz esté llevada a cabo de forma responsable, siendo conveniente que el técnico que lance este material sonoro sepa en todo momento 
el desarrollo del espectáculo. Con ello, se intenta no estorbar ni saturar la información acústica de la persona ciega, pues debe estar siempre en perfecta atención y armonía con los dos canales sonoros simultáneos que mantiene, el del espectáculo y el de la audiodescripción.

La mejora de la ubicación del público con discapacidad sensorial auditiva para el referente del intérprete de signos o bien de la pantalla de subtitulado se hace conveniente, que no esté muy alejado, sin ser elevado en una inconveniente situación espacial, con motivo de favorecer y no desvirtuar la visión del espectáculo.

Asimismo, la ubicación de las personas con discapacidad visual en una zona próxima a la escena o espectáculo mejora su percepción en todo momento, pues el tránsito de los intérpretes con el movimiento escénico, la intensidad en el desarrollo de la acción o bien los matices sonoros o emotivos de la voz, hacen posible una mejor habilitación de su recepción del espectáculo.

La ubicación de las personas con discapacidad cognitiva también se siente influida en su capacidad receptora, bien por motivo de lo antes descrito, en el caso de las personas con espectro autista, o bien con la necesidad de que el desarrollo del espectáculo se halle en cercanía para facilitar la atención y no su dispersión en otros referentes visuales o sonoros que puedan hacer barrera comunicacional hacia su atención plena.

Estas apuestas están bastante detalladas en las referencias bibliográficas que remito, pero conviene hacerlo significativo para mejor entendimiento del artículo.

\subsection{Innovaciones en la accesibilidad}

A continuación, se describen medidas de intención conveniente para llevar a cabo la accesibilidad en espectáculos no narrativos o dramáticos. Es decir, danza, circo, performance, eventos culturales o sociales, exposiciones y audiovisuales, entre otros. Es la faceta que he venido realizando en estos dos últimos años, como medidas de innovación y atención espectacular pionera con mi vínculo como profesional de las artes del espectáculo y la atención a las personas con diversidad funcional ${ }^{10}$.

10 Esta labor se ha desarrollado en el vínculo profesional con la empresa de gestión y producción Madrid Destino S. L. en convenio con el Ayuntamiento de Madrid, dentro de las programaciones de "Navidad" y "Veranos de la Villa" 2018 y 2019, fundamentalmente, como he mencionado en una anterior cita. 


\section{La acción sobre un cuerpo funcional no establecido y sobreestilizado}

Ante cómo escribir un relato escénico en la accesibilidad en el desarrollo de la "acción", nos conviene establecer cuál es el código de un cuerpo eficaz, en su desarrollo en acción. Este cometido, aun cuando se hace cotidiano en la realización de la audiodescripción y la subtitulación, y no requiere mejor detalle que el relato de la acción física, se debe establecer como propósito objetivo y no subjetivo. No tanto por la adecuación sintáctica en el discurso, sino por su elección semántica y proyectiva de un significado eficaz y ecuánime con el discurso escénico.

Cuando la "acción" se hace ficcional en un cuerpo real, compromete su significado. Es decir, no se recibe, percibe o manifiesta de igual manera la función corporal de todo intérprete, si aparece ya sentado en una silla de ruedas o no, si actúa sobre alguna manifestación corporal motórica evidente o si su movimiento se ve modificado por la circunstancia sensorial o intelectual, acaso motivos conmovedores y trasformadores de la acción escénica.

A este detalle, habrá que añadir que no es igual la acción narrativa según qué estética o estilo o referente espectacular. Esto conlleva que describir cualquier verbo en esta circunstancia tenga una atención necesaria para hace patente la acción y su devenir en estilo, estética o registro espectacular en lenguaje escénico y artístico.

Por tanto, se vuelve conveniente que el "resumen activo" sea acondicionado a los códigos, conceptos y conocimientos que las personas con discapacidad tienen según su circunstancia vital. Por ejemplo, "susurrar" para una persona sorda, es un signo de información aprendido mas no percibido; "enfocar" para una persona ciega se puede convenir de la misma forma que el ejemplo anterior. Ambos verbos tienen su valor y su necesidad extensiva en el propósito informativo, evidente en la acción, no fáciles de entender si no por la experiencia personal de cada persona con discapacidad sensorial, a lo que se le añade que es notorio que tendrá una apreciación significativa según el registro, la estética o la función referencial del signo espectacular.

Esto hace que la elección de la "acción", de la palabra escogida en su discurso gramatical, llegue a condicionar el referente enunciativo conveniente y eficaz en todo momento en relación a la audiodescripción y la subtitulación.

\section{El espacio como metonimia de la imagen real en la palma de la mano}

El recurso de hacer significativo el marco actancial del espacio para una persona con discapacidad visual puede resumirse en la traslación de la planta escénica, del marco referencial sinecdóquico, a la palma de su mano. 
Habrá que orientar el marco arquitectónico escénico, su dimensión física, así como la referencia espacial escénica en sus vectores primordiales: proscenio, escena y foro, en el detalle del profundo, esencialmente, así como los otros vectores, ancho y alto, según signifiquen en el marco plástico escénico.

Aunar detalles significantes como referentes del mobiliario, de la escenografía o de la marca plástica de elementos corpóreos se vuelven el recurso más pragmático.

El detalle lumínico como fuente espacial referencial también tendrá su valor, pero deberá ser designado en tanto punto focalizado y dimensionada como motor del desarrollo del movimiento escénico o de una acción narrativa concreta.

Todos estos componentes deben ser relatados en la significación espacial de la mano, así podrá ampliar a lo escénico su función deíctica conveniente.

\section{La sintetización de la dramaturgia de la acción en la dimensión espacial, audiodescripción}

Es conveniente no dilatar la información en el detalle narrativo de la audiodescripción. Habida cuenta la función del paseo táctil, o si bien no se ha llegado a realizar, su conveniente aporte informativo inicial o acumulativo en la Audiointroducción del espectáculo.

El espacio debe acotar suficientemente el movimiento escénico, espacio explicado convenientemente como cota escénica referencial en el detalle plástico que se vuelve marco narrativo de la acción o movimiento escénico.

\section{La traducción del mapa emocional en el subtitulado}

Cómo escoger la palabra en su acepción de significado requiere el mejor detalle para el universo emocional y tensional del texto en el subtítulo. El grado semántico que califica, cualifica, matiza o pormenoriza es el detalle suficiente en todo marco explicativo de la emoción, la sensación o información activa de una expresión sonora.

Añadida esta labor a la propia dimensión visual espectacular durante la representación, puede hacer partícipe al espectador con discapacidad sensorial auditiva de una recepción autónoma conveniente.

Decir "alto", "suave", "fuerte", "delicado" pueden ser palabras en uso analógico para distintos detalles y matices de la voz o el recurso expresivo sonoro del espectáculo. Sin embargo, decir estridente, fortuita, saturada, ahogada pueden ser matices no eficaces a la información posible para una persona sorda. La elección de una u otra vertiente debe ser conveniente, y hemos de advertir que la 
información denotativa del campo emocional o expresivo del sonido es fundamental en el marco referencial de todo signo espectacular.

También la descripción cromática del color del subtítulo se podría organizar a partir del análisis del temperamento y el carácter a través del color, según se utiliza en otras intenciones analíticas. Esto haría que el color verde pudiera corresponder al temperamento melancólico o racional, el color azul atendería al temperamento flemático o calmado, el color rojo al temperamento colérico-apasionado y el amarillo al sanguíneo o idealista. Esta posibilidad, descrita en el programa de mano, facilitará la característica del personaje al hacer patente su carácter y comportamiento.

\section{La división en escenas narrativas del espectáculo}

Atender a un espectáculo no dramático requiere que el encargado del discurso narrativo y dramatúrgico de la audiodescripción, fundamentalmente, y de la subtitulación puedan tener suficientes y notorios conocimientos de qué es hacer dramaturgia. Asimismo, se debe aunar la capacidad de tener experiencia sobre el campo referencial artístico y espectacular de las personas con discapacidad. Puede que sea conveniente ambos marcos competenciales para llegar a una eficaz elección dramatúrgica y narrativa del documento audiodescrito y subtitulado. Esta consideración dará detalle de la descripción espectacular en ambos casos, haciendo eco de una dimensión interna y externa del referente espectacular en su designio accesible.

La gramática de la narración escénica a través de la teoría de las trasferencias, tanto para la dimensión visual hacia las personas con discapacidad visual, como la dimensión sonora para las personas con discapacidad auditiva

La mirada al signo poético de la escena no debe hacer perder la objetividad del relato en la accesibilidad. En cualquier caso, se puede atender en el propósito significante cómo operar en la intención de la sinestesia, ese caudal posible de poesía y significación, sin llegar a pervertir el relato como premisa fundamental. Pero también hacer valer la función narrativa sobre la mirada a través del tacto o del sonido a través de la mirada, sin entrar en otro orden operativo sensorial y gramatical, puede favorecer la elección del discurso gramatical objetivo, y por qué no poético, teniendo en cuenta que cuando estamos ante espectáculos no narrativos ni dramáticos hacer eco de ese aspecto funcional espectacular se puede volver necesario como pulso expresivo, estético y artístico. 


\section{La locución performativa: dimensión narrativa de la voz para trasladar el universo tensional y estilizado del espectáculo, matices entre la danza y el circo}

El uso de la voz en directo abre una experiencia necesaria para el marco de la audiodescripción en estos espectáculos no dramáticos. Frente a la locución neutra y mesurada, debido a que el referente emocional y expresivo se halla en el intérprete, aquí, el locutor, se vuelve intérprete de la narración, creación, expectación, tensión, sensación, sugerencia y más detalles comunicacionales, en su aspecto y dimensión fáctica, que favorecen el realce manifiesto de la dramaturgia y narración del relato de la audiodescripción.

\section{La realización sensoperceptiva del paseo táctil}

La experiencia performántica y sensitiva de la persona con discapacidad visual ante la participación en el paseo táctil se vuelve condicionante y estimuladora al imaginario de la dimensión plástica y estética del espectáculo que va a presenciar. Por cuanto, el referente sensorial y perceptivo de su acción dentro del marco escénico realza detalles que la sola descripción locutiva no daría suficientemente.

Lamentablemente, esta circunstancia no se ofrece fácilmente, por la conveniente producción que conlleva, y por cuanto se hace necesaria la presencia de un narrador consciente y conveniente con el detalle escénico y espectacular en su dimensión plástica, espacial y escénica.

La vinculación física en el entorno, enfatizado también con el contacto táctil con los intérpretes hace que fisicalicen el soporte de la voz, activen la imaginación a no elucubrar sobre la presencia del personaje, bailarín o performer; y dialoguen desde su referencia concreta con una posibilidad inimaginable de no haber tenido posibilidad de hacer concreta esta gran realidad de lo escénico. Tocar al intérprete es ver al personaje, al portador de la información espectacular y artística fundamental.

Es un recurso muy significativo cuando se produce, y una evidente inconveniencia su falta, por cuanto no se consigue en espectáculos de esta índole poder resolver con toda la eficacia perseguida la recepción espectacular. No obstante, la audiointroducción y el relato dramatúrgico de la narrativa escénica, pueden ofrecer un gran aporte, desde luego, aumentado y matizado por el paseo táctil ${ }^{11}$.

11 Mi labor en la accesibilidad se ha visto acompañada en distintos momentos por organizaciones y entidades distintas que quiero mencionar: CESyA, de quien he aprendido todo lo que sé; Plena Inclusión, con quienes colaboro en el quehacer de la accesibilidad hacia las personas con discapacidad cognitiva; CEAPAT, con quienes he entrado en 


\section{La dimensión dramatúrgica y escénica del paseo escénico}

Desde que realicé por primera vez esta apuesta perceptiva he visto de forma manifiesta su eficacia. Resume y reúne de forma contundente los puntos cruciales y referentes del espectáculo. Dispone a entender sensoperceptivamente a la persona con discapacidad intelectual, el lugar referente de la escena, desde su dimensión plástica, espacial y ficcional.

También, la información temática, contextual y fabular que se puede prestar al hacer esta atención condiciona la recepción del espectáculo, les sobrepone en una condición distinta, empática y suficiente, aportando mayor interés al saber un poco más de lo que más tarde van a presenciar. No es un avance sinóptico, que desvirtuase el posible relato, sino que en un acontecimiento con diferente propósito dramatúrgico, como pueda ser la danza o el circo, aún más complejo el performance, permita hacer partícipe en la medida de lo posible de su quehacer como espectador. Es evidente que esta aportación a un espectáculo de propuesta dramática aumenta sin equívoco tal eficacia receptiva como espectador.

\section{Conclusión}

A lo largo del artículo se ha intentado valorar la necesidad de la accesibilidad en el terreno de la escena, además de la escena inclusiva. El concepto y categoría de Metaescena busca marcar la relación creativa, artística y espectacular entre la puesta en escena y la accesibilidad.

Se analiza la situación de exigente actualidad de cómo se podría atender a medidas narrativas y creativas para favorecer la atención a la accesibilidad. Se sigue notando la ausencia de personas con discapacidad entre el público asistente. Esto hace decaer las medidas programáticas y políticas que buscan que la

contacto recientemente para la elaboración de maquetas en 3D; ONCE, con quienes me han ofrecido el apoyo a la realización en el programa en braille en ciertas ocasiones; con Elena S.V. Flys, con quien he venido de la mano durante toda la trayectoria de Palmyra Teatro en mi atención a la accesibilidad; y por último, y no menos fundamental, con el convenio que mantengo con la Fundación SYGNE por quienes mantengo la autonomía tecnológica que me facilitan con la cesión del material tecnológico para llevar a cabo la audiodescripción y la subtitulación, y con quienes mantengo activamente el programa ÁGORA-AHORA, que busca asesorar, sensibilizar y proponer la accesibilidad en todo espectáculo y evento que genero y que nos propongan. Agradezco también la atención personal y profesional en muchos ratos compartidos a Javier Jiménez, Director de APTENT-Teatro Accesible. 
diversidad funcional esté en el referente social constante de atención y búsqueda de posibilidades en su nivelación humana.

La necesidad de atender encauzadamente a estas iniciativas haría posible una sociedad más justa con las propuestas de inclusión, participación y empoderamiento en el acceso al arte y la cultura como derecho de las personas con diversidad funcional, aunque sigue siendo un deseo no instaurado en gran medida.

\section{Bibliografía}

Brugarolas Alarcón, Luisa María. 2015. El cuerpo plural. Danza integrada en la inclusión. Una renovación de la mirada; Tesis Doctoral, Universidad de Valencia, Facultad de Bellas Artes, Departamento de Escultura-Programa de Doctorado en Arte: Artes Visuales e Intermedia.

Martín Castro, Marina. 2017. Análisis de la atención a la diversidad en relación al currículum y las actitudes de los profesionales en los centro de enseñanza de danza; Tesis Doctoral, Universidad de Granada, Facultad de Ciencias de la Educación, Departamento de Didáctica de la Expresión Musical, Plástica y Corporal-Programa de Doctorado en Ciencias de la Educación.

Muñoz Morales, María del Pilar. 2017. Bases fisiológicas y psicológicas de las personas con Síndrome de Down para la danza clásica; Tesis Doctoral, Universidad Rey Juan Carlos, Instituto Universitario de la Danza "Alicia Alonso", Departamento de Ciencias de la Educación, Lenguaje, Cultura y Artes, Ciencias Histórica-Jurídicas y Humanísticas y Lenguas Modernas, Madrid.

Ojeda Abolafia, David. 2018. La inclusión artística frente a la accesibilidad espectacular; El teatro como herramienta de cambio; Madrid: Editorial Fundación Cannis Majoris, Colección Pensamientos Majoris.

Sánchez-Vizcaíno Flys, Elena. 2013. Comunicación y discapacidad sensorial: elaboración y análisis de una propuesta teatral accesible a todos; Tesis Doctoral, Universidad de Alcalá, Departamento de Filología, Comunicación y Documentación, Alcalá de Henares. 



\section{Marta Cantero Díaz \\ Asociación Paladio Arte, Segovia \\ Entidad declarada de utilidad pública. Asociación Paladio Arte}

Paladio Arte cumplió en el 2016 su 20 aniversario, siendo una de las compañías con más prestigio tanto a nivel nacional como internacional. La realización de 17 producciones, colaboraciones con María Pagés - Premio Nacional de la Artes,- o el haber actuado en el Centro Dramático Nacional, avalan nuestro recorrido.

Es una asociación sin ánimo de lucro que trabaja por la integración social y laboral de personas en exclusión social, principalmente con personas con discapacidad física, psíquica y sensorial a través de un medio tan eficaz como el teatro. Nos relacionamos con el arte contemporáneo como productora de obras y eventos culturales, como innovadora en el trabajo artístico realizado por personas con capacidades diferentes concebido no como una aportación de la sociedad al individuo sino como una aportación del individuo (como creador artístico) a la sociedad. Arte Contemporáneo concebido como una cultura importante para sí misma, para los individuos que la desarrollan, para las formaciones culturales locales en que se inserta, para los intercambios complejos entre culturas vecinas y como una fuerza capaz de generar tendencias en el marco de la alta cultura internacional.

Nuestros principales proyectos para conseguir nuestros objetivos son

- Centro especial de empleo Paladio Arte funcionando desde abril de 2007; la gestión depende también de una persona con discapacidad. Este centro se dedica a la creación y representación de espectáculos teatrales, de pequeño, medio y gran formato, haciéndolo único en todo el territorio nacional. El proyecto que dio pie a su creación fue premiado en la XII Convocatoria a Proyectos Emprendedores de la Obra Social de Caja Segovia.

- Compañía de Teatro Paladio, creada en 1996, trabaja de forma profesional por todo el territorio nacional, Francia y Portugal.

- Festival internacional Paladio Arte cuyo objetivo es llevar el mundo de las artes escénicas y las capacidades diferentes a toda la sociedad, contribuyendo así a su mayor conocimiento, sensibilización, aceptación e integración como ciudadanos y seguir demostrando que el arte integrado puede ser y es sinónimo de Calidad Artística. 18.000 personas han asistido. Llegan a Paladio anualmente 
decenas de solicitudes de todo el mundo para participar en este Festival. Algunas de ellas como Takku Liggey de Senegal, han visitado nuestra ciudad.

- Escuela de Teatro Paladio donde diariamente se imparten clases de voz, expresión corporal, improvisación, trabajo en grupo, lectura, memorización... trabajando al mismo tiempo una serie de capacidades de una forma lúdica y divertida: el teatro.

Nuestros proyectos más recientes son:

- Sala Teatro Paladio

- Los sábados al teatro

- Taller de teatro impartido por personas con diversidad. El Taller de Teatro, es un espacio de creación y acercamiento para todo aquel niño que desea volcar su mundo interior y convertirlo en expresión artística, al ser parte del profesorado personas con capacidades diferentes estamos contribuyendo al mejor conocimiento y al acercamiento de este colectivo a la sociedad, los niños de hoy son el futuro de mañana. Son varios los colegios y otros colectivos los que han disfrutado de esta actividad ofrecida por Paladio.

- Taller para formadores en teatro integrador. El objetivo fundamental de este taller es el de formar en todas aquellas particularidades que conlleva el trabajo con personas con capacidades diferentes en las artes escénicas, formación avalada por Paladio Arte con la metodología de Teatro Brut. Este taller está dirigido a profesionales que se ocupan de las áreas de creatividad, enseñanza de artes escénicas, dirección de escena, dramaturgia, análisis estético o desarrollo artístico, profesionales que trabajan con personas con diversidad funcional en cualquiera de sus facetas, trabajadores sociales, psicólogos, animadores socio-culturales... Proyecto realizado para la Federación Nacional de Arte y Discapacidad y Aisge.

- Campañas escolares. Las campañas de Teatro Escolar se configuran como un verdadero programa educativo que tiene como objetivo acercar a los niños a vivir la experiencia del teatro, desde un concepto pedagógico que involucre activamente no solo a los niños, sino a todos los que participan en su educación: sus padres, profesores y responsables públicos, a la vez que contribuya a formar ciudadanos con valores sociales como la igualdad, la tolerancia o la solidaridad. En colaboración con Compañía de Títeres La Tartana, se ha realizado una campaña escolar con colegios segovianos de la capital. 4.100 niños han participado en nuestras campañas escolares.

Otras actividades recientes son:

- Participación en las XI Jornadas TEVEO 
- Intervención en el Seminario en innovación social organizado en el marco de la asamblea general de la Red Europea de Centros Culturales ENCC

- Grabación a Paladio para el programa "para todos la 2", TVE

- Colaboración con la Universidad de Valladolid "Master de Comunicación con fines sociales"

- Producción de "pequeñas alegrías", exposición de fotografías y de documental del mismo nombre estrenado en MUCES

- Proyecciones del documental "pequeñas alegrías" Documental dirigido por Juan Carlos Gargiulo y producido por Paladio Arte

- "Taller de visión fotográfica" impartido por Juan Carlos Gargiulo

- Participación en la mesa redonda, "La alegría de la diversidad", dentro de la programación del XXXV Congreso Mundial ITI-UNESCO

- Exposición de la colección de fotografías "pequeñas alegrías". Festival internacional de Teatro de Elche FITEX, Centro Cultural L'Escorxador, Elche

- Participación en el Día de las Escritoras, 16 de octubre 2017

- Presentación del documental "Los dioses Olvidados" en MUCES Documental dirigido por Juan Carlos Gargiulo y producido por Paladio Arte

- Curso de Vestuario teatral. De la mano de Gema Roldan "Lolamurocostura"

- Durante 2015, 2016 y 2017 uno de los premios concedidos a proyectos sociales por Bankia y Fundación Caja Segovia

- DESEOS. Proyecto premiado en la convocatoria RETO 2019 del centro Dramático Nacional

Paladio Arte ha llevado el nombre de Segovia por los mejores escenarios de este país, desde el Centro Dramático Nacional hasta el Teatro Calderón, siendo algunos de sus espectáculos recomendados por la Red Nacional de Teatros. Muchos de los espectáculos de esta compañía han sido representados en Francia y Portugal, siendo nuestro trabajo y Segovia, conocido y reconocido internacionalmente.

Montajes de Paladio Arte:

1997. El Café de babel

1999. Alicia, mil pedazos de un espejo

2001. Clon

2004. Érase una vez ¿Un cuento?

2004. Don perlimplan y una clase magistral

2006. El Misterio del Barón Lamberto

2008. Voluntarina

2010: Ciranus circus

2012. Ulisea 
2015. NADIE (obra estrenada en el centro Dramático Nacional, Recomendada por la Red Nacional de Teatros)

2015. El Alquimista (con texto de David Herrero, -Puro Espíritu-. Una producción de Paladio Arte para Diputación de Segovia)

2015. No dejes que termine el día (dirección de María Pagés, Premio Nacional de las Artes, Producción Ayuntamiento de Segovia)

2016. BABILONIA

2017. Despierta, un juguete casi cómico

2019. DESEOS (obra dirigida por Antonio Álamo y María Parrato. Estreno en el Centro Dramático Nacional el 22 y 23 de junio de 2019). 


\section{David Ojeda \\ Real Escuela Superior de Arte Dramático Madrid \\ Palmyra Teatro}

\section{Sobre la compañía}

Palmyra Teatro apuesta por la creación escénica contemporánea incorporando intérpretes con cualidades diversas. El cuerpo, la voz y las emociones se conjugan en distintas posibilidades humanas para dar como resultado un espectáculo que pretende ser una representación de la sociedad diversa en la que vivimos. El arte escénico y las distintas capacidades son nuestra garantía de existencia artística. Atender a la diversidad humana es una obligación de las sociedades civilizadas. Mover barreras físicas y mentales es nuestro objetivo principal.

La intención es abrir también como compañía un foro de docencia en formación de profesionales, en integración artística, en talleres de investigación para incluir la diversidad funcional y la capacidad diversa como categoría estética o material escénico o participación activa como artista, la comunicación a través de conferencias o clases magistrales, así como participar en proyectos de colaboración con otras compañías que estén en el propósito de la integración; así como satisfacer a nivel de investigación cuanta documentación escrita, artículos, ensayos y/o publicaciones que se puedan llegar a dar a lo largo de su andadura artística y creativa.

Como punto primordial de la compañía, se halla la de plantear el propósito de la accesibilidad para público diverso en cada representación, haciendo eco en la difusión de estar siempre en esta necesidad, en esta realidad. Para que las funciones no sean específicas para el púbico con diversidad funcional sino que se permita su acceso para disfrute como acto de cultura, de ocio personal, posibilitando el hecho de no estar en una específica representación pactada sino en una apuesta de apertura de la creación escénica para todos los públicos en todo momento. Con ello, se ha contado para la propuesta de accesibilidad con la inestimable colaboración y asesoría del Real Patronato sobre discapacidad a través del CESyA y la UC3M para realizar el trabajo de subtitulado en distintos momentos con diferentes programas, en la actualidad, ACCEVENT o a través de aparatos de recepción. Esta asesoría y formación de la compañía hace que sea uno de los proyectos pioneros en la actualidad a nivel nacional en este propósito: gestar el espectáculo accesible desde la propuesta de puesta en escena, no como intención añadida, que es lo que normalmente se hace cuando se realiza la accesibilidad del espectáculo. 
Por último, la intención educativa del teatro lo pretendemos extender al público de ámbito universitario, así como el de educación primaria y secundaria, con motivo de atender a la sensibilización de un público potencial futuro que esté en consonancia con las intenciones que propone la compañía: una visión cultural y social del arte de la escena en la que todos los públicos puedan disfrutar de la función, sin menoscabar la disfunción preliminar que pudiera tener una persona por su discapacidad, convirtiendo cada representación en una mejora para la sociedad por atender la diversidad que la configura y la visión personal que la constituye en todo momento, unir ocio y cultura en una dimensión humana universal.

\section{Proyecto ÁGORA-AHORA}

El Proyecto ÁGORA-AHORA pretende acercar la atención a la diversidad desde diferentes ámbitos: la creación escénica diversa y la accesibilidad universal. Busca un espacio que logre una sensibilización entre distintos contextos sociales, desde lo educativo hasta el marco de las organizaciones de las personas con discapacidad, pero que en definitiva se vincula a una mirada niveladora y socializadora de las personas en sociedad.

Desde el principio de sus planteamientos, Cía. Palmyra Teatro busca la intención necesaria no ya de incorporar a las personas con diversidad funcional a sus espectáculos como una vía de inclusión profesional sino también como una mirada de avance en la creación contemporánea que ha supuesto el trabajo de la diversidad en el marco de propuesta espectacular de finales del siglo pasado y la actualidad del que nos encontramos. Pero este motivo no nos parecía suficiente, pues hallamos que aun cuando el arte del espectáculo se nutre en muy distintos parámetros para su alimento ficcional de todo el motivo genuino de las personas con discapacidad, en muy distintos paradigmas estéticos y artísticos, se sigue manteniendo en una circunstancia insólita al no favorecer la posibilidad de acceso como audiencia a este contexto social que tanta iniciativa creativa ha dado durante dos milenios. Por este motivo, Cía. Palmyra Teatro quiere abordar en sus intenciones este hecho inaudito y con su labor favorecer el que los espacios de representación amplíen sus propósitos de audiencia posibilitando con las medidas de accesibilidad espectacular que hoy día se desarrollan.

AGORA-AHORA busca la propuesta inclusiva en la escena y la intención de accesibilidad que favorezca el acercamiento de un público diverso a cada uno de sus espectáculos y representaciones. Como en el origen de la cultura occidental, en el mundo griego, el Ágora posibilitaba la manifestación social y participativa del ciudadano; quizá lo tengamos como algo idílico, mas nunca debiera ser ni una utopía ni una quimera, pues existe una gran porción de la sociedad, que 
a causa de su circunstancia, se halla estigmatizada para el acceso público a la cultura, la cultura escénica y espectacular, debemos tenerlo en cuenta como una situación que debe ser modificada por muchos y distintos motivos de derechos de la persona, pues seguimos incurriendo en una situación cargada de ignominia y que es obviada en muchos y distintos parámetros de la realidad del arte y la propuesta cultural vinculada a lo escénico y espectacular al día de hoy.

Los objetivos son:

- Promover un arte inclusivo en la creación escénica

- Atender a la mirada de la accesibilidad universal para un público diverso

- Favorecer un cambio de perspectivas en la manifestación y participación en el arte escénico a nivel social y humano

- Sensibilizar a la sociedad a través de un espacio común de relaciones como audiencia a partir de la asistencia a un espectáculo escénico.

Se pretende llevar a cabo una serie de representaciones con coloquio final con los asistentes en un marco de rango social de entre los 15 a 18 años. Entendemos que esa zona donde el individuo está desarrollando su perfil humano, en plena intensión de su temperamento y comportamiento, debe recibir información conveniente que le haga tener una mirada distinta y con espíritu valorizado a la hora de ver cuáles son las distintas obligaciones y necesidades que las personas tienen para vivir en sociedad.

ÁGORA-AHORA se quiere enmarcar en este fin y para ello plantear experiencias de intercambio a través de los proyectos de Cía. Palmyra Teatro. Vincularlo al público estudiantil de los últimos años de la ESO y de Bachillerato, intencionando la unión de centros educativos donde se dé la inclusión, así como los centros que impartan bachillerato artístico, siendo estos los posibles candidatos iniciales; aun cuando puede y deba extenderse a cualquier centro en ese ámbito de edad educativa, por cuanto sirva a toda la sociedad, aunque haya un lugar primordial al que pueda llegar a atenderse.

También se ampliará el propósito a todas y cuantas instituciones de personas con discapacidad se hallen próximas o dentro de los municipios o entornos cercanos, para así producir un espacio público y diverso en la audiencia que motive un día de encuentro humano en el marco de un ámbito cultural y artístico.

En otro apartado, el proyecto está siendo escaparate para innovar en medidas de accesibilidad y proyectar las expectativas a espectáculos no teatrales, como danza, circo, performance, exposiciones plásticas y visuales, eventos culturales y artísticos, facilitando la asistencia de personas con discapacidad a espectáculos que favorezcan la recepción y que hasta ahora no habían sido realizados, por ahora, en colaboración con la entidad de gestión Madrid Destino S.L. en vínculo 
con el Área de Accesibilidad e Inclusión en programaciones culturales de distinta índole.

\section{Actividad profesional de la Compañía:}

- Festival Almada, Portugal, 2015.

- Festival Escena Mobile, Sevilla, Compañía Danza Mobile, Teatro Alameda, 2016.

- Festival ÍDEM, Casa Encendida, 2016.

- Festival ARTRASFORMA, Mercats de las Flors, Barcelona, 2017.

- Festival de Almagro, Teatro Municipal, 2018.

- Teatro Auditorio Padre Soler, Universidad Carlos III, Leganes, Madrid, 2012, 2018, 2019.

- Teatro Cuarta Pared, Programación regular, temporada 2013.

- Teatro Municipal de Ávila, 2014.

- Diputación de Jaén, Palacio de Villardonpardo, 2019.

- Teatro Auditorio Municipal de Ourense, 2019. 


\section{Esmeralda Valderrama Vega \\ Danza Mobile, Sevilla \\ ¿Qué es Danza Mobile?}

Diversidad. Arte. Participación Social, inserción laboral. Estas son algunas de las piezas fundamentales de un puzle que Danza Mobile se propuso armar en 1995, a través de un proyecto con el que crear un espacio en el que se uniesen el mundo de las artes y el de la diversidad. Un trabajo común entre profesionales de ambos sectores con el que contribuir al desarrollo personal y social mediante el proceso creativo de las personas con diversidad funcional.

Danza Mobile lleva 23 años trabajando a través de un Centro de Creación de artes escénicas y plásticas, una Escuela de Danza y una Compañía de Danza Contemporánea. Así mismo, organiza en Sevilla desde hace doce años el Festival Internacional Escena Mobile de Arte y Diversidad.

Filosofía y aspectos fundamentales de Danza Mobile: Nuestra premisa es que el arte dignifica a la persona y saca lo mejor de nosotros mismos, potenciando quienes somos.

$\mathrm{El}$ arte no conoce idiomas por eso se establece un lugar de encuentro y de interacción con el espacio y con los otros.

Trabajamos desde el entendimiento de la diversidad, todos somos diferentes, y el respeto a esto nos enriquece.

Para nosotros es imprescindible contar con profesionales de las artes, no se puede enseñar nada si no se siente pasión por lo que se hace. Además esta profesionalidad de los docentes los dota de recursos para poder desarrollar las individualidades del alumnado.

Desde Danza Mobile se trabaja en dos vertientes, por un lado, potenciando, en primer lugar, el desarrollo personal y, a la vez, el artístico (este no existiría sin el primero).

Pensamos que el desarrollo de la creatividad es una base fundamental para crecer como personas. El ser humano tiene necesidad de dejar su impronta en todo lo que hace. Nosotros favorecemos que cada persona encuentre su identidad y pensamos que el arte es el mejor vehículo para ello. 

II. Inclusión y expresión personal 

Beth E. Jörgensen

University of Rochester

\title{
La escritura autobiográfica de la discapacidad: la teoría articulada en primera persona
}

\begin{abstract}
This chapter offers an analysis of two examples of disability life writing with a view toward demonstrating what can be learned about the social meanings and the embodied experience of disability in Mexico from first-person accounts. Carta a mi padre: Testimonio de una persona transexual con discapacidad by Irina Echeverría reveals the complex intersection at play within the family unit and the larger society of the stigmatized identities of disability and gender dysphoria. Identified as male at birth, for much of her life both prior and subsequent to her transition, Echeverría was subjected to intense discrimination and even punishment for her nonconforming expression of self as both disabled and transsexual. Recent poetry by Ekiwah Adler Beléndez engages in a creative interpretation of his experience of living with cerebral palsy. Two poems from his forthcoming collection "Amor sobre ruedas" critique the medical model of rehabilitation and the tendency to acquiesce to the protection of a strong family circle, while also celebrating those same family ties, sexual intimacy, fatherhood and his embrace of his anomalous body with its unique potential for movement.
\end{abstract}

Keywords: disability life writing, México, Irina Echeverría, Ekiwah Adler Beléndez, escritura autobiográfica de la discapacidad

En 2010, cuando empecé a explorar el campo de los estudios de la discapacidad, había pocas publicaciones que trataran la literatura hispanoamericana en contraste con la amplia bibliografía sobre la discapacidad en la ficción y la autobiografía norteamericanas y europeas. Por cierto, encontré el libro de Susan Antebi, Carnal Inscriptions: Spanish American Narratives of Corporeal Difference and Disability, y el artículo "Cryptic Triptych" de Ryan Prout, que me sirvieron de ejemplo e inspiración. En la última década, ha aparecido un creciente número de libros y artículos sobre la cultura española e hispanoamericana a través de los estudios de la discapacidad, la mayoría de ellos escrita por académicos que trabajan en el Norte global. Hasta el día de hoy, es válido decir que en la academia hispanoamericana los estudios de la discapacidad tienen más presencia en las ciencias sociales y médicas que en las humanidades. ${ }^{1}$ En el Sur global en

1 Véanse por ejemplo: Disability studies and Spanish Culture y Cognitive Disability Aesthetics de Benjamin Fraser, Accessible Citizenships de Julie Avril Minich, The National Body in Mexican Literature de Rebecca Janzen, Libre Acceso: Latin American Literature 
general, los que trabajan este campo tienen una orientación hacia los temas del desarrollo económico, la rehabilitación, la pedagogía, los derechos humanos y la inclusión. Respecto de teorías y metodologías, un aporte fundamental hecho por algunos estudiosos de las ciencias sociales en el Sur global es su crítica de la hegemonía de las teorías producidas en el Norte global o el mundo minoritario. Como explica la australiana Helen Meekosha en "Decolonising Disability: Thinking and Acting Globally" el "one-way transfer of ideas and knowledge" desde el Norte hacia el Sur ha sido un obstáculo para la comprensión de la discapacidad en el mundo mayoritario y muestra una lamentable ignorancia del valor de otros conocimientos.

Disability studies was constructed as a field of knowledge without reference to the theorists, or the social experience, of the global South. There has been a one-way transfer of ideas and knowledge from the North to the South in this field. This paper argues that contemporary disability studies constitute a form of scholarly colonialism and needs to be re-thought taking full account of the 400 million disabled people living in the global South. (668)

Shaun Grech y Dan Goodley también promueven la decolonización de los estudios de la discapacidad en el mundo mayoritario y, en su artículo "Doing Disability Research in the Majority World", argumentan que es esencial desarrollar métodos participativos de investigación y diseñar proyectos con una fuerte dimensión colaborativa en los que actúan las mismas personas discapacitadas como coinvestigadores y no "sujetos" pasivos del estudio (45). Igualmente reconocen el valor de formas híbridas del saber que combinan conocimientos indígenas con los producidos en el mundo minoritario. Grech y Goodley utilizan el neologismo "glocal" para denominar este proceso (45). En sus investigaciones en Guatemala, Grech emplea metodologías participativas para estudiar el impacto de los programas de desarrollo en las personas discapacitadas pobres y sus familias. Su libro Disability and Poverty in the Global South: Renegotiating Development in Guatemala documenta trabajos realizados en regiones rurales de Guatemala que constituyen una labor académica y política colaborativa, dedicada al cambio social y a la justicia económica. Meekosha, Grech y Goodley, a pesar de enfocarse en temas tratados en las ciencias sociales y no en las artes y las letras, aportan conceptos y modos de pensar la discapacidad en el Sur global

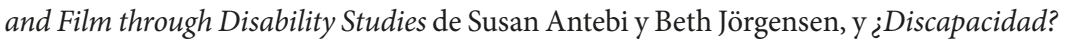
Literatura, teatro y cine hispánicos vistos desde los 'disability studies' de Julio Checa y Susanne Hartwig. 
que también pueden orientar el trabajo de los humanistas sobre la literatura, el cine y otros productos culturales.

Un libro reciente de Beatriz Miranda Galarza, concebido según los principios de la acción participativa, nos acerca a las cuestiones centrales para los estudios literarios de la discapacidad porque consta de relatos narrativos de la experiencia humana. Nuestra historia no es mentira: Vivir con "lepra" en Ecuador es una compilación de testimonios de los últimos residentes o, mejor dicho los últimos encerrados que padecen la enfermedad Hansen, en el Hospital Gonzalo González en Quito. En la introducción a la antología, Miranda Galarza describe el proceso colaborativo y de mínima edición que emprendió con los sujetos testimoniales para crear narrativas personales que documentaran y analizaran la enfermedad Hansen "desde su construcción social y política, más allá de los umbrales de la medicina" (13). Cita, además, a uno de sus colaboradores, don Bolívar, quien advierte que "Si publica un libro sobre nuestras vidas, ese libro va a ser prestado. No le pertenece, porque las historias son nuestras" (16). Desde la prehistoria, el ser humano narra y escucha relatos que explican los fenómenos naturales, narran el pasado y el presente de su sociedad e informan sobre experiencias propias y ajenas. Al grabar y transcribir los testimonios publicados en Nuestra historia no es mentira, Miranda Galarza y su equipo han recuperado una perspectiva ignorada por las ciencias médicas y la sociedad en general.

Sin embargo, las metodologías que emplean Meekosha, Grech, Goodley y Miranda Galarza no se prestan fácilmente a los estudios literarios y sus procesos frecuentemente solitarios de lectura y análisis de textos escritos por las élites culturales. En vista de la predominancia de los estudios literarios de la discapacidad generados en el Norte global, los investigadores que trabajan este tema en la literatura latinoamericana desde la academia del Norte y que desean contribuir con la teorización de los significados de la discapacidad enfrentan un dilema: cómo concebir y llevar a cabo sus proyectos sin incurrir inconscientemente en "the one-way transfer of ideas and knowledge" y sin limitarse a representaciones de la discapacidad creadas por escritores y escritoras que no se identifican como discapacitados. Una aproximación a este reto es enfocarse en "disability life writing", es decir, la escritura autobiográfica de la discapacidad que se produce desde dentro de la sociedad hispanoamericana. Este ensayo forma parte de un proyecto que trata diversas formas de escritura autobiográfica de la discapacidad producidas en México en los siglos XX y XXI. La investigación parte de la premisa de que estos textos, que incluyen la narrativa, la poesía y el ensayo personal, ofrecen percepciones y perspectivas críticas sobre los significados sociales de la discapacidad tanto como sobre su impacto material en la vida y la subjetividad del individuo. Es más, desde la antigüedad, la literatura ha prefigurado en forma 
narrativa muchos conceptos teóricos que son desarrollados luego por académicos y activistas. Por consiguiente, leer la escritura autobiográfica como una fuente de conocimientos puede contribuir con la teorización de la discapacidad y tiene el valor de hacerlo desde dentro de diversas experiencias situadas en una determinada cultura.

En el contexto de la sociedad estadounidense, los análisis hechos por G. Thomas Couser y Susannah Mintz en sus libros Signifying Bodies: Disability in Contemporary Life Writing y Unruly Bodies: Life Writing by Women with Disabilities respectivamente, ilustran este potencial. Couser investiga la relación entre discapacidad o enfermedad y narrativa personal en el contexto del prestigio otorgado a la salud y el control personal sobre el cuerpo en los Estados Unidos. Al recordar también la predominancia del modelo social en 1997 cuando publicó Signifying Bodies, es notorio que Couser encuentre en las narrativas autobiográficas un énfasis innovador en la naturaleza somática de la subjetividad humana y la contingencia de la identidad y el plan de vida del individuo. Mintz asevera que la autobiografía personal femenina plantea un desafío a ciertas ideas fundacionales del feminismo y ofrece una política y una poética de la identidad de la mujer discapacitada. La autobiografía de la discapacidad en Hispanoamérica ofrece textos igualmente valiosos para los estudios de la discapacidad.

En este ensayo, trato dos textos mexicanos: una carta autobiográfica escrita por Irina Layevska Echeverría Gaitán, una persona transexual con discapacidad, y un nuevo poemario en preparación de Ekiwah Adler Beléndez. En estas obras, temas relevantes como el dolor y el placer de habitar un cuerpo anómalo, el cuestionamiento de la prioridad de la rehabilitación bajo el modelo médico, el derecho de tener una vida sexual, la experiencia de rechazo y exclusión y la interseccionalidad de factores estigmatizados son sujetos a una mirada crítica con proyección hacia las relaciones sociales y no solo como asuntos exclusivamente privados. Todos ellos son manifestaciones de la teoría de la discapacidad articulada en primera persona desde dentro de la experiencia de vivir con una discapacidad.

Irina Layevska Echeverría Gaitán es una militante política, activista por los derechos humanos y la igualdad de los géneros sexuales, antiguo miembro del grupo asesor externo de CONAPRED y protagonista del galardonado documental Morir de pie de 2011. Carta a mi padre: Testimonio de una persona transexual con discapacidad salió en 2008 con CONAPRED bajo el nombre de Irina Echeverría. El texto fue producido en colaboración con Lourdes Díaz, quien entrevistó a Echeverría y adaptó las entrevistas a una narrativa epistolar testimonial. Cuenta la vida de Echeverría, quien tiene una discapacidad física causada por la polineuropatía degenerativa crónica. Además, antes de enterarse de lo que 
significa ser transexual, vive por mucho tiempo con la intuición de no ser hombre, sino mujer a pesar de haber nacido físicamente varón. A la edad de 36 o 37 años comienza el proceso de transición corpórea e identitaria para ser mujer, un proceso que la aleja definitivamente de su familia y de muchos antiguos amigos y compañeros de trabajo, y la deja vulnerable a la hostilidad de sus vecinos. Carta a mi padre se enfoca principalmente en su trayectoria personal y sus relaciones familiares. No trata su militancia en Nicaragua ni con el EZLN, ni tampoco trata en detalle su activismo en solidaridad con Cuba o su activismo en México con el PRD. El documental destaca estos episodios de su vida y podría estudiarse como un texto complementario a la autobiografía epistolar.

Carta a mi padre capta la voz de una persona que experimenta la discriminación y la exclusión debido a una intersección casi única de múltiples factores estigmatizados en la sociedad mexicana: tener una discapacidad física, ser comunista y ser una persona transexual. El lenguaje y la estructura narrativa de la carta no son tan complejos como lo que se puede encontrar en una autobiografía escrita por un autor o una autora profesional, pero la obra tiene el valor de hacer legible para un público amplio una experiencia de la otredad construida, así como el terrible costo del exilio interno de los llamados diferentes. Al escribir la carta, Echeverría se enfrenta al reto de dar visibilidad y legitimidad a un sector marginado y muchas veces violentamente agredido a través del mundo. $\mathrm{Al}$ leer una autobiografía, hay que tomar en cuenta que la autorrepresentación es, como todas las narrativas, una re-presentación verbal selectiva de una vida y una subjetividad que depende de la memoria siempre incompleta de un individuo y de sus intereses actuales. En consecuencia, no es una imagen transparente del pasado. Para dar un ejemplo de este texto, la Irina Echeverría de 2008 habla de sí misma en femenino aun cuando se trata de su infancia y nunca menciona el nombre que sus padres le dieron al nacer "varón". La narradora-protagonista del testimonio conscientemente ejerce la opción de representarse como mujer desde el principio de la historia, declarando que "en realidad mi sentir y mi forma de ver las cosas siempre fueron femeninas. Entonces no lo tenía muy claro, ahora sí" (25). Los escritos autobiográficos constituyen una interpretación valiosa de la experiencia humana forjada en contacto con los demás y pueden leerse para entender los significados y el valor social de distintas identidades según el individuo los percibe y experimenta. Estas representaciones son especialmente urgentes cuando se trata de los sujetos que viven una experiencia de exclusión e invisibilidad debido a una identidad discriminada. En lo que sigue me concentro en los significados de la discapacidad física de Irina Echeverría más que en su identidad como una persona transexual. Sin embargo, es relevante reconocer que su experiencia de múltiples formas de la discriminación conduce a 
una comprensión amplia y profunda de los procesos de estigmatización en la sociedad mexicana.

Durante su infancia, Echeverría vive la soledad, la enajenación y la precariedad dentro de su familia a causa de su discapacidad, así como en la escuela, a causa de la política de sus padres. La insistencia de su madre en mantener la fachada de una familia "normal" significa que está prohibido hablar de la enfermedad de Irina, quien en aquel entonces es identificada por los demás como muchacho. El silencio y la negación de su realidad crean una distancia emocional insuperable con sus hermanas y un conflicto interior que se manifiesta en la rebeldía y la inconformidad. A la edad de cuatro años, vive doce meses con el cuerpo enyesado e inmóvil después de una operación en la columna vertebral, y otra cirugía desacertada le debilita la columna y las piernas. A la edad de siete, viaja con su padre a Rumanía para que le operen una pierna. Está allí ocho meses, durante los cuales casi no ve a su padre y se siente muy abandonada por su madre, quien se queda en México. Como muchas personas que de niños pasan tiempo en el hospital, Echeverría recuerda un sentido abrumador de abandono y tristeza al estar sujeto a un régimen médico que frecuentemente trata el cuerpo y sus síntomas físicos sin atender a la persona. Su historia personal contribuye como evidencia vivencial con la amplia crítica hacia el modelo médico que los estudios de la discapacidad han hecho a través de los años.

De regreso a México, sus padres la inscriben en una escuela de la llamada "educación especial", lo que más tarde ella identifica como la primera discriminación que sufre. Es decir, igual que a la activista Gabriela Brimmer dos décadas antes, en los años setenta el sistema de educación pública todavía no sabía evaluar la capacidad intelectual de los niños discapacitados, no importaba cuál fuera su condición. Echeverría comenta que, en consecuencia, "Nunca me adapté a ese sistema, fui una persona muy conflictiva en la vida fuera de la casa, me corrieron de muchas escuelas" (21). Se entiende que ella se haya sentido especialmente discriminada al ser inscrita en una escuela donde atendían a alumnos con una discapacidad intelectual, pero no le fue mucho mejor cuando la cambiaron al colegio donde estudiaba su hermana. Allí hace frente a una discriminación doble basada en su discapacidad física y el activismo político de sus padres. Ve también cómo algunos alumnos agreden a otros niños, por ser ellos más jóvenes o más débiles. Un sentido de solidaridad la convierte en "la protectora de las causas perdidas" (22) y dice "comprendí que el conflicto no nada más era mío, sino que había también un problema de aceptación de las otras partes que interactuaban en el ambiente escolar" (22-23). Es decir, sobre la base de su situación individual, la Irina joven ya percibe y se opone a la discriminación y agresión generalizadas en su sociedad en contra de los desamparados y los diferentes. 
El hecho de dirigirle la carta a su padre tiene el doble valor de hacer muy personal el mensaje y mostrar en términos muy concretos el impacto que el estigma y el odio tienen en la persona transexual y con discapacidad. En la infancia tenía una relación muy conflictiva con su padre, quien no le hacía caso, la insultaba o la castigaba a golpes por los errores o los descuidos, a veces muy menores, causados por su discapacidad física. Echeverría dice que quería tener una relación más sana con su padre, pero era imposible. La ruptura total llega cuando una hermana le cuenta al padre que su hijo se llama Irina y es mujer, y él dice que "para mí estás muerto". El tono de la carta va de enojo a tristeza, de perplejidad a acusación mientras le critica su actitud machista, le acusa por el rechazo y los abusos sufridos, y le explica en términos claros y racionales qué significa ser transexual. Más allá de su estatus como el padre biológico de Echeverría, su figura en la carta representa la rigidez y la intolerancia de una sociedad en la que los valores patriarcales y el capacitismo predominan. A través de la Carta, Echeverría insiste en ser respetada en su identidad y reclama los derechos que le corresponden como ciudadana y como ser humano. Esos derechos, todavía sin cumplir en 2008 para los discapacitados y los transexuales, incluyen el acceso al transporte y a muchos espacios públicos, así como un nuevo certificado de nacimiento corregido para dejar de ser "indocumentada" en su propio país.

Ekiwah Adler Beléndez nació en Amatlán de Quetzalcoatl, Morelos, México en 1987. De padre estadounidense y madre mexicana, no solo es bilingüe en inglés y español, sino que es bicultural. Vivió cinco años en los Estados Unidos cuando estudió en Bard College at Simon's Rock y luego en Hampshire College, donde hizo la carrera en creación literaria. Como consecuencia de haber nacido diez semanas prematuramente, Adler Beléndez vive con parálisis cerebral y también tuvo una escoliosis tan severa como para ser mortal, por la cual le operaron cuando tenía diecisiete años. La discapacidad motriz y el dolor son hechos no "superables" ni curables de su realidad, y han contribuido a formar su subjetividad, su conciencia de sí mismo y de los demás, su perspectiva crítica sobre la estigmatización de la diferencia y su poesía. Empezó a escribir cuando era muy joven, publicando su primer poemario en el año 2000. Otros cuatro aparecieron entre 2001 y 2006, pero él tomó más de una década para pensar y escribir primero en inglés, los veintiún textos del volumen inédito "Love on Wheels". Los poemas fueron traducidos al español por Kenia Cano y el mismo poeta para el

2 El poeta, en un gesto que reconoce la dimensión colaborativa de toda obra creativa, me hizo saber que tiene una deuda con su mentor Fran Quinn, quien lo acompañó en el proceso de escribir y editar este poemario. 
libro Amor sobre ruedas, próximo a salir en Editorial 17, México. Además de ser poeta, Ekiwah Adler Beléndez ha sido maestro de talleres de poesía para jóvenes con parálisis cerebral, una labor que dio fruto en una antología poética titulada Acto de presencia (2013). Dos poemas de Amor sobre ruedas ilustran cómo el poeta trata los obstáculos y los placeres que la parálisis supone para ser hijo, amante, padre y poeta. Sus textos pueden ser leídos tanto por su valor estético como por la teoría de la discapacidad que comunican. ${ }^{3}$ El primer poema "Oda a la hora del café en Amatlán" viene de la primera parte del libro, mientras que "Caminar con otro cuerpo" pertenece a la última sección. Entre el uno y el otro se desarrolla una visión siempre más compleja y matizada de su cuerpo y de los significados de su discapacidad.

"Oda a la hora del café", un poema dedicado a sus padres, retrata una escena doméstica aparentemente tranquila e idealizada, mientras poco a poco revela que hay una trampa oculta en las cómodas rutinas de la vida diaria. El poeta le ha puesto un epígrafe, "Vámonos inmóviles de viaje"; este es el primer verso de un poema de Xavier Villaurrutia, uno que Adler Beléndez recuerda y recita con frecuencia.

Vámonos inmóviles de viaje

Para ver la tarde de siempre

Con otra mirada,

Para ver la mirada de siempre

Con distinta tarde.

Vámonos inmóviles.

El epígrafe, que es una invitación, establece los parámetros temáticos de la "Oda a la hora del café" e introduce la paradoja que está en el centro de la experiencia recreada a una distancia en el tiempo. Es decir, se trata de viajar quedándose siempre en el mismo lugar; se trata también de la inmovilidad de las rutinas que en su repetición son iguales de un día a otro, mientras son siempre distintas si son contempladas "con otra mirada". "Vámonos inmóviles de viaje/para ver la tarde de siempre/con otra mirada.... El yo poético evoca la hora del café como un tiempo de compañerismo y armonía familiar. Gran parte del poema es un elogio a la vida cotidiana en familia, como el título promete. Sin embargo, mientras el acto de recordar avanza, el yo logra ver el pasado con esa "otra mirada" que Villaurrutia propone; en este caso una mirada crítica que descubre otro significado distinto en la "mañana de siempre".

3 El texto completo de los dos poemas se encuentra en el apéndice. 
El poema, de verso libre, consta de ochenta y seis versos organizados en siete secciones, y se compone de abundantes elementos intertextuales y retóricos. Es un poema narrativo con tres personajes: el padre, la madre y el yo del hijo-poeta. Es temprano en la madrugada. El padre lee en voz alta a su hijo; la madre baja la escalera y los tres pasan un rato platicando del día a día antes de separarse para emprender sus quehaceres. El espacio donde se reúnen se reduce a la mesa donde toman el café, pero el campo visual se extiende fuera de la casa hacia las montañas al otro lado del valle. En la imaginación del yo, los horizontes de su experiencia se amplían aun más hasta llegar a la ciudad ficticia de una novela del autor japonés Haruki Murakami. Las imágenes bellas y armónicas predominantes comunican un mensaje de amor y solidaridad dentro de un ámbito familiar íntimo y seguro. No obstante, esta imagen positiva queda suavemente cuestionada y subvertida al final del poema y, al leer los últimos versos, los lectores pueden darse cuenta de que algunos elementos subversivos han sido plantados como pequeñas semillas verbales a través del texto y no solo se incorporan al final. El juego de los tiempos verbales, el valor polisémico de los signos "silencio" y "palabras" y las referencias intertextuales transmiten una visión nostálgica y a la vez perspicaz y crítica del pasado. La crítica implícita del significado de la discapacidad para el joven poeta demuestra una teorización realizada a partir de la experiencia personal con una proyección hacia una experiencia colectiva.

El marco temporal abarca dos momentos de vida vistos con tres miradas. Primera mirada: la hora del café recreada en toda su inmediatez, como si ocurriera en el presente del hablante. Los primeros versos son: "Llegamos de nuevo/a la hora del café./Mi padre madruga./Prende una lámpara/hasta que el sol alumbra las páginas". Seis de las siete secciones del poema se narran así, en presente. La sexta sección concluye con la primera y única alusión a una discapacidad física. Dice: "Tendré ganas de salir de la casa solo,/de vagar en el mercado al cielo abierto en Tepoztlán/pero el empedrado agrietado y mis piernas tiesas/detendrán mis pasos". Segunda mirada: En sección siete, otro momento irrumpe en el texto, un momento pasado posterior a la escena aparentemente actual de la hora del café: "Años después entendí/que yo mismo me había atrapado/en esta cárcel hermosa". De acuerdo con el poema de Villaurrutia, en algún momento "años después", el yo poético ve la mañana de siempre con otra mirada y la casa concebida como el lugar ameno clásico es transformada en una cárcel no solo física sino psicológica. La opresión y la estigmatización internalizadas limitan la libertad y los posibles futuros que el yo lírico anhela. Tercera mirada: La hora del café vuelve en los últimos versos y la rutina se reafirma, pero ahora es narrada no en presente sino en imperfecto, y su significado final ha viajado lejos de su punto de partida: "Mi madre derretía mantequilla sobre mi pan.../Mi padre abría en 
silencio la miel.../Después de tantas palabras/el silencio comenzó a reunirse en las cubetas/de lo que aún no habíamos dicho".

Los términos "silencio" y "palabra" son signos polisémicos que adquieren significados contradictorios a través del poema. Esta polisemia capta el movimiento desde una visión idealizada de la rutina familiar hacia una más crítica. Al principio, el silencio caracteriza al padre cuando el yo lo describe así: "Tan cómodo con su propio silencio/fluye junto a ese río/en el que pocos se adentran./Yo lo acompaño ahí/con mi propio silencio". Su padre es un hombre de "frases parcas" pero generoso con el pan que sirve "rebanada tras rebanada" sobre la mesa. Este es el silencio noble de las aguas tranquilas y profundas, como cuando decimos de una persona que "still waters run deep". Las "palabras" que forman parte de la conversación compartida entre los tres sujetos también tienen una connotación positiva inicialmente como en este verso que las asocia metafóricamente con el agua y las flores: "Nuestras palabras riegan los lirios de la conversación". En cambio, los versos finales conducen a otra conclusión sobre el valor del silencio y la conversación: "Después de tantas palabras/el silencio comenzó a reunirse en las cubetas/de lo que aún no habíamos dicho". El habla que era tan vital como el agua que riega un jardín, se reduce a "tantas palabras", terminando en un silencio que es una negación, un no haber dicho lo que se debiera. La falta de comunicación sobre temas no explícitos en el poema aumenta la sensación de vivir en una cárcel hermosa con deseos de ser libre.

En la sección siete, la metáfora de la "cárcel hermosa" transfiere los significados de encierro y falta de libertad al espacio doméstico, que es un refugio pero también un lugar de protección o sobreprotección que limita. La imagen nos remite a versos anteriores que podrían pasar desapercibidos en una primera lectura, pero se vuelven relevantes en una relectura del poema. La sección dos comienza con otra metáfora: "Desde mi ventana/las montañas son gigantes deformes/que me protegen. ¿De qué?" ... "Hablan en lengua de señas/que no sé interpretar". En estos versos, las montañas - personificadas y discapacitadas- ofrecen una protección y hablan una lengua incomprensible para el yo poético. Más tarde, él logra interpretar el significado de esta protección carcelaria cuando se refiere a su casa como "esa cárcel hermosa". Sin embargo, la lengua de señas que no sabe interpretar sigue siendo un misterio, quizás como el potencial positivo de su propio cuerpo que sigue sin apreciar en este poema. La referencia intertextual a la novela Hard-Boiled Wonderland and the End of the World de Haruki Murakami en la sección tres también trata la idea del encierro que protege y limita, e introduce el deseo de sentirse libre. Mientras su padre lee la novela en voz alta, su hijo "ve" con los ojos cerrados las bestias de la historia y piensa: "En vano tratan de escaparse/del muro invisible que las retiene”. Solo en retrospectiva, los lectores 
pueden comprender en qué medida el yo poético se identifica con las criaturas fantásticas de Murakami.

En "Oda a la hora del café", la idealización del pasado predomina hasta llegar a las últimas estrofas, donde el yo poético consolida ideas introducidas poco a poco en secciones anteriores y concluye con una imagen alternativa y crítica de la casa, la rutina, la conversación y el silencio. Al cuestionar el significado de los espacios y las relaciones de dependencia que protegen al sujeto con "cuerpo tieso", el poema interpreta la experiencia de los que se movilizan en silla de ruedas en un pueblo pequeño de México y enfrentan los muchos obstáculos a su libre movimiento. Esta interpretación poética en primera persona puede contribuir con una teorización más amplia de la discapacidad como un fenómeno no solo individual y corpóreo sino social y arquitectónico.

Como el título del manuscrito "Amor sobre ruedas" indica, el amor, el deseo y la sexualidad son temas centrales del poemario y el orden de los textos determinado por el poeta traza una trayectoria desde el desencuentro y la frustración en el amor, hacia la plenitud de los deseos más íntimos y la reconciliación con su diferencia corpórea. Es un proceso que incluye la experiencia erótica y la paternidad, así como una nueva apreciación del cuerpo ya no tieso sino ágil para el amor. El poema "Caminar con otro cuerpo", que está dividido en tres secciones, capta tres momentos de esta trayectoria. Comienza exponiendo y criticando las actitudes discapacitantes que determinan el tan privilegiado acto de caminar erecto y en los dos pies, para terminar celebrando el amor y el cuerpo capaz de "caminar" de otro modo. La primera parte del poema es una protesta contra el régimen de la terapia física, la futilidad de los esfuerzos por caminar con andador y la tiranía de la normalidad. "Mi pierna en una prótesis pesada y recta./ La otra demasiado lánguida y pivoteando/Empujé mi andador con paso de pirata./'Haz ejercicio y aprenderás a caminar/Como todos' dijo todo el mundo". Caminar como todos, ser y estar como todos es el mensaje comunicado de mil maneras por un mundo que no se adapta a la diferencia. Luego, en silla de ruedas con su pequeño hijo tomado de la mano, el yo poético se da cuenta de que "Esto también/Es Caminar: ¡El amor moviéndose en el tiempo!”.

En la segunda parte del poema, el yo ve a su hijo jugar y brincar, luego resbalarse y caerse. Padre e hijo aprenden que tanto el deseo de volar como la inevitable atracción de la gravedad constituyen el cuerpo en movimiento. En las últimas estrofas, de tono íntimo y ligero, el yo poético interpreta la intimidad erótica como un caminar con otro cuerpo. Si antes el girar en silla de ruedas se celebra como un modo de caminar más válido y más libre que ir empujando "el andador con paso de pirata", ahora estar en la cama, acariciando a su amada con dedos que leen el texto secreto de su cuerpo desnudo, "Esto 
también es caminar:/Estar firmemente erecto". Juega con los significados de "estar erecto" para burlarse de la militancia de los que intentan rehabilitar al otro diferente y para burlarse del privilegio de "caminar vertical". "Obstinadamente horizontal me opongo/¡Esta vida no es una vana marcha militar!” Es un acto de amar y de hacer el amor, un acto cuya capacidad para el placer excede los límites del cuerpo y "la velocidad de nuestros pasos". Concluye su crítica del capacitismo predominante y su testimonio de otros modos de movilizarse amorosamente por el mundo afirmando que "caminar es más que mover los pies". En nuestras sociedades donde la sexualidad es todavía un tema tabú y es otro sitio de exclusión para los que viven con una discapacidad, vale leer la poesía de un joven que se atreve a dar voz a su capacidad erótica y defender el derecho a una vida sexual o a la "ciudadanía sexual", para usar el término formulado por Tobin Siebers (Disability Theory 148-149), que es otro paso hacia la plena realización de la subjetividad.

En el epílogo de "Amor sobre ruedas", Ekiwah Adler Beléndez expresa en prosa los conocimientos que emergen de su poesía, y el poeta se proyecta más allá de la experiencia personal hacia una visión global de lo que viven muchas personas discapacitadas en México. Reafirma que la rehabilitación y la promesa de poder aprender a caminar, o ver u oír pueden ser una trampa si significa que se vive siempre esperando otro cuerpo futuro e ignorando "los milagros y los peligros" del cuerpo con que se nació. Confiesa su propia tendencia a escaparse del cuerpo "deficiente" o insuficiente por medio de la imaginación y la creación poética, una tendencia que está en conflicto con la necesidad de aceptar los milagros y los peligros que ese mismo cuerpo hace posible: ser hijo, amigo, amante, padre, poeta. La poesía es una suerte de paracaídas con la cual se ha lanzado a la realidad, cayéndose no sin riesgo pero con la esperanza de un aterrizaje seguro.

La Carta a mi padre de Irina Echeverría y la poesía de Ekiwah Adler Beléndez muestran que una lectura de los escritos autobiográficos de la discapacidad en el Sur global como una forma de teoría articulada en primera persona, contribuye con la elaboración de una visión más compleja y matizada de los significados de la discapacidad para el individuo y para la comunidad. Todo ello conduce a un mayor aprecio del conocimiento producido por sujetos que viven la realidad del mundo mayoritario. 


\section{Apéndice}

\section{Oda a la hora del café en Amatlán de Quetzalcóatl}

Para mi padre y mi madre

\section{"Vámonos inmóviles de viaje" -Xavier Villaurrutia}

\section{1}

Llegamos de nuevo

a la hora del café.

Mi padre madruga. Prende una lámpara

hasta que el sol alumbra las páginas.

Tan cómodo con su propio silencio

fluye junto a ese río

en el que pocos se adentran.

Yo lo acompaño ahí

con mi propio silencio

o lo interrumpo con una procesión latosa

de dimes y qué piensas...

y entonces gotean sus palabras.

2

Desde mi ventana

las montañas son gigantes deformes

que me protegen. ¿De qué?

Un solo rostro con miles de muecas esculpidas

en musgo, piedra y lodo. Hablan en lengua de señas

que no sé interpretar.

Imagino en duermevela

el cuerpo eterno del cielo.

Sueño pájaros azules

paridos por una luz plateada.

Olvido otra vez las manchas

de mis dientes sucios y las del periódico

mientras ambos requieren

mi urgente atención. 
Mi padre abre

una novela de Murakami

me lee en voz alta, cierro los ojos y veo

bestias con cuernos, rojas durante el otoño

$\mathrm{y}$ albinas en el inverno.

En vano tratan de escaparse

del muro invisible que las retiene.

La gata dibuja un halo de sonido

alrededor de nuestro rito de lectura

para que siga intacto un rato más.

4

Más tarde, mi madre

cubierta de los copos del desvelo

desciende la escalera con aires de realeza

en su pijama violeta y gastada.

Nos besa, no puede tomar otro café

que el de La Selva. Con su Leche Clavel

y un plátano casi verde que debe emitir

un chasquido al pelarse.

Un haz de luz

la corona entre bostezos.

5

Ella y yo hablamos

de la alabanza que cura

y de las suculentas historias sexuales

de nuestros vecinos.

En esta casa

el invierno, la primavera y el verano

circulan la misma mesa para encontrarnos

todavía sentados en nuestros lugares

apenas notando el tiempo.

Mi padre con su trino de frases parcas

pone rebanada tras rebanada

de pan de amaranto sobre la mesa.

Nuestras palabras riegan los lirios de la conversación. 
Volveremos al fin

a nuestros quehaceres; mi madre

acompañará el bienestar de un paciente.

Mi padre se agachará para mudar la arúgula

que se desborda en la maceta. Yo voltearé

una línea o dos al derecho y al revés

hasta acomodar un verso.

Las alegrías y los duelos de nuestros oficios

son creaturas dormidas que pronto

despertarán hambrientas.

Tendré ganas de salir de la casa solo,

de vagar en el mercado a cielo abierto en Tepoztlán,

pero el empedrado agrietado y mis piernas tiesas

detendrán mis pasos.

7

Años después entendí

que yo mismo me había atrapado

en esta cárcel hermosa.

Pero en aquellos tiempos

encontrar una solución

parecía tan inverosímil como toparse

con una de las bestias de Murakami

en el pueblo.

Mi madre derretía mantequilla sobre mi pan...

Mi padre abría en silencio la miel...

Después de tantas palabras

el silencio comenzó a reunirse en las cubetas

de lo que aún no habíamos dicho. 


\section{Caminar con otro cuerpo}

1

Caminar era una pista amarilla de cemento.

El color del pasto en la sequía. Hacer ejercicio

Era andar rígido y flojo. Esperar un milagro

Que pudiera componerme para siempre.

Mi pierna en una prótesis pesada y recta.

La otra demasiado lánguida y pivoteando

Empujé mi andador con paso de pirata.

"Haz ejercicio y aprenderás a caminar

Como todos" dijo todo el mundo. Una y otra vez

La misma trama. El mismo tramo de tierra. La sensación

De moverse sin avanzar. Ahora mi hijo de tres años

Me toma de la mano, la jala con suavidad y ajusta su paso

Giro en mi silla de ruedas a su lado. Esto también

Es Caminar: ¡El amor moviéndose en el tiempo!

\section{2}

Nuestro hijo brinca con los pasos alegres

$\mathrm{Y}$ apenas musicales de los Chinelos

Aprende a bailar antes de poder hablar

Hombros y pies: pasito pa' delante y pasito para atrás.

Le sonríe a los juguetes: la gravedad de lo que cae

Desde las grandes alturas de las cajas. Los levanta

Y se paran de nuevo erguidos por otro instante

En la alegría secreta de los héroes que chocan.

Batman se resbala y cae,

Detrás de la máscara, nuestro hijo llora y grita

Su madre lo levanta en brazos

Y el llanto entre sueños se vuelve risa.

Caminar es volar y aprender a caer

Dejar que las lágrimas y las carcajadas resuenen.

3

Debajo del vestido blanco de mi amada

Navega una palabra secreta. Nos tomamos

De las manos en la cama y el cuervo oculto

En su cabello, cuenta a graznidos el escándalo 
Que mis dedos han leído. Esto también es caminar:

Estar firmemente erecto. El caminar vertical es demasiado débil.

Obstinadamente horizontal me opongo

¡Esta vida no es una vana marcha militar!

Aprendemos a movernos con gran finura

Cada vez más ágiles en la carrera desbocada

De nuestros cuerpos. En cada latido y caricia

Excedemos la velocidad de nuestros pasos.

Este caminar es más que mover los pies

Es este espacio delicado donde se encuentran los amantes.

\section{Bibliografía}

Adler Beléndez, Ekiwah (comp.). 2013. Acto de presencia: Antología poética, Jiutepec, Morelos: Con Nosotros A.C.

Adler Beléndez, Ekiwah. "Amor sobre ruedas", Ciudad de México: Editorial 17. [en preparación]

Antebi, Susan. 2009. Carnal Inscriptions: Spanish American Narratives of Corporeal Difference and Disability, New York: Palgrave Macmillan.

Antebi, Susan/Jörgensen, Beth E. (eds.). 2016. Libre Acceso: Latin American Literature and Film through Disability Studies, Albany: State University of New York Press.

Checa, Julio/Hartwig, Susanne (eds.). 2018. ¿Discapacidad? Literatura, teatro, y cine hispánicos vistos desde los disability studies, Berlin: Peter Lang.

Couser, G. Thomas. 2009. Signifying Bodies: Disability in Contemporary Life Writing, Ann Arbor: University of Michigan Press.

Echeverría, Irina. 2008. Carta a mi padre: Testimonio de una persona transexual con discapacidad, Ciudad de México: Conapred.

Fraser, Benjamin. 2013. Disability Studies and Spanish Culture: Films, Novels, the Comic and the Public Exhibition, Liverpool: Liverpool University Press.

Fraser, Benjamin. 2018. Cognitive Disability Aesthetics: Visual Culture, Disability Representations, and the (In)Visibility of Cognitive Difference, Toronto: University of Toronto Press.

Grech, Shaun. 2015. Disability and Poverty in the Global South: Renegotiating Development in Guatemala, New York: Palgrave Macmillan.

Grech, Shaun/Goodley, Dan. 2012. "Doing Disability Research in the Majority World: An Alternative Framework and the Quest for Decolonizing Methods", en: Journal of Human Development, Disability, and Social Change 19 (2): $43-$ 55. 
Janzen, Rebecca. 2015. The National Body in Mexican Literature: Collective Challenges to Biopolitical Control, New York: Palgrave Macmillan.

Meekosha, Helen. 2011. "Decolonising Disability: Thinking and Acting Globally", en: Disability and Society 26 (6): 667-682.

Minich, Julie Avril. 2014. Accessible Citizenships: Disability, Nation, and the Cultural Politics of Greater Mexico, Philadelphia: Temple University Press.

Mintz, Susannah. 2007. Unruly Bodies: Life Writing by Women with Disabilities, Chapel Hill: University of North Carolina Press.

Miranda Galarza, Beatriz. 2018. Nuestra historia no es mentira: Vivir con "lepra" en Ecuador, Ciudad de México: Colección Diecisiete.

Prout, Ryan. 2008. "Cryptic Triptych: (Re)Reading Disability in Spanish Film 1960-2003”, en: Arizona Journal of Hispanic Cultural Studies 12: 165-187.

Siebers, Tobin. 2008. Disability Theory, Ann Arbor: University of Michigan Press. 
Alejandra M. Aventín Fontana

Universidad Carlos III de Madrid

\title{
(Im)pactos de la poesía en la representación de la diversidad funcional. "Peregrina de mí he ido hacia la que duerme en un país al viento"': la palabra integradora de Alejandra Pizarnik
}

\author{
Quiere, quiere delirar, porque en el delirio la palabra \\ brota en toda su pureza originaria.
}

María Zambrano ${ }^{2}$

\begin{abstract}
The purpose of this work is to offer an analysis of the representation of functional diversity in well-known Argentinian writer Alejandra Pizarnik's poetry. All throughout her life, she had to face a severe mental disorder that had an impact on her writing signed by a profound feeling of being foreign that led her to turning poetry into a refuge and a mirror that may have led her to apprehend the world and calm the pain. Her writing stands as a valuable representation of functional diversity not only because of its honesty, sensitivity and transgression but also due to her ability to integrate the modern poetry tradition in her work brilliantly.
\end{abstract}

Keywords: representation, functional diversity, poetry, body, pain

El estudio de la representación de la diversidad funcional en la poesía hispánica contemporánea es una tarea compleja pero impostergable hoy. En su artículo "Disability in the Hispanic World: Proposals and Methodologies", publicado en Arizona Journal of Hispanic Studies en el año 2013, Encarnación Juárez-Almendros subraya el crecimiento de los disability studies y su aplicación a las humanidades, pero pone de relieve su escasez en el hispanismo (Juárez-Almendros 2013); una escasez que continúa siendo una realidad

1 Versos de la composición "Caminos del espejo" del poemario Extracción de la piedra de la locura (1968) (Pizarnik 2007: 243). Para Gely, por ser ramo en el que resguardarme del temblor, gracias.

2 Cita perteneciente a la obra Filosofía y poesía de María Zambrano (1997: 53-54). 
incontestable en el ámbito académico de la poesía hispánica hoy y un reto pendiente ${ }^{3}$.

La presente ponencia aspira a estudiar su representación en la obra poética de la escritora Alejandra Pizarnik (Avellaneda, 1936-Buenos Aires, 1972) con el propósito de contribuir a la fundación de una cartografía de la diversidad funcional que permita reflexionar sobre imaginarios poéticos de nuestra historiografía literaria, signados por su presencia -con las dicotomías y los dilemas que caracterizan su difícil sinergia- con el fin de reflexionar y rastrear representaciones emancipadoras que promuevan en palabras de la profesora Susanne Hartwig, "un concepto de identidad como diálogo, negociación y performance" (Hartwig 2018: 16) en el marco de la modernidad. Nótese que entendemos la posmodernidad - momento en el que se articula nuestra mirada crítica-, al igual que Matei Calinescu, como una de las caras de la modernidad (Calinescu 1991). ${ }^{5}$

Se trata de poner de manifiesto la importancia de las representaciones que se circunscriben al ámbito de lo poético - un género literario capital para comprender la identidad en Hispanoamérica a partir del periodo poscolonial y la forja de las nuevas naciones- en la literatura hispanoamericana contemporánea. No olvidemos que el primer movimiento literario netamente hispanoamericano -tal y como apunta José Olivio Jiménez en el estudio crítico preliminar de su imprescindible Antología crítica de la poesía modernista hispanoamericana- fue el modernismo que encuentra en los versos del nicaragüense Rubén Darío, su génesis y su cima (Olivio Jiménez 1994: 17).

3 La propuesta crítica que planteamos tiene en consideración los siguientes trabajos que abordan la representación de la diversidad funcional en la poesía hispánica contemporánea y propone un diálogo con estos: "Negotiating the Geographies of Exclusion and Access. Life Writing by Gabriela Brimmer and Ekiwah Adler-Beléndez" de la profesora Beth Jörgensen y "La cara que me mira. Demythologizing Blindness in Borges's Disability Life Writing” de Kevin Goldstein, ambos textos incluidos en el volumen Libre Acceso. Latin American Literature and Film through Disability Studies (Antebi/Jörgensen 2016), así como los siguientes estudios sobre su representación en la literatura y la cultura hispánicas contemporáneas: la sección "Disability Studies in the Hispanic World" publicada en Arizona Jorunal of Hispanic Cultural Studies (17, 2013), Fraser (2013), (Marr 2013), (Antebi/Jörgensen 2016) y (Hartwig/Checa 2018).

4 Al igual que Javier Romañach y Manuel Lobato contemplamos la diversidad funcional como un término que incide en el valor de la diferencia y el enriquecimiento de quien lo porta y lo que al mundo aporta (Romañach/Lobato 2005).

5 Calinescu señala que la modernidad posee cinco caras: el modernismo, la vanguardia, la decadencia, el kitsch y la posmodernidad (Calinescu 1991). 
En la "Introducción" del volumen titulado Libre acceso. American Literature and Film through Disability Studies, Susan Antebi y Beth E. Jörgensen insisten en que "Disability also intersects with factors of class, race and gender to prompt critical reflection on the complexities of the social and cultural construction of disability as well as human beings inescapably embodied experience of the world" (Antebi/Jörgensen 2016: 8) ${ }^{6}$ de manera particular en Hispanoamérica, cuestiones que estarán muy presentes en el análisis de la representación de la diversidad funcional en la obra literaria, en general, y poética, en particular, de Alejandra Pizarnik en las líneas que siguen.

La elección de la poesía de Alejandra Pizarnik no es baladí. En primer lugar, porque se trata de una escritora cuya contribución a la poesía hispánica contemporánea ha sido ampliamente estudiada y valorada por la academia, tal y como pone de relieve la vasta masa crítica que existe sobre su obra, difundida en prestigiosos foros. En el año 2008, esto es, hace más de una década, la académica Patricia Venti publicaba en la editorial madrileña Centro Editores, el volumen titulado Bibliografía completa de Alejandra Pizarnik que incluía, ya entonces, más de cincuenta páginas de referencias bibliográficas de crítica sobre su obra literaria (Venti 2008).

En segundo lugar, porque el propósito de las reflexiones críticas vertidas es plantear el estudio de la representación de la diversidad funcional en los versos pizarnikianos en un marco que contemple el diálogo con el discurso académico existente. Consideramos que esto permitirá poner de relieve el enriquecimiento derivado de la presencia de la diversidad psíquica y su fecundo impacto en el proceso de la creación poética.

Esperamos que nuestra aportación a la fundación de esta cartografía a través de este ejercicio crítico, contribuya a subsanar la fragmentación existente en las arenas de la representación de la diversidad funcional que ha de comprender su pasado para afrontar y profundizar en el presente. Y que debe aspirar en última instancia, a cumplir su destino de esencialismo estratégico (Spivak 1988: 205) en un futuro, esperemos que no muy lejano, al contribuir con sus aportaciones

6 En este contexto, el cuerpo - eje central de nuestro ejercicio crítico al igual que el de Antebi/Jörgensen (2016: 8) - tal y como apunta Alain Corbain, coautor y director de Historia del cuerpo (II). De la Revolución Francesa a la Gran Guerra - se caracteriza por "la porosidad entre el cuerpo sujeto y el cuerpo objeto y entre el cuerpo individual y colectivo [que] se ha refinado y complicado en el siglo XX". Y así, este es entrevisto como "una ficción, un conjunto de representaciones mentales, una imagen inconsciente que se elabora, se disuelve, se reconstruye al hilo de la historia del sujeto, por mediación de los discursos sociales y de los sistemas simbólicos" (Corbain 2005: 17). 
a "promover, proteger y asegurar el goce pleno y en condiciones de igualdad de todos los derechos humanos y libertades fundamentales a todas las personas con discapacidad y promover el respeto de su dignidad inherente", propósito fundamental de la Convención Internacional sobre los Derechos de Personas con Discapacidad de las Naciones Unidas, firmada y ratificada por España e Hispanoamérica en $2007 .^{7}$

Es la voz de Alejandra Pizarnik una de las grandes cimas de la poesía hispánica contemporánea. El valor de su legado reposa en su voluntad por fundar valientemente su devenir en la errancia asumida y el relato sacrificial, frutos de su resistencia a la asunción de la insuficiencia del lenguaje poético en la segunda mitad del siglo XX. Nada Kavčič afirma: "la relación que el sujeto tiene con el lenguaje [es] la que define las tensiones principales de la poética de Pizarnik" e insiste en que "la poeta determina su destino poético a través de la imposibilidad del lenguaje” (Kavčič 2017: 217).

Ahora bien, esta imperturbable voluntad reposa en un sentimiento de extranjería, "marca o huella fundacional de su poesía" y presencia constante en su vida para Cristina Piña (2005: 53); y "eterna ausencia en que se cifra el oficio de vivir" para el profesor Vicente Cervera Salinas (2010: 113). Y así, frente al mundo degradado y el horror de la civilización -cifrados en la imagen de la vida como caída - la poesía es erigida por Pizarnik como la única opción salvadora; una herida metafórica, esta percepción del mundo que la acompañó desde la adolescencia y cuyo pálpito inconmensurable evidenció su diferencia al crecer en dimensión y en dolor con la cronificación de las perturbaciones mentales experimentadas por la argentina aun después de recurrir al psicoanálisis -su poemario La última inocencia $(1956)^{8}$ está dedicado a uno de los dos psicoanalistas que la trataron, León Ostrov, el otro fue Enrique Pichon-Rivière- y al internamiento esporádico; y que se convertirían en un cuadro depresivo agudo y posteriormente, tal y como apunta Patricia Venti, en una inestabilidad que junto con el uso y el abuso prolongado de pastillas devendría en un trastorno próximo

7 Naciones Unidas, "Convención Internacional sobre los Derechos de las Personas con Discapacidad”, en https://www.un.org/esa/socdev/enable/documents/tccconvs.pdf [15-01-2019]

8 Fue este el segundo poemario publicado de la escritora argentina. El primero de todos, La tierra más ajena lo sería en 1955. A este le sucedieron: La última inocencia (1956), Las aventuras perdidas (1958), Árbol de Diana (1962), Los trabajos y las noches (1965), Extracción de la piedra de locura (1968), El infierno musical (1971) y Textos de Sombra $y$ últimos poemas, volumen que vería la luz en 1982. 
a la esquizofrenia paranoide (Venti 2008: 193)․ Se empiezan así a suceder los intentos de suicido cada vez menos espaciados en el tiempo, hasta que llega el fatal desenlace en la madrugada del 25 de septiembre de 1972, cuando Alejandra decide poner fin a su vida: treinta y seis años después de su nacimiento con cincuenta pastillas de Seconal sódico (Piña 2005: 14), Pizarnik se despedía del mundo. En el pizarrón de su cuarto de trabajo se podía leer su último testimonio vital y poético, fundidos ya con trágicas consecuencias en uno solo:

criatura en plegaria

rabia contra la niebla

Escrito

En

El

Crepúsculo contra

la

opacidad

no quiero ir

nada más

que hasta el fondo

oh vida

oh lenguaje

oh Isidoro (Venti 2005: 200)

Su vida y su obra clausuran definitivamente la posibilidad de la aprehensión del mundo y sus misterios a través de la poesía -entrevisto como último reducto para la espiritualidad y la trascendencia en el siglo XIX-, impulso que signó predominantemente el quehacer vital y poético de la modernidad literaria -tal y como apunta Octavio Paz en Los hijos del limo (Paz 1986: 36)- y que encuentra en la patria imaginaria forjada por los versos de los románticos alemanes, los simbolistas franceses y el surrealismo francés un espejo y un camino que la autora de Extracción de la piedra de la locura transita con convicción y valentía en busca de algo que se evidencia como imposible: el hallazgo de la palabra prima, el canto primigenio y el verbo ancestral, tal y como apuntan Cristina Piña (1999: 93), Nuria Calafell (2007: 89) o Sarah Martín (2007: 69) que permitirían a Alejandra -así lo mantuvo casi hasta el final- revestir el mundo de la inocencia perdida al cruzar la puerta, el umbral que la separaría del jardín edénico de la infancia y conquistar así un lugar en el mundo. Sin embargo, tal y como revela

9 Cabe mencionar que ese discurso de extranjería en el que ahondaremos se ve reforzado por un sentimiento de diferencia a causa de algunos problemas de salud física que acompañarían a Alejandra: la tartamudez, el asma y el dolor de espalda crónico. 
la composición "Como agua para una piedra" la tarea es ardua y la garantía de éxito imposible:

quien retorna en busca del antiguo buscar

la noche se le cierra como agua sobre una piedra

como aire sobre un pájaro

como se cierran dos cuerpos al amarse. ${ }^{10}$ (Pizarnik 2007: 237)

Sin embargo, no fue precisamente casi hasta final tampoco cuando esta fusión entre la vida y la obra, este hacer "el cuerpo del poema con mi cuerpo", célebres versos de la argentina incluidos el poema "El deseo de la palabra" que encontramos en El infierno musical (Pizarnik 2007: 269), revela en intervalos de lucidez, el extraordinario peligro que corría. Leemos en una entrada de su diario fechada el 15 de abril de 1961: "Mi vida perdida por la literatura a causa de la literatura. Por hacer de mí un personaje literario en la vida real fracaso en mi interés de hacer literatura con mi vida, pues ésta no existe" (Pizarnik 2016: 405), consideración que adquiría un talante de mayor gravedad aún en una entrada previa fechada el lunes, 21 de abril de 1958 también de su diario: "No confundir la irrealidad poética con la irrealidad neurótica" (Pizarnik 2016: 238).

Esta última aserción ilustra la correspondencia existente entre el impulso por acallar el dolor que emana del implacable sentimiento de extranjería, la elección de la poesía de los románticos alemanes -muy en especial, Novalis y Friedrich Hölderlin- y principalmente de los simbolistas franceses -Charles Baudelaire, Arthur Rimbaud y Stéphane Mallarmé- que resulta devastadora, ya que no solo no cumple su cometido, sino que prolonga el tamaño de la herida nacida de la

10 Esto versos pertenecen al poema "Como agua sobre una piedra" que podemos encontrar en Extracción de la piedra de la locura y que ya advierten lo inevitable. Con gran acierto María Negroni sentencia en su ensayo El testigo lúcido. La obra de sombra de Alejandra Pizarnik: “Tras el esfuerzo -agotador- el espejo de las analogías se rompe, se deshace en un galimatías. No hay unión. Ni amorosa, ni entre el ser humano y el mundo, ni entre el lenguaje y las cosas. No hay más que pérdida y aferramiento a la pérdida como modo, en última instancia impotente, de suprimir la escisión. Al final no queda más que una fiesta desfigurada”. Consideración a la que suma esta reveladora reflexión que compartimos: "En este sentido, la poética de Pizarnik, que va del lirismo al derrumbe lingüístico, sin alejarse del tempo musical de la melancolía ni del telón de fondo de la noche romántica, es crucial para pensar la poesía como género dentro del contexto de la sensibilidad contemporánea. Entre el silencio y la procacidad, entre la ablación y las muecas de los significantes desatados, yendo y viniendo de un registro a otro por mecanismos de intratextualidad, robo y autocensura evidentes, esta obra obliga a reformular, una vez más, como cuestiones candentes, los vínculos entre poesía y silencio; represión y canon; carencia y ostentación; tristeza, crimen y estética" (Negroni 2003: 19). 
caída al incluir en su geografía y extensión la diversidad psicológica que pronto se evidencia como irreversible y fatal en su vida.

Y es que, tal y como Cristina Piña apunta estos escritores a los que Alejandra había tomado como modelo poético y vital "encarnan similar concepción de la literatura que absolutiza la dimensión de la creación poética y que la hace coincidir en un solo instante de incandescencia con la vida" (Piña 2005: 87). Precisamente, la ya citada composición "El deseo de la palabra" ilustra su arraigo en la poética pizarnikiana y la fatal consecuencia que no es otra que el desdoblamiento primero y la multiplicidad que acompañó a su afección psicológica, posible gracias a la fusión entre vida y poesía y del cuerpo objeto y el cuerpo sujeto con el cuerpo textual que se funden en un único territorio discursivo. Es este uno de los valores fundamentales de su imaginario que permite al lector revivir la fragmentación derivada de la diversidad psíquica que recoge así, gracias a una escritura próxima además a la evocación, la asociación y una compleja y depurada sintaxis de imágenes ${ }^{11}$ :

La noche, de nuevo la noche, la magistral sapiencia de lo oscuro, el cálido roce de la muerte, un instante de éxtasis para mí, heredera del jardín prohibido.

Pasos y voces del lado del jardín prohibido. No vayas a creer que están vivos. No vayas a creer que no están vivos. En cualquier momento, la fisura en la pared y el súbito desbandarse de las niñas que fui. [...]

En la cima de la alegría he declarado acerca de una música jamás oída. ¿¿Y qué? Ojalá pudiera vivir solamente del éxtasis, haciendo el cuerpo del poema con mi cuerpo, rescatando cada frase con mis días y con mis semanas, infundiéndole al poema mi soplo a medida que cada letra de cada palabra haya sido sacrificada en las ceremonias del vivir. (Pizarnik 2007: 271-272)

Tal y como el propio poema nos muestra en un discurso en el que lo onírico rige la atmósfera, la poeta, "heredera del jardín prohibido" se desdobla para

11 La lectura de la obra literaria Alejandra Pizarnik atendiendo a su biografía ha sido objeto de los más enardecidos debates académicos. Nuestra propuesta crítica se adscribe a la de aquellos estudiosos que consideran que la obra poética de Pizarnik refleja en el texto la experiencia de la vida lo que conlleva establecer un nexo entre el autor y el texto. La obra editada por Cristina Piña publicada en el año 2015 con el título En la trastienda del lenguaje: Nueve miradas de la escritura de Alejandra Pizarnik constata este viraje definitivo en un volumen que recoge los trabajos de destacadas intelectuales de diferentes países: Carlota Caulfield, Dores Tembrás, Ivonne Bordelois, Melanie Nicholson, Mariana Di Ció, Paulina Daza, Dores Tembrás y Clelia Moure y la propia Cristina Piña. Tal y como apunta esta última en el volumen: "la plasmación de su vida según un ideal poético tomado de la literatura es una textualización o literalización de la propia vida" (Piña 2015: 49). 
interpelarse a sí misma a través de una aserción que se encuentra articulada fuera de toda lógica. Leemos: "No vayas a creer que están vivos. No vayas a creer que no están vivos" al referirse a "las voces y los pasos" -metonimias inquietantes de los difuntos; para a continuación, incorporar un tercer desdoblamiento de ella misma que resulta cuanto menos inquietante y que encontramos en la siguiente línea: "En cualquier momento, la fisura en la pared y el súbito desbandarse de las niñas que fui”. Como si de pájaros se trataran, la poeta nos narra que las niñas que fue se desbandan por la fisura de la pared, imagen inquietante, pero de extraordinaria belleza.

En otras ocasiones, el desdoblamiento aspira a nombrar aquello que ella siente ajeno a su persona y que mora en su interior acechante como una amenaza insalvable, como la única y verdadera herida:

¿Qué bestia caída de pasmo

se arrastra por mi sangre

y quiere salvarse?

He aquí lo difícil:

caminar por las calles

y señalar el cielo o la tierra. (Pizarnik 2007: 78) ${ }^{12}$

Pero detengámonos por el momento y dejemos el relato de esa herida a través de la que lentamente se desangrará la poeta -y que representa la incuestionable presencia de la diversidad psíquica ya no como patología sino como identidad, esto es, incurable y definitiva - para posar nuestra atención en la caída que a menudo aparece en el discurso poético de Alejandra Pizarnik forjada a partir del cultivo de la imaginación aérea. Sin embargo, a diferencia del aire puro, "conciencia del instante libre, de un instante que abre un porvenir", tal y como apunta Gaston Bachelard en El aire y los sueños (Bachelard 2003: 171), su presencia se concreta en un aire enrarecido transitado por el pájaro o los pájaros, símbolo central de la existencia presentida como lo extranjero y portador del oscuro presagio que no es sino el destino inexorable de la vida entrevista desde la verticalidad: la muerte. En el poema "Origen" de La última inocencia leemos:

Hay que salvar al viento

Los pájaros queman el viento

en los cabellos de la mujer solitaria

que regresa de la naturaleza

y teje tormentos

Hay que salvar al viento (Pizarnik 2007: 52)

12 El poema "La única herida" está incluido en el poemario Las aventuras perdidas. 
Así pues, analizar la representación de la diversidad funcional en la poesía de Alejandra Pizarnik, comprende transitar la geografía del sentimiento de extranjería que traspasaba a la autora, pues es esta la semilla de la escisión, la huella que permite alumbrar tímidamente la génesis del posterior devenir de lo diverso. Sin embargo, ¿es verdaderamente posible discernir entre esta y la diversidad psíquica? ¿Y entre esta, la diversidad psíquica como patología y aquella que ya ha devenido identidad en el sujeto? Y es que la génesis a la que nos referimos podría para algunos entenderse ya como un desequilibrio psicológico - una fragilidad y sensibilidad extremas- en sí misma. Para considerarlo nos disponemos a dar cuenta de los aspectos que abarca.

Un largo camino fue el que condujo a Elías Pizarnik y a Rezla Bromiker de Pizarnik a Avellaneda desde su Rovne natal en 1934. La joven pareja rusa que en la década de los cuarenta disfrutaba ya de una estabilidad económica y una posición dentro de la comunidad centroeuropea, no dudó en inculcarles a sus hijas, Myriam y Flora Alejandra -nacidas en territorio argentino- el amor por la cultura judía para lo que complementaron la educación de la escuela pública con la asistencia al Zalman Reizien Schule, donde aprendieron a leer y a escribir en iddish, estudiaron la historia del pueblo judío y su religión. Apunta Alicia Borinsky que efectivamente "la sensibilidad de Pizarnik es judía por su pasión nomádica" (Borinsky 2000: 411). Cabe preguntarse entonces si el sentimiento de extranjería tiene relación directa con esta pertenencia, el posible cuestionamiento de las creencias heredadas o la resonancia de la extrema violencia ejercida implacablemente por el nazismo en su voluntad por exterminar al pueblo judío que inevitablemente golpearía el ánimo familiar. Sus versos reposan desde el inicio de su trayectoria poética, no en vano su primera colección de poemas se titula La tierra más ajena, en ese reconocerse extranjera. En "Cenizas", composición que podemos encontrar en su segundo poemario, La última inocencia, leemos:

La noche se astilló en estrellas

mirándome alucinada

el aire arroja odio [...]

Arcano sueño

antepasado de mi sonrisa

el mundo está demacrado

y hay candado pero no llaves

y hay pavor pero no lágrimas.

¿Qué haré conmigo?

Porque a Ti te debo lo que soy

Pero no tengo mañana

Porque a ti Te...

La noche sufre. (Pizarnik 2007: 55) 
Esta plegaria desesperada que no obtiene respuesta de un Dios judío, ya ausente, adquiere dimensiones cósmicas en el poema gracias a la personificación de la noche del mundo a la que se asimila dolorosamente la poeta cuya voz temblorosa se ve desbordada por el dolor de la herida presentida del ser para la muerte, pálpito que aparece igualmente materializado en su diario, en la entrada del 28 de septiembre de 1954: "De pronto, siento náuseas de mi resignación de ser-parala-muerte. ¡No! ¡Quiero liberarme! ¡Quiero vivir!” (Pizarnik 2016: 30) o el 5 de agosto de 1955: "Al escribir esto, levanto los ojos. En el jardín, las hojas mueren. El cielo es pálido. Me doy cuenta de que estoy llorando. Es difícil. Es difícil morir bien" (Pizarnik 2016: 125).

Cristina Piña, autora del volumen Poesía y experiencia: Leer a Alejandra Pizarnik, es rotunda al afirmar que tanto el origen judío de la familia como la vivencia de la condición de desplazados de sus padres son episodios fundamentales que contribuyeron a la forja de esta extranjería; así como, la ya mencionada divergencia religiosa a cuyo desfiladero nos asoma "Cenizas" - que condujo a la joven Alejandra a reconocerse en los durísimos versos del Vallejo de Los heraldos negros y que resuenan en el grito ensordecedor y en la experiencia límite del lenguaje en Trilce: "Hay golpes en la vida, tan fuertes...Yo no sé./ Golpes como del odio de Dios" (Vallejo 2019:11), revelación ratificada en su diario de junio de 1955 (Pizarnik 2016: 39-40).

Algo que llama poderosamente la atención si tenemos en cuenta que Pizarnik no bebe de la literatura argentina, hispanoamericana o española: "Es extraño: en español no existe nadie que me pueda servir de modelo. El mismo Octavio [Paz] es demasiado inflexible, demasiado acerado o simplemente viril. En cuanto a Julio [Cortázar] no comparto su desenfado en sus escritos en que emplea el lenguaje oral. Borges me gusta, pero no deseo ser uno de tantos epígonos de él" (Pizarnik 1984: 277).

Su interés se centra en los poetas alemanes y franceses mencionados y en general, en la literatura francesa: Paul Éluard y André Breton -que tradujo junto con Juan-Jacobo Barjalía - André Gide, Marcel Proust, Jean-Paul Sartre o Simone de Beauvoir, entre otros. De hecho, la propuesta pizarnikiana tampoco puede asimilarse a las corrientes poéticas de la década de los cuarenta en Argentina en cuyas filas destacaron Olga Orozco, Enrique Molina y Alberto Girri, tal y como señala Patricia Venti en su trabajo "Alejandra Pizarnik en el contexto argentino" y de las que la poeta argentina habría bebido. A saber: la neorromántica, la línea surrealista encabezada por Aldo Pelligrini y la nacionalista que integraba dos variantes: los poetas del noroeste argentino y los del ámbito bonaerense; ni a las de los cincuenta: el realismo-romántico y la vanguardia (Venti 2007-2008). Y así, 
la patria íntima escogida por la escritora no fue tampoco argentina sino la capital francesa en la que Alejandra Pizarnik viviría por deseo propio cuatro años.

Sin embargo, la relación con la familia tampoco fue fácil para Alejandra, lo que se convertiría en acicate para reafirmar el sentimiento de soledad y acentuaría el de extranjería. Alejandra era permanentemente comparada con su hermana Myriam con cuyas aspiraciones y cuyos sueños coincidían con el cumplimiento de las expectativas patriarcales y con la imagen del ángel del hogar, en la que esta nunca se reconoció. Apunta Luce Irigaray en su ensayo Amo a ti. Bosquejo de una felicidad en la historia que

La hija no tiene otro motivo de ser que el de convertirse en esposa y madre. Por esta razón, su madre representa para ella esta función abstracta, y ella para su madre. Son dos funcionarias de lo universal, de un universal inapropiado a su naturaleza singular, desde ese momento ajenas la una a la otra. [...] El duelo más radical de la singularidad humana pasa por este borramiento en lo universal, $\mathrm{u}$ holocausto del espíritu, de esta relación entre madre e hija. (Irigaray 1994: 46)

Conviene puntualizar que Irigaray integra esta aserción en un marco mayor articulado con el propósito de reflexionar sobre la felicidad y la mujer y en él insiste en que "el amor de la mujer es definido como deber familiar y civil" por lo que

Ella no tiene derecho al amor singular ni al amor por ella misma. Por tanto, no puede amar, sino estar sometida al amor y a la reproducción. Debe ser sacrificada y sacrificarse en esta tarea, desaparecer en ella como o cual mujer actualmente viviente. Debe desaparecer en ella también como deseo, cuando no abstracto: deseo de ser esposa y madre. Este borramiento de ella misma en una función ligada a la familia en su tarea civil. (Irigaray 1994: 39)

Tanto la vida como la obra de Pizarnik aspiran a desbaratar esta lógica del discurso patriarcal por lo que podemos integrar este sentimiento de exclusión que conlleva a acrecentar la soledad, pero también la voluntad disidente en su extranjería ${ }^{13}$. Sharon Keefe Ugalde y Noni Benegas han insistido que la escritura femenina ha estado históricamente signada por un profundo sentimiento de abandono derivado del lugar que ha ocupado mujer en la sociedad patriarcal (Benegas/Keefe Ugalde 2000: 140). Por su parte, Pilar Cuder prefiere hablar de

13 María José Bruña Bragado en su trabajo "Pizarnik-artefacto: autoconfiguración y mito" realiza esta interesante apreciación: "su dispersión en múltiples voces, figuraciones e identidades - extranjera, nómada, bohemia, judía, lesbiana, mujer- es una estrategia sutilmente consciente de inscripción liminar, excéntrica en el canon o espacio paratópico mencionado y en ningún momento una imposición de fuera o una manipulación ajena" (Bruña Bragado 2012: 61). 
exilio femenino (Cuder 2000: 11-12). Sea como fuere, cierto es que la palabra poética de Alejandra Pizarnik está traspasada por la marca de lo ausente: "No es un verbo sino un vértigo. No indica acción. No quiere decir ir al encuentro de alguien sino yacer porque alguien no viene" (Pizarnik 2007: 344).

El lenguaje poético en este contexto no solo registra la indudable naturaleza marginal del yo pizarnikiano, sino que se vuelve a menudo espejo en el que la poeta da cuenta del desdoblamiento, dinámica central de la diversidad psíquica, que es también plano en el que se revela la insuficiencia del lenguaje como ámbito único en el que ser y estar:

alejandra alejandra

debajo estoy yo

alejandra.

Interpela entonces al silencio para que calme su dolor y su agitación y la provea de un ámbito en el que guarecerse:

silencio

yo me uno al silencio

y me dejo caer

me dejo hacer

me dejo beber

me dejo decir (pág. 143)

Tal y como apunta Núria Calafell este silencio "no sólo se inscribe en el tejido del texto, siendo hilo y aguja a un mismo tiempo, sino que se convierte en un elemento de autorreflexión literaria, en el trazo de una huella que agujerea la letra y se coloca en el lugar otro desconocido y anhelado" (Calafell 2007: 95).

Sin embargo, la angustia prevalece, también una dolorosa desesperación y la única forma de reconocerse es en la de dejar supurar la herida, única morada posible:

En la mano crispada de un muerto,

en la memoria de un loco,

en la tristeza de un niño

en la mano que busca el vaso,

en el vaso inalcanzable

en la sed de siempre

Pero también en la de asumirse quebrada y rota, fragmentada hasta el extremo, relato al que asistimos en "El infierno musical" que encontramos en el poemario de idéntico título: 
Golpean con soles

Nada se acopla con nada aquí

Y de tanto animal muerto en el cementerio de huesos filosos de mi memoria

$\mathrm{Y}$ de tantas monjas como cuervos que se precipitan a hurgar entre mis piernas

La cantidad de fragmentos me desgarra (Pizarnik 2007: 268)

La extranjería, el desdoblamiento, la fragmentación, el lenguaje, el desgaste de la palabra y el silencio conducen a Alejandra Pizarnik a invocar a la muerte como única solución posible en sus versos. Ya no hay vuelta atrás y el ritual de su convocatoria crece dentro de la poeta y fuera en el cuerpo del poema, convertidos en un solo discurso tras el pacto: "Vida, mi vida, déjate caer, déjate doler, mi vida, déjate enlazar de fuego, de silencio ingenuo, de piedras verdes en la casa de la noche, déjate caer y doler, mi vida" (Árbol de Diana, Pizarnik 2007: 137). El dolor, dinámica transversal de su imaginario poético íntimamente vinculada con el impacto de la vivencia de la diversidad funcional ora arma, ora herida, ante su resistencia a ser transitado (Scarry 1985: 5) ${ }^{14}$ precipita el final y la caída.

En el poema "Caminos del espejo", la poeta relata el ingreso en la muerte. Y así, este deviene en el umbral en el que ella reposa como una ofrenda como "ramo que abandona el viento"; "como un animal herido en el lugar que iba a ser de revelaciones"; ella ingresa en la oscuridad de lo elemental y como Ofelia avanza río abajo, con voz y sin vida deslumbrada por el viento y los pájaros:

\section{$\mathrm{XV}$}

Delicia de perderse en la imagen presentida. Yo me levanté de mi cadáver, yo fui en busca de quien soy. Peregrina de mí, he ido hacia la que duerme en un país al viento.

14 En su trabajo titulado The Body in Pain. The Making and Unmaking of the World, Elaine Scarry habla del dolor físico y apunta: "whatever pain achieves, it achieves in part through its unsharability through its resistance to language" para insistir después en el gran valor que tiene la literatura y particularmente, la poesía que transita su representación. Una exploración, por otro lado, que según Scarry es "a necessary prelude to the collective task of dimishing pain" (Scarry 1985: 4-5). Si cierto es que la académica centra su estudio en la representación del dolor físico, consideramos que a partir de la definición de cuerpo propuesta por Corbain y a la que nos hemos adscrito (ver la nota a pie página número 6), la obra literaria de Alejandra Pizarnik, y muy especialmente su producción poética, se erigen como una valiosa representación de la diversidad funcional y más concretamente, de la diversidad psicológica que pone de manifiesto una vivencia del dolor físico y psicológico indiscerniblemente, esto es, como un continuo que Pizarnik transmuta en una fecunda búsqueda que generosamente comparte con el mundo contribuyendo a su visibilidad. 


\section{XVI}

Mi caída sin fin en donde nadie me aguardó pues al mirar quién me aguardaba no vi otra cosa que mí misma.

XVII

Algo que caía en el silencio. Mi última palabra que yo pero me refería al alba luminosa.

XVIII

Flores amarillas constelan un círculo de tierra azul. El agua tiembla llena de viento.

XIX

Deslumbramiento del día, pájaros amarillos en la mañana. [...]

(Pizarnik 2007: 243-244)

\section{Bibliografía}

Antebi, Susan/Jörgensen, Beth E. 2016. "Introduction. A Latin American Context for Disability Studies", en: Susan Antebi/Beth Jörgensen (eds.), Libre Acceso. Latin American Literature and Film through Disability Studies, Albany: State University of New York Press: 1-26.

Bachelard, Gaston. 2003. El aire y los sueños, Ciudad de México: Fondo de Cultura Económica.

Benegas, Noni/Keefe Ugalde, Sharon. 2000. "Poesía y mujer: una identidad múltiple", en: Jordi Gracia (ed.), Historia y crítica de la literatura española. Los nuevos nombres: 1975-2000. Primer suplemento, vol. 9, tomo 2, Barcelona: Crítica, DL: 137-141.

Borinsky, Alicia. 2000. "Memoria del vacío. Una nota personal en torno a la escritura y a las raíces judías", en: Revista Iberoamericana 191: 409-412, https://revista-iberoamericana.pitt.edu/ojs/index.php/Iberoamericana/ article/view/5778/0 [20-01-2019].

Bruña Bragado, María José. 2012. "Pizarnik-artefacto: autoconfiguración y mito", en: Revista Letras 8: 55-70, http://revistaseug.ugr.es/index.php/letral/article/ view/3683 [20-01-2019].

Calafell Sala, Núria. 2007. "A la búsqueda de la soledad sonora. Formas del silencio en la poética de Alejandra Pizarnik", en: Lectora 13: 85-100, http:// revistes.ub.edu/index.php/lectora/article/view/7402/0 [21-01-2019].

Calinescu, Matei. 1991. Cinco caras de la modernidad. Modernismo, vanguardia, decadencia, kitsch, posmodernismo, Madrid: Tecnos.

Cervera Salinas, Vicente. 2010. "Las cenizas del reino. El hermoso delirio de Alejandra Pizarnik", en: Cartaphilus. Revista de investigación y crítica estética 
7-10: 112-122, https://revistas.um.es/cartaphilus/article/view/112781 [2101-2019].

Corbain, Alain. 2005. "Introducción", en: Alain Corbain/Jean-Jacques Courtine/Georges Vigarello (eds.), Historia del cuerpo (II). De la Revolución Francesa a la Gran Guerra, Madrid: Taurus: 15-17.

Cúder Domínguez, Pilar. 2000. Exilios femeninos, Huelva: Universidad de Huelva.

Fraser, Benjamin. 2013. Disability Studies and Spanish Culture. Films, Novels, the Comic and the Public Exhibition, Liverpool University Press.

Goldstein, Kevin. 2016. "La cara que me mira. Demythologizing Blindness in Borges's Disability Life Writing”, en: Susan Antebi/Beth Jörgensen (eds.), Libre Acceso. Latin American Literature and Film through Disability Studies, Albany: State University of New York Press: 47-61.

Hartwig, Susanne. 2018. "Introducción: representar la diversidad funcional", en: Julio Checa/Susanne Hartwig (eds.), ¿Discapacidad? Literatura, teatro y cine hispánicos vistos desde los disability studies, Berlin: Peter Lang: 7-21.

Irigaray, Luce. 1994. Amo a ti, Barcelona: Icaria.

Jörgensen, Beth F. 2016. "Negotiating the Geographies of Exclusion and Access. Life Writing by Gabriela Brimmer and Ekiwah Adler-Beléndez", en: Susan Antebi/Beth Jörgensen (ed.), Libre Acceso. Latin American Literature and Film through Disability Studies, Albany: State University of New York Press: 63-79. Juárez-Almendros, Encarnación. 2013. "Disability Studies in the Hispanic World: Proposals and Methodologies", en: Arizona Journal of Hispanic Cultural Studies 17: 9.

Kavčič, Nada. 2017. "Itinerario poético del cuerpo en vértigo: el personaje de Alejandra Pizarnik y el valor ontologizador de la despersonalización del yo poético", en: Verba hispánica: anuario del Departamento de Lengua y Literatura Españolas de la Facultad de Filosofía y Letras en la Universidad de Ljubljana 25: 217-230.

Marr, Matthew J. 2013. The Politics of Age and Disability in Contemporary Spanish Film. Plus Ultra Pluralism, New York/London: Routledge.

Martín, Sarah. 2007. "El abismo del silencio, la pulsión de muerte. Una propuesta de lectura de Los trabajos y las noches de Alejandra Pizarnik", en: Lectora 13: 69-84, http://revistes.ub.edu/index.php/lectora/article/view/7401 [21-0119].

Negroni, María. 2003. El testigo lúcido. La obra de sombra de Alejandra Pizarnik, Rosario: Beatriz Viterbo Editora.

Olivio Jiménez, José. 1994. "Introducción a la poesía modernista hispanoamericana”, en: José Olivio Jiménez (ed.), Antología crítica de la poesía modernista hispanoamericana, Madrid: Hiperión: 9-56. 
Paz, Octavio. 1986. Los hijos del limo. Del romanticismo a la vanguardia, Barcelona: Seix Barral.

Piña, Cristina. 1999. Poesía y experiencia del límite: Leer a Alejandra Pizarnik, Buenos Aires: Botella al Mar.

Piña, Cristina. 2005. Alejandra Pizarnik. Una biografía, Buenos Aires: Corregidor.

Piña, Cristina (ed.). 2015. En la trastienda del lenguaje: Nueve miradas de la escritura de Alejandra Pizarnik, Pittsburg: Instituto Internacional de Literatura Iberoamericana.

Pizarnik, Alejandra. 1984. Semblanza, México: Fondo de Cultura Económica.

Pizarnik, Alejandra. 2007. Poesía completa, 2a ed., Barcelona: Lumen.

Pizarnik, Alejandra. 2016. Diarios, $3^{\text {a }}$ ed., Barcelona: Lumen.

Romañach, Javier/Lobato, Manuel. 2005. "Functional diversity, a new term in the struggle for dignity in the diversity of the human being", en: Independent Living Forum (Spain), https://disability-studies.leeds.ac.uk/wp-content/uploads/sites/ 40/library/zavier-Functional-Diversity-Romanach.pdf [15-01-2019].

Scarry, Elaine. 1985. The Body in Pain. The Making and Unmaking of the World, New York/Oxford: Oxford University Press.

Spivak, Gayatri Chakravorty. 1988. In Other Worlds. Essay in Cultural Politics, New York/London: Routledge.

Vallejo, César. 2019. Los heraldos negros, Barcelona: Red ediciones.

Venti, Patricia. 2007-2008. "Alejandra Pizarnik en el contexto argentino", en: Espéculo. Revista de estudios literarios 37, https://webs.ucm.es/info/ especulo/numero37/pizaconte.html [25-01-2019].

Venti, Patricia. 2008. La escritura invisible en Alejandra Pizarnik, Madrid: Anthropos.

Venti, Patricia. 2008a. Bibliografía completa de Alejandra Pizarnik, Madrid: Del Centro.

VV.AA. 2013. "Disability Studies in the Hispanic World", en: Arizona Journal of Hispanic Cultural Studies 17.

Zambrano, María. 1997. Filosofía y poesía, Madrid: Ediciones del Orto. 
Berit Callsen

Universität Osnabrück

\title{
Cuerpo y mente extraordinarios: formas de inclusión y concepción de figuras en la obra cuentística de Guadalupe Nettel
}

\begin{abstract}
This chapter analyses a sample of short stories that were published between 2008 and 2013 by the Mexican author Guadalupe Nettel and that have been hardly investigated until now. Adopting a comparative perspective, the chapter seeks to identify the textual strategies Nettel applies in her writing of the extraordinary body. Hence, it focuses especially on different semantics of inclusion that the primary texts create in processes of projection, participation and positioning. It will turn out that the protagonists in their tendencies of self-reflection and re-appropriation of the self are in the center of negotiations of differences making visible the constructional character of selfhood and corporeal deviations.
\end{abstract}

Keywords: negotiation, (self-)belonging, sight, space, mutational body

\section{Introducción}

Tanto en su obra novelística como en sus cuentos que reúne en los libros Pétalos y otras historias incómodas (2008) y El matrimonio de los peces rojos (2013), la escritora mexicana Guadalupe Nettel se fija en lo físicamente extraordinario. ${ }^{1}$ Sus figuras destacan no solamente por poseer o percibir cuerpos que pueden irritar la vista, sino que demuestran en muchos casos un nivel reflexivo y autorreflexivo sumamente alto. ${ }^{2}$ Así, meditan sobre nociones de la diferencia y sobre el estatus de solitarios y 'outsiders'. En ello, se intuye muchas veces la elaboración de una dialéctica entre lo extraordinario y lo común, entre exclusión e inclusión.

En un análisis comparativo de los cuentos "Ptosis", "Bonsái", "Felina" y "Hongos”, recogidos en los volúmenes mencionados, esta contribución tratará de detectar el funcionamiento poético de una tal escritura de lo extraordinario en la obra de Nettel. Los cuentos, así la tesis, desarrollan a través de sus figuras reflexiones en torno a una apariencia de lo incomún que permiten observar el

1 Entre sus novelas destacan El huésped (2006) y El cuerpo en que nací (2011) con respecto a la temática aquí enfocada.

2 El alto nivel de autorreflexión se puede considerar una característica recurrente en la narrativa de Nettel. Véase acerca de esta temática Callsen 2018: 223-224. 
mismo proceso de (auto)construcción de lo extraordinario. Desde el punto de vista metodológico, este estudio persigue un proyecto de close reading que, si bien tiene en mente ciertas posiciones teóricas de los así llamados disability studies y recurre al concepto interdisciplinar de la inclusión, se centra primordialmente en las realidades corporales que construyen y representan los cuentos en cuestión con motivo de identificar el saber literario que contienen y proclaman en torno al cuerpo extraordinario. ${ }^{3}$

Aún así conviene echar un breve vistazo al concepto de la inclusión que figura al centro de estas realidades corporales ficticias. En estudios provenientes de las ciencias sociales se destaca a menudo el concepto de la pertenencia en procesos de inclusión (véanse p. ej. Wolters 2014: 14 y Kammeyer/Baumert 2015: 12) -concepto que las Naciones Unidas en la Convención Internacional sobre los Derechos de las Personas con Discapacidad denominan "sense of belonging", referiéndose al derecho a pertenecer (véase Wolters 2014: 14). Asimismo, desde estas perspectivas, la inclusión se basa en contactos interpersonales en y desde la diferencia. Partiendo de estas ideas básicas aquí quisiéramos atenernos a una definición tentativa del término "inclusión" cuyas nociones se interrelacionan y se complementan mutuamente: entendemos la inclusión como proyecto ético-social de la pertenencia en cuyo marco se desarrollan procesos de construcción identitaria. En este sentido, la inclusión se abarca como concepto multidimensional, dándose en un nivel tanto inter como intrapersonal en función de relaciones de solidaridad y procesos de autorreflexión. En total, tratamos el concepto de inclusión como figura de pensar que puede meditar sobre formas de pertenencia y de autopertenencia y que lleva a cabo negociaciones de diferencias. Aquí se prefiguran aspectos que se pueden considerar móviles de una escritura de lo extraordinario, tal como la concibe Nettel.

3 Las posiciones teóricas con las que se comunica este estudio emergen, por un lado, del así llamado modelo cultural de la discapacidad que desarrolló Anne Waldschmidt. (véanse Waldschmidt 2005 y 2007) Por el otro, se relacionan con la noción continua que Julie Nack propone de la discapacidad en tanto "shifting health state" (2012: 5) y con la ida de una "operation of disability" que propone Rosemarie Garland Thomson (1997: 9). Todos estos enfoques convergen en la tendencia de subrayar el aspecto constructivista de la discapacidad subsumiéndola, así, bajo un término de "diversidad funcional". Para una discusión más exhaustiva de estos conceptos y una introducción de los disability studies en el campo científico europeo véase p. ej. Dederich 2007. En cuanto a una perspectiva de las ciencias literarias y culturales hacia los disability studies que proviene del campo hispanístico-alemán véanse p. ej. Checa/Hartwig 2018. 
Como se verá, en sus reflexiones sobre la apariencia de lo incomún, los cuentos estudiados a continuación abordan la temática de la inclusión desde enfoques distintos y, al mismo tiempo, complementarios: "Ptosis" medita sobre la oposición interrelacionada de lo común y lo extraordinario y en ello se centra en el rol de la mirada constructiva. "Bonsái" escenifica procesos de exclusión y distanciamiento tanto físicos como mentales y crea, así, un espacio aparentemente apartado de crecimiento individual. Y "Felina" y "Hongos" ponen el enfoque en la experiencia inmediata de la mutación corporal que se aplica en la búsqueda de la reapropiación individual. Se abrirán, en ello, continuos e inversiones de las nociones de lo común y lo extraordinario que permiten sondear semánticas de la inclusión en los textos en cuestión.

\section{2 "Ptosis": formas de inclusión desde la mirada proyectiva}

El cuento "Ptosis" se narra en primera persona, desde la perspectiva de un fotógrafo oftalmológico que trabaja en un hospital en París donde se ejerce sobre todo la cirugía de párpados. En el ámbito medicinal, "Ptosis" denomina la alienación defectuosa del párpado superior de uno o de los dos ojos, debido -muchas veces- a un defecto de músculos o nervios en el ojo afectado. La tarea del protagonista sin nombre consiste en tomarles fotografías a los pacientes antes y después de la operación que es prevista de mejorar el supuesto defecto físico. En el primer tercio del cuento prevalece un tono neutral y hasta frío en la voz del fotógrafo. Así, informa de manera objetiva y casi analítica sobre las diferentes razones de la intervención quirúrgica:

A pesar de lo que pueda pensarse, las cirugías de los párpados son muy frecuentes y sus razones innumerables, comenzando por los estragos de la edad, la vanidad de la gente que no soporta las marcas de vejez en el rostro; pero también los accidentes de coche, que a menudo desfiguran a los pasajeros, las explosiones, los incendios y otra serie de imprevistos: la piel de un párpado es de una delicadeza insospechada. (Nettel 2008: 14)

A pesar del distanciamiento que subyace en el tono analítico, aquí, ya se revela cierta fascinación por esta parte del cuerpo a la cual se suele aportar poca importancia. Y es a partir de esta fascinación sutil que el protagonista comienza a desarrollar tendencias obsesivas hasta con los párpados en su alrededor cotidiano:

Cuando paseo, generalmente lo hago sin la cámara, ya sea porque se me olvida o por miedo a perderla. Confieso sin embargo que a menudo, mientras camino por la calle o los pasillos de algún edificio, siento deseos repentinos de tomar una foto, no de paisajes o puentes [...] sino de párpados insólitos que de cuando en cuando detecto entre la multitud. (ibíd.: 15) 
Aprendemos que aquí se conforma una percepción guiada y selectiva que organiza no solamente los objetos percibidos sino también el espacio en que estos aparecen.

Además, al parecer, la necesidad profesional en lo privado se convierte en deseo y ansia emocional. Así, el fotógrafo emprende la búsqueda voluntaria de lo extraño y extraordinario y es durante esta búsqueda misma que lleva a cabo procesos de idealización y proyección. En su perspectiva, el párpado, y más específicamente el párpado defectuoso, se convierte en un fetiche cuya fijación con la cámara requiere una habilidad especial:

Esta parte del cuerpo $[\ldots]$ me resulta fascinante. Exhibida y oculta de manera intermitente, obliga a permanecer alerta para descubrir algo que de verdad valga la pena. El fotógrafo debe evitar parpadear al mismo tiempo que el sujeto de estudio y capturar el momento en que el ojo se cierra como una ostra juguetona. He llegado a creer que para eso se necesita una intuición especial, como la de un cazador de insectos, no creo que haya mucha diferencia entre un aleteo y un batir de pestañas. (ibíd.: 15-16)

En el proyecto de capturar y fijar lo extraordinario, la profesión se insinúa como vocación y desafío. En ello, lo deformado e incomún de la apariencia de los pacientes se produce como un hallazgo. En este sentido, no puede sorprender que frente a las operaciones que se llevan a cabo en la clínica, previstas a hacer desaparecer el presunto defecto, el protagonista adopta una actitud reservada, si no la podemos calificar de crítica:

Esa mejoría pocas veces alcanza el cien por ciento pero cambia por completo un rostro, su expresión, su gesto permanente. En apariencia los ojos quedan más equilibrados, sin embargo, cuando uno mira bien $-\mathrm{y}$ sobre todo cuando ha visto ya miles de rostros modificados por la misma mano-, descubre algo abominable: de algún modo, todos ellos se parecen. Es como si el doctor Ruellan imprimiera una marca distintiva en sus pacientes, un sello tenue pero inconfundible. (ibíd.: 17)

Es evidente que a partir de la mirada del fotógrafo, son las operaciones de belleza las que igualizan cualquier detalle individual formando toda una "tribu de mutantes" (ibíd.: 20) como revela paradójicamente en otro momento. Aquí las categorías de lo normal y lo incomún comienzan a difuminarse. ${ }^{4}$

4 A partir de la disolución de las categorías mencionadas el texto propone, no por último, una crítica a los procedimientos del así llamado "human enhancement" y de las operaciones de belleza que llevan a cabo intervenciones biotécnicas a fin de "mejorar" las condiciones y apariencias del cuerpo humano no necesariamente deformado o enfermo (véase Stammberger 2012: 194). De esta manera, parece subyacer en el cuento un segundo nivel semántico que adquiere un carácter apelativo: se organiza en torno a la naturaleza corporal como proyecto ético. 
La crítica hacia las prácticas de la operación finalmente adquiere un alcance privado y un carácter emocional cuando el protagonista se enamora de una de las pacientes en la clínica, es decir de su belleza extraordinaria. Confiesa: "Hubiera dado cualquier cosa por seguir mirando durante la tarde entera ese párpado pesado y al mismo tiempo frágil y habría dado el doble por que esos ojos se fijaran en mí" (ibíd.: 19). Por consiguiente, quiere convencer a la mujer, con la cual comienza una relación amorosa, de no operarse, cosa para la cual al final le faltan fuerza y coraje. Así, termina sintiéndose "[...] como si de alguna forma su escapelo [del doctor Ruellan] también me hubiera mutilado" (ibíd.: 24).

Lo que está en juego en este cuento parece ser tanto una fijación como una dinamización de la mirada. La dinamización se da en el sentido de la capacidad de ver más allá de lo común y corriente y de llegar a repensar, a través de esta mirada dinamizada, los términos de lo normal y lo deforme. Al mismo tiempo, es evidente que el fotógrafo lleva a cabo procesos de construcción y proyección: en su mirada fascinada el cuerpo deforme se erige como objeto de una belleza extraordinaria y al final el cuerpo entero del enamorado se identifica con el ojo de la amada, de manera que se siente igualmente mutilado. Esta mirada tanto deformadora como renovadora, si la queremos llamar así, se multiplica a través de la cámara fotográfica y las proyecciones idealizantes se congelan de esta manera. Por consiguiente, es solo una perspectiva, la del cuerpo masculino, aparentemente no deformado o mutilado, la que se transporta en el texto. Ello revela un desencuentro de miradas y un doble punto ciego. Este doble punto ciego consiste en la de-presentación de la percepción corporal de la paciente, así como en su perspectiva no existente hacia el otro. Es sobre todo a partir de esta doble omisión visual que la mirada del protagonista puede llenar el espacio y concebir una apariencia propia de lo incomún. Y es a partir de este doble punto ciego que la cita de Mario Bellatin que Nettel antepone a su colección de cuentos cobra su fuerza significativa: “¿En qué consiste la belleza del monstruo?” pregunta Bellatin y deja abierto el origen de esta belleza ambivalente al autorresponder: "En su no darse cuenta”. ¿Qué le hace bello al monstruo, entonces, el no darse cuenta de su monstruosidad o la ignorancia de su belleza? Aquí se abre un ambiguo espacio paratextual de proyección e imaginación que puede funcionar como mise en abyme de la dinámica proyectiva que se desarrolla a lo largo del cuento. Es justamente la construcción visual y mental extrema, la percepción tanto proyectiva como reduccionista, que llega a poner en entredicho las categorías de lo común y lo incomún, de lo bello y lo deforme en este cuento y que ayuda a conformar un sucesivo posicionamiento exclusivo del protagonista. Así, su mirada única marca una toma de posición que desde un afuera se aplica al otro queriendo acercarse y hasta adentrarse en él. 
Por lo tanto, en "Ptosis" el juego entre fijación y dinamización de la mirada (masculina) deviene la base de procesos de construcción de lo extraordinario. En estas construcciones se lleva a cabo la negociación y apropiación de diferencias aparentes y de desviaciones percibidas en la medida en que estas se idealizan. El motivo de la pertenencia como núcleo de la idea de la inclusión se moviliza a través de esta apropiación de diferencias y desviaciones que, en ello, devienen objetos de la proyección del protagonista. En este sentido, cabe subrayar que el móvil de la inclusión emerge aquí de la perspectiva del narrador - otra inversión que lleva a cabo el cuento. Lo extraordinario es lo que se quiere, se anhela y lo que, por ello, ha de conservarse. Y es lo deforme lo que el protagonista, al final, cree experimentar para sí mismo. Imaginándose como parte del cuerpo defectuoso y premutilado la figura principal crea una idea de pertenencia que radica, fundamentalmente, en la identificación idealizada con el otro. Aquí se evidencia también un proceso de proyección y posicionamiento que abarca ambos polos del continuo inclusivo-exclusivo.

\section{3 "Bonsái": formas de inclusión desde el espacio aislado}

El cuento "Bonsái" se evoca como fábula inclusiva. A lo largo de la narración en primera persona se conforma una paralelización e interacción del mundo botánico y mundo humano que lleva a cabo una meditación aparentemente paradójica sobre procesos de inclusión: nociones de pertenencia se abordan aquí desde su otro lado - a partir de la soledad, el aislamiento y la exclusión-. "Bonsái" narra la historia del señor Okada quien en el matrimonio con su esposa Midori experimenta cierta lejanía después de varios años de ser casados. El protagonista tiene la costumbre de ir a pasear los domingos en el jardín botánico de Aoyama, reconociendo este espacio como suyo, apto para alejarse de la vida laboral y la rutina del matrimonio. A pesar de que ya persigue esta costumbre desde hace varios años, nunca entró al invernadero que se encuentra en el jardín hasta que un día (y sin mayor razón visible) comienza a interesarse por este edificio. La primera impresión del interior ya se presenta como contraste del mundo exterior: "Miré a mi alrededor. En el invernadero todas las plantas se veían perfectamente aliñadas y brillantes. Todo parecía estar en su sitio: las plantas de luz en los lugares soleados. Las de sombra en el fondo del galpón, más oscuro que la parte de enfrente" (ibíd.: 44). Al parecer, aquí se erige un sistema espacial aparte con un orden propio que sabe poner 'todo en su lugar'.

El narrador se va adentrando a este microcosmos que parece evocar un contramundo en tanto espacio de refugio que se opone al mundo exterior en el cual se siente cada vez más perdido. Aun así, el invernadero debe considerarse 
un espacio semánticamente paradójico que protege, aísla y excluye al mismo tiempo y que ayuda a crecer bajo condiciones artificiales. Así, ya se puede intuir el alcance simbólico de este edificio que funge como núcleo del cuento. Es más, a lo largo del texto el invernadero se vuelve un laboratorio experimental de cuerpo y mente humanos, así como de relaciones interpersonales y hasta interorgánicas.

Así, el señor Okada, poco a poco comienza a entablar amistad con el jardinero que se ocupa del invernadero y que a lo largo del cuento obtiene un rol de instructor. Afirma el jardinero sabiamente y anticipando ciertos desarrollos del protagonista: "Las plantas son seres vivos, señor Okada y la relación que uno mantiene con ellas es como cualquier relación con un ser vivo" (ibíd.: 43). A partir de este momento, el protagonista comienza a desarrollar una mirada diferente hacia las plantas: "[...] de pronto les fui descubriendo cierta personalidad. En pocas palabras, dejaron de ser objetos para convertirse en seres vivos" (ibíd.: 46-47). Y es una planta en especial por la cual comienza a interesarse:

Un día, por ejemplo, noté que el jardinero no se ocupaba nunca de los cactus. Estaban ahí, olvidados en su tierra seca y cobriza. Algunos erguidos como centinelas, otros en forma de ovillo, a ras del suelo, asumiendo la posición circunspecta de un erizo. Me acerqué a su maceta y me quedé observándolos durante algunos minutos. No parecía haber en ellos ningún movimiento, además de esa actitud tiesa y como a la defensiva. La multitud de espinas diminutas sobre esa piel verdosa me hizo recordar mi propio rostro cuando llevo más de dos días sin afeitarme. Pero más allá de la barba, me pareció que los cactus y yo teníamos algo en común [...]. (ibíd.: 47)

En el acercamiento a los cactus el protagonista experimenta un proceso continuo de comprehensión, empatía y hasta de identificación interorgánica de la cual la apariencia física solo marca el punto de partida. Aprendemos que la cercanía y familiaridad que siente hacia esta planta emergen, asimismo, de su aparente otredad:

Qué diferentes eran de las otras plantas, como los expansivos helechos o las palmeras. Entre más los miraba, más comprendía a los cactus. Seguramente se sentían solos en ese gran invernadero, sin la posibilidad de comunicarse siquiera entre ellos. Los cactus eran los outsiders del invernadero, outsiders que no compartían entre ellos sino el hecho de serlo y, por lo tanto, de estar a la defensiva. 'Si yo hubiera nacido planta', reconocí para mis adentros, 'no habría podido sino pertenecer a ese género'. (ibíd.)

Aquí la autoidentificación con los cactus coincide con el autorreconocimiento del estatus del ser excluido. Presenciamos, de esta manera, un proceso de toma de conciencia, de sucesiva autocoherencia y crecimiento individual originado y catalizado por el espacio apartado y exclusivo del invernadero, así como por la presencia olvidada de los cactus. Por consiguiente, señor Okada desarrolla una 
perspectiva variada no solamente sobre su propia apariencia e identidad sino también sobre sus costumbres de actuar y relacionarse con su alrededor social:

Fue como una liberación. En ese momento dejé de preocuparme por cosas que antes me pesaban y me causaban angustia, como el hecho de no saber bailar. [...] También por esas fechas dejé de propinar sonrisas hipócritas a los colegas que encontraba en el restaurante de la empresa, como había hecho durante tantos años. No era falta de amabilidad, sino simple coherencia con mi naturaleza. Y, al contrario de lo que se podía esperar, la gente no lo tomó a mal. Es más, los compañeros de oficina comentaban que últimamente me veía 'en buena forma', incluso 'más natural'. (ibíd.: 49)

A partir de esta identificación tanto corporal como mental con los cactus, el cuento escenifica procesos de autorreconocimiento y autopertenencia individuales que encuentran su punto de partida y arranque significativamente en el aislamiento, la exclusión y el ensimismamiento.

Es en el invernadero donde el protagonista se autorreconoce en su apariencia y ser diferente. Y es ahí donde comienza, no por último, su desviación expresa de normas de apariencia. Así, cumple con el implícito mensaje ético que subyace en el lema de Norbu que precede este cuento y en el cual se densifica la paralelización de cuerpo y planta: "Nuestros cuerpos son como árboles bonsái. Ni una hojita inocente puede crecer en libertad, sin ser viciosamente suprimida, tan estrecho es nuestro ideal de apariencia" (ibíd.: 35). De esta manera, los procesos de inclusión -dándose aquí en tanto nociones de una sucesiva autopertenenciase efectúan desde el espacio exclusivo y se conceptualizan como negociación, aceptación y exposición de lo aparentemente diferente. ${ }^{5}$ En estas reflexiones desde el aislamiento elegido, la desviación se insinúa como vía de autoconstitución. Así, el protagonista escenifica un proceso de autoconstrucción productiva de lo extraordinario.

\section{4 “Felina" y "Hongos": formas de inclusión desde el cuerpo mutante}

Tanto en "Felina" como en "Hongos" el cuerpo extraordinario se hace presente como cuerpo mutante que se vuelve a asimilar a medida que sus cambios y transformaciones se hacen visibles y palpables, siendo experimentados en medio y a través de relaciones sociales intrincadas que se constituyen en momentos de comunicación complejos.

5 En estudios del campo de las ciencias sociales y de la sociología se pone de relieve el continuo inclusivo-exclusivo que subyace en cualquier proyecto inclusivo (véanse p. ej. Schlüter 2010: 20 y Farzin et al. 2008: 167). 
Podemos suponer que la primera frase del cuento "Felina", en su corte aforístico, constituye un punto de partida importante para acercarse a la relación particular que se sitúa en su centro narrativo: "Los vínculos entre los animales y los seres humanos pueden ser tan complejos como aquellos que nos unen a la gente" (Nettel 2013: 63).

Una parte de la complejidad, así lo ilustrará el cuento, reside en la dinámica enmarañada de cercanía y distancia que se busca con y, al mismo tiempo, se puede rechazar en el otro, dinámica compleja que -como se verá- resulta, sin embargo, ser catalizadora de procesos de inclusión y de autopertenencia.

Parecido a la situación narrativa en "Bonsái", lo que se muestra en "Felina" es un proceso de acercamiento interorgánico que llega aquí a un nivel aún más intenso y elaborado: se escenifica una comunicación y convivencia entre dos seres vivos - una joven estudiante sin nombre y su gata- cuyas mutaciones corporales - un embarazo paralelo- llegan a tener efectos distintos a nivel tanto emocional como accional.

Así, cuando la protagonista observa a un principio con gusto que "Como el suyo, mi cuerpo cambiaba vertiginosamente" (ibíd.: 72), la conjunción corporal desemboca finalmente en una disyunción tanto física como sentimental cuando la mujer, después de haber perdido a su bebé durante un accidente, entra en un estado de depresión:

Finalmente, me gustara o no, yo también era un animal y tanto mi cuerpo como mi mente reaccionaban a la pérdida de mi descendencia de la misma manera en que lo habría hecho Greta si hubiese perdido a sus gatitos. [...] Dejé de bañarme, de comer y, por supuesto, de pensar en mis estudios. (ibíd.: 77-78)

La paralelización y similitud de estados corporales están sometidas a un cambio abrupto y, en consecuencia, la protagonista entra en un aislamiento profundo, tiende a desconectarse de su entorno social, si bien -y ello da cuenta de la relación ambigua entre mujer y gata- Greta se mantiene en su perspectiva como el ser relevante y unificador que funge como punto de referencia. En este sentido, llama la atención el comportamiento de la gata ante el estado depresivo de la protagonista:

A partir de ese momento, Greta adquirió la costumbre de ponerse en mi regazo a todas horas. Como si instintivamente intentara cubrir con su cuerpo la ausencia del bebé que antes llevaba en el vientre. Esa actitud me provocaba un fuerte rechazo. Su ronroneo me aturdía, y terminaba por echarla al suelo. (ibíd.: 78)

La tendencia de sustituir y llenar la pérdida por parte de la gata -así al menos lo experimenta y percibe la protagonista en una especie de sentimiento proyectivo- nutre la complicada dinámica de cercanía y distancia entre gata y mujer, 
relación que en momentos, y a pesar de sus disyuntivas y del alejamiento parcial, se insinúa como una unidad humano-animal. Así, la evocación del ser híbrido "Felina" culmina en el hecho de que el animal dé a luz a su cría entre las piernas de su dueña. De esta manera, esta llega a sentir el esfuerzo del parto como suyo:

Al despertar, sentí una suerte de ajetreo bajo las sábanas y vi que habían nacido, no en el cajón que con tanto cuidado les había preparado, sino sobre mi propia cama, en el ángulo de mis piernas. El hecho no dejó de impresionarme. ¿Qué tipo de realidad conciben los animales o, por lo menos, qué tipo de realidad concebía mi gata con respecto a mí? (ibíd.: 78)

Es, por lo tanto, fundamentalmente a partir de la dinámica ambivalente de lejanía e intimidad entre la protagonista y la gata que se crea para la figura femenina un espacio finalmente productivo de proyección, (auto)reflexión y autocrecimiento. Así, una vez más, Greta deviene el punto de observación referencial que sabe tranquilizar la protagonista: "Pasé un rato en silencio junto a ella, observándola en su papel de madre orgullosa, como si, en vez de a un instinto, su actitud y sus atenciones respondiesen a un esfuerzo cuyos resultados eran ahora visibles" (ibíd.: 79). En este momento de observación que por su intensidad y el aire de ensimismamiento que conlleva podría llamarse contemplativo se lleva a cabo una especie de antropomorfización de la gata, hecho que le ayuda a la protagonista a reflexionar sobre su estado y de negociar la ambivalente congruencia y diferencia corporal con respecto al animal. Al mismo tiempo, deviene evidente que la protagonista entra en un proceso de (auto)construcción de lo extraordinario. Así, en su observación, al parecer pasiva, crea un espacio para asimilar su mutación corporal múltiple, así como el trauma de la pérdida del bebé. Aquí se abre, por lo tanto, un campo fructífero de reconsolidación y reapropiación emocional, mental y corporal que puede reseñalar las vías de la autopertenencia.

En el cuento "Hongos" la paralelización y comunicación interorgánica se efectúa entre dos cuerpos humanos y, más específicamente, entre dos cuerpos amados. Una vez más nos encontramos con una protagonista sin nombre, una música casada desde varios años hace, que en uno de sus numerosos viajes profesionales al extranjero se enamora de Philippe Laval, un violinista francés reconocido y prestigioso, con el cual comienza una relación amorosa a distancia.

Durante un largo periodo de separación física, un día comienzan a presentarse síntomas corporales en la protagonista:

Aunque estuviera determinada a olvidarlo, al menos a no pensar en él con la misma intensidad, mi cuerpo se reveló a ese designio y empezó a manifestar su voluntad por medio de sensaciones físicas y, por supuesto, incontrolables. Lo primero que sentí fue un 
ligero escozor en la entrepierna. Sin embargo, a pesar de que inspeccioné varias veces la zona, no pude encontrar nada visible y terminé por resignarme. (ibíd.: 96)

Lo que se insinúa aquí primero como cierta rebeldía corporal manteniéndose, sin embargo, invisible se revelará como una micosis. Por lo tanto, la protagonista demuestra una compleja reacción psicosomática que resulta presentarse también en el cuerpo de Laval. La coincidencia de la mutación corporal hace pensarla en términos de una proyección. En este sentido, compartir los síntomas crea una unión particular entre los amantes alejados espacialmente que es experimentada, sobre todo, por la mujer:

Pensar que algo vivo se había establecido en nuestros cuerpos, justo ahí donde la ausencia del otro era más evidente, me dejaba estupefacta y conmovida. Los hongos me unieron aún más a Philippe. Aunque al principio apliqué puntualmente y con diligencia la medicina prescrita, no tardé en interrumpir el tratamiento: había desarrollado apego por el hongo compartido y un sentido de pertenencia. (ibíd.: 97)

Al hacerse presente tanto en otro ser como en el propio cuerpo, el proceso del cambio corporal es observable, deviene comparable y funge como elemento unificador que sabe crear un sentimiento de referencia mutua. A partir de este momento, la enfermedad se establece como importante medio de cercanía y comunicación entre la protagonista y Laval que -valga la paradoja- puede remediar la distancia entre ambos, así como sustituir y llenar la ausencia del otro. Así, la micosis cumple en este cuento una función parecida a la que obtiene la gata en "Felina": ambos 'organismos' devienen en sustitutos a los que se llega a querer porque representan a otro ser perdido. La protagonista en "Hongos" concluye con respecto al hongo: "Seguir envenenándolo era mutilar una parte importante de mí misma. La comezón llegó a resultarme, si no agradable, al menos tan tranquilizadora como un sucedáneo. Me permitía sentir a Philippe en mi propio cuerpo e imaginar con mucha exactitud lo que pasaba en el suyo" (ibíd.).

A través de los hongos que han poblado los cuerpos de los amantes se dan también procesos de concientización tanto corporales como psíquicos. Así, la mutación corporal no es percibida solamente como elemento unificador a nivel interpersonal, sino que - por parte de la protagonista- deviene igualmente en un catalizador de reconfiguraciones y reapropiaciones intrapersonales, hecho que de manera parecida observamos en "Felina". Ello explica la relación particular que la narradora comienza a desarrollar con el organismo invadiente que, aparte de unirla al amado, le posibilita percibir su cuerpo con otros ojos.

Por eso me decidí no sólo a conservarlos, sino a cuidar de ellos de la misma manera en que otras personas cultivan un pequeño huerto. Después de cierto tiempo, conforme cobraron fuerza, los hongos se fueron haciendo visibles. Lo primero que noté fueron 
unos puntos blancos que, alcanzada la fase de madurez, se convertían en pequeños bultos de consistencia suave y de una redondez perfecta. Llegué a tener decenas de aquellas cabecitas en mi cuerpo. Pasaba horas desnuda, mirando complacida como se habían extendido sobre la superficie de mis labios externos en su carrera hacia las ingles. (ibíd.: 97)

La protagonista no solamente acepta la presencia del hongo en su cuerpo, sino que se une con él, se adapta a su presencia que admira y cultiva. Sin embargo, al mismo tiempo, lo limita:

Vivir con un parásito es aceptar la ocupación. Cualquier parásito, por inofensivo que sea, tiene una necesidad incontenible de avanzar. Es imperativo ponerle límites, de lo contrario lo hará hasta invadirnos. Yo, por ejemplo, nunca he permitido que el mío llegue hasta las ingles ni a ningún otro lugar fuera de mi entrepierna. (ibíd.: 100)

Significativamente, es este modo de limitación que la música confiesa experimentar también cada vez más en la relación a distancia con Philippe. "Philippe tiene conmigo una actitud similar a la mía con los hongos" (ibíd.: 100).

Así, el hongo funciona no solamente como síntoma del cambio corporal y de la apariencia diferente de la protagonista que desemboca, no por último, en una desviación de normas de belleza, sino que en su noción de parásito deviene en un símbolo para la cualidad de la relación amorosa. Es a partir de este momento que, además, comienza a explicitarse el sucesivo proceso de autoidentificación que la protagonista lleva a cabo con el parásito, proceso que ya se había anunciado en momentos anteriores del cuento:

Los parásitos -ahora lo sé- somos seres insatisfechos por naturaleza. Nunca son suficientes ni el alimento ni la atención que recibimos. La clandestinidad que asegura nuestra supervivencia también nos frustra en muchas ocasiones. Vivimos en un estado de constante tristeza. Dicen que para el cerebro el olor de la humedad y el de la depresión son muy semejantes. (ibíd.)

Aquí el texto representa el cambio corporal de la mujer como una metamorfosis en cuyo final la protagonista misma aparece como un ser parásito. En su diferencia física se autorreconoce como un organismo invasivo y parece ser justamente a partir de la condición parasitaria que llega a un mayor proceso de autorreflexión durante el cual se enfrenta a sí misma de manera radical: "Hace más de dos años que asumí esta condición de ser invisible, con apenas vida propia, que se alimenta de recuerdos, de encuentros fugaces en cualquier lugar del mundo, $o$ de lo que consigo robar a un organismo ajeno que se me antoja como mío y que de ninguna manera lo es" (ibíd.: 101). Es clave que durante este proceso de autorreconocimiento metafórico la protagonista asimila su transformación como una nueva forma de ser y vivir que lejos de calificarse de privativa o precaria se 
considera hasta agradable. Así, llega a afirmar: "Mi vida es tenue pero no me falta alimento, aunque sea a cuentagotas. El resto del tiempo vivo encerrada e inmóvil en mi departamento, en el que desde hace varios meses no levanto casi nunca las persianas. Disfruto la penumbra y la humedad de los muros" (ibíd.: 102).

$\mathrm{Al}$ igual que en "Felina", el cuento escenifica procesos de transformación corporal que se insinúan como catalizadores, no solamente de una particular relación social y de una compleja situación comunicativa, sino también de aspectos de autorreconocimiento y reapropiación individual. La doble relación que la mujer entabla -con el hongo y con su amante- llega a poner de relieve la heterogeneidad de procesos de construcción de lo extraordinario. Asimismo, revela la multiplicidad de negociaciones a la cual entramos cuando nos encontramos con el otro, con su diferencia así como con nuestra propia desviación. En esta heterogeneidad de (aparentes) disyunciones se multiplican igualmente las vías de la autoasimilación y las nociones de la autopertenencia.

\section{A manera de conclusión}

Los cuentos estudiados negocian normas de corporalidad y evocan modelos de una apariencia de lo incomún que marcan el punto de partida para una escritura de lo extraordinario. Esta escritura se nutre de las expresivas narraciones en primera persona que evocan procesos de proyección, posicionamiento y participación en lo corporalmente 'otro' que en los textos se evoca de múltiples formas: el párpado deforme, la piel de espinas, el animal felino, el bebé perdido, el amante lejano o el hongo invasor. Así, se ilustran pasos de una (auto)construcción de lo extraordinario que coinciden significativamente con procesos de construcción identitaria.

Tanto en "Ptosis" como en "Bonsái", en un principio, los protagonistas hablan y observan desde un afuera. En ello, la mirada y la experiencia vivencial comienzan a proyectarse hacia lo incomún y la proyección excéntrica se vuelve posición elegidamente aislada. En ambos cuentos, la (auto)pertenencia se evoca, por lo tanto, como figura de pensar que implica movimientos proyectivos previos

a distintas tomas de posición. Son dinámicas de pensarse de un 'aquí' hacia un 'allá', las que en "Ptosis" se traducen en la proyección mental y en "Bonsái” se transmiten a través de términos expresadamente espaciales. A nivel textual la cadena tripartita de proyección, posicionamiento y participación destaca momentos alegóricos de la inclusión en tanto proceso dinámico y ambivalente. Lo que ambos cuentos ilustran, en este sentido, es que la inclusión se sitúa en un continuo cuyo polo opuesto, y sin embargo constituyente, radica en la exclusión. 
En "Felina" y "Hongos" la mutación corporal deviene en un medio de comunicación y obtiene un papel importante al modular tanto las relaciones sociales como los procesos de reapropiación individual que se dan al asimilar la autodiferencia. Se escenifica, así, la complejidad y, a veces, la precariedad de procesos de inclusión en su vertiente autocentrada. En ello, la negociación de (auto) diferencias obtiene un papel clave. Así, el establecer tanto la cercanía como la lejanía hacia el propio cuerpo y el cuerpo del otro lleva a procesos de autoidentificación y de unión ambivalentes con el otro. En ello, el otro se representa en ambos cuentos como la diferencia corporal exteriorizada. Además, en la negociación de la autodiferencia se hace presente claramente un 'antes' y un 'después' del cambio corporal que las protagonistas experimentan. De este modo, nos encontramos con notables procesos de crecimiento individual: ilustran la sucesiva autoconcientización que se establece a medida que se observa y siente la mutación física durante la cual la respectiva protagonista llega a habitar su cuerpo nuevamente.

En total, formas de inclusión se representan en "Felina" y "Hongos" en tanto procesos abiertos y a veces precarios de aceptación y autopertenencia que, aparte de enfrentar la (auto)diferencia se nutren de una dinámica dialéctica de distancia y cercanía hacia el otro que aparece en forma del animal, amante, hongo o embrión. Así, ambos cuentos, en mayor medida quizás que "Bonsái” y "Ptosis", meditan sobre las implicaciones de la relación social en constelaciones de autopertenencia e inclusión y defienden la tesis de que para llegar a aterrizar (de nuevo) en nosotros necesitamos al otro.

La mirada proyectiva, el aislamiento elegido así como el cuerpo mutante aparecen, finalmente, como aspectos semánticos complementarios de una narración de la inclusión que Nettel concibe como corriente bajo su escritura de lo extraordinario. Siendo alegorizaciones de una realidad continuamente inclusiva-exclusiva, los cuentos trabajan con una concepción de figuras que permite personificar el carácter constructivo de la apariencia de lo incomún al develar el trabajo imaginario-mental que está por detrás. Los lectores devienen cómplices en un proceso de posicionamientos y autoexperimentaciones cada vez más excéntricos. El saber literario sobre la inclusión se desarrolla, por lo tanto, a través de figuras altamente reflexivas cuyas enunciaciones en primera persona funcionan finalmente como participaciones en lo extraordinario y como actos de habla autoconstitutivos.

En ello resulta clave -y quizás paradójico- que la mayoría de los protagonistas estén sumergidos en el anonimato. Es como si el estar sin nombre multiplicara no solamente el espacio para el trabajo de autorreconocimiento por parte de las figuras sino también la posibilidad de identificación desde el lado del lector. 
Finalmente, el narrador en "Ptosis" se autorreconoce como ser premutilado, el protagonista en "Bonsái" descubre su corporalidad y su mentalidad crasa y las figuras principales en "Felina" y "Hongos" se encuentran y autorreconocen en y durante la mutación corporal. A través de ello, la ficción literaria de Nettel aporta al concepto de la inclusión una reflexión paradójica y también humorística sobre una ética de lo corpóreo que puede ofrecer modelos para actuar y efectuar la autopertenencia.

\section{Bibliografía}

Callsen, Berit. 2018. "Cuerpo, des/uso y subjetivación en Hernández, Bellatin y Nettel”, en: Julio Checa/Susanne Hartwig (eds.), ¿Discapacidad? Literatura, teatro y cine hispánicos vistos desde los disability studies, Berlin: Peter Lang: 223-238.

Checa, Julio/Hartwig, Susanne (eds.). 2018. ¿Discapacidad? Literatura, teatro y cine hispánicos vistos desde los disability studies, Berlin: Peter Lang.

Dederich, Markus. 2007. Körper, Kultur, Behinderung. Eine Einführung in die Disability Studies, Bielefeld: transcript.

Farzin, Sina/Opitz, Sven/Stäheli, Urs. 2008. "Inklusion/Exklusion: Rhetorik Körper - Macht", en: Sina Farzin, Sven Opitz, Urs Stäheli (eds.), Inklusion/ Exklusion: Rhetorik - Körper - Macht, en: Soziale Systeme. Zeitschrift für soziologische Theorie. 14/2, Stuttgart: Lucius \& Lucius: 167-170.

Garland Thomson, Rosemarie. 1997. Extraordinary Bodies. Figuring physical Disability in American culture and Literature, New York: Columbia University Press.

Hartwig, Susanne. 2018. "Introducción: representar la diversidad funcional", en: Julio Checa/Susanne Hartwig (eds.), ¿Discapacidad? Literatura, teatro y cine hispánicos vistos desde los disability studies, Berlin: Peter Lang: 7-21.

Kammeyer, Katharina/Baumert, Britta. 2015. "Inklusion als Narration. Einleitende Gedanken", en: Katharina Kammeyer/Bert Roebben/Britta Baumert (eds.), Zu Wort kommen. Narration als Zugang zum Thema Inklusion, Stuttgart: Kohlhammer: 9-19.

Nack Ngue, Julie. 2012. Critical Conditions. Illness and Disability in Francophone African and Carribean Women's Writing, Lanham: Lexington Books.

Nettel, Guadalupe. 2006. El huésped, Barcelona: Anagrama.

Nettel, Guadalupe. 2008. Pétalos yotras historias incómodas, Barcelona: Anagrama.

Nettel, Guadalupe. 2011. El cuerpo en que nací, Barcelona: Anagrama.

Nettel, Guadalupe. 2013. El matrimonio de los peces rojos, Barcelona: Anagrama. 
Schlüter, Martina. 2010. "Körperbehinderung und Inklusion im Speziellen", en: Sven Jennessen/Reinhard Lelgemann/Barbara Ortland/Martina Schlüter (eds.), Leben mit Körperbehinderung. Perspektiven der Inklusion, Stuttgart: Kohlhammer: 15-32.

Stammberger, Birgit. 2012. "Posthumane Verkörperungen in einer post-Gender Welt? Kulturelle Dimensionen der kosmetischen Chirurgie", en: Miriam Eilers/Katrin Grüber/Christoph Ramann-Sutter (eds.), Verbesserte Körper gutes Leben? Bioethik, Enhancement und die Disability Studies, Frankfurt a. M.: Peter Lang, 181-203.

Waldschmidt, Anne. 2005. "Disability Studies: individuelles, soziales und/oder kulturelles Modell von Behinderung?”, en: Psychologie und Gesellschaftskritik 29 (1): 9-31.

Waldschmidt, Anne/Schneider, Werner (eds.). 2007. Disability Studies, Kultursoziologie und Soziologie der Behinderung, Bielefeld: transcript.

Wolters, Minka. 2014. Besonders normal. Wie Inklusion gelebt werden kann, Bonn: Bundeszentrale für politische Bildung. 


\author{
Katarzyna Nowak-McNeice \\ Universidad Carlos III de Madrid
}

\title{
Autism and the Challenges of Translation: on the Example of Rafal Motriuk's Autistic Son, Desperate Dad (2018)
}

\begin{abstract}
This chapter focuses on a particular example of translating practice centered on a text about autism, which is a father's account of his family's journey to come to terms with his son's diagnosis of autism. The central argument of the text is that autism can be understood as a translating practice itself, and as such it offers an opportunity for the readers to view it not from the perspective of a medicalized, pathologized and stigmatized label, but instead it proposes to view it as a way of being in the world (after Joseph Straus and other critics who stress neurodiversity and functional diversity as necessary components of the world). The comparison between autism and translating practice allows for a broader analysis of what autism understood as culture can offer, when understood not in terms of lack and deficit, but rather as a form of being in the world that has the potential to be enriching.
\end{abstract}

Keywords: autism, narrative, translation, neurodiversity, mode of engagement

Autism was first introduced as a diagnostic category in 1944, and for many decades since then it was understood in terms of a deficit and disconnectedness: the word itself suggests isolation and an inability, perhaps even unwillingness, to bond and associate oneself with others and the world. ${ }^{1}$ This view was challenged when the concept of neurodiversity came into being, which is an assumption that we as humans come in a variety of bodily forms and with a variety of cognitive styles, all of which contribute to the great diversity of life, and are

1 Joseph N. Straus presents the history of the category of autism with two scientists, Leo Kanner and Hans Asperger, coming up with the term at almost the same time in different geographical locations, North America and Europe, in 1943 and 1944. Asperger describes autistic isolation as the most prominent feature of the new diagnostic category, stating that "The autist is only himself (cf. the Greek word autos) and is not an active member of a greater organism which he is influenced by and which he influences constantly" (qtd in Straus, 460). Today this view is challenged: scholars tend to think that autists may have difficulties communicating with the world, but they do not lack a willingness to be a part of a larger world, cf. Olga Solomon (2015) or Hannah Monroe (2018). 
not just desirable but necessary for the world in its complexity and sophistication of design. It is from this perspective that autism emerges as a specific way of being in the world; a way that is not defined by a lack or deficit, a way that is not pathologized, but instead, one that is worthy of the effort of understanding and translation. In this chapter, I offer some remarks on the issues that I propose to see as interrelated, namely, autism in its textual representation and the work of translation; and I propose the following remarks linking them to one example, Rafał Motriuk's Autistic Son, Desperate Dad: How One Family Went from Low- to High-Functioning (2018), and my translation of it. I focus on how the translating practice can help understand autism as a cultural phenomenon, freeing it from the stigma of disability. To do so, one needs to think of the peculiar responsibility of the translator, what Jacques Derrida calls a "beautiful and terrifying responsibility" (2001: 174), which is a predicament of any translator, but especially so when translating a text at the center of which rests the idea of inclusiveness and diversity.

Motriuk's book is a complex work of non-fiction, hybrid in form, including personal essay, journalistic report, poetry, dialogue, dramatic fragments, as well as links to electronic resources and excerpts from other works of fiction and non-fiction. Together, these media make up a mosaic whose aim is a personal, yet journalistically rigorous prose. The non-fictional angle is accounted for not only by the personal experience of the writer, i.e., being a father to an autistic son, but also by his profession, that of a science journalist, and by his activism for social awareness about autism. When his son was diagnosed with autism, the author decided to write a blog, and with his characteristically analytical approach, he explains that the reasons for writing an online journal about his son's autism were threefold: to create a source that in the future might help his son understand himself; to disseminate knowledge about autism; and thirdly, as a form of self-therapy, needed to cope with the difficult reality of his son's condition. The text is based on a blog which "ran for four years and enjoyed 450,000 views" (vii), with additional material added in the process of turning it into a book. The process of translation, then, was itself dual, as it meant an intralinguistic process, in the sense outlined by Roman Jakobson, as well as interlinguistic; which is to say, it involved changing the contents of the blog to a book format, and changing it from the source language, Polish, to the target language, English. But the very experience of caregivers to an autistic person is very often an experience bound with the necessity of translating a highly personal idiolect into a generally agreed-upon version of the language. Thus, autism can be seen as a condition which itself requires and relies upon the praxis of translation, and 
thus it involves intersemiotic translation (the third of the senses of translation distinguished by Jakobson).

The main benefit that derives from seeing a text about autism as involving the three senses of translation, and relying upon them for its meaning, is that we forego the understanding of autism as a static state or a property that some people find themselves in, suffer from, or have, and in its place we gain a dynamic phenomenon where meaning is constantly negotiated and shaped by all participants in the discourse. Such a view aligns with what Hannah Monroe describes as "identity-first language," which we use when we say autistic people instead of people with autism, which points to the difference between the perception of autism as constituting part of one's identity, and not a pathology or illness (n1). Describing autism (and translating a text about autism) with identity-first language matters: not only because it is empowering to the people who identify themselves as autistic as well as their friends and caregivers, but also because it draws attention to the issue of changing classifications of illnesses and conditions as a reflection of societal definitions of norm, health, and the self.

The changes in nomenclature and diagnostic criteria concerning autism emerge as important in the story of a family whose life was turned upside down by the diagnosis, as it is a useful reminder of the beginnings of their narrative of autism and its development. Motriuk begins his journey with the birth of his son, Bartek. Before the diagnosis his family lived in London, where he worked as a correspondent for the $\mathrm{BBC}$, while his wife had a highly successful career at a bank in the city. After the diagnosis they decided to sell their house, quit their jobs, and move back to Poland. This decision was motivated mainly by consideration for their son's therapy requirements: in a dual-language environment, with no support from the family, and rather limited institutional support, the prospects seemed bleak. Poland promised a life a tiny bit simpler, with more structure, and a more extended network of support. The family embarked on a rigorous routine of endless exercises and therapy, with amazing results. The blog, and later the book, documents this progress: of a boy first diagnosed with severe autism, who grew to be a teenager with a diagnosis of being on the highfunctioning end of the autistic spectrum.

The last issue, that of a changing diagnosis, concerns not only the parents' efforts comprising many hours of exercises with therapists and volunteers daily, but it also concerns the classification of autism. The current medical term is Autistic Spectrum Disorder (ASD). The American Psychiatric Association (www.psychiatry.org), which issues The Diagnostic and Statistical Manual of Mental Disorders, the gold standard for illness classification, has redefined autism in its most recent DSM-5 (2013). The previous version, DSM-IV-TR (1994, TR 2000), listed five 
Pervasive Developmental Disorders, among them Autistic Disorder, Asperger's Disorder, and Pervasive Developmental Disorder Not Otherwise Specified (PDD-NOS). The three disorders mentioned are replaced in the latest DSM- 5 by the umbrella term of Autism Spectrum Disorder (www.autism-society.org). As the Association for Science in Autism Treatment explains, autism is defined as "a complex neurobehavioral disorder characterized by impairment in reciprocal social interaction, impairment in communication, and the presence of repetitive and stereotypic patterns of behaviors, interests, and activities" (www.asatonline. org). This classification, needless to say, is still controversial; so is the definition. From the translator's point of view, it poses a problem of whether to follow the most recent guidelines, or, alternatively, treat the issue of diagnosis as part of the history of the disorder.

In fact, some specialists agree that the reasons for re-classification may not be entirely scientific: Barbara Garrick and her colleagues call autism a "slippery term" (121), while Joseph N. Straus reaches to the very origins of the classification, saying that when Kanner and Asperger created the new category of autism, they "participate[d] in the endless reshaping of the map of psychological disorders, which rise and fall historically, as much in response to cultural and social pressures as to any neutral, scientific observation." Straus adds that despite the wide acceptance of the term, autism is "as historically and culturally contingent as neurasthenia, hysteria, and fugue - science based and neutral medical categories of a previous era" (536). For a translator of a text about autism, the decision to describe it as either a condition, or an illness, or to use another term such as spectrum, is a decision bound by the faithfulness to the original on the one hand and by the desire to use current terminology on the other, the latter motivated by the belief that it reflects the ability of the language itself to shape and form the reality of the people who can be either hurt or empowered by it.

These questions, pulling the work of a translator in two opposing directions, approach ethical questions that look back to an age-old dictum describing the translator as a traitor: traduttore, traditore. A similar point is made by Emmanuel Levinas, who liked to point out "Traduire, c'est trahir (to translate is to betray)," but, as Simon Critchley adds in his commentary on Levinasian ethics, "the translation of the saying into the said is a necessary betrayal," where the said is a statement whose truth content can be assessed and ascertained, while the saying is an ethical situation of the content being conveyed to a particular interlocutor, an "ethical residue of the language that escapes comprehension" (18-19). The idea of a necessary betrayal that constitutes a fundamental condition of any given translation underlines the ethical component of translation and specifies its central problem. How does one balance between fidelity, understood not just 
as a faithfulness to the letter, to the text, and to the spirit of the original, but also as loyalty to the person behind it on the one hand, and what emerges as a betrayal constitutive of and an inherent element of a transfer between the content in one language and culture and the next?

Derrida underlines a similar problem when he points to the double meaning of Aufhebung in Hegel, which simultaneously suggests preservation and erasure, stating his belief that all translation is a paradoxical balancing act between translatability and untranslatability. He says, "all translation implies an insolvent indebtedness and an oath of fidelity to a given original - with all the paradoxes of such a law and such a promise, [...] that is, moreover, impossible and asymmetrical, [...] like an oath doomed to treason or perjury" (183). This precarious situation, the act of translation, resembles what Homi Bhabha calls the Third Space: the space of cultural translation which requires that the language becomes hybrid, resisting authoritarian domination. It is in this space where the governing principles are hybridity, fluidity, and transformation, rather than adaptation of one to the terms of the other and under the domination of the other.

My insistence on fluidity and resistance to cultural domination parallels an understanding of autism as culture (after Straus). When Bhabha discusses the liminality of translation, he stresses the "element of resistance," or, to quote Walter Benjamin, "that element in a translation which does not lend itself to translation" (224). Autism, in this context, might be seen as performing the culture's "untranslatability." This approach lifts from autism the stigma of a pathology or a deficit that is attached to it in the medical models. The task of the translator then appears as that of a cultural mediator who has to translate the untranslatable, at the same time undertaking the impossible ethical oath of fidelity.

This view is only implicitly represented in the text, which comes close to the understanding of autism in terms of neurodiversity in the sense that Straus uses the word, that is, "a belief that autism is not a defect or pathology, but rather an aspect of naturally occurring and inherently desirable human variability" (467). Even though Autistic Son implies that autism is "a way of being in the world" (Straus 467), it is not, however, the view explicitly represented by the author of the book: rather, because of the personal and social specifics of the task as

2 Roman Jakobson, in his classic study of translation, poses other questions that relate to the same equation between translator and traitor, asserting, "a cognitive attitude would compel us to change this aphorism into a more explicit statement and to answer the questions: translator of what messages? betrayer of what values?" (238). These questions prompt us to consider the values implicit in a given definition of autism, when considering a translation of a text about autism. 
a caregiver to an autistic child, Motriuk talks about his son's "disability" in the following way: "I don't think disability is something negative. [...] To me, if it occurs in nature, it's normal. Some phenomena just occur more often, some less so"; and he continues to explain his son's condition: "Bartek is disabled. $\mathrm{He}$ requires help. That's obvious. I have it in writing. I don't think there's any discussion here" (129-130). He refers here to the official medical statement of disability that guarantees certain medical aids, such as access to therapy, which is indisputably beneficial. The question that he recognizes as more pressing, however, is announcing to the child his "disability" in such terms.

This issue becomes contentious in an exchange with a parent after a situation in which Bartek's social skills appear no different from other children. The father is tempted to ask, "Did you notice [...] that my son is disabled?", which is followed by his son's outburst: “'I am not disabled!' Bartek screams before she manages to open her mouth" (129). The seven-year-old clearly displays a willingness to control the label attached to him, which, in turns, prompts the author's reflection on the issue, followed by a footnote in which he explains the evolution of his view on the matter of ASD and disability: "I would now see them as separate but overlapping categories - if the autism is profound enough it could be considered a disability" (130n30). This admission shows that for the author, his personal understanding of ASD, informed by the changing medical categories and cultural standards, has undergone a transformation that parallels the one that his family was experiencing. The dynamism of the situation, its fluidity and changeability, critically shapes the text and, perhaps needless to say, influences the translation.

In the text, this moment of self-reflection on the part of the boy shows the dramatic change that he has undergone, from a non-communicative child with obsessive behaviors, typical of people on the spectrum, such as flapping their arms, echolalia, uncontrollable screams, and tantrums, to a child capable of accepting or refusing a label supposed to describe him. Rafal, the father, describes the difficult beginnings, mentioning the routine to teach his child to simply imitate: "As instructed, I would take his face in my hands and say, 'Bartek, do as I do', and I would put my finger to my nose. [...] At first Bartek, a three-and-a-halfyear-old, did not react at all" (5). Days or maybe weeks later - the parent's hesitation on the exact passage of time is indicative of the effort here - Bartek finally does what he is asked to do, and the author describes the feeling as "ecstatic" (5), despite realizing the developmental gap between his son and his peers who are "able to tell their parents about their day at preschool" (5).

On the fifth anniversary of the diagnosis, Rafał is able to write: "Five years ago, our then three-year-old, wearing a diaper, was occupied with three things 
only: pouring water, pouring sand, and turning lights on and off. (Oh, and running non-stop, of course.) There was no guarantee this child would ever learn to button his shirt, spell, or have any meaningful dialogue" (151). Fast forward five years, and Bartek "is taking part in an interschool competition for first graders. He was chosen after winning a competition against his peers (i.e., his classmates)." Rafał is able to finish this paragraph triumphantly, "That's where we are today" (151), and it is no small feat.

Despite the obvious reasons for celebration, Bartek is still on the spectrum and he displays what might be viewed as the difficulties typically described as the Dyad of Impairments. As the Association for Science in Autism Treatment explains, the dyad in DSM-5 means "impairment of social interaction and communication [...] and restricted repetitive and stereotyped patterns of behavior" (www.asat.org). The Dyad of Impairments is a reduction of what was previously known as the Triad, with now the two categories of social interaction and communication combined. ${ }^{3}$

An example illustrating the impairment of social interaction would be a conversation that Bartek had with his dad, in a park, sitting on a bench next to a couple on a romantic date. Bartek pays no attention to their hugging and kissing, instead asking his dad such questions as, "Dad, do ducks poop in the water? Does a duck poop out the remnants of food? Do I poop out the remnants of food?"; to finish with a request, "Dad, let's talk about vomit now" (120). While any neurotypical child might want to talk about poop and vomit, Bartek's behavior may be interpreted along the lines of autistic impairment, which is that his conduct differs in his lack of awareness of the coincidental audience and his lack of consideration for physical distance, of which he needs to be instructed in a way that children not on the spectrum just learn instinctively.

On the other hand, however, Bartek comes up with ingenious ways to help him cope with social interactions that swerve in a direction he does not tolerate. One example is when a therapist leaves later than scheduled, or stays to chat

3 Elizabeth Fein describes the perception of autism in terms of lack in the following way: "The autistic cognitive style, and particularly the challenges that come with it, have traditionally been depicted as a series of individual deficits in executive function, theory of mind, central coherence. Inabilities to organize, to intuit, to infer, without explicit guidance;" she adds that this perception is, however, changing: "Sometimes these qualities are understood less as individual deficits, and more as personal styles" (131). Jurandir Freire Costa and Roy Richard Grinker state that "in conventional psychiatric nosology, so-called cognitive, affective, sensory, and communicational deficits are viewed as pathognomonic signs of autism" (158). 
with Bartek's parents: Bartek does not appreciate such changes in the daily routine. When saying goodbye, asking them to leave, or simply pushing them out of doors does not bring the desired results, Bartek sits at the piano and improvises a lullaby: "Julia/Dominika/Go home/It's time to go to bed/It's so very late/Tra la la/Good night" (119). His obvious inventiveness goes against the social rules, although the charm of this method of obtaining what he wants is sure to allow him to be excused.

If, however, instead of focusing on the Dyad of Impairments, we attempt to think of autism as a particular way of being in the world (Straus), as a difference, not a deficit, then it is possible to see the peculiarities of cognitive processes as a creative way of manifesting a specific worldview. We might then see Bartek's obsessions and logic not as a reduction of his engagement with the environment, but as a method of organizing the world and being involved in it. Rafal states that from a neurotypical witness's point of view, "an autistic person's way of thinking can be painfully precise, logical, and exact," giving as an illustration Bartek's answer to the question of who he wants to be when he grows up. The answer, with Bartek raising his eyebrows at the lack of logic of those who ask him that, is that he wants to be Bartek (34). It is also a subtle way of suggesting that there is no Bartek without autism; there is no autistic person in which a non-autistic person is trapped (to use the phrase proposed by Charlotte Moore). Each of the examples presented, i.e., talking about the physiological needs of ducks, improvising farewell songs, answering queries about the future, might be either seen as an instance of a certain deficit, in social or communication skills, but they might also be representative of a particular logic governing the way of thinking, that might be seen as non-neurotypical, but internally logical, nevertheless.

This logic sometimes means that the world appears chaotic and disorganized. “'Is there Ger-much?' Bartek asks. 'No, Bartek, there's Ger-many.' 'There should be Germuch if there's Germany,' says Bartek." Rafał can only ask, "How can you argue with such logic?" (154). The translator's task, and necessarily also the reader's, when faced with a text representing such a way of thinking, is to try to see the world from a different angle - which in itself is a luxury that literature affords us. In the Polish original, the word for Germany is Niemcy, which includes a negating particle nie, so Bartek's logic is that if there is a word containing a negation, then there must also be a word without the negation, $M c y$, which is a non-existent word (just like its translated equivalent, Germuch). The rhetorical question that Rafal poses suggesting the inability to denounce the logic demanding the existence of Germuch (Mcy) is what the reader is inclined to agree with. The reader's and the translator's agreement with the autistic logic signals an openness to accept autism as a way of being in the world, rather than as 
a deficit. In the same vein, Elizabeth Fein describes autism as "a mode of engagement with [...] the world", which also means, as she explains, that "What we say and do about autism, therefore, also tells something about how we relate to these surroundings of ours" (130, italics in the original). It might be thus understood as a translational practice by which our understanding of autism translates into our engagement with our environment, which frees it from the medicalized, pathologized perception as a lack and deficit.

Rafał stopped writing his blog when Bartek was nine years old, on his son's explicit demand. In the Epilogue of the book, he explains that at sixteen years old, Bartek gave him permission to publish the contents in book form. "My dream, my hope and my anticipation is that Bartek, at some point in his life, will provide some sort of continuation," he says, adding, "But it needs to be his own creation and his own writing" (181). This book provides a clear indication that Bartek, like other autistic people, is capable of creating his own narrative, one that integrates the difference, without normalizing it or reducing it to a deficit. This capability is evidenced in Bartek's Foreword, in which he says:

I let my Dad publish this book because if you're autistic, you can thrive even better than people with no autism. I think that my autism will help me become a computer programmer and IT tech engineer. [...] I am sure this book will help parents of autistic children to worry less and encourage their kids to become IT techs and programmers. (v)

These words are not only an indication of Bartek's ability to shape his own narrative, but they also provide testimony for Bartek's ability to see certain events from other people's perspective, here from the point of view of the parents of autistic children, and his capability for empathizing with them, namely, understanding their preoccupation with their children's futures. But perhaps most importantly, Bartek's words stress the fact that an autistic person is not defined by what they cannot do or achieve, but what autism makes possible and how it can be translated into an advantage. Straus points out that "for a new generation of people with autism, it is not about what they can do despite autism (not about overcoming), but about what autism enables them to do, what they do through and with autism" (475). In Autistic Son, Desperate Dad, this idea comes through very clearly. For Bartek, and for other ASD people, being on the spectrum means seeing the world differently, and there lie the inherent value and beauty not just for them; it is a manner of being in the world that has the potential to enrich us all.

\section{Bibliography}

Benjamin, Walter. 1969. “The Task of the Translator", en: Illuminations. Trans. Harry Zohn, ed. \& intro. Hannah Arendt, New York: Schocken. 
Bhabha, Homi. 2004. The Location of Culture, New York: Routledge.

Critchley, Simon. 2009 [1999]. Ethics-Politics-Subjectivity: Essays on Derrida, Levinas, and Contemporary French Thought, London: Verso.

Derrida, Jacques. Winter 2001. “What Is a 'Relevant' Translation?", en: Critical Inquiry. Trans. Lawrence Venuti, 27: 174-200.

Fein, Elizabeth. 2018. "Autism as a Mode of Engagement", en: Elizabeth Fein/Clarice Rios (eds.), Autism in Translation: An Intercultural Conversation on Autism Spectrum Conditions, Cham: Palgrave Macmillan.

Freire Costa, Jurandir/Grinker, Roy Richard. 2018. "Autism and First-Person Accounts: The Cognitive Problem", en: Elizabeth Fein/Clarice Rios (eds.), Autism in Translation: An Intercultural Conversation on Autism Spectrum Conditions, Cham: Palgrave Macmillan.

Garrick, Barbara/Winter, Satine/Sani, Mahbuba/Buxton, Lynn. 2015. "Managing the Barriers in Diversity Education That We Create: An Examination of the Production of University Courses about Diversity", en: Tim Corcoran/Julie White/Ben Whitburn (eds.), Disability Studies: Educating for Inclusion, Rotterdam: Sense: 117-136.

Jakobson, Roman. 1959. "On linguistic aspects of translation", en: Achilles Fang/Reuben A. Brower (eds.), On Translation, Boston: Harvard University Press: 232-239.

Monroe, Hannah. 2018. "Ableism, Speciesism, Animals, and Autism: The Devaluation of Interspecies Friendship", en: Lori Gruen/Fiona Probyn-Rapsey (eds.), Animaladies: Gender, Animals, and Madness, London: Bloomsbury. Kindle version, np.

Moore, Charlotte. 2012 [2004]. George and Sam, London: Penguin.

Motriuk, Rafał. 2018. Autistic Son, Desperate Dad: How One Family Went from Low- to High-Functioning, Wrocław: Prebonus Publishing.

Solomon, Olga. 2015. “'But-He'll Fall!': Children with Autism, Interspecies Subjectivity, and the Problem of 'Being Social"', en: Culture, Medicine and Psychiatry 39 (2): 323-344.

Straus, Joseph. 2010. "Autism as Culture", en: Lennard J. Davis (ed.) The Disability Studies Reader, 4th. ed., New York: Routledge: 460-484.

www.asatonline.org, the Association for Science in Autism Research. www.autism-society.org, the Autism Society of America. www.psychiatry.org, the American Psychiatric Association. 


\section{Inclusión y narración}





\title{
Susan Antebi \\ University of Toronto \\ Transparencia jurídica y escritura corporal: una mirada oblicua a Carta sobre los ciegos de Mario Bellatin
}

\begin{abstract}
The concepts of inclusion and transparency tend to share an emphasis on visual metaphors and on images of movement and communication through physical barriers. Recent Mexican legislation on transparency and the inclusion of disabled people reveals an intertwining of these concepts, as well as the notion that these are achievable goals that will enforce accountability and improve equality for all. This chapter provides a context for the juridical notions of transparency and inclusion in Mexico and discusses a recent case of sexual abuse and forced sterilization of women with psychosocial disabilities in Mexico City, arguing that the role of disability as embodied material difference complicates the twin models of transparency and inclusion, specifically when the body becomes central in new ways to the transmission of information. Then, the chapter turns to the analysis of Mario Bellatin's novel, Letter on the Blind for the Use of Those Who Can See, focusing on the intimate ties between disabled embodiment and communication, and the ways in which this material aesthetics of writing and of the reception of knowledge further complicates the notions of clear communication, translatability, and social inclusion. In these readings, the materiality of disability is key to rethinking the relationships between bodies, knowledge, and social justice. Disability is not strictly a matter of human rights, nor of literary representation, but rather a dynamic facet of human experience within and between the spaces of art and politics.
\end{abstract}

Keywords: transparency, inclusion, Mario Bellatin, disability, Mexican law

El lenguaje que nos invita a absorber y comprender su mensaje de manera inmediata, sin mayores rodeos, se describe con frecuencia como transparente. Entrar al espacio compartido por otros lectores y participar en la recepción de significados a nivel colectivo sugiere el acceso a lo que contienen las cifras de la lengua; en otros términos, ser incluido en una comunidad delimitada por la escritura en abstracto, y una serie de palabras en particular. La metáfora espacial de una escritura a la cual se accede por la acción de entrar, atravesando una frontera, nos podría recordar que es también común pensar el acceso al sentido del lenguaje por medio de una metáfora visual. La entrada al espacio privilegiado del mensaje se accede por la acción de los ojos, su movimiento y focalización hacia el otro lado de la pantalla implícita que divide el mundo que conocemos del mundo que 
estamos a punto de conocer, y que separa también la exterioridad de las palabras de su sentido interior.

Entrar al espacio de la escritura o del lenguaje por medio de estos procesos metafóricos implica desplazar el cuerpo entero, o solo los ojos; la transparencia relativa de la pantalla o barrera que delimita la entrada, facilita la accesibilidad e inclusión para un público más amplio y más diverso. En este sentido, se puede considerar un contacto íntimo entre las nociones de transparencia y de inclusión. Ambas dependen aquí de una metaforización del proceso de acceder a fuentes de información y otros recursos, y ambas proponen un movimiento y una barrera que sirve a su vez como puerta, ventana, o en algunos casos, espejo. ${ }^{1}$ En el presente texto me enfoco en los conceptos interrelacionados de transparencia y de inclusión para considerar no solamente sus funciones poéticas y los problemas que sugieren en cuanto a la materialidad de la escritura, sino también su relevancia en los discursos legales y estatales de las últimas décadas en México.

Como describe Rancière, no es tan sencillo distinguir la supuesta transparencia de la prosa o del lenguaje comunicacional y separarla de un lenguaje poético en el que las palabras se utilizan "como cosas," según pretendía Sartre. En este sentido, la noción de la transparencia como característica deseable y que promueva el acceso y la inclusión en el lenguaje se complica en seguida. "La función comunicacional y la función poética del lenguaje, en efecto, no dejan de entrelazarse, tanto en la comunicación ordinaria, en la que pululan los tropos, como en la práctica poética, que sabe desviar enunciados perfectamente transparentes en beneficio propio" (Rancière 2011: 19). Para el autor de Política de la literatura, la literatura interviene en un "reparto de lo sensible," entendido como proceso de determinaciones de lo visible y lo invisible, y de las formas de actuar y de nombrar el mundo, que cambia en distintos registros y momentos históricos (20-21). La transparencia y la inclusión, lo que los textos dejan ver o entender, y lo que se permiten decir, por lo tanto, no son conceptos fijos, sino que obedecen a las tendencias sociales y estéticas de su momento. ${ }^{2}$ No se privilegia aquí un concepto de

1 Román Echeverri señala ciertos puntos de contacto entre la transparencia y el reflejo en su análisis de obras de arte y de las propiedades físicas de la luz, los cristales y los espejos. Apunta además que el ojo puede ser considerado el primer espejo, por su manera de captar la luz y reflejar una realidad (66).

2 Cabe señalar que para Rancière, tanto en Política de la literatura como en otros textos suyos, el término "política" no se refiere al manejo cotidiano de leyes y poderes, ni a los procesos electorales, sino a momentos concretos en que "esos o esas que no tienen el tiempo de hacer otra cosa que su trabajo se toman ese tiempo que no poseen para demostrar que sí son seres parlantes, que participan de un mundo común, y no animales furiosos o doloridos" (16). 
transparencia como lenguaje "claro," ni tampoco una función poética de lenguaje "petrificado." Más bien se trata de analizar los entrelazos y el equilibrio volátil entre diversos usos del lenguaje, sus efectos, y sus momentos de ajuste o cambio radical. De manera similar, en mi lectura, basada en conceptos de transparencia e inclusión dentro y fuera del contexto literario en México, me interesa complicar las ideas de transparencia y de inclusión, y recalcar las tensiones e inversiones de los procesos que ponen en movimiento. El papel de la discapacidad, y la materialidad del cuerpo, en relación con las nociones de inclusión y transparencia en el México contemporáneo se vincula íntimamente con los procesos de comunicación y sus movimientos literales o metafóricos, revelando a veces nuevos repartos entre cuerpos, agencia subjetiva, y medios de información.

El vínculo que posibilita esta lectura entre una poética literaria de la (siempre relativa) transparencia incluyente, y los modelos más prácticos de transparencia y de inclusión propios del ámbito legal sirven a su vez para pensar el lugar y función de la discapacidad en la producción cultural mexicana de años recientes. Los problemas de la transparencia y la inclusión en sus diversas vertientes, tanto legales como poéticas, nos demuestran que el tema de la discapacidad no se limita a un dilema de representación literaria o política, ni a una definición de derechos, sino que activa un movimiento entre diversos espacios y lenguajes. Si la transparencia implica la presencia de un medio (un cuerpo, pantalla u otro objeto) por el cual algo se revela, podemos preguntarnos cómo el medio influye en los seres humanos que se acercan a él, en los cuerpos que se sitúan a ambos lados de esta frontera, o incluso en los cuerpos que sirven como medio, y en particular si se trata de personas con discapacidad. Más aún, habría que tomar en cuenta de qué manera la información y su transparencia en sí se encuentran imbricadas en las historias, formas y experiencias de la discapacidad, las diversas maneras de ser y de comunicarse en el mundo.

En este texto quisiera plantear la noción de la transparencia a partir de una lectura doble, que entrelaza las metáforas del ámbito legal con las del contexto literario, en ambos casos basada en la presencia y acción de la discapacidad. Inicio con una contextualización del uso político de la transparencia, de los discursos de la inclusión en México, y su relevancia a nivel global a partir de las últimas décadas del siglo veinte. Luego, considero un caso mexicano más específico en el cual el problema de la transparencia en casos de abuso sexual de mujeres con discapacidad adquiere una corporalidad literal. La tercera parte de mi análisis se centra en la obra literaria de Mario Bellatin, y en particular en su novela, Carta sobre los ciegos para uso de los que ven. Como varios otros textos del mismo autor, esta novela, que toma su título del tratado filosófico clásico de Denis Diderot, gira alrededor de los temas de lo visual y la ceguera, y de las complejas estructuras de 
inclusión y exclusión, muchas veces determinadas por la experiencia y la materialidad de la escritura y la corporalidad de los personajes. No es mi intención sugerir que exista un vínculo directo o intencional entre la producción literaria de Bellatin y las nociones de transparencia, inclusión y acceso en los discursos públicos y legales en México de las últimas décadas. Más bien propongo destacar el papel dinámico de la discapacidad en un espacio de análisis crítico que yuxtaponga los dilemas estético-literarios con los de índole legal y social. Esta lectura pretende entender mejor las limitaciones de los modelos actuales de la transparencia y de la inclusión, y considerar los procesos que se activan cuando se plantea la discapacidad como experiencia corporal y modelo transformativo y fluido en-y entre- los ámbitos del arte y de la política.

El discurso de la transparencia en México tiene sus orígenes en el concepto de derecho a la información, que fue concebido como derecho humano a nivel internacional en la declaración de las Naciones Unidas de 1948 (Escobedo Romero y Rivera Aguilera 51-52). La institucionalización del acceso a la información como derecho no se limita al ámbito mexicano, ya que los casos de legislación a favor del acceso público a ciertas categorías de información estatal llegan a ser más comunes a nivel mundial a partir de la segunda mitad del siglo veinte. ${ }^{3}$ En el contexto mexicano, una enmienda de 1977 a la Constitución de 1917 le agrega una sola cláusula al artículo seis, sobre la libertad de expresión, que ahora incluye el 'derecho a la información, garantizado por el Estado' Y en 1996, la Corte Suprema de Justicia de México extiende el derecho a la información al derecho de saber la verdad, prohibiendo que las autoridades estatales impartan información falsa, incompleta, o manipulada (Cortés Ontiveros 18-19).

Es en el año 2002 cuando el discurso de la transparencia adquiere mayor impacto en México, con la primera Ley de la Transparencia, firmada por el presidente Vicente Fox. La ley garantiza el acceso público a la información gubernamental, incluyendo información perteneciente a individuos, organizaciones, partidos políticos y otras entidades que reciben fondos federales (Ley federal). El momento político de Fox, como primer presidente del Partido de Acción Nacional (PAN), es significativo porque su elección marca la primera vez que un partido que no fuera el PRI gana la presidencia desde 1910 (Saúl). Sin embargo, también habría que destacar la importancia de la participación de la sociedad

3 Escobedo Romero y Rivera Aguilera mencionan como antecedente importante los Freedom of Information Acts de Estados Unidos y de Inglaterra (44), y en el contexto latinoamericano más reciente, se refieren a la legislación en Colombia, Perú, Chile, Argentina, y México, países que forman parte de la Red Latinoamericana de Transparencia Legislativa (47). 
civil en el proceso de investigación que conduce a la nueva legislación, y en particular el llamado Grupo Oaxaca, compuesto de periodistas e intelectuales (Salazar Rebolledo 1173; Cortés Ontiveros 23). El énfasis en una cultura de la transparencia se articula desde el poder político y de sectores de la sociedad civil como parte de una lucha en contra de la corrupción, y a favor de una apertura hacia la democracia. Cortés Ontiveros señala un vínculo entre la promoción de la transparencia en México a partir de los años 70, y la reacción del público frente a instancias de violencia e impunidad estatal: "La sociedad civil está exigiendo la cancelación de cualquier forma de expresión de autoritarismo gubernamental; el esclarecimiento de hechos históricos como los ocurridos el 2 de octubre de 1968 y el 10 de junio de 1971, y la tristemente llamada guerra sucia, son claros ejemplos de ello" (Cortés Ontiveros 16). Aunque la legislación mexicana, sobre todo de las últimas dos décadas, establece las pautas para un acceso más democrático a la información pública, sería difícil argumentar que esta tendencia haya logrado una reducción en la violencia o en la impunidad estatal a largo plazo. ${ }^{4}$

El tema de la transparencia figura de manera prominente en sitios de internet de instituciones gubernamentales y de organizaciones que reciben fondos públicos. En el año 2009, la estación del metro cercana al nuevo Instituto de Acceso a la Información Pública recibe el nuevo nombre, "Plaza de la Transparencia" (Robles). De esta manera la transparencia permea paisajes materiales y virtuales y permanece como elemento clave del discurso público. Si bien la noción de la transparencia tiende a referirse en particular a cuestiones de finanzas, se vincula también a las diversas funciones estatales, sus dependencias, y sus posibles compromisos con la violencia y la represión que con frecuencia se revelan por medio del rastro del dinero.

Durante los sexenios de los presidentes Fox y Calderón se privilegia el tema de la transparencia gracias a una serie de leyes e iniciativas a nivel federal y estatal, empezando con la ley de 2002. En la misma época en México las personas con discapacidad adquieren una mayor presencia jurídica, por medio de la Ley Federal Para Prevenir y Eliminar la Discriminación, de 2003, la Ley General para Personas con Discapacidad, la Convención de las Naciones Unidas sobre

4 Oswaldo Zavala asocia la violencia en México y en espacios fronterizos con la soberanía estatal y su control disciplinario, sobre todo a partir de la presidencia de Calderón (42). Para otros críticos, como Sayak Valencia, la violencia actual en México y otros espacios debe de entenderse como elemento íntegro al capitalismo global. Pero incluso desde la perspectiva de una violencia arraigada en fenómenos mercantiles, incluyendo el narcotráfico, resultaría problemático no tomar en cuenta el entremado de intereses estatales y paraestatales como productor y participante de la violencia y su espectacularización. 
los Derechos de las Personas con Discapacidad, firmada en México en 2007, y la Ley General para la Inclusión de las Personas con Discapacidad, de 2011. ${ }^{5}$ Es curioso notar el énfasis simultáneo en los discursos de transparencia y de inclusión, ambos articulados como derechos humanos que se puedan proteger desde espacios jurídicos estatales y transnacionales, sobre todo porque son discursos que entran en contacto mutuamente, pero sin la intención explícita de formar parte de una sola iniciativa.

Los espacios de internet dedicados a los recursos de la transparencia y de la inclusión nos ofrecen los ejemplos más concretos de la simbiosis entre las dos áreas. En las páginas de agencias gubernamentales, es inevitable la presencia de íconos para guiar el usuario hacia recursos sobre la transparencia, o cómo acceder a diversas fuentes de información, y cómo proceder cuando dicho acceso, garantizado por la ley, ha sido negado. De la misma manera y en los mismos espacios, la accesibilidad y la inclusión garantizadas por la ley se representa y se materializa por medio de herramientas técnicas en las mismas páginas de internet, que les permiten a los usuarios con diversas formas de discapacidad acceder a la información que buscan. El doble énfasis en transparencia e inclusión incorpora ambas tendencias en un discurso autorreflexivo, en el cual la accesibilidad de la información se define por su iconicidad, como presencia tangible que vincula el usuario con los datos solicitados. ${ }^{6}$ Es en este sentido que se puede hablar de una política de inclusión transparente, o de transparencia incluyente a nivel discursivo. La unidad parcial que se crea entre los términos se acerca también a la dinámica necesaria entre lo ontológico y lo epistemológico. No es solamente que los hechos de inclusión operan o se disfrazan de acuerdo con lo que sabemos sobre ellos, es decir su transparencia. Además, la operación se invierte cuando los mecanismos de transparencia dependen de su capacidad para ser realmente incluyentes. Ninguno de los dos polos ocupa un espacio de privilegio de forma permanente, sino que oscilan en una relación de dependencia mutua.

La estructura algo abstracta por la cual la transparencia y la inclusión se juntan adquiere cierto grado de concreción debido a la tendencia legislativa común que inscribe a ambos discursos dentro de un concepto más amplio de derechos humanos, con una trayectoria mexicana e internacional sobre todo en las últimas dos décadas. Sin embargo, la transparencia incluyente, o inclusión transparente, se materializa de manera mucho más explícita por medio de casos particulares

5 Ver Secretaría de Gobernación.

6 Para un ejemplo, ver: Instituto de Transparencia, Acceso a la Información Pública, Protección de Datos Personales y Rendición de Cuentas de la Ciudad de México. 
de la discapacidad, o momentos en que la corporalidad humana de la discapacidad entra en contacto con instituciones sociales y políticas, o emerge en la representación literaria, como quisiera demostrar a continuación. Además, estos casos revelan ciertas limitaciones del modelo de derechos humanos, sobre todo porque tienden a emerger en espacios de precariedad, en donde se distinguen los bordes de la categoría de lo humano, su incapacidad para abarcar formas inesperadas de la diferencia.

Mi análisis de la discapacidad en contacto con el dilema de la transparencia y la ley, se centra en la atención que han recibido casos de esterilización forzada y abuso sexual de mujeres con discapacidad psicosocial en la Ciudad de México. En este contexto, el valor relativo adscrito a la persona con discapacidad, su cuerpo y su futuro reproductivo se construyen junto con formas particulares de la transparencia como noción de verdad. La lógica imperativa de la esterilización forzada o voluntaria de la mujer con discapacidad obedece a un concepto del cuerpo femenino en que la ausencia de signos visibles de embarazo significa la ausencia de actividad sexual, y sobre todo la ausencia de impropiedad, por lo menos en la superficie. Al mismo tiempo, aceptar esta lógica implica privilegiar las apariencias por encima de otra información. La noción de una esterilización necesaria sugiere que ni los asaltos sexuales a las mujeres con discapacidad ni su libertad sexual tenga importancia o siquiera existencia real, con tal de que no haya huellas físicas (embarazos) en el cuerpo femenino. Esta lógica obedece a lo que llamo una verdad integrada, definida como instancia de violencia, corrupción o impropiedad que se tolera o se ignora debido a las condiciones de transparencia por medio de las cuales aparece. En este caso no es simplemente que sea conveniente hacer caso omiso a la violencia que no se ve, sino que existe una relación material entre el hecho violento y la falta de evidencia, la transparencia perfecta que no revela nada. El valor del cuerpo de la mujer con discapacidad aquí se define por su incapacidad de producir señales de violencia; se sabe que ha sido esterilizada y no podrá embarazarse. Se hace transparente este valor debido a un reconocimiento general en algunas instituciones mexicanas que la esterilización a las mujeres con discapacidad es la mejor práctica. En este contexto, el director de una institución para jóvenes con discapacidad en la Ciudad de México declara, "Todas las chicas tienen que esterilizarse" (Rosenthal 19).

En 2015, la organización de mujeres con discapacidad psicosocial Colectivo Chuhcan, en colaboración con Disability Rights International, (DRI) publicaron los resultados de su investigación acerca de la esterilización de mujeres con discapacidad psicosocial en la Ciudad de México. El estudio fue relativamente pequeño, incluyendo solamente a 51 mujeres, y sin datos de mujeres institucionalizadas, debido a la dificultad en accederlas para entrevistas. Los resultados del 
estudio demostraron que un alto porcentaje (42\%) de mujeres con discapacidad psicosocial que habían recibido servicios de salud institucional habían sido esterilizadas forzosamente o debido a presión de sus familiares. El mismo porcentaje de las mujeres habían sido abusadas por un ginecólogo. La explicación por parte de las investigadoras no se basa solamente en la percepción todavía común de que las personas con discapacidad no deben de reproducirse. Los profesionales de la medicina y los familiares de las mujeres sí afirman en muchos casos la creencia de que las mujeres con discapacidad no pueden ser buenas madres, y que hay que evitar el riesgo de la herencia (20). Sin embargo, una segunda razón hecha explícita en el estudio a favor de la esterilización se basa en el reconocimiento de la inevitabilidad del abuso sexual de personas con discapacidad, sobre todo en contextos institucionales (21). Un reporte anterior de DRI (2010) encontró amplia evidencia de muchos casos de abuso sexual. Además, el personal médico y las mismas mujeres emplearon la explicación de la esterilización como medio de protección frente a los asaltos. En este sentido, la lógica de la esterilización se deriva de una combinación de estos factores; una eugenesia preventiva contemporánea se junta de manera complementaria con la aceptación de lo inevitable de la violación. El resultado de la esterilización es la ausencia del embarazo, pero también la ocultación y por lo tanto la perpetuación del abuso violento.

El dilema de la transparencia, como discurso social prevalente y como asunto legal que ha impactado algunas de las instituciones relevantes en el estudio citado, toma una forma particular cuando se considera dentro del marco de la relación entre abuso sexual y eugenesia. El abuso sexual real o potencial funciona de acuerdo con el concepto de verdad integrada previamente mencionado, como algo implícito y aceptado por debajo de la lógica superficial de la eugenesia. La falta de embarazo sirve como señal de transparencia a la vez que sostiene la doble violencia de abuso e impunidad. De esta manera una práctica eugenésica crea un espacio en el que el abuso se sigue dando, por debajo y por medio de un régimen de transparencia. Si el embarazo de la mujer con discapacidad tiende a significar abuso, al mismo tiempo significa un exceso de discapacidad. Quitar el riesgo contiene la discapacidad, pero también la redefine. Así, una discapacidad esterilizada funciona de manera transparente para contener y perpetuar (integrar) tanto la actividad sexual como la violencia sexual potenciales.

Podría parecer paradójico el hecho de que los procesos de esconder y devaluar la discapacidad, y de permitir la violencia sexual funcione de acuerdo con una cierta lógica de transparencia. A diferencia de los casos que enfatizan la transparencia de información sobre el uso de fondos públicos, aquí los trámites toman lugar alrededor y por medio de los cuerpos de mujeres con discapacidad, cuyo estado no embarazado puede llegar a significar disponibilidad sexual, violencia 
impune, y conformidad con expectativas eugenésicas-el cuerpo discapacitado transparente. El modelo de los derechos humanos sirve sin duda para revelar y explicar los abusos sistémicos de mujeres con discapacidad, pero revela a su vez sus propios límites, porque en este caso, es la corporalidad femenina, más que su pertenencia a la humanidad, la que sostiene la función de la transparencia. El cuerpo cumple el papel de encarnar información, de hacerla visible, como instrumento cuyos "derechos" quedan subeditados a su función de transmisor y suporte de comunicación.

En mayo de 2016, la Casa Hogar Esperanza, una institución de la Ciudad de México para "deficientes mentales," fue clausurada por autoridades municipales después de que investigaciones hechas por DRI, Colectivo Chuhcan, y la Comisión Nacional de Derechos Humanos revelaron la práctica institucional de esterilización forzada, y el argumento del personal de la Casa Hogar, de que esta práctica era necesaria para evitar embarazos en caso de violaciones cometidas por obreros que entraban a las instalaciones. Un reporte de transparencia de 2004, cumpliendo con la ley federal, mostró que la Casa Hogar Esperanza había recibido 36,000 pesos (aproximadamente \$3,200 USD) de la Secretaría de Salud (T.E.). Es gracias a la revelación de este trámite, requerido por la ley, que las prácticas de esterilización forzada entraron al discurso público de la transparencia, a pesar de la transparencia de la esterilización y violencia sexual integrada que comúnmente prevalece. Esta anécdota demuestra el éxito de los investigadores y activistas en señalar la injusticia en la cual se tiende a basar algunos servicios de salud pública. A la vez revela una compleja relación entre el concepto de la transparencia financiera inscrita en la ley federal, y las transparencias materiales y sociales de cuerpos, sexualidades, y vulnerabilidades.

Las nociones de transparencia y de inclusión exploradas hasta aquí en el ámbito legal y social, generalmente dependen de metáforas de lo visual como sentido privilegiado por el cual se recibe y se comprueba cualquier información. Al mismo tiempo, funcionan de acuerdo con un concepto de derechos humanos, que presupone un sujeto íntegro y activo, capaz de buscar, recibir y usar la información y otros recursos que solicita. Sin embargo, el énfasis en la discapacidad y en la materialidad del cuerpo como elemento central al proceso comunicativo sugiere desplazamientos potenciales entre sujetos y medios de información. Como se notó en el caso de la investigación sobre esterilización forzada y abuso sexual, las nociones de verdad, de violencia y de sujeto se ajustan cuando el mismo cuerpo cumple el papel de la transparencia como medio de información en carne viva. En la última sección de este ensayo, quisiera enfocarme en un texto literario en el cual la discapacidad se subraya de manera insistente, y también funciona como base de los procesos comunicativos, sus cualidades 
particulares y sus límites. Es decir, de manera similar a lo que ocurrió en el caso anteriormente discutido, aquí el dilema de la transparencia y de la inclusión se conjuga por medio y a través de la materialidad corporal de los personajes. De acuerdo con el concepto de lo intraactivo propuesto por Karen Barad (376), en la novela de Bellatin no existe necesariamente una separación anterior entre sujetos, o entre un sujeto y sus medios de comunicación. Esta materialidad por lo tanto implica una redefinición de zonas de contacto entre hechos, actores, y transmisión de información, o lo que determina los procesos y espacios posibles de transparencia e inclusión.

El autor mexicano-peruano Mario Bellatin ha abordado el tema de la discapacidad, y la ceguera en particular en varias de sus obras anteriores, y en este sentido habría que leer su novela breve, Carta sobre los ciegos para uso de los que ven, como parte de un corpus consistente, con hilos que continúan o se repiten, muchas veces dejando abierta la posibilidad de nuevas elaboraciones. ${ }^{?}$ Carta sobre los ciegos se narra desde la perspectiva de una mujer ciega y parcialmente sorda, que vive en comunicación constante con su hermano también ciego y sordo. La hermana tiene un implante coclear, que le permite oír hasta cierto punto y transmitir a su hermano lo que escucha por medio de un teclado adaptado. Los dos hermanos viven, siempre juntos, en un lugar denominado "Colonia de Alienados Etchepare," con otras personas con discapacidad. Es un sitio rodeado de perros salvajes, que frecuentemente atacan a los pacientes y a veces los matan; los perros son protegidos por grupos de defensa de los derechos de los animales. El lugar es, como nos dice, "una institución pensada originalmente solo para dementes" (11). Un escritor "fracasado" (12) y de un solo brazo (gesto frecuente en los textos de Bellatin), viene a la colonia a impartir un curso, cuyo propósito es crear un libro entre todos, y que todos aprendan así a escribir su propio libro. La novela avanza en el contexto de este curso, como reflejo parcial de la producción del libro colectivo, y de la comunicación continua entre los dos hermanos, pero sobre todo del monólogo de la hermana hacia su hermano, Isaías. Se cuenta también, por medio de la voz de la narradora, la historia de un barco atacado por piratas, que navega a la deriva, habitado por algunos sobrevivientes, incluyendo el cocinero y su amante, que son también los mismos hermanos. El monólogo incluye además la historia de cuando el profeta Mohammed mandó matar a muchos perros, por impuros, y prohibió la adoración de ídolos. Conviene ampliar aquí este hilo del relato, por

7 Por ejemplo, Bellatin reelabora elementos de obras suyas anteriores en sus novelas Disecado y El libro uruguayo de los muertos, entre otras. 
su resonancia a lo largo del texto. Los fedayines, dice la narradora, dependían de sus galgos para cacería y sobrevivencia en el desierto. Fueron a buscar a Mohammed, para preguntarle si efectivamente, tenían que matar y quemar a sus galgos. El profeta responde que el galgo no es perro, sino "un regalo de Aláh Todopoderoso." La narradora clarifica aquí, "Y un galgo sagrado, Isaías, no puede ser considerado sino un Lailajilalá" (37). Cabe notar que el galgo, como raza antigua de perro, conlleva la asociación de lo castizo, puro, y digno de protección especial.

El término Lailajilalá, que se repite a lo largo de la novela, viene cargado de significación, aunque nunca se ofrece un sentido definitivo de la palabra. Como la cita de arriba sugiere, el Lailajilalá abarca lo sagrado y específicamente lo que marca el borde entre lo más sagrado y lo más impuro, el galgo en su papel paradójico de ser y no ser perro, el dilema de la clasificación privilegiada. Se entera el lector que Lailajilalá es posiblemente el nombre del barco en el cual dice la narradora que navegan; y es la manera en que el padre de los hermanos llamaba a su hijo. Resulta ser el Lailajilalá el centro de los relatos que crean los estudiantes del curso, un personaje central. Afirma la voz del maestro que "según nosotros, el Lailajilalá parece querer convertirse en la Nada" (88). Para algunos de los estudiantes, el Lailajilalá se asocia con Cristo, representando un punto en uno de sus costados sangrantes, o se vincula con la creación del universo. El maestro del curso "habría querido, además, que el Lailajilalá los matara finalmente a todos" (77). Las discusiones en torno a este término funcionan en parte para subrayar la ambigüedad entre los personajes de los diversos relatos y los estudiantes del curso. De esta manera se desplaza el lugar del sujeto relevante a la historia, las distinciones entre lo impuro y lo sagrado, y entre las víctimas y los autores de la violencia.

En sus diversas variantes: en el barco, entre los perros y galgos del pasado lejano de Mohammed, entre los inquilinos, o pacientes de la colonia de alienados Etchepare, y en los relatos que escriben y cuentan, la narración enfatiza continuamente el peligro de la aniquilación, de muertes múltiples y atroces. Los perros que merodean la zona de la Colonia a veces matan a los pacientes; los mismos perros a su vez son protegidos por sociedades de ayuda animal; las ratas en el barco amenazan comer a los que quedan de la tripulación; y se escuchan balaceras fuera del salón en que se imparte la clase, pero que resultan tener lugar dentro de uno de los relatos escritos en el curso. En varios momentos, además, se sugiere como solución la destrucción total de la escena en su conjunto por medio del fuego: "la única salida sería prender fuego a la institución. Reducirla a cenizas" (35). Se crea así la equivalencia entre escenas de destrucción, entre el capitán que quema su barco, y Mohammed, que ordena las piras funerarias de 
cadáveres de perros: “Todos desaparecidos. Los perros salvajes, los dementes, el personal médico y administrativo, los internos del pabellón de los ciegos y sordos, el maestro que en este momento intenta ofrecernos un curso" (35). El fuego, como amenaza indiscriminada, terminaría con el problema de los perros que amenazan a los pacientes, pero en el mismo gesto, con los pacientes y todo a su alrededor, borrando finalmente la línea divisoria entre la amenaza y lo protegido, o lo impuro y lo sagrado.

Pero la amenaza, al parecer, no se cumple. Como concepto, marca la posible continuidad entre dentro y fuera, lo condenado y lo salvado, lo humano y lo animal, a la vez que el texto juega con la inversión de las oposiciones, como cuando sugiere la valorización de los perros a expensas de los habitantes humanos de la comunidad. El hecho de existir bajo la amenaza de la destrucción llega a ser lo que define al sujeto de cualidad excepcional, de Lailajilalá. El término se aplica con mayor insistencia al hermano ciego y sordo, Isaías, denominado "mi pequeño Lailajilalá" como conclusión de la novela; implícitamente, es a la vez el lector recipiente de este apodo, un sujeto que recibe toda la información por medio de una cadena de sentidos humanos y aparatos prostéticos, pero que posiblemente no existe.

El Lailajilalá, aún sin definición precisa, marca la división entre planos de existencia, entre la realidad y la ficción, lo interno y lo externo a los relatos creados, así como el fuego que podría acabar con todo. El concepto empleado por Bellatin aquí se asemeja a otros más familiares en la crítica - el chivo expiatorio, el ser abyecto, el homo sacer- y, a la vez, cumple una función ya reconocible desde obras anteriores del mismo autor. La distinción del término radica en su inscripción en un lenguaje que no pretende traducirse, ni revelar sus orígenes lingüísticos. El Lailajílala no existe simplemente como término para explicar un fenómeno en el contexto de la novela, sino que marca un límite de comunicación. Es la palabra en sí, en la novela y en los diversos relatos creados por los personajes dentro de ella, y la materialidad de esta palabra, la que ocupa una posición límite, entre salvarse o destruirse, formar parte de un todo, o separarse, entender o quedar fuera de todos los lenguajes.

En Carta sobre los ciegos, el dilema de la inclusión-transparencia adquiere su materialidad por medio de los mecanismos de comunicación y lenguaje. Se insiste a lo largo de la narración en el aparato comunicativo que sirve de vínculo práctico entre los hermanos, una computadora conectada a un aparato electrónico de Braille. La escritura en el aparato sirve de lazo a su vez entre los hermanos y el mundo, dándole forma narrada a lo oído y sentido. La voz narrativa de la hermana rechaza la idea de que por ser ciegos y sordos pertenecen a una realidad aparte. De manera similar, el curso de escritura vincula a los hermanos y demás 
personajes al mundo externo, pero por medio de una mentira conveniente. La narradora explica la función práctica del curso de la siguiente manera:

[...] recibimos esta serie de cursos ante la posibilidad de que alguien ajeno a la Colonia de Alienados Etchepare indague sobre nuestra permanencia en lugar semejante. Les comunican a los de afuera, Isaías - si por casualidad alguien preguntara por nosotrosque no somos internos; que nuestra presencia en este lugar no rompe con ningún estatuto pues somos un grupo de necesitados que acudimos a las instalaciones sólo a recibir, por unas horas, los cursos que nos ofrecen, para volver luego a nuestras casas. (44-45)

En realidad, como se menciona varias veces en el texto, los hermanos y otros estudiantes del curso son "recluidos" en la Colonia, en un espacio delimitado por los perros salvajes y barreras de metal. Esta insistencia repetitiva en el hecho de estar recluidos parece darle al lugar el papel de una institución psiquiátrica, cárcel, u otro espacio en el que los residentes permanecen en contra de su propia voluntad. La reclusión de personas con discapacidad en instituciones, y a veces en contra de su voluntad individual, es frecuente en el contexto mexicano, como lo es en otros países, y representa un grave desajuste entre la apariencia legislativa y la práctica.

En la novela, el curso de escritura y los relatos que se producen como resultado aparecen, entonces, como pretexto para justificar la presencia de personas con discapacidad en la Colonia y para ofuscar el hecho de que vivan allí recluidos de manera permanente y bajo la amenaza de la violencia. Los cursos operan de manera "transparente," revelando la existencia del espacio y sus habitantes, a la vez que crean la impresión de legitimidad, del paso libre entre fuera y dentro. Al mismo tiempo, el curso y la escritura, como gestos de comunicación, funcionan para mantener encerrados a los pacientes, igual como la transparencia o hipervisibilización de la ley permite y sostiene varios abusos. Sin embargo, la novela de Bellatin y la revelación pasajera de una reclusión posiblemente ilícita que logra disfrazarse gracias a un curso de escritura no pretende denunciar estas prácticas, ya que el texto no obedece a la estructura de una denuncia. Más bien resalta la complejidad del papel de la escritura y de los cuerpos, como hechos materiales y como proceso encadenado a las barreras y puentes que pone en marcha. El vínculo prostético entre los hermanos, animado por la escritura del texto, funciona también para revelar y ofuscar una relación sexual entre ellos, y la ambigüedad de género de la hermana. Explica la narradora: "Ya te lo he dicho varias veces, Isaías: nosotros no deberíamos encontrarnos habitando estas instalaciones. Ni tampoco estar acostados con mi pene en tu garganta, en este agujero que descubrimos en el casco del barco" (38). Tanto la institucionalización ilícita como la relación incestuosa forman parte de un proceso de escritura, recalcando de 
esta manera la interdependencia entre la comunicación corporal y prostética y la transparencia relativa de los espacios regidos por la ley.

Como modelo comunicativo, la creación del relato basado en monólogo pretende llegar a su interlocutor, aunque al mismo tiempo recalca la sospecha de que las palabras no lleguen a ningún lado. En este sentido, la línea divisoria de reclusión entre el espacio de la Colonia y el mundo exterior, entre lo sagrado-impuro y lo cotidiano, representa y repite la separación ambigua e inherente al acto de escribir. Se refiere aquí a una forma y proceso de escritura particular, en la que se enfatiza la traducción material y sensorial, como cuando en palabras de Diderot, citadas en el epígrafe de la novela de Bellatin, un ciego explica lo que es un espejo, pero en términos de tacto, de relieve. Se trata de una máquina, que "pone las cosas de relieve, lejos de sí mismos."

La referencia a Diderot es significativa aquí, porque vincula el texto de Bellatin explícitamente a una obra del mismo título que tuvo un impacto notable en el pensamiento sobre la ceguera y el conocimiento humano, a partir de su publicación en 1749. La novela de Bellatin enfatiza sobre todo el lugar de la escritura por medio del cuerpo humano y sus prótesis, como mecanismo de una transparencia siempre imperfecta, cuyo mensaje quizás no llega a su interlocutor. En cambio, el tratado de Diderot se enfoca en los límites del conocimiento humano, por medio de un análisis de los sentidos, particularmente la vista y el tacto, con el propósito de desmentir la filosofía cartesiana a favor del pensamiento empírico. El texto del filósofo francés provoca su propio escándalo, debido a una escena ficticia en el texto, en que el matemático ciego, Saunderson, niega la existencia de Dios, y que tuvo como resultado el encarcelamiento de Diderot en Vincennes durante tres meses (Rutler 174). El peligro ideológico a que se enfrenta Diderot no depende de su uso de la discapacidad como tema del texto, pero es curiosa la conjugación de discapacidad y conocimiento filosófico en su obra, y la manera en que la ceguera termina por ilustrar no solamente lo que un sujeto dado puede saber, y cómo accede al conocimiento, sino además un sistema imperfecto de metáforas que organiza las relaciones entre diversos sentidos, y entre el universo y las formas de conocimiento humano. ${ }^{8}$

8 En el texto se presenta el debate filosófico sobre un ciego de nacimiento que adquiere la vista después de una operación; se pregunta si esta persona, que anteriormente conocía los objetos por medio del tacto, podría reconocer una esfera y un cubo por la vista. El dilema fue elaborado originalmente por William Molyneux y discutido por Locke en su Ensayo sobre el entendimiento humano, de 1689 (Diderot 109). Aunque Diderot no ofrece una respuesta definitiva a la pregunta, la discusión sirve para considerar hasta 
El texto de Bellatin recalca a su manera el escándalo posible del lugar sagrado siempre en el borde de la impureza, que es a su vez el lugar de lo que pretende transmitir la escritura, entre cuerpos y sistemas de comunicación diversos. Aunque se trata de escándalos y riesgos distintos, tanto en el texto de Diderot como en el de Bellatin, el problema del conocimiento gira en torno a métodos de significación y procesos sensoriales que traducen materialmente un sentido, sin la garantía de que la información cruce la frontera para llegar a su recipiente. En este sentido, el escándalo de lo que no podemos saber, en Diderot, arraigado en la divergencia de modos de percepción, se convierte, en el texto de Bellatin, en un escándalo de comunicación - de transparencia imposible- que abre o cierra los límites entre un mundo y otro, de esta manera revelando los contactos y discontinuidades entre lo sagrado y lo impuro, o entre el cuerpo y su mensaje.

La novela de Bellatin en su diálogo parcial con el tratado clásico de Diderot, y en su ubicación ambivalente entre curso de escritura, relato de institucionalización, y traducción imposible de un lenguaje prostético-corporal, complica a su manera las nociones de transparencia y de inclusión que se han considerado a lo largo del presente texto. En el ámbito legal, regido por un discurso de derechos humanos, se tiende a considerar la transparencia y la inclusión como proyectos realizables de manera definida. Según esta visión, la transparencia y el acceso a la información se entienden de acuerdo con una dicotomía de "informante-informado" (Cortés Ontiveros 17), y por lo tanto son conceptos que obedecen a un lenguaje preestablecido; con tal de ser suficientemente claros, este lenguaje y los datos que alberga serán universalmente accesibles. Sin embargo, el caso particular de abuso sexual y esterilización forzada discutido anteriormente demuestra que la corporalidad de la información y la relación entre la violencia y el régimen de la transparencia alteran el mecanismo de comunicación; por eso, ciertos hechos no se transmiten, o no se registran como hechos. El texto de Bellatin plantea a su vez una forma de discapacidad como experiencia corporal que define el proceso de la escritura y de las zonas de contacto entre diversos cuerpos y espacios. En esta lectura, en lugar de proponer la inclusión de personas con discapacidad, o la revelación completa de los hechos ofuscados de abuso y exclusión, la narración se materializa por medio del cuerpo con discapacidad y su comunicación prostética. De esta manera, el texto pone en movimiento constante lo intraducible, y nos obliga a repensar los mecanismos corporales de la comunicación, en otros términos, la permanencia dinámica de la discapacidad en el mundo.

qué punto la información captada por un sentido o sistema sea transferible a otro, y si existe un vínculo necesario entre los diferentes modos de percepción. 


\section{Bibliografía}

Barad, Karen. 2007. Meeting the Universe Halfway: Quantum Physics and the Entanglement of Matter and Meaning, Durham and London: Duke University Press.

Bellatin, Mario. 2011. Disecado, Madrid: Sexto Piso.

Bellatin, Mario. 2012. El libro uruguayo de los muertos, Madrid: Sexto Piso.

Bellatin, Mario. 2017. Carta para los ciegos para uso de los queven, México: Penguin Random House.

Cortés Ontiveros, Ricardo. 2005. "La transparencia en México: razón, origen y consecuencias", en: Revista de la facultad de derecho en México 244: 11-31.

Diderot, Denis. 1972. Supplément au voyage de Bougainville. Pensées philosophiques. Lettre sur les aveugles, Paris: Garnier-Flammarion.

Escobedo Romero, Juan/Rivera Aguilera, Luis Roberto. 2012. "Las políticas de información: antecedentes internacionales y situación actual en México", en: Revista legislativa de estudios sociales y de opinión pública 15 (10): 41-65.

Instituto de Transparencia, Acceso a la Información Pública, Protección de Datos Personales y Rendición de Cuentas de la Ciudad de México, http:// www.infodf.org.mx/ [15 de marzo 2019].

Rancière, Jacques. 2011. Política de la literatura. Trans. Marcelo G. Burello/LucíaVogelfang /J.L. Caputo, Buenos Aires: Zorzal.

Robles, Johana. "Cambian nombres a estaciones de metro Etiopía y Víveros", en: El Universal, 26 de marzo 2009, http://archivo.eluniversal.com.mx/ notas/586753.html [15 de marzo 2019].

Rodríguez, Priscilla. 2015. Abuso y negación de derechos sexuales y reproductivos a mujeres con discapacidad psicosocial en México, México: Disability Rights International y Colectivo Chuhcan.

Román Echeverrí, Carlos Gustavo. 2011. "Espejos: transparencia, reflejo, contradicción e interacción", en: Cuadernos de Música, Artes Visuales y Artes Escénicas 6 (1): 65-80.

Rosenthal, Eric/Jehn, Erin/Galván Sofía. 2010. Abandonados y desaparecidos: segregación y abuso de niños y adultos con discapacidad en México, México: Disability Rights International y Comisión Mexicana de Defensa y Promoción de los Derechos Humanos.

Rutler, Tracy L. 2018. "Prosthetic Matters: On Blindness, Machines and Knowledge in Diderot's Letter on the Blind", en: Criticism 60 (2): 171-193.

Salazar Rebolledo, Grisel. 2013. "Comentario a la propuesta de reforma constitucional en materia de transparencia aprobada en 2012 por el senado", en: Boletín Mexicano de Derecho Comparado 138: 1169-1185. 
Saúl, Lilia. "Fox: Ley de transparencia, logro sexenal", en: El Universal. Domingo 3 de julio de 2005, http://archivo.eluniversal.com.mx/nacion/126823.html [15 de marzo 2019].

Secretaría de Gobernación. "Programa Nacional para el Desarrollo y la Inclusión de las Personas con Discapacidad 2014-2018”, http://www.dof.gob.mx/nota_ detalle.php? codigo $=5343100 \&$ fecha $=30 / 04 / 2014$ [15 de marzo 2019].

T.E. El diario de la tercera edad. "La Casa Hogar 'Esperanza' fue denunciada por esterilizar mujeres con discapacidad mental." (8 de mayo 2016), http:// diariote. $\mathrm{mx} / \mathrm{p} \mathrm{p}=11588$ [15 de marzo 2019].

Valencia, Sayak. 2016. Capitalismo Gore: Control económica, violencia y narcopoder, México: Paidós.

Zavala, Oswaldo. 2018. Los cárteles no existen: Narcotráfico y cultura en México, México: Malpaso. 



\title{
De la inocencia a la rebelión. Diversidad funcional y la esperanza de una historia alternativa: Marianela (1878) de Benito Pérez Galdós y Los santos inocentes (1981) de Miguel Delibes
}

\begin{abstract}
This article proposes an interpretation from the perspective of disability studies of two Spanish novels, Marianela (1878) by Benito Pérez Galdós and Los santos inocentes (1981) by Miguel Delibes. Despite its melodramatic tones and an apparently compassionate representation of disability, Galdós uses blindness and physical deformity as means to criticize bourgeois morality and conventions, putting into question notions such as Christian charity and positivist modernity. On the other hand, Miguel Delibes recreates two severely disabled characters, both physically and cognitive, to symbolize social rebellion against the almost dictatorial system still existing in Castilian rural life during Franco's era.
\end{abstract}

Keywords: pobreza, crítica social, deformidad, discapacidad, novela realista española

\section{Introducción}

Ciegos, sordos, inválidos, personas con diversos síndromes y deformaciones congénitas han sido protagonistas inolvidables en la literatura, la pintura y el cine en lengua española. Como personajes literarios, frecuentemente nos hemos ocupado de ellos como figuras alegóricas o como metáforas. Si bien la teoría postestructuralista, particularmente Michel Foucault, se había ocupado de la construcción de un discurso de la "anormalidad” psicológica y fisiológica en la década de los setenta ${ }^{1}$, hasta finales del siglo veinte, con la aparición de estudios pioneros como el de Garland-Thomson ${ }^{2}$, se había reflexionado muy poco sobre la diversidad funcional en el ámbito literario. En el análisis de los relatos sobre la discapacidad, aquellos más positivos sobre esta cuentan historias de la recuperación de una persona discapacitada, la instrumentalizan moralmente para

1 Además de sus conocidos ensayos sobre la locura y la psiquiatría, véase en particular Les Anormaux. 1999. Cours au Collège de France 1974-1975, Paris: Gallimard.

2 Véase Garland-Thomson, Rosemarie. 1997. Extraordinary bodies. Figuring physical disability in American culture and literature, New York: New York University Press. 
beneficio de los física y cognitivamente normales o relatan el fracaso de una persona con discapacidad al enfrentarse con el cruel mundo de la normalidad (Hartwig 2018: 9). Frecuentemente, los autores no discapacitados inventan protagonistas con discapacidad para crear una mirada externa de aquella normalidad a la que ellos mismos pertenecen (Mürner 1990: 203), para acceder así a un punto de vista alternativo que les permite salir de sí mismos, lo que sin embargo no implica una emancipación o normalización de la discapacidad que permitiese cambiar nuestra percepción de ella. Pensarla habría de responder a la necesidad de normalizar las figuras discapacitadas y arrancarlas de su marginalidad sin pasarlas por la rasa tábula de la asimilación. Nuestro artículo propone pensar su relación con el resto de la sociedad, una que pueda ser no solo cultural, sino también política y social: si bien esto es difícil partiendo desde textos literarios escritos por autores sin discapacidades, sin estar completamente libres de los tópicos comunes identificados por Hartwig (2018: 9), la literatura puede proponernos una representación de la discapacidad o diversidad funcional que nos permita explorar su potencial de sacarle la vuelta a las convenciones sociales y alterar el orden establecido en el mundo de los "cuerpos normados". Desde su posición, los personajes con diversidad funcional pueden poner en jaque las jerarquías sociales y servir de pretexto para ejercer una crítica social o política. Si bien muchas de las grandes narrativas les limitan a un papel moralizante, existen también ejemplos literarios que les permiten abandonar su rol pasivo para emanciparse, transformar y transgredir (si no es que también agredir) el status quo. Para ilustrar esta tesis voy a recurrir a dos novelas españolas: Marianela (1878), de Benito Pérez Galdós, y Los santos inocentes (1981) de Miguel Delibes. Publicadas con una distancia de aproximadamente cien años, en común tienen el retrato de sociedades rurales altamente jerárquicas donde la discapacidad tiene un papel fundamental para la reversión de dicho orden.

\section{La deformidad y la ceguera. Marianela (1878) de Benito Pérez Galdós, ¿ diversidad funcional como emancipación?}

Benito Pérez Galdós publica en el año 1878 su novela Marianela con rasgos muy marcados del naturalismo. Inspirado en un tratado de medicina francés sobre la curación de un caso de ceguera congénita (Casalduero 1984: 21), Galdós cuenta la historia de Pablo Penáguilas, ciego de nacimiento, hijo de un rico agricultor, y su lazarillo, Marianela, una adolescente que vive descalza y sin posesión alguna deambulando por las minas de Socartes, al norte de España. De esta novela, se ha comentado ya ampliamente el aspecto filosófico y simbólico de la ceguera (p. ej. Ruiz 1970, Casalduero 1984, Alvarado Vega 2008, Anderson 2015), pero 
poco desde ha comentado desde una perspectiva de los estudios sobre la diversidad funcional y su dimensión social. Pablo y Marianela representan dos polos extremos de una sociedad rural en pleno proceso de transformación industrial. Entre ambos surge un amor romántico a pesar de las enormes diferencias que los separan: mientras Pablo era heredero de un próspero agricultor, Marianela era huérfana de un padre golpeador y una madre alcohólica que, tras abandonarla, se suicidó en un rapto de desesperación. Pablo gozaba de una gran inteligencia y cultura, cultivada por la lectura en voz alta de su dedicado padre. Marianela, por su parte, vivía arrinconada como un objeto en la vivienda de los capataces, y apenas poseía las nociones más básicas del mundo, regida por una religiosidad más intuitiva que dogmática. El rico joven ciego era bello como "una estatua griega" a sus veinte años. Marianela, desproporcionada y fea, a sus 16 años parecía físicamente de doce, atrapada en un cuerpo deteriorado por la miseria y la desnutrición, descrita con compasión como "atrasadilla" y como un "monstruo" deforme. Unidos en un romance juvenil, Pablo ignora completamente que está enamorado de una chica fea y deforme: gran ironía ser poseedor de una belleza imposible de contemplar por sí mismo, mientras la Nela, provista de todos sus sentidos, era plenamente consciente de su fealdad. La ceguera física de Pablo y la ceguera espiritual (ignorancia) de la Nela es el terreno común en el que ambos coinciden durante sus caminatas en la soledad del campo, espacio de libertad donde las jerarquías sociales del pueblo desaparecen. Las diferencias entre ambos personajes son aún así latentes: Pablo tiene una educación más amplia, y ama pacientemente a Marianela como a un ser débil al que tiene la labor de "domesticar", rasgo evidentemente acuñado bajo la influencia en Galdós del positivismo de Comte (Casalduero 1984: 34): "Tu imaginación te hace creer mil errores. Poco a poco yo los iré destruyendo, y tendrás ideas buenas sobre todas las cosas de este mundo y del otro." (Galdós 1984: 99). Mientras Pablo pretende guiar a Marianela por las sendas del conocimiento, Marianela lo lleva a él de la mano a través de las tinieblas del mundo: él permanece inconsciente de su fealdad y la imagina bella; a pesar de que nunca ha gozado del sentido de la vista, posee una noción intrínseca, aunque "errónea" (Ruiz 1970: 872) de lo bello. Pablo tiene un intelecto más agudo, mientras la Nela no tiene el desarrollo intelectual que corresponde a su edad: "-Atrasadilla está. ¡Qué desgracia! [...] Y yo me pregunto: ¿para qué permite Dios que tales criaturas vivan?..." (Galdós 1984: 126). Movido por el amor y la simpatía, Pablo asume su labor didáctica: “Tu imaginación te hace creer mil errores. Poco a poco yo los iré destruyendo, y tendrás ideas buenas sobre todas las cosas de este mundo y del otro." (Galdós 1984: 99). Dentro de este binomio entre sabio e ignorante, civilizador e incivilizado, rico y pobre, a Pablo, sin embargo, lo 
mueve un deseo sublimado en un amor expresado en su lenguaje hiperbólico y en las sutiles alusiones al contacto físico y su agitación:

Sí, tú eres la belleza más acabada que puede imaginarse - añadió Pablo con calor-. ¿Cómo podría suceder que tu bondad, tu inocencia, tu candor, tu gracia, tu imaginación, tu alma celestial y cariñosa, que ha sido capaz de alegrar mis tristes días; cómo podría suceder, cómo, que no estuviese representada en la misma hermosura?...Nela, Nela -añadió, balbuciente y con afán-¿No es verdad que eres muy bonita? (Galdós 1984: 106)

Sin embargo, el amoroso trato de Pablo se enfrenta a las palabras de su padre, quien insiste en la fealdad de la Nela ante la negación enfática de su hijo. En escena aparece el doctor Teodoro Golfín, quien se ha ofrecido a operar aquella ceguera: el padre, deseoso de corregir este "error" físico de su hijo para así permitirle "ver la verdad", se apresura a organizar la futura boda con la prima Florentina, misma que habría de realizarse tras la operación. Pablo había heredado una rica fortuna de un tío recién muerto, lo que le permitiría continuar con las expectativas de una vida burguesa al lado de una mujer estrictamente criada. Galdós utiliza la ceguera para reflexionar sobre las circunstancias sociales: en particular sobre la burguesía rural española, presta hacia el progreso material (simbolizada en las minas), la acumulación de riqueza (la herencia recibida), lo conveniente y convencional (el matrimonio con Florentina), opuestas sin embargo al romanticismo del amor ciego y juvenil entre Pablo y Nela, simbolizado en sus largos paseos por la naturaleza. En el marco de aquella constelación positivista que representa el doctor Teodoro Golfín y el padre de Pablo (Francisco Penáguilas), la ausencia de la vista es un error a corregir para que Pablo se reintegre a la alta sociedad, administre su fortuna y se case. Continuar ciego es continuar en el error: su amor por Marianela, nacido de una ilusión, lo aleja de las expectativas que su padre tiene para él. La representación de la diversidad funcional pone en evidencia estas rígidas convenciones sociales, de las que Pablo no parece consciente, así como tampoco lo es de su propia belleza ni de la fealdad de la Nela.

Por su parte, Marianela no tiene una discapacidad física congénita como la de Pablo; sin embargo; sabemos de su cuerpo mal desarrollado, atrofiado, también sobre su fealdad, y de su supuesto retraso intelectual, agravado por la pobreza extrema: hay una delicada línea entre la diversidad funcional o la insistencia social en patologizar a un ser humano que, por ser distinto y marginal, es convertido o construido discursivamente como discapacitado. La fealdad de Marianela "es la encarnación de [...] una sociedad deforme, cruel, que no se apiada de los débiles" (Farrag 2011: 141). El doctor Teodoro Golfín tiene una aproximación 
paternal, pedagógica, hacia Marianela. Si bien representa la ciencia y el progreso material (Andrews 2015: 912), Golfín también tiene una dimensión moral que podemos observar en sus intervenciones paternalistas por proteger y educar a la Nela. Pero su función protectora y correctiva es también casi antropológica: "Se halla en la situación de los pueblos primitivos-afirmó Teodoro-. Está en la época del pastoreo" (p. 127). El doctor Golfín reproduce en Marianela el arquetipo del "buen salvaje" de la literatura colonial del siglo dieciocho, petrificado en un estado de eterna infancia, incapacitado para el lenguaje y asexuado, apenas encontrando refugio en una comprensión tardía y primitiva de las ideas religiosas $^{3}$. Las palabras de Golfín recuerdan aquella práctica, frecuente en todo el siglo diecinueve y partes del veinte, de clasificar a aquellas "razas" y "pueblos" preindustriales, no europeos, en mapas taxonómicos, llegando al extremo de exhibir a múltiples personas como "ejemplares exóticos" en circos y zoológicos en Europa y Norteamérica ${ }^{4}$.

La deformidad física de Marianela es una metáfora de su relación con el mundo circundante: su cuerpo y cognición están desfasados respecto a la normalidad, pero también con respecto al progreso de los nuevos tiempos; mientras la Humanidad se perfecciona material e intelectualmente en el transcurso de la Historia, ella se queda atrás en un estado primitivo que, al mismo tiempo, está construido discursivamente ("atrasadilla", "fea", "deforme") como una discapacidad intrínseca, y no así como una consecuencia de factores extrínsecos como la pobreza. Pablo, que había deseado sacar a Marianela de su estado, al recuperar la vista se enamora casi inmediatamente de Florentina, de una belleza "real", frente a la belleza "imaginada", pero inexistente de la Nela: la visión "se convierte en el signo de una verdad que está más allá de su control [de Pablo]" (Alvarado Vega 2008: 125). Arrebatado por el deseo, sublimado en un lenguaje hiperbólico que parece incluso irreal al resto de los personajes (Borrallo Solís 2016: 12), Pablo olvida el cariño hacia su antigua amiga y lo conduce hacia Florentina:

¡Prima..., por Dios!-exclamó Pablo con entusiasmo candoroso-, ¿por qué eres tan bonita?... Mi padre es muy razonable..., nada puede oponerse a su lógica ni a su bondad... Florentina, yo creí que no podía quererte: creí posible querer a otra más que a ti...¡Qué necedad! Gracias a Dios que hay lógica en mis afectos... Mi padre, a quien he

3 Un ejemplo de dicho arquetipo puede encontrarse en textos, por ejemplo, como el de Marie-Catherine Hacquet, atribuido a Charles Marie de La Condamine, titulado Histoire d'une jeune fille sauvage (París, 1755).

4 Véase: Bancel, Nicolas (ed.). 2004. Zoos humains. Au temps des exhibitions humaines, Paris: La Découverte. 
confesado mis errores, me ha dicho que yo amaba a un monstruo... Ahora puedo decir que idolatro a un ángel. (p. 221)

Recuperar la vista significa también recuperar una visión "correcta" de las cosas: la opinión de su padre, "muy razonable", es también "lógica" y "bondadosa", otorgándole no solo una cualidad objetiva, sino también moral. Los sentimientos que surgieron dentro de la oscuridad de la ceguera son, por lo tanto, "errores" de los cuales Pablo se ha redimido para "idolatrar" ahora a un ángel, opuesto al "monstruo" paupérrimo que amaba. Aunque a primera mano Pablo había desafiado con firmeza las expectativas que correspondían a un joven de su condición, atractivo y rico, Galdós no reivindica su discapacidad: la ceguera podía y debía corregirse para regresar al personaje al camino de la razón, la lógica y la bondad moral, anteriormente atrapado en un mundo de un deseo irracional e ilusorio. A partir de esto, se ha interpretado la ceguera de Pablo desde un enfoque platónico en el que la metáfora luz-oscuridad explica cómo aquel puede entender el mundo a partir de una conciencia esencial, incapaz, sin embargo, de entender en su plenitud el mundo exterior y su propia identidad humana (Ruiz 1970: 872); por otra parte, la curación de la ceguera se ha leído como una doble transición hacia una vida nueva, donde sin embargo la incapacidad física de mirar implica la muerte simbólica de su capacidad de mirar al interior del espíritu (Alvarado Vega 2008: 118; y Gonzálvez 2006: 142). Al recuperar la vista, las cualidades morales de Marianela ya no son dignas de ser apreciadas ni amadas: se vuelven invisibles, y la belleza que Pablo encontraba en ella desaparece también para convertirla en un "monstruo":

Pablo alargó una mano hasta tocar aquella cabeza, en la cual veía la expresión más triste de la miseria y de la desgracia humanas. Entonces la Nela movió los ojos y los fijó en su mano. Creyóse Pablo mirado desde el fondo de un sepulcro; tanta era la tristeza y el dolor que en aquella mirada había. Después la Nela sacó de entre las mantas una mano flaca, morena y áspera, y tomó la mano del señorito de Penáguilas, quien, al sentir su contacto, se estremeció de pies a cabeza y lanzó un grito en que toda su alma gritaba. (Galdós 1984: 223)

Como se observa en este pasaje, dicha transición sucede no gracias a la vista, sino a la unión de ambas manos. El tacto y el oído habían sido el medio principal de contacto entre ambos jóvenes, que solían pasear juntos asidos del brazo en el bosque: pero por las sensaciones táctiles que Pablo recupera la identidad de Nela. El sentido de la vista domina los primeros instantes de este encuentro y, paradójicamente, es la vista quien primero lo engaña pues cree tener ante sí a una pobre e "infeliz muchacha" (Galdós 1984: 222): no es sino a través del contacto de ambas manos que descubre su "error"; la ilusión choca fuertemente con la 
nueva realidad construida bajo su recuperada vista y la influencia de su "razonable" padre. La visión es la verdad racional del positivismo, mientras que la ceguera es el mundo romántico de las ilusiones. Como lo observan algunos críticos, Marianela es una exploración alegórica de lo que el positivismo comtiano implica: un sacrificio del mundo bucólico del romanticismo en pos del progreso de la industria y la ciencia (Anderson 2015: 921), idea que puede reforzarse en la yuxtaposición constante entre elementos románticos y realistas a lo largo de la novela (Borrallo-Solís 2016: 15). El descubrimiento del verdadero aspecto físico de Marianela es decididamente simbólico de esta transición; la dulzura del espíritu romántico, simbolizado en las caminatas en el campo, desaparece en la amarga crueldad de los nuevos tiempos: la fealdad de la miseria y sus marginales habitantes.

Pero estas y otras interpretaciones sobre la ceguera de Pablo se limitan a su dimensión filosófica, dejando atrás la posición social del personaje discapacitado: la idea galdosiana de la ceguera encuadra dentro de una categoría dicotómica entre enfermedad e identidad (Hartwig 2017: 11), donde la "verdadera" esencia del personaje, es decir, la vida que le corresponde en la aristocracia rural, se encuentra entorpecida por dicho mal congénito: la operación quirúrgica habría de permitirle continuar con el proyecto de progreso material y ascenso económico que simbolizan su propio padre, Francisco Penáguilas, Carlos Golfín, ingeniero de minas, y Teodoro Golfín, oftalmólogo, en los que Anderson encuentra una evidente constelación comtiana (Anderson 2015: 912), pero en los que también podemos encontrar cabales representantes de los nuevos valores de una burguesía que avanza de lo rural a lo industrial.

Por una parte, en la figura de Pablo no hay una reivindicación de la ceguera: es una alegoría sobre la crueldad de un mundo en transición hacia una modernidad donde todo aquello que estorbe el progreso (la ceguera, en este caso) debe eliminarse. En esta lógica, Marianela forma también parte de aquella categoría de lo que se debe redimir. Sin embargo, aunque débil y huérfana, se resiste. Regresemos a la historia: la bella prima Florentina, próxima esposa de Pablo, se compadece profundamente de Marianela y decide convertirse en una madre y hermana para ella; le enseñaría lo que ella sabía, la alimentaría y la vestiría. Si bien la despojaría del amor, la proveería de lo que nunca tuvo en la vida: en otras palabras, la "normaría", eso sin necesariamente liberarla de la celda que le estaba asignada en la jerarquía social. Le dice Pablo a la Nela, antes de reconocerla:

- ¡Ah! - dijo Pablo—, supe por mi tío que Florentina había recogido a una pobre... ¡Qué admirable bondad!... Y tú, infeliz muchacha, alégrate, has caído en manos de un ángel...¿Estás enferma? En mi casa no te faltará nada...Mi prima es la imagen más hermosa de Dios... (Galdós 1984: 222) 
Sometida a una mirada clínica que convierte en patología su pobreza, esta mirada también pretende "sanarla", es decir, someterla a la caridad cristiana de Florentina, "un ángel", la "imagen más hermosa de Dios". Marianela se veía obligada ahora a observar en total sumisión la pérdida de su amor y a aceptar sin reniego alguno su inferioridad. Habiendo inicialmente rechazado aquellas providencias, Golfín la convence de aceptar aquellos generosos ofrecimientos: “ $¡ Q u e ́$ mal juzgas su caridad! Hay seres tan infelices que prefieren la vida vagabunda y miserable a la dignidad que poseen las personas de un orden superior” (Galdós 1984: 195). Al explicarle por qué era imposible que su amor con Pablo se realizara, el médico Golfín explica paternalmente a Marianela: "Aprenderás a poner tu fealdad a los pies de la hermosura, a contemplar con serenidad y alegría los triunfos ajenos, a cargar de cadenas ese gran corazón tuyo, sometiéndolo por completo, para que jamás vuelva a sentir envidia ni despecho, para que ame a todos por igual, poniendo por encima de todos a los que te han hecho daño" (Galdós 1984: 200). La caridad se convierte en un acto de sometimiento: de la Nela se espera un absoluto dominio de sus pasiones, pues, aparentemente, una persona como ella no tenía más remedio que someterse a aquellas personas "de orden superior" para permitirles cumplir con su misión cristiana. Marianela, más que un fin, se convertía así en un medio. Sin embargo, el precio que debía pagar era muy alto: mientras Florentina se lleva al bello Pablo, la Nela debía aceptar la condena de guardar silencio a cambio de su redención social. Sin tener conciencia de que Marianela estaba presente, Pablo dice a su prima Florentina: "mi padre me ha dicho que estuve enamorado de un monstruo" (Galdós 1984: 221). Al escuchar estas palabras, la Nela, profundamente dolida, muere. A pesar de los intentos por reanimarla, se niega a vivir. Mientras Pablo calla, Teodoro Golfín y Florentina contemplan angustiados el advenimiento de su muerte, y como si descubriera en la intervención quirúrgica un profundo error, el médico exclama: “¡Todo por unos ojos que se abren a la luz... a la realidad!... No puedo apartar esta palabra de mi mente." (Galdós 1984: 227). Lo que la ciencia pudo hacer con Pablo, no lo logra con Marianela, y de pronto, se muestra la otra cara del prometedor progreso: la muerte. Al morir, la Nela apenas pronuncia palabra:

—Sus labios se mueven — gritó Florentina.

- Habla.

Sí, los labios de la Nela se movieron. Había articulado una, dos, tres palabras.

- ¿Qué ha dicho?

- ¿Qué ha dicho?

Ninguno de los dos pudo comprenderlo. Era, sin duda, el idioma con que se entienden los que viven la vida infinita. Después, sus labios no se movieron más. (Galdós 1984: 228) 
Por una parte, esta visión final de una Nela que muere de amor corresponde a la opinión de la crítica feminista, misma que observa en las novelas de Galdós el predominio de un "victimismo angélico" en la construcción de los personajes femeninos, donde estos son "suaves, susceptibles y maleables, tanto física como emocionalmente". ${ }^{5}$ Pero por otra parte, la muerte de Nela también representa un acto de resistencia ante las estructuras burguesas que pretenden "rescatarla", uno que sucede a través del lenguaje: del silencio y de la imposibilidad de ser entendida. Si antes Golfín quiso domesticarla a través del diálogo, el silencio que guarda Nela en sus momentos finales y su incomprensible balbuceo es la negación de los acuerdos alcanzados. La sublevación de Marianela está en la inteligibilidad de la palabra: primero se niega a responder, y después no puede ser entendida. Hablaba, sin duda, otra lengua, "el idioma con que se entienden los que viven la vida infinita" (Galdós 1984: 228). Así el plan de piedad católica fracasa rotundamente, del mismo modo que la ciencia y el discurso positivista. Pero con su muerte, Marianela frustra también el plan de perfeccionamiento moral de Florentina, Golfín y los Penáguila, ante el cual Galdós es bastante crítico: en el capítulo final “¡Adiós!”, el autor describe las vistosas pompas fúnebres en honor a la Nela y el elegante sepulcro de mármol en que fue sepultada como la manera que tenía la señorita Florentina de "atenuar la pena de no haber podido socorrer en vida a la Nela” (Galdós 1984: 229-230). Después de ello, introduce algunos pasajes del presunto relato de "unos extranjeros [ingleses] de esos que se llaman turistas", Sketches from Cantabria, donde se describe el "espléndido sepulcro" donde reposaba María Manuela Téllez (nombre falso pues Marianela no había tenido siquiera un nombre), descrita erróneamente por los viajeros como una "ilustre joven, célebre en aquel país por su hermosura" que había pertenecido "a una de las familias más nobles y acaudaladas de Cantabria" (Galdós 1984: 231). Ante ello, Galdós dice más adelante, no sin cierta ironía, que "bastaba leer esto para comprender que los dignos reporteros habían visto visiones" (Galdós 1984: 232). En este capítulo final, donde algunos críticos observan un entramado juego para confundir al lector respecto a la veracidad de la historia y la naturaleza de la verdad (Borrallo-Solís 2016: 13), nosotros encontramos el pretexto para ejercer su crítica: "Averiguada la verdad, de ella resultó este libro" (Galdós 1984: 232), dice el propio Galdós tras reflexionar sobre las palabras de aquel supuesto artículo del Times. A través de este juego, el novelista pone en evidencia el contraste entre aquella pomposidad fúnebre y la discriminación

5 “[...] as soft, susceptible, and malleable, both physically and emotionally" (Jagoe 1994: 57. La traducción española es del autor). 
e indiferencia que tuvo que sufrir Marianela en su vida. Como añadidura a la interpretación de Borrallo-Solís (2016), nosotros creemos que Galdós utiliza este juego de veracidad para poner en evidencia la doble moral de los Penáguila: el cuestionamiento no es si la historia de la Nela es cierta o no, sino la autenticidad de aquella caridad tardía. Marianela revela la fragilidad moral de aquel mundo que pretendía domesticarla.

\section{Diversidad funcional y rebelión: Los santos inocentes (1981) de Miguel Delibes.}

Cien años más tarde, Miguel Delibes se vale de la diversidad funcional para hacer una crítica de la tiranía rural que todavía podía percibirse en la España de los años sesenta y setenta en su novela Los santos inocentes (1981), pero también para enfatizar el contraste entre la acaudalada vida de una burguesía privilegiada, que disfruta de la vida en el campo para relajarse del agitado ritmo de la ciudad, y la precariedad de los trabajadores de las fincas, para quienes el ámbito rural no es más que su entorno de vida cotidiana. Por un lado, la novela es decididamente posmoderna: sus innovadoras características narrativas crean un texto que, sin palabras de más, "se mueve silenciosa y lentamente, pero sin detenerse, hacia el clímax de la historia" (Wogatzke-Luckow 1991: 114-115). Por otro lado, Los santos inocentes (1981), que Manuel Alvar califica como una novela narrada de "modo realista", es decir, "aceptable en sus posibilidades de verosimilitud" (1987: 62), se emparenta con la tradición de denuncia social y política (Aub 2007: 476), la "novela testimonio" o "novela social" (Sobejano 2003: 108), que caracteriza a una parte importante de la narrativa española durante la posguerra y franquismo en su afán por poner en evidencia una precaria realidad, marcada por grandes injusticias, habitada por personajes grotescos o moralmente cuestionables. Si bien estos textos cultivan lo que Gonzalo Sobejano (2003: 108) llama "el alegato y la denuncia", en Los santos inocentes (1981) la voz narrativa se mantiene ajena a emitir explícitamente cualquier juicio denunciatorio, permitiendo que la construcción dinámica del texto, el lenguaje y el énfasis en lo grotesco y escatológico produzcan sus efectos en el lector. Como estrategia para revelar las rígidas relaciones de poder en la sociedad rural castellana, y, sobre todo, para ponerlas en cuestión y revertirlas, Delibes se sirve de dos personajes discapacitados: el primero es Azarías, un hombre mayor de aproximadamente sesenta años con una importante discapacidad cognitiva; su representación abunda en lo grotesco y escatológico: sonríe, mostrando una boca con pocos dientes, babea y se expresa como un niño pequeño. Además, tiene como hábito orinarse las manos antes de desempeñar cualquier tarea. Azarías destaca por su gran afinidad con 
las aves, criando, primero, un búho, y más adelante, una grajeta a las que llama con el nombre genérico de "milana". Junto a Azarías, se encuentra la hija menor de Paco y Régula, Charito, apodada la Niña Chica por sus piernas delgadas y cortas, así como por su cabeza desproporcionalmente grande. Desposeída del lenguaje y de la capacidad de valerse por sí misma, su manera de comunicarse con el mundo se limita a un hondo berreo intermitente. La Niña Chica, que evidentemente ya no tiene la edad biológica de un bebé, está atrapada en una infancia perpetua por una evidente deficiencia encefálica. A su condición, hay que añadir el agravante de la pobreza.

Primeramente, nos detendremos en Charito, la Niña Chica. Su apodo ya hace alusión a su tamaño: pero también a su condición infantil, del mismo modo, a la ausencia de una personalidad definida debido a su discapacidad neuronal. De ahí que los demás no se refieran a ella como Charito. Su apodo también recuerda a alguna muñeca: y así es como parece tratarla Azarías, su contraparte "inocente":

[...] y en el trayecto, la Niña Chica emitió uno de aquellos interminables berridos lastimeros que helaban la sangre de cualquiera, pero el Azarías no se inmutó [...], al cabo de un rato, sus pupilas se volvieron hacia la Niña Chica, cuya cabeza se ladeaba, como desarticulada, y sus ojos desleídos se entrecruzaban, y miraban al vacío sin fijarse en nada y el Azarías se agachó, la tomó en sus brazos, se sentó al borde del talud, junto a la tierra removida, la oprimió contra sí y musitó, milana bonita, y empezó a rascarle insistentemente con el índice de la mano derecha los pelos del colodrillo, mientras la Niña Chica, indiferente, se dejaba hacer. (Delibes 1981: 27)

Imposibilitada de comprender lo que pasa, destaca la ausencia del lenguaje: este sustituido por lamentos casi animales, unos "berridos lastimeros que helaban la sangre de cualquiera”, ante los cuales Azarías no se inmuta. La dinámica entre ambos es similar a la que aquel sostiene con diversas aves, las "milanas" que cuida como mascotas propias. Viva, su cuerpo sin movimiento e indiferencia la aproximan, sin embargo, a la imagen de un animal muerto. Si bien su papel en la novela no es tan decisivo como el de Azarías, su discapacidad puede perturbar las relaciones entre los personajes, y esto a través del horror que provoca. Durante una visita de la Señora Marquesa, a quien se describe como "buena para los pobres" (Delibes 1981: 108) por su caridad, esta aparece acompañada de su hija Miriam, una joven señorita que, movida por la compasión hacia el estado de Azarías, le sigue brevemente en sus juegos y permite que le muestre su "milana". En esos momentos, escucha el berrido de la Niña Chica:

Pero, al cabo de pocos segundos, volvió a sonar el berrido de la Niña Chica y la señorita Miriam, espeluznada, ¿es cierto que es una niña la que hace eso? Y él, Azarías, cada vez 
más agitado, con la grajeta mirando inquieta en derredor, se volvió hacia ella, la tomó nuevamente de la mano y venga, dijo, y entraron juntos a la casa y la señorita Miriam, avanzaba desconfiada, como sobrecogida por un negro presentimiento, y al descubrir a la niña en la penumbra, con sus piernecitas de alambre y la gran cabeza desplomada sobre el cojín, y sintió que se ablandaban los ojos y se llevó ambas manos a la boca, ¡Dios mío! (Delibes 1981: 113)

Delibes confronta a la joven Miriam con el grotesco espectáculo de una niña deforme abandonada en la pobreza, desplomada sobre una cama y descrita en términos de un objeto descompuesto (piernecitas "de alambre", cabeza "desplomada"). Su inicial deseo de caridad y bondadosa compasión se ve, de pronto, perturbado por aquella visión que la horroriza pero ante la cual es incapaz de actuar.

Mientras que el papel de la Niña Chica es más pasivo, el de Azarías es más decisivo en su relación con el poder. A pesar de su estado, no está totalmente excluido del resto: como "inocente", es fácil de utilizar en tareas rutinarias sin pago alguno. Sin embargo, no estaba libre de la intransigencia del señorito Lupe, quien de pronto decide prescindir de sus servicios. Ante el reclamo de la familia de Azarías por el injusto despido, el señorito responde:

Todo lo que quieras, tú, menos levantarme la voz, sólo faltaría, que si a tu cuñado le aguanté sesenta y un años lo que merezco es un premio ¿oyes?, que buenos están los tiempos para acoger de caridad a un anormal que se hace todo por los rincones, y, por si fuera poco, se orina las manos antes de pelarme las pitorras, una repugnancia, es lo que es. (Delibes 1981: 67)

Si hasta entonces Azarías había sido parte de la vida económica, se trataba de una inclusión por conveniencia: era sumamente dócil y podía concentrarse en labores rutinarias, simples y molestas. Más que integrado, Azarías estaba sometido a una dinámica de explotación. Considerándolo un "anormal", el señorito Lupe enfatiza haberlo acogido por "caridad" que, más que una virtud cristiana, parece una obligación que busca, sin embargo, beneficiarse de su trabajo. La asociación de Azarías con lo escatológico (se orina las manos, tiene que ser llevado al bosque por Paco el Bajo para defecar) funge, por una parte, para "poner de manifiesto el ínfimo nivel en que se mueve la pobre humanidad" (Nañez Fernández 2003: 891) del personaje, pero por otra, le otorga un aire de repugnancia que mantiene una distancia considerable a la figura opresora. Le da, en cierto modo, una libertad de la que él es totalmente inconsciente.

Azarías muestra la desigual posición que sufren las personas con discapacidades en un entorno que no los considera como parte de la diversidad humana, sino como una distorsión del orden de las cosas. Pero es precisamente Azarías 
quien es capaz de alterar profundamente el estatus quo. Habla, por ejemplo, de temas incómodos para el resto. En un tiempo, sufre de alucinaciones en las que regularmente ve a Ireneo, uno de sus hermanos fallecido: "Pero las cosas de Azarías en seguida trascendían al Cortijo y los porqueros, y los pastores y los gañanes se hacían los encontradizos y les preguntaban, ¿qué fue del Ireneo, Azarías? Y el Azarías alzaba los hombros, se murió, Franco lo mandó al cielo" (Delibes 1981: 75). La mención de Franco y la alusión a la represión sufrida en la dictadura y las matanzas ocurridas durante la Guerra Civil fungen como una provocación en un contexto histórico donde el franquismo apenas ha terminado, en el momento de la publicación de la novela, aunque esta comenzó a ser escrita en los años sesenta (Wogatzke Luckow 1991: 107). Sin embargo, al mencionar al dictador en boca de un hombre que alucina, Delibes denuncia un hecho innegable: si bien al publicar la novela ha muerto el dictador, la rígida estructura casi feudal del cortijo perpetúa diversos mecanismos de opresión y abuso. Azarías, en su "inocencia", parece recordarles al resto su condición de siervos. Por su parte, preso de la locura, él está sin embargo libre de estas relaciones de poder al no tener plena conciencia de ellas.

Azarías expone el potencial de la diversidad funcional para echar abajo las estructuras de poder: y no es, precisamente, por su nula noción de la higiene personal. Azarías cuenta con una habilidad extraordinaria para domesticar y criar aves: una vez muerto el búho, recibe como regalo un polluelo de grajeta. Su relación con el ave es sorprendente, pues, una vez crecida, esta responde siempre a sus gritos: “iquía, quía!”, acudiendo a los hombros de su amo de inmediato. El señorito Iván era aficionado a la cacería de aves. Habiendo sido Paco el Bajo su asistente en la caza, de agudas habilidades cinegéticas, tiene que prescindir de sus servicios por una fractura de pierna. En su lugar, le pide a Paco que le preste a su cuñado Azarías precisamente por su don de aves. Aquella mañana de mala cacería, el señorito se encontraba malhumorado por su mala suerte. Sin embargo, al ir caminando juntos de repente atisban una parvada. Azarías identifica en ella a su propia milana, a la que llama con su grito, “ ¡Quía!”. El señorito Iván, excitado por la frustración, levanta su escopeta y se dispone a tirar. Azarías suplica: “¡no tire, señorito, es la milana! [...] ¡señorito, por sus muertos, no tire!” (Delibes 1981: 170). El señorito Iván, ligeramente perturbado por su sufrimiento, piensa que olvidaría pronto el incidente. Sin embargo, al repetir aquella tarde el mismo ritual de cacería, Azarías le tiende una trampa y lo ahorca con una soga:

¿pero qué demonios pretendes, Azarías? ¿es que no has visto la nube de zuritas sobre los encinares del Pollo, cacho maricón? Y así que el Azarías pasó el cabo de la soga por el camal de encima de su cabeza y tiró de él con todas su fuerzas, gruñendo y babeando, el señorito Iván perdió pie, se sintió repentinamente izado, soltó la jaula de los palomos 
y...¡Dios!...estás loco...tú, dijo ronca, entrecortadamente [...] el señorito Iván sacó la lengua, una lengua larga, gruesa y cárdena, pero el Azarías ni le miraba, tan sólo sostenía la cuerda, cuyo cabo amarró ahora al camal en que se sentaba y frotó una mano con otra y sus labios esbozaron una babolicona sonrisa, pero todavía el señorito Iván, o las piernas del señorito Iván, experimentaron unas convulsiones extrañas, unos espasmos electrizados, como si se arrancaran a bailar por su cuenta [...]. (Delibes 1981: 175-176)

Un pasaje paradójico si pensamos en el título de la novela, "santos inocentes". Azarías no es lo uno ni lo otro. Se reconoce la capacidad de un discapacitado mental de experimentar sentimientos auténticos, lazos emocionales hacia los que sostiene una fuerte lealtad. Su capacidad de apego emotivo a un animal contrasta con la crueldad del señorito Iván, un verdadero tirano incapaz de cualquier empatía. Sin embargo, de ese profundo sentimiento se deriva su necesidad de venganza: una que ejecuta con premeditación, sin remordimiento. Azarías comete un crimen, pero al mismo tiempo, da muerte a un tirano. En la escena, que contrasta la alegría vengativa de Azarías con la vulnerabilidad humana del señorito Iván, Delibes hace una apología de la rebelión popular. Apela a una transformación de las estructuras dictatoriales de poder que aún subsistían en la España rural. La diversidad funcional tiene una importante función política: sometido a un sistema de aparente inclusión que se trata más bien de un esquema de dominación, casi de esclavismo, Azarías tiene el arrojo que ningún otro de los empleados del cortijo había sido capaz de tener.

\section{Conclusiones}

El dúo que conforman estas novelas, de dos épocas distintas, nos presenta una constelación de personajes que permiten una mirada distinta sobre la diversidad funcional. Aunque Galdós no abandona el tono positivista y melodramático, permite, sin embargo, una dignificación del personaje discapacitado frente a la falsa bondad burguesa. Reconoce en Pablo las cualidades de un hombre, más que las de un ángel: el ciego recuperado pierde su inocencia al someterse a las condiciones de su clase social. Marianela, sin embargo, prefiere la muerte a la sumisión. Delibes muestra en Azarías a un personaje discapacitado cognitivamente, pero aún así, suficientemente tenaz para rebelarse contra el señorito, mientras la Niña Chica se ofrece como elemento perturbador. El título de "santos inocentes" encierra una gran paradoja. Si bien ambas novelas podrían primero parecer un retrato compasivo de la diversidad funcional, hemos visto que también expresan una crítica social que propone la discapacidad como herramienta de transformación. Así, los personajes de ambas novelas nos ofrecen un tránsito de la inocencia a la rebelión, y la esperanza de una historia alternativa. 


\section{Bibliografía}

Alvar, Manuel. 1987. El mundo novelesco de Miguel Delibes, Madrid: Gredos.

Alvarado Vega, Óscar G. 2008. "Marianela (1878): la apertura de (a) la visión como ceguera metafórica", en: Espiga 16-17: 115-140.

Anderson, Andrew A. 2015. "Necessary Sacrifices: From Romanticism to Naturalism in Galdós' Marianela", en: Bulletin of Spanish Studies 92: 907-929.

Aub, Max. 2007. Manual de historia de la literatura española, Valencia: Generalitat Valenciana.

Borrallo-Solís, Adela. 2016. "Monstruos y márgenes: reconsideración del capítulo final de Marianela de Benito Pérez Galdós”, en: Anales Galdosianos 51: 11-24.

Casalduero, Joaquín. 1984. “Introducción”, en: Benito Pérez Galdós, Marianela, Madrid: Cátedra: 11-47.

Delibes, Miguel. 1981. Los santos inocentes, Madrid: Planeta.

Farrag, Hayam. 2011. "La mujer fea en la narrativa de Benito Pérez Galdós y Taha Husayn. Modelo de mujer en Marianela y El árbol de la miseria”, en: Isidora. Revista de estudios galdosianos 17 (1): 37-152.

Gonzálvez, Isabel. 2006. Las fuentes de la invención. Presencia de Dante en las novelas galdosianas de la primera época, Madrid: Biblioteca Nueva.

Hartwig, Susanne. 2018. "Introducción: representar la diversidad funcional", en: Susanne Hartwig/Julio Checa (eds.), ¿Discapacidad? Literatura, teatro y cine hispánicos vistos desde los disability studies, Berlin: Peter Lang: 7-24.

Jagoe, Catherine. 1994. Ambiguous angels. Gender in the novels of Galdós, Berkeley-Los Angeles-London: University of California Press.

Mürner, Christian. 1990. Behinderung als Metapher, Bern und Stuttgart: Paul Haupt Verlag.

Náñez Fernández, Emilio. 2003. "Lo escatológico en Mesa, sobremesa, Los santos inocentes y Crónica de una muerte anunciada", en: Carmen Alemany (ed.), Con Alonso Zamora Vicente: Actas del Congreso Internacional "La Lengua, la Academia, lo Popular, los Clásicos, los Contemporáneos”, vol. II, Alicante: Universidad de Alicante: 889-903.

Pérez Galdós, Benito. 1984. Marianela, Madrid: Cátedra.

Ruiz, Mario. 1970. "El idealismo platónico de Marianela de Galdós”, en: Hispania 53: $870-880$.

Sobejano, Gonzalo. 2003. Novela española contemporánea. 1949-1995, Madrid: Marenostrum.

Wogatzke-Luckow, Gudrun. 1991. Figuren und Figurenkonstellationen im erzählerischen Werk von Miguel Delibes (1947-1987), Genève: Librairie Droz. 



\title{
Javier Luis Velloso Álvarez \\ Universidad Carlos III de Madrid \\ Cuerpos estancados, memorias evanescentes: Imágenes de la discapacidad y de la dependencia física, psíquica y sensorial en la narrativa de Rafael Chirbes
}

\begin{abstract}
Rafael Chirbes' career is one of the best examples of the rebirth in Spanish narrative of a novel strongly committed to its own political and social context, what is made explicit through a stark realism full of images that refer to social imaginaries that draw not a very lenient view with the country in the 20th and 21st centuries. In this sense, although this is a topic barely analyzed about his writing, the author not only offers a truthful and plural testimony of social customs regarding functional diversity and even of the experience of disability itself, but also provides some metaphorical echoes to disabled characters. This chapter aims to clarify the ways in which disability appears embodied in fictional characters from Chirbes' novels and secondly, to unravel the symbolic functions that these characters play from their divergent condition. In addition, the analysis will emphasize situations of dependence, especially those linked to disabilities stem from degenerative diseases common in old age: on the one hand, for what they say about dependent characters and about those who take care of them, on the other hand, because these images reveal profound connotations in relation to some central issues in the writer's work, such as political resistance and memory.
\end{abstract}

Keywords: Spanish contemporary fiction, disability, dependence, memory, Chirbes-Rafael

\section{Introducción}

La trayectoria narrativa de Rafael Chirbes es, sin duda, una de las que mejor ejemplifican el reverdecer en la España del siglo XXI de una novela fuertemente comprometida con su contexto político-social, frente a otra novela intimista, formalmente recursiva y más o menos experimental, a la que Gonzalo Sobejano denominó "ensimismada" (1988), y David Becerra Mayor, "novela de la no ideología” (2013). La obra de Chirbes rechaza claramente ambos marbetes, pues no solo entrevera toda ella un sentido ideológico profundo que hace de la recuperación de la dialéctica marxista de la lucha de clases su bandera, sino que además lo nutre con una enorme variedad de imágenes que, desde el más estricto realismo testimonial, remiten a imaginarios sociales perfectamente reconocibles de la España de los siglos XX y XXI. Representaciones narrativas que, cabalmente, 
se centran de manera prioritaria en el mundo de la clase obrera y la burguesía durante el franquismo, la Transición y la democracia, pero que dan cabida dentro de esos dos polos a una pluralidad de tipos en los que se cruzan otros vectores (raciales, de género, relativos a la capacidad) que definen las relaciones de poder de cada etapa, y en los que cobran la relevancia también las superestructuras culturales y simbólicas derivadas de su confluencia.

En este artículo trataré de trazar un mapa de las imágenes que desde el prisma de la discapacidad y/o la diversidad funcional ${ }^{1}$ encontramos en la trayectoria novelística del autor: en primer lugar, aproximándome al tipo de discapacidad que presentan los personajes funcionalmente diversos y valorando la relevancia de tales personajes en el diseño actancial de cada novela. A continuación, analizaré el lugar que los caracteres discapacitados ocupan en el universo ficcional de cada obra desde el punto de vista de la oposición categorial inclusión/exclusión, considerando principalmente dos vertientes: 1) el grado de inclusión/exclusión discursiva de aquellos personajes que en la novelística chirbesiana presentan una discapacidad, valorando cuál es el sesgo aplicado en su representación por un escritor no afectado por dicha condición; y 2) el grado de inclusión/exclusión social de los personajes a la luz de los imaginarios sobre la discapacidad en la España de los siglos XX y XXI que se derivan de la lectura de novelas escritas desde el más profundo afán realista. En tercer lugar, resulta mandatorio realizar algunas consideraciones acerca de las situaciones de dependencia física, cognitiva y sensorial, que, como veremos, son muy recurrentes en la narrativa del autor. En adelante entenderemos la dependencia tal como la define la vigente Ley 39/2006 de promoción de la Autonomía Personal y Atención a las personas en situación de dependencia:

1 En adelante utilizaré ambos términos indistintamente: considero que el modelo acuñado en el año 2005 en el Foro de Vida Independiente y definido en sus líneas maestras por Javier Romañach, Agustina Palacios y Manuel Lobato $(2006,2007,2010)$ es, sin duda, el más remiso a las connotaciones negativas y el estigma que perviven en la categoría discapacidad propia del modelo médico y social; de hecho, la concepción de la diversidad funcional como una condición connatural a toda persona humana resulta muy adecuada para el enfoque escogido para este artículo. Sin embargo, no parece que exista consenso en el ámbito académico sobre lo conveniencia del uso de una categoría sobre otra: por un lado, por la amplitud semántica y escaso recorrido teórico de la más reciente, y por otro, porque todavía es muy limitada su aceptación fuera del contexto hispánico peninsular. Por ello, sin negar las diferencias conceptuales que una y otra presentan, se aboga aquí, a efectos explicativos y pragmáticos, por un uso equivalente e integrador de ambas. 
Estado de carácter permanente en que se encuentran las personas que, por razones derivadas de la edad, la enfermedad o la discapacidad, y ligadas a la falta o a la pérdida de autonomía física, mental, intelectual o sensorial, precisan de la atención de otra u otras personas o ayudas importantes para realizar actividades básicas de la vida diaria o, en el caso de las personas con discapacidad intelectual o enfermedad mental, de otros apoyos para su autonomía personal. (Art. 2.2 LPAPA 39/2006, de 14 de diciembre)

Lejos de pretender establecer una relación consecutiva o de identidad entre las situaciones de discapacidad y la dependencia, la remisión a la ley no es inocente porque, por un lado, esta deja claro en su articulado que la primera puede ser causa de la segunda, y por otro, porque, en la medida en que el escritor abogaba por una literatura "con fecha" (Jacobs 1999: 182), entonces el análisis de las imágenes y representaciones de la dependencia desde este prisma nos da pie a una reflexión sobre el papel asistencial que ha asumido el Estado español en la historia reciente y su evolución a lo largo del tiempo. Pero, además, las relaciones que se establecen entre las personas en situación de dependencia y sus cuidadores ofrecen información relevante en relación con otros tipos de subalternidad y tienen, como veremos, muchas connotaciones simbólicas y éticas estrechamente relacionadas con cuestiones absolutamente centrales en Chirbes, como son el compromiso con los oprimidos o la pervivencia de la memoria.

En este sentido, es indudable que en la narrativa del autor la discapacidad funciona muy a menudo como metáfora o, en términos de Mitchell y Snyder, como prosthesis (2000), y por ello debe admitirse que la configuración de estas imágenes se efectúa a menudo desde parámetros propios de la "normalidad". La pregunta es, entonces, si más allá del valor estético que otorga a la condición, el discurso literario chirbesiano se adscribe sin fisuras a alguna de las visiones hegemónicas de la discapacidad, o, por el contrario, pueden rastrearse en sus novelas visos de una mirada más compleja que problematice adecuadamente la cuestión según los parámetros teóricos que desde los Estudios Culturales y los disability studies han venido proponiendo en los últimos tiempos.

Presentados, pues, los objetivos, es preciso realizar una aclaración previa: la mayor parte de las representaciones de la discapacidad que veremos son consecuencia de procesos traumáticos o patologías previas, a menudo ligadas con enfermedades neurodegenerativas preponderantes en la tercera y cuarta edad. Nuestro objeto no es el estudio de lo patológico y su sintomatología, ni tenemos intención de trazar relaciones lógico-causales que refuercen estereotipos sobre la ancianidad, la discapacidad y la vida dependiente: lo que pretendo es, sobre todo, arrojar luz sobre la representación narrativa de las discapacidades, sea cual sea su origen, para decodificar las relaciones (simbólicas, políticas, corporales) a las que estas diferencias dan lugar en entornos por lo general remisos a la inclusión. Por 
otro lado, la inevitable homogeneización que en esta comunicación se haga sobre la categoría discapacidad tendrá sentido para encontrar lo que Spivak llama un "esencialismo estratégico" (1988), pues, en efecto, los tipos de discapacidad y las situaciones particulares de los personajes representados son muy diversos. Su estudio conjunto, sin embargo, nos servirá para analizar las imágenes de la discapacidad desde el punto de vista de parámetros como la subalternidad, la inclusión/exclusión o el estigma.

La propia Clasificación Internacional del Funcionamiento, la Discapacidad y de la Salud (CIF), adoptada por la OMS en 2001 evita la referencia a lo patológico y define, de hecho, las discapacidades como "los aspectos negativos de la interacción entre un individuo con una condición de salud dada y los factores contextuales (ambientales y personales)" (Fernández López 2009: 778). Este enfoque, basado en un modelo denominado biopsicosocial, es el que va a ser más productivo para este estudio, pues, como veremos, en los personajes de Chirbes que manifiestan una discapacidad, solo muy excepcionalmente aparecen identificadas patologías concretas que pudieran predisponer al lector a asumir determinadas perspectivas unilaterales; y si bien muchas imágenes literarias remiten a patrones clínicos fácilmente identificables, también lo es que el énfasis en las novelas se pone en las dificultades relacionales entre su condición de salud y un entorno a menudo hostil.

\section{La discapacidad y dependencia física en la vejez: Los disparos del cazador}

Chirbes tardó cuatro novelas en representar la discapacidad, pero cuando por fin lo hizo en Los disparos del cazador (Anagrama 1994), no relegó la cuestión a un plano secundario, sino que lo convirtió en uno de los ejes fundamentales en la caracterización de Carlos Císcar, protagonista absoluto de la novela y narrador autodiegético que, en su ancianidad, echa la vista atrás en un intento, plagado de hipocresía, por justificar sus vaivenes ideológicos y su doble moral ante su hijo, ante el lector y ante sí mismo: a través de sus recuerdos y confesiones avergonzadas van desvelándose los vicios y miserias de un personaje arribista y manipulador, dominado toda su vida por el ansia de poder y por un impulso sexual irrefrenable.

Desde el punto de vista intelectual y sensorial, es pues, un personaje lúcido y plenamente consciente de sus propios errores, errores que retornan vívidos a su mente amalgamados en la bruma culpable de forma de memoria. La dicotomía que se establece entre la mera remembranza inocua y la memoria dolorosa es transparente: 
Le pido a Ramón que levante las persianas y me lleno de recuerdos que busco que sean objetos perfectos, cristales exentos de la densidad envolvente de la memoria. Y me pregunto por qué no puede haber recuerdos sin memoria. (Chirbes 2013: 160) ${ }^{2}$

Así pues, la relación de la memoria con la ancianidad es conflictiva, pero no porque la edad amenace su pervivencia, sino justo al contrario, porque la memoria permanece insistente como un espectro, o como "un enemigo al que nunca se derrota" (Chirbes 2013:187). La razón por la que Carlos Císcar no puede escapar de ese enemigo cargado de remordimientos no es otra que su discapacidad física, que no le permite franquear, sin ayuda, los límites de su propio hogar, plagado de objetos, fotografías y olores que actúan como dispositivos mnemónicos, y que, además, es un espacio cada vez más limitado, a medida que la degeneración física avanza.

Una merma física que hace también que la potencia sexual que en el pasado era el estandarte de su virilidad y poder, torne en su senectud en onanismo azorado y patético:

No soy fuerte. Soy simplemente obeso y mi vientre es blanco como el de un recién nacido. Temo que Ramón sospeche esas desoladoras ceremonias, e incluso las espíe [...] al recoger la habitación tiene que encontrarse con las huellas de mi dudosa energía en las ropas de la cama. (Chirbes 2013: 158)

Los fragmentos citados evidencian una identidad casi absoluta entre vejez y decrepitud, y en toda la novela se insiste en el aislamiento al que se ve sometido el anciano, que de ser un padre de familia respetado y querido por su inocente mujer, pierde primero a esta por fallecimiento, y después a su hijo Manuel, cuyo abandono y rencor es el recordatorio más claro de su culpabilidad. La decadencia física, descrita por el personaje con crudeza y negatividad, va acompañada, pues, de cada vez mayor exclusión, tanto por parte la familia como de una sociedad para la que simboliza un orden político y moral difícil de aceptar públicamente.

La visión pesimista acerca de un país en el que los ancianos con discapacidad son arrojados a los márgenes es, como veremos, una constante en la obra del autor, pero en el caso del protagonista de Los disparos del cazador debe mantenerse la cautela ante la explicación de su soledad y aislamiento como una consecuencia directa de la hostilidad general del entorno hacia un anciano con facultades físicas menguadas. Así, aunque Carlos Císcar se victimiza constantemente y se presenta como un ser indefenso y abandonado, sabemos por el juego contrastivo de su caracterización que los motivos de su repudio familiar son bien

2 Todas las citas están tomadas del volumen Pecados originales (Anagrama 2013) reedición conjunta de las novelas La buena letra y los disparos del cazador. 
distintos. Por ello, en la dicotomía inclusión/exclusión sobre la que trabajamos, su falta de agencia sobre el entorno y su marginación no pueden explicarse, o al menos no sin muchas reservas, en base a su condición física o edad, sino más bien al daño causado a lo largo de su vida, que le vuelve como un aldabonazo en forma de abandono en los últimos años.

En esta situación sobrevuela, asimismo, un cierto aire de ajuste de cuentas por parte del autor implícito: en efecto, el anciano Carlos Císcar se enfrenta a dificultades de las que ya fue testigo como cuidador de su cuñado Manuel, fallecido tempranamente a causa de una enfermedad degenerativa. La relación de ambos, que pasa de la servidumbre puramente laboral a la amistad, permite a Carlos ganarse la confianza de su hermana y poner un pie, matrimonio mediante, en una familia burguesa en la que es percibido como un intruso. La ironía trágica es aún mayor si se compara la relación de confianza que le unía a su cuñado fallecido y que acaba traicionando, frente a la frialdad y el escaso conocimiento íntimo que tiene de Ramón, su "criado" [sic], ese hombre que silencioso permanece acompañándole día a día y que ha acabado por convertirse en "mi mano derecha, o mejor sería decir en mis dos manos" (Chirbes 2013: 147). El narrador se ve como la parte más débil y expuesta de una relación desigual:

Me desazona [...] sigo sin conocerlo: de él solo sé su ritual de orden, que interpreto como una permanente demostración de fidelidad, que a mí no deja a veces de incomodarme, como puede desagradar el contacto con la lengua de un gato. Él, sin embargo, parece comunicarse conmigo por un transmisor oculto: adivina mis secretos deseos, mis necesidades $[\ldots]$ y lo hace con una seguridad que no deja de parecerme impúdica. (Chirbes 2013: 239)

De todo lo dicho, se deduce que, si bien el narrador se emplea a fondo por despertar la compasión del lector, el autor implícito toma clara distancia respecto de esa mirada, aunque sí es identificable un principio de empatía con la vulnerabilidad humana. En este sentido, la escena en la que Carlos es rescatado de un accidente en mitad del bosque por su cuidador es, sin duda, la que más le humaniza, pues, por primera vez y casi al final de la novela, parece abrirse en su interior un pequeño atisbo de gratitud y reconocimiento del otro, más allá del egotismo de los intereses económicos y sexuales que en el pasado fueron el único incentivo de su día a día:

Sus piernas son las mías, sus pulmones son los míos, suda por mí, y siento vergüenza de verme así llevado, inútil, y también una inmensa gratitud. Es la primera vez desde los lejanos tiempos de mi infancia en que el roce de otra piel, y el sudor, y el ritmo de la respiración que nace en el estrecho contacto de los cuerpos no nacen de un impulso sexual. (Chirbes 2013: 242) 


\section{La discapacidad física en La larga marcha}

El caso de Pedro del Moral, uno de los muchos personajes que habitan el universo coral de La larga marcha (Anagrama 1996), es el único ejemplo que encontramos en una novela de Chirbes en el que la discapacidad no tiene una relación directa con una edad avanzada, sino que nace de una condición de salud que, aunque sobrevenida, acaba por ser permanente y no varía en lo esencial hasta el final de su vida.

Pues bien, a diferencia de lo que ocurría con Carlos Císcar en Los disparos, aquí la mirada que Chirbes proyecta sobre el personaje es manifiestamente compasiva, aunque no paternalista, sino empática: la identificación con los marginados, con los subalternos, se manifiesta, en efecto, como un rasgo constante en la obra chirbesiana. En este sentido, ya antes de su discapacidad Pedro es la viva imagen del fracaso: tras haber participado en la guerra en el bando fascista, acaba relegado a un oficio de ínfima consideración social, limpiabotas, viudo por la muerte fulminante de su joven esposa, y con dos hijos a los que mantiene a duras penas. La soledad le lleva a entregarse al alcohol y a las prostitutas y finalmente, a intentar suicidarse lanzándose a las vías del tren. La tentativa frustrada provoca, sin embargo, la amputación de sus dos piernas, lo que le obliga a vivir con una discapacidad física severa el resto de su vida. Su nueva condición, por la que se ve obligado a desplazarse por medio de un vehículo con ruedas, supone así, el descubrimiento de un sinnúmero de barreras que dificultan su actividad cotidiana. Por un lado, barreras arquitectónicas y urbanísticas, las más ostensibles y evidentes:

La ciudad era distinta si uno la veía desde la silla de ruedas. Tenía aceras, desniveles, cuestas que antes ni siquiera le habían llamado la atención y que ahora, sin embargo, le parecían interminables; y tenía escaleras: por ejemplo, algunas entradas de la Plaza Mayor estaban precedidas por empinadas escaleras por las que él ya no podía subir cuando venía de Tejares. (Chirbes 1996: 143)

Pero también, por otro lado, barreras simbólicas que nacen tanto del nuevo trato que recibe de los demás como de su autopercepción degradada: la mutilación de su cuerpo, y el origen ignominioso de la misma, lleva aparejada una mutilación aún mayor de su propia dignidad:

Algunas mañanas se hacía acompañar por José Luis, que se ofrecía a empujarlo a ratos, sin duda porque así podía avanzar atento a ejercer una actividad que le permitía mantener la vista al frente y no volver continuamente la cabeza para encontrarse con las miradas de los compañeros de escuela que se cruzaban con él. (Chirbes 1996: 193) 
Así pues, los capítulos protagonizados por el personaje ofrecen una idea bastante certera de lo que suponía ser discapacitado en plena posguerra: la inclusión era un concepto desconocido, y el estigma (en este caso, muy connotado moralmente) la norma; un caldo de cultivo propicio para la consolidación de imaginarios que terminaron relegando a la mayoría a la marginación social y económica, con la intervención puntual de la beneficencia eclesiástica o de los centros dependientes del Auxilio Social.

En lo que se refiere a la cuestión de la dependencia, vemos que, pasado un tiempo prudente en el que ha de familiarizarse con la precaria silla que le transporta, Pedro del Moral lleva una vida aparentemente autónoma y es capaz, con las dificultades consabidas, de desenvolverse en su día a día. Es por ello que decide prescindir de toda ayuda y enviar a José Luis a un internado en León, si bien reconoce en privado que "no podría vivir sin el chico" (Chirbes 1996: 161). El estigma, efectivamente, va ejerciendo su función y perfilando un horizonte de pesimismo en el que el personaje se ve a sí mismo como una pesada carga para quien se hace cargo de sus cuidados: su hijo. Muchos años, después, siendo este adolescente, le explicará su nueva relación amorosa con una mujer, Juana, y su verdad, que entrevera una asunción acrítica de los parámetros discursivos de "la normalidad", sale a relucir sin ambages:

Y se enredó en una interminable explicación acerca de cómo él no podía vivir solo, no por las necesidades que pudiera tener un "varón" [...] sino también porque “iqué cojones pinta solo un inútil como yo? Tendría que besar por donde pisa ella, por haber aceptado cargar con la mitad de un hombre [...]". [...] "Y tú eres lo primero para mí, hijo", prosiguió, "pero soy un inválido ${ }^{3}$ ¿ YY te imaginas lo que es llevar una casa desde una silla de ruedas?" (Chirbes 1996: 264)

Una verdad con la que su hijo empatiza directamente: José Luis es, antes de la aparición de Juana, la única persona que reconoce la dignidad de su padre y se responsabiliza de su cuidado. Es por ello que, en su regreso a Salamanca, siente la necesidad de redimir las ocasiones en las que pudo renegar de él durante su infancia, en una sutil y bella escena:

Estuvo allí sentado, al lado de él, ayudándole, abriendo y cerrando las latas de betún, a medida que su padre las necesitaba, acercándole cepillos y bayetas [...] no le importaba que lo vieran allí sentado los compañeros del colegio. Miraba las manos de su padre moviéndose encima de los zapatos a toda velocidad y sentía ganas de cogerlas entre las suyas. (Chirbes 1996: 266)

3 La cursiva es mía. 
La caracterización de su alter ego José Luis del Moral como un personaje extremadamente frágil y sensible pone, una vez más, de manifiesto, cómo el autor encontraba en las situaciones de vulnerabilidad una grieta de esperanza ante la impiedad de los poderosos: los cuidados mutuos, entendidos no solo en un sentido económico-social sino también afectivo, son la mejor forma de resistencia, el único refugio de los débiles ante la opresión y la intemperie. Por ello, si hablamos de dependencia, deberíamos considerarla aquí en un sentido bidireccional.

\section{La discapacidad y la dependencia física, cognitiva y sensorial en la vejez en La caída de Madrid}

En la coral La caída de Madrid (Anagrama 2000), en la que "el verdadero protagonista $[\ldots]$ no es un personaje sino un momento: el comienzo de la transición" (López Merino 2005), uno de los caracteres que, pese a sus escasas apariciones, es fuente constante de conflictos familiares y espejo de las contradicciones de un país sumido en la incertidumbre es Amelia, la anciana esposa del patriarca José Ricart.

Juan Miguel López Merino señala que “Amelía’ significa distrito gobernado por un ámel, que, entre los árabes, es el jefe de un distrito; Amelia es por tanto 'la gobernada' " (2005), una aproximación onomástica que ya apunta las principales señas de identidad del personaje. En efecto, es Amelia Viñal ${ }^{4}$ un personaje que presenta severas discapacidades físicas, intelectuales y sensoriales que le dificultan hasta el extremo cualquier interacción con su entorno. Discapacidades que, por lo que podemos inferir de las descripciones del narrador y de los monólogos interiores del personaje, derivan de algún tipo de enfermedad neurodegenerativa como la demencia o la enfermedad de Alzheimer: en su mente se mezclan y confunden personas y tiempos, padres, maridos e hijos, recuerdos de infancia y madurez... Amelia vive, en palabras de José Manuel Camacho Delgado, "perdida entre las brumas del pasado, sufriendo en la cotidianeidad los horrores de una vida dura y a la intemperie, a pesar de haber pertenecido al bando de los vencedores de la guerra civil y de haberse casado con uno de los prohombres del régimen" (2011: 93).

En efecto, Amelia es depositaria de la memoria que los afectos del régimen trataron de borrar del mapa tras la muerte del dictador, una memoria evanescente y en proceso de degradación continua, en la que los sucesos de ámbito familiar tienen claramente alcance público: en los destellos caóticos de la mente

4 El apellido de naturaleza vegetal también tiene un significado en el que las alusiones a animales depredadores y herbívoros se reservan a los hombres. 
de la anciana están la guerra civil, la educación rígida y el miedo permanente a la figura paterna, el desprecio y las infidelidades de su marido, o la muerte de uno de sus hijos a los tres años, un hecho que entronca con las carencias económicas y sanitarias de la primera posguerra. Su situación es incluso interpretada por su marido como una venganza: su nebulosa memoria, que se reduce a una estructura informe de "tinieblas, fogonazos dolorosos que le vienen siempre del pasado, amargura, desolación, incomprensión” (Camacho Delgado 2011: 93), es un recordatorio permanente del daño infligido por la dictadura contra las mujeres, contra los vencidos y, en fin, contra los que hubieron de sobrevivir a las penurias de la posguerra bajo la mano de hierro del aparato dictatorial. Es, pues, evidente, que el personaje de Amelia tiene un valor simbólico innegable desde esta perspectiva mnemónica.

Amelia es, además, la viva imagen de la exclusión y la marginación: encerrada permanentemente en su habitación, atada en la cama y separada de una familia con la que comparte techo pero apenas se comunica, encarna la indignidad y humillación a la que, por vergüenza o hastío, han sido sometidos muchos discapacitados y dependientes dentro del ámbito familiar. Tampoco hay aquí mediación alguna de un Estado que a la altura de 1975 había desarrollado un cuerpo legal e institucional muy elemental para la protección de la vejez y la discapacidad: los Ricart son una familia pudiente para la que la demanda de asistencia pública sería poco menos que deshonrosa, por lo que dejan su cuidado a cargo de Lurditas, encargada del resto de quehaceres del hogar.

Afirma Concepción Arroyo Rueda que "los ancianos que presentan una imagen de deterioro se convierten en un grupo socialmente estigmatizado en muchos discursos cotidianos, a los que se les etiqueta como personas 'ociosas', 'improductivas', como 'carga familiar', 'etcétera'” (2013: 56). El trato familiar dispensado a Amelia es perfectamente representativo de este tipo de discursos, y en él aflora la hipocresía de sus parientes, en apariencia fieles a los principios morales y religiosos de un régimen que ensalzaba a la familia nuclear como base y garantía de mantenimiento del Estado.

En este contexto general de exclusión y apartamiento, Tomás Ricart, hijo de Amelia y José, es el único resquicio de esperanza en la podredumbre moral que impera en el entorno. De hecho, pese a ser Lourditas la que asume las responsabilidades más directas en el cuidado material de la anciana, no es inocente el protagonismo que Chirbes da al hijo en otro tipo de cuidado trascendental, el afectivo. Así, a la relación de ambos dedica el autor uno de los capítulos de mayor ternura y lirismo de su obra completa: en las visitas del apocado hijo a la madre se hace patente la visión esperanzada del encuentro entre los que, en la fragilidad, resisten y mantienen viva, una dignidad amenazada por todos los frentes. 
Es asimismo Tomás el que apunta la metáfora más certera para representar la indefensión de su madre:

Él volvió a tender el brazo y ahora no le importaba aquella confusión de papeles equivocados: amigo, marido, hijo...le acariciaba el pelo, y se inclinó otra vez sobre ella y la besaba, y la decía: "No llores", y ya no le parecía una niña la mujer, sino un pequeño y sufriente animal abandonado. (Chirbes 2000: 220)

Pero, además, a nivel discursivo, Tomás se presenta como el aval mnemónico que pone orden en los recuerdos cruzados de su madre y contribuye a generar un relato honesto y veraz de las experiencias amargas y desprecios sufridos a lo largo de su vida. No sustituye, pues la voz de aquella, que el narrador mantiene a través de esa "tercera persona compasiva" que introduce por medio del Estilo indirecto Libre y que hace partícipe al lector, a través de un discurso quebrado y caótico, de la experiencia misma de la discapacidad cognitiva; sino que la complementa y la amplía (podría decirse que ejerce una cierta función de "crítica") partiendo de los recuerdos subjetivos de la niñez. Diríase que Tomás Ricart, en este sentido, asiste a la dependiente en su función de cuidador también como portavoz narrativo secundario y garante de la dignidad que pervive en esa memoria incómoda.

\section{La discapacidad y dependencia física, cognitiva y sensorial en la vejez en En la orilla}

Finalizamos nuestro recorrido a las imágenes de la discapacidad y la dependencia en las obras de Chirbes con En la orilla (Anagrama 2013), una novela en torno al drama existencial de su protagonista, Esteban, que da cabida, sin embargo, a través de un planteamiento coral asimétrico, a otras voces, la mayoría de desempleados, inmigrantes y personas que sufren con especial crudeza la precariedad y efectos de la crisis económica que dio comienzo en el año 2007. La figura que merece ahora ser analizada es la del padre de Esteban, un anciano en la recta final de su vida que presenta múltiples discapacidades físicas, intelectuales y sensoriales asociadas tanto al padecimiento de enfermedades como a la degeneración propia de la senectud más avanzada. Habla su hijo:

Hace muchos meses que el viejo no habla, y ni siquiera se sabe muy bien si mira. Ver sí que ve [...] oír también oye, aunque no es seguro que entienda [...] No habla, pero podría escribir, pedir las cosas por escrito, expresarse por gestos, y tampoco lo hace. No muestra el menor interés en comunicarse. Los médicos le han hecho pruebas, escáneres, y dicen que no tiene el cerebro dañado, no se explican lo que puede ocurrirle. La edad, los noventa y pico años. Se ha convertido en un maniquí articulado. (Chirbes 2013: 30) 
Son muchas y recurrentes las descripciones de este padre anciano que se convierte, a ojos de su hijo, en un peso muerto, en materia sin vida y constante fuente de frustración: dice Germán Labrador que "el cuerpo del padre paralítico, anciano, mudo, se vuelve omnipresente para el hijo, que no sabe cómo asumirlo, ni cómo relacionarse con él" (2014: 233). Así pues, la heterocaracterización del padre discapacitado, en la que son constantes las comparaciones y analogías del cuerpo del anciano con las aguas estancadas de un marjal en estado de pudrición, aparece muy marcada por la negatividad que emana del punto de vista de Esteban, absolutamente preponderante en toda la novela: en esta es donde afloran más claramente los problemas en la representación/sustitución discursiva de la discapacidad cognitiva que refiere Susanne Hartwig (2018: 187-210), pues a priori no parece haber interés alguno por acometer una representación empática del fluir de la conciencia (o su ausencia) del padre, al que ni siquiera se identifica por su nombre propio. Las connotaciones metafóricas de su discapacidad en relación con la cuestión de la memoria son, como en otras ocasiones, autoevidentes: la muerte lenta del padre, acelerada finalmente por la inmolación que su hijo planea, es "memoria que se borra" sin haber sido redimida ni escuchada, la memoria de los vencidos y reprimidos por la dictadura.

$¿$ Quiere esto decir que Chirbes se conforme con ofrecernos una perspectiva unilateral y parcial que silencia por completo al discapacitado, aquí convertido en objeto? No, pues, por un lado, introduce la voz narrativa de ese hombre desprovisto de memoria a través del anverso de un viejo calendario que permanece incógnito para su familia y es rescatado por un narrador externo y demiúrgico, un relato clave para dar un perfil redondo a un carácter al que, de otro modo, solo llegaríamos a través del relato de Esteban. Pero, además, ese relato tan profundamente connotado por la negatividad, el estigma y la mirada patológica no oculta en ningún momento su radical subjetividad: la del hijo que, desde su más tierna infancia, hubo de enfrentarse a la incomprensión y el rigor de un padre cuya ortodoxia moral y política opacó el afecto paterno-filial. El rencor evidente de sus palabras, patente en la descripción de las cargas que el cuidado del padre comporta, no anula, sin embargo, la empatía, la contradicción, incluso la compasión. Esteban es, en efecto, un personaje altamente complejo, que constituye en sí mismo un campo propicio para ejercer sobre él una lectura crítica acerca de los modos de representar narrativamente la discapacidad.

Por lo que respecta a la cuestión de la inclusión/exclusión, resulta inexcusable tomar en consideración no solo la exclusión discursiva o la simbólica, que se concreta en el ostracismo que sufre por parte de la mayoría de sus hijos y de su entorno más cercano, sino también la exclusión entendida por parte de un Estado que, en plena crisis, recortó al máximo las ayudas asistenciales a la vejez 
y la dependencia. Es por eso que Esteban se ve obligado después de la ruina económica a despedir a la joven colombiana Liliana, cuya nacionalidad y género no son, en absoluto, casuales, pues en efecto:

La transferencia de trabajo de cuidado, de forma remunerada o no, supera las fronteras nacionales y configura lo que se han denominado "cadenas globales de cuidado", cadenas de dimensiones transnacionales que se conforman con el objetivo de sostener cotidianamente la vida y en las que los hogares se transfieren trabajos de cuidados de unos a otros en base a ejes de poder entre los que cabe destacar el género, la etnia, la clase social y el lugar de procedencia. (Robledo Martín et al. 2017: 186-187)

En la caracterización de Liliana se vislumbra, pues, también la agudeza del escritor para hacer visible la relación entre la tarea de los cuidados y otros tipos de subalternidad, en una época histórica en la que este tipo de tarea se ha externalizado y profesionalizado y ya no pertenece a las labores tradicionalmente consignadas a los y las "criados/as del hogar" en su sentido más amplio.

Una vez cesada la primera cuidadora, padre e hijo quedan a la intemperie, y este último se ve obligado a asumir el rol de aquella: en la vulnerabilidad, en el aislamiento social es, de nuevo, donde nace la solidaridad, el reconocimiento mutuo y la empatía. De modo similar a lo que ocurría en La caída de Madrid con Tomás Ricart y su madre, el protagonista se sabe único garante de la pervivencia del padre y de una memoria que se perderá para siempre en el tiempo; e incluso la solución final que adopta, a saber, la autoinmolación de ambos en el marjal de Olba, pese a lo terrible del hecho, es producto de esa consciencia. La relación de los modos de (in)comunicación del padre y el hijo, de la supervivencia a duras penas de ambos y de los cuidados y tareas que la conservación del padre exige ocupan un lugar absolutamente central en la novela, y en tales pasajes tiene mucha relevancia no solo ese vínculo paternofilial afilado y complejo entre dependiente y cuidador, sino también el propio género masculino de ambos. Afirma Germán Labrador:

Algo profundo se juega en términos simbólicos entre estas escenas comparables de hombres en climaterio cuidando de los cuerpos descompuestos de sus progenitores. En ausencia de madres. Este es el teatro de una masculinidad no estatal, posedípica, donde el hijo que no quiso matar a su padre y el padre que no quiso comerse a su hijo se entregan vulnerables a un final ritual antropofágico [...] Mater Dolorosa doblemente invertida: el hijo abraza al padre, y, ambos yermos y estériles, se ofrecen al frío de la historia y la muerte. (2014: 233)

El acto tanático con el que finaliza la novela aparece como la única vía de redención posible en un mundo abnegado de suciedad y corrupción moral. La escena precedente, en la que el hijo lava al padre para depurarlo de la ponzoña y malos 
olores de un mundo en ruinas, es en este sentido altamente simbólica: "Le miro las manos que fueron hábiles y fuertes, se las acaricio pudorosamente, como si no hiciera más que lavárselas, pero se las acaricio. Retengo las ganas de besárselas." (Chirbes 2013: 20). Un último gesto de gratitud y dignificación, con connotaciones eminentemente religiosas hacia un hombre al que su compromiso político primero, y su discapacidad después, convierten en un marginado, discursiva y socialmente hablando. La abyección y degradación que los discursos hegemónicos atribuyen, pues, al discapacitado, al anciano, se traslada a través de este gesto a aquellos que representan una normalidad inmóvil y destructora, esta sí, moralmente cenagosa y pútrida.

Para concluir, podemos afirmar que En la orilla es una obra paradójica, pues si por un lado es cierto que las resonancias simbólicas de la discapacidad son más evidentes que nunca; también lo es que se trata de la novela que incide de manera más explícita en la vertiente social de las problemáticas en relación a los cuidados, como son las carencias asistenciales de un Estado de Bienestar en proceso de derribo o las relaciones entre diversidad funcional y otros tipos de subalternidad política y sociológica, que afectan no solo a los dependientes sino también a sus cuidadores. Una obra que, además, si bien ofrece una mirada a menudo compasiva de la situación del discapacitado, no rehúye la complejidad y la contradicción, por medio de la polifonía y la multiplicación de puntos de vista.

Hemos de insistir, en todo caso, en que la piedad que el autor muestra en este caso, como en otros, con el personaje discapacitado no es exclusiva de esa condición, sino que se extiende a todos aquellos personajes que de un modo u otro son especialmente vulnerables en un contexto social de depredadores y depredados, sea por una condición de salud dada, por su género, su raza o por su misma ideología. Aunque más que piedad, de lo que deberíamos hablar es de identificación y empatía con los débiles: la de un escritor que se supo toda su vida en el bando de los vencidos y que siempre fue extremadamente crítico con los sistemas políticos y económicos que se sirven de la dominación y deshumanización para romper los lazos afectivos entre los individuos.

\section{Bibliografía}

Arroyo Rueda, María Concepción. 2013. "La dimensión emocional del cuidado en la vejez: la mirada de los adultos mayores", en: Cuadernos de Trabajo Social 26 (2): 337-347.

Becerra Mayor, David. 2013. La novela de la no-ideología, Madrid: Tierradenadie. Camacho Delgado, José Manuel. 2011. "La eternidad llega a su fin. La caída de Madrid, entre la mitología franquista y la ventolera democrática”, en: Augusta 
López Bernasocchi/José Manuel López de Abiada (eds.), La constancia de un testigo. Ensayos sobre Rafael Chirbes, Madrid: Verbum: 63-102.

Chirbes, Rafael. 1994. Los disparos del cazador, Barcelona: Anagrama.

Chirbes, Rafael. 1996. La larga marcha, Barcelona: Anagrama.

Chirbes, Rafael. 2000. La caída de Madrid, Barcelona: Anagrama.

Chirbes, Rafael. 2013. En la orilla, Barcelona: Anagrama.

Chirbes, Rafael. 2013. Pecados originales, Barcelona: Anagrama.

Fernández López, Juan Antonio. 2009. "Funcionamiento y discapacidad: la clasificación internacional del funcionamiento (CIF)", en: Revista Española de Salud Pública 83 (6): 775-783.

Jacobs, Helmut. 1999. "Entrevista con Rafael Chirbes", en: Iberoamericana 23 (3-4): 182-187.

Labrador Méndez, Germán. 2014. "En la orilla, de Rafael Chirbes: proteínas y memoria”, en: Turia: Revista Cultural 112: 225-234.

López Merino, José Manuel. 2005. "Calas en La caída de Madrid", en: Tonos digital: Revista Electrónica de Estudios Filológicos, https://www.um.es/ tonosdigital/znum10/estudios/M-Lopez.htm [04-11-2019].

Mitchell, David/Snyder, Sharon. 2000. Narrative prosthesis. Disability and the Dependencies of discourse, Ann Arbor: The University of Michigan Press.

Robledo Martín, J. et al. 2017. "La externalización del cuidado de personas mayores a mujeres migrantes: quién decide y en qué circunstancias", en: SIPS: Pedagogía Social. Revista Interuniversitaria 29: 183-196.

Romañach Cabrero, Javier. 2010. "Lenguaje y cultura: la percepción social de la diversidad funcional (discapacidad)", en: Libre Pensamiento 66: 28-33.

Romañach Cabrero, Javier/Lobato, Manuel. 2007. “Diversidad funcional”, en: Lois Álvarez/José Villanueva et al. (coords.), Comunicación y discapacidades: actas do Foro Internacional, Pontevedra: Colexio Profesional de Xornalistas de Galicia/Observatorio Galego dos Medios: 321-330.

Romañach Cabrero, Javier/Palacios Rizzo, Agustina. 2006. El modelo de la diversidad: la Bioética y los Derechos Humanos como herramientas para alcanzar la plena dignidad en la diversidad funcional, Madrid: Ediciones Diversitas-AIES.

Sobejano, Gonzalo. 1988. "La novela ensimismada (1980-1985)", en: España Contemporánea: Revista de Literatura y Cultura 1 (1): 9-26.

Spivak, Gayatri. 1988. In Other Worlds: Essays in Cultural Politics, London/ New York: Routledge. 



\title{
Alejandro F. Gasel \\ Universidad Nacional de la Patagonia Austral \\ Posiciones de los sujetos con discapacidad en la narrativa argentina reciente
}

\begin{abstract}
In this chapter I propose a study on the modes of treatment in the narrative programs of subjects with disabilities concentrating on current Argentine narratives. I conjecture that the imaginaries that circulate through the social discourses question the lexicon: "disca", "special angels", "different capacities". Likewise, a certain possible systematization is shown in the short history of Argentine literature regarding these subjects in order to immediately put in evidence how the imaginations about disabilities currently operate, understood as the category of positions in the Spanish narrative (Fumis 2019) based on Aurora Venturini's Las primas, Silvia Molloy's Desarticulaciones, and Leonor Silvestri’s Games of Crohn.

In search of showing the situation in other fields, reference is made to the advances in two fields: legal and educational, which promote and produce imaginaries about disability insofar as they corroborate a certain perceptual system by entering concomitantly with the literary field. There is an interest in different fields to stop the moral judgments emanating from capacitist devices present in social discourses. The bet is to recognize that the work of literary discourse has greater density in its enunciative mortar.
\end{abstract}

Keywords: current Argentine narrative, positions, assimilation and impugnation

\section{Introducción}

Hace más de diez años que trabajo en un Profesorado de Educación Especial enseñando Lengua, Literatura y su correspondiente didáctica. Durante mucho tiempo, intuía que los estudios literarios tenían mucho para aportar a la formación de esos futuros profesionales que trabajarían en diferentes niveles del sistema educativo argentino donde la educación especial se conforma como una modalidad ${ }^{1}$.

1 La Ley de Educación Nacional 26.206 en su artículo 17 señala que son ocho las modalidades del sistema educativo, aquellas opciones organizativas y/o curriculares de la educación común, dentro de uno o más niveles educativos, que procuran dar respuesta a requerimientos específicos de formación y atender particularidades de carácter permanente o temporal, personales y/o contextuales, con el propósito de garantizar la igualdad en el derecho a la educación y cumplir con las exigencias legales, técnicas y pedagógicas de los diferentes niveles educativos. Asimismo, la resolución 155/11 del Consejo Federal de Educación define que la modalidad especial tendrá como objetivo 
No obstante, tuvo que pasar mucho tiempo (reformas curriculares del profesorado incluidas) para que pueda tener una cabal lectura para resolver el enigma: desde dónde los estudios literarios podrían realizar aportes a dichas profesionales (en su mayoría mujeres jóvenes de clase popular).

En este sentido, el artículo siguiente nos muestra el estado de los imaginarios sobre la discapacidad en tres campos posibles: a) el campo jurídico b) el campo de las teorías educativas y c) el campo literario.

Para analizar el estado en el campo literario, se opera con el concepto de posiciones del sujeto con discapacidad ${ }^{2}$ que es una reapropiación de los usos que Daniela Fumis (2019) realiza cuando estudia la posición de la infancia en la narrativa española contemporánea. En este punto del análisis literario, nos interesa subrayar el pasaje de una posición del sujeto con discapacidad que es narrado/hablado hacia otro que enuncia y resemantiza una discapacidad sin condiciones. En este aspecto, leemos a Horacio Quiroga, Roberto Arlt, Sylvia Molloy, Aurora Venturini y Leonor Silvestri.

En síntesis, retomo el concepto de un sistema perceptual (Copes 2014) para dar cuenta de transformaciones en la contemporaneidad argentina de las posiciones del sujeto con discapacidad, haciendo foco en la narrativa literaria.

\section{De cómo varios campos confabulan}

Este apartado aborda dos campos que coexisten con la actual producción de la literatura argentina: el campo educativo y el campo jurídico. En este marco, intento señalar como la productividad de ambos sistemas vienen a construir imaginarios más o menos estables sobre la discapacidad que, al menos, no pueden obviarse a la hora de pensar la literatura.

brindar a las personas con discapacidad, temporales o permanentes, una propuesta pedagógica que permita el máximo desarrollo de sus posibilidades, la integración y el pleno ejercicio de sus derechos.

2 He preferido el uso de la expresión sujeto con discapacidad por recomendaciones de colegas (ante mi primera opción que era diversidad funcional), las razones que sostengo es que es la expresión que se acepta a partir de la incorporación de la Convención Internacional de los derechos de las personas con discapacidad y, sumado a esto, es el uso léxico más estándar y común que se asume en diferentes documentos curriculares, resoluciones y normativas varias de la modalidad, tanto las que emanan del Estado Nacional como las jurisdicciones provinciales en Argentina. El uso de sujeto con discapacidad es lo que garantiza y me genera confianza. No obstante, aceptamos que el término no es estático sino dinámico y que su uso no debe entenderse como un límite sino como una potencia liberadora de nuevas afectaciones y el fin de tanto silenciamiento y discriminación. 
El campo educativo en Argentina tiene como referente a las producciones teóricas de Carlos Skliar, Silvia Dustchasky e Inés Dussel que han compartido una lectura cuya presencia es visible en documentos curriculares y bibliografía de formación posgradual, poniendo en crisis los paradigmas biologicistas que han venido constituyéndose como centrales en la mayoría de los enfoques de enseñanza en cualquiera de los niveles educativos: inicial, primaria, secundaria y superior.

Carlos Skliar ${ }^{3}$ viene argumentando desde diferentes posturas dentro del campo académico y científico de diversas formas, ya en el 2005 nos invitaba a pensar que un camino posible y bastante lógico era entender que las prácticas educativas debían tratar de poner en tela de juicio el concepto de normalidad y no el de anormalidad. Argumentaba que tres son los fundamentos de la escuela: a) completud b) de futuro y c) lógica de explicación y comprensión. La idea de completud sostiene que la escuela está allí pues algo debe, puede y merece ser completado. Asume que la imagen tradicional de la infancia y/o de la juventud como algo incompleto, como algo que aún no es, como algo que no es en sí misma, en este marco, entiende a la alteridad deficiente como algo incompleto, como algo que aún no es, como algo que no es en sí misma (sino por medio de una burda y obstinada comparación con aquello que se piensa como normal); si mirásemos a los niños y niñas de clases populares, o a los jóvenes, o a los indios, o a las mujeres, o al extranjero, entre muchas otras figuras de alteridad, todas ellas como incompletudes, entonces, el argumento de la completud es aquello que sirve para argumentar para qué sirve la escuela: sirve para completar al otro, sirve para completar lo otro. El otro argumento es de futuro en la educación: todo lo que el otro está siendo en este momento no es sino un pretexto, muchas veces insoportable, para alguna otra cosa que el otro deberá ser en el futuro por obra y gracia de la educación. Y, en tercer lugar, un argumento de una lógica de explicación (de los maestros y maestras) y de comprensión (de los alumnos y alumnas).

3 Quiero destacar dos posiciones de este agente social que no pueden entenderse como estultas. En primer lugar, su lugar en FLACSO Argentina como coordinador de los siguientes posgrados: posgrado Pedagogías de las diferencias, Escrituras: creatividad humana y comunicación (junto a Violeta Serrano García), Entre cuerpos y miradas (junto a Iván Castiblanco Ramírez) y Despatologizando diferencias (junto a Gisela Unglitoglich y Juan Vasen). Asimismo, es Investigador Principal en el Consejo Nacional de Investigaciones Científicas en las áreas Psicología, Ciencias de la Educación y Filosofía bajo el tema Entre infancias, pedagogías y literatura. Ver: https://www.conicet. gov.ar/new_scp/detalle.php?keywords=\&id=20818\&datos_academicos=yes 
En este sentido, retoma a Jacque Ranciére (Larrosa 2003, Skliar 2001) para sostener que la explicación no es más que la invención y la construcción constitutiva de la incapacidad del otro. Se explica, pues se ha creado antes un incapaz que necesita de la explicación. La invención -y la construcción y la producción - de la incapacidad del otro es aquello que posibilita el nacimiento de la figura del explicador. Y justamente es el maestro, la maestra, el explicador que ha inventado al incapaz para justificar su explicación.

En este contexto de razonamiento teórico, Carlos Skliar piensa que la llamada educación especial más que de una cuestión de paradigmas se trata de una verdadera disputa sobre "la perpetuación o la implosión de aquello que llamamos de educación especial "tradicional" es decir:

Más específicamente, me parece que habría que considerar la existencia de una frontera que separa de modo muy nítido aquellas miradas que continúan pensando que el problema está en la "anormalidad" de aquellas que hacen lo contrario, es decir, que consideran la "normalidad" el problema. Las primeras - sólo en apariencia más científicas, más académicas - siguen obsesivas por aquello que es pensado y producido como "anormal", vigilando cada uno de los desvíos, describiendo cada detalle de lo patológico, cada vestigio de anormalidad y sospechando de toda deficiencia.

[...] Estas miradas, entonces, podrían socavar esa pretensión altiva de la normalización que no es más que la imposición de una supuesta identidad única, ficticia y sin fisuras de aquello que es pensado como lo "normal". Por eso creo que la educación especial podría ser pensada como un discurso y una práctica que torna problemática e incluso insostenible - y más bien imposible - la idea de lo "normal" corporal, lo "normal" de la lengua, lo "normal" del aprendizaje, lo "normal" de la sexualidad, lo "normal" del comportamiento, etc., acercándose de ese modo a otras líneas de estudio en educación, como lo son los estudios de género, los estudios culturales, el posestructuralismo, la filosofía de la diferencia. Si aquello que llamamos de educación especial no sirve para poner en tela de juicio "la norma", "lo normal", "la normalidad", pues entonces no tiene razón de ser ni mayor sentido su sobrevivencia. (Skliar 2004: 10)

En este marco, apelando a las construcciones de la escuela argentina y sus importaciones, Inés Dussel ${ }^{4}$ se interroga sobre los usos de la expresión atender a la diversidad y lo que significa sus demandas. Conceptualiza que en esta coyuntura la "atención a la diversidad" asume un lugar privilegiado en las políticas educativas, que desde mediados de los noventa en Argentina se ejecutan con la premisa de atender a la pluralidad, combinando la focalización de las prestaciones con ecos del discurso multicultural que proclama la celebración de las diferencias. Lo llamativo es para la autora que las medidas tomadas por las políticas argentinas

4 Investigadora en Educación en la Universidad de San Andrés y parte del staff docente de la FLACSO sede argentina donde es investigadora Principal del área Educación. 
no interrogaron las condiciones institucionales y sociales que producen la exclusión ni se propusieron exceder la forma de la caridad prepolítica o del clientelismo. Sostiene la autora que:

La "atención a la diversidad" se volvió muchas veces un eufemismo de la educación para los pobres, de la distribución compensatoria de recursos en un contexto de desigualdad que se dio por sentado. Ello se evidencia en los sentidos sobre la diversidad que hoy circulan entre los docentes. Ésta es leída, por muchos de ellos, como un indicador de extrema pobreza o de discapacidad manifiesta; no engloba a la diferencia inscripta en cada uno de los seres humanos, sino que remite a la desigualdad total sobre la que hay poco por hacer. "Yo sí que trabajo con alumnos diversos", se escucha en los cursos de capacitación cuando se comienza a trabajar el tema, y allí inevitablemente surgen relatos terribles y dolorosos. (Dussel: 2004: 8)

La perspectiva de Silvia Duschatzky $(2007,2011)$ no abona directamente al tema de la discapacidad, pero su producción teórica se encuentra en los fundamentos curriculares de los Profesorados de Educación Especial del país, como así también en las recomendaciones curriculares para la confección de los mismos realizado por el Instituto Nacional de Formación Docente 6 . A partir de sostener que la literatura pedagógica, es la que menos permite iluminar los tiempos recientes de la escuela, Silvia Duschatzky (2011) piensa la escuela como un territorio para la investigación de un poder social antes que un escenario que debe realizar una serie de prescripciones. Para construir este entramado nuevo, la categoría que potencia pasiones se llama en el programa de duschatzkyano "no escolar", dicha conceptualización permitió pensar cosas que muchas veces la escuela o no ve o, si ve, interpreta, clasifica y finalmente rechaza. Entonces donde la escuela dice "ADD" [N: síndrome de déficit de atención] o dice "violencia". Para la economía duschatzkyana, eso mismo que la escuela, la psicología y la pedagogía muchas

5 Profesora de FLACSO Argentina y directora general del posgradosobre Gestión Educativa. Sus trabajos con equipos directivos permiten también ver los impactos que tiene su producción teórica en el campo educativo argentino. Sus lecturas se reconocen con raíces Deleuzianas, Guattarianas que son utilizados como formas de pensar lo que la autora denomina lo no escolar.

6 El INFOD es un organismo nacional, dependiente del Ministerio de Educación que regula la mayoría de los Profesorados encargados de la formación inicial: Profesorado para el Nivel Primario, para el Nivel Inicial y para la modalidad Especial. Este organismo editó una serie de recomendaciones para el armado de los profesorados (2009) que centra su atención en el pasaje de un paradigma regulado por los postulados biologicistas hacia otro regulado por una perspectiva cultural y centrado en una pedagogía de las diferencias. 
veces piensan desde conceptos preconstruidos tiene una forma deshilachada y se convierte en una materia de investigación. Lo no escolar también es la tutora que le responde a la piba: "yo te veo actriz". No es que lo no escolar está solamente en los pibes, o que lo no escolar es lo que no puede estar en la escuela o a lo que se enfrenta la escuela. Es una materia, en principio, inorgánica y que puede disparar posibles, si conecta con un pensamiento que no es ni el de la clasificación ni el del rechazo. Diría, también, que lo escolar está en el plano de la retórica y lo no escolar está en el plano de la existencia.

Finalmente, estos tres autores recortados ponen en discusión en el campo teórico educativo de argentina una mirada excéntrica respecto al tradicional modo de hacer "educación especial". Los autores, apelando a una arquitectura teórica compleja (posestructuralismo francés, sociología, psicoanálisis, filosofía spinoziana) configuran un campo educativo con avances acreditables en función de cuestionar un paradigma exclusionista de los sujetos con discapacidad.

Asimismo, en el campo jurídico también se evidencia un espacio ganado contra una perspectiva exclusionista. En efecto, Argentina tiene una configuración de orden constitucional y tratados anexos que nos permiten reconocer un avance. En líneas generales, se asume que sobre la democracia entendida como forma de vida que implica el compromiso de un estado de derecho, de darle contenido sustancial a través de la definición y sistematización de políticas por parte de sus gobernantes. En este marco, señalo como punto de partida la Constitución Nacional que en sus artículos 14, 16, 28, 31, 33, 42, 43 y 75 inciso 18 , determinan los principios en los que se basa la atención integral a sujetos con discapacidad. Estos artículos delinean las notas características de la atención integral de nuestro país: el federalismo, la libertad de enseñar y aprender; la participación y el pluralismo; la unidad y la apertura.

En este marco, la Ley de Educación Nacional N. ${ }^{\circ} 26.206$ (LEN) y en consonancia con ella, regula el ejercicio del derecho de enseñar y aprender consagrado por el artículo 14 de la Constitución Nacional y de los tratados internacionales incorporados a ella. Determina que la educación y el conocimiento son un bien público, un derecho personal y social garantizado por el Estado para construir una sociedad justa, reafirmar la soberanía e identidad nacional, profundizar el ejercicio de la ciudadanía democrática, respetar los derechos humanos y libertades fundamentales y lograr el fortalecimiento del desarrollo económico-social de la Nación. Asimismo, que el Estado-nación suscriba la Convención Americana de Derechos Humanos, Declaración Universal de Derechos Humanos, Convención de Derechos Humanos, Convención de Derechos de Personas con Discapacidad y su protocolo facultativo (Ley 26.378), Convención de Derechos del Niño, Pacto Internacional de Derechos Económicos, Sociales y Culturales 
concibe un sujeto de derecho que desplaza del lugar deficitario al sujeto con discapacidad. En el marco nacional, poder reconocer las siguientes leyes como: Ley 22.431 Sistema Integral de Protección de Personas con Discapacidad, Ley 24.901 Sistema de Prestaciones básicas de habilitación y rehabilitación de personas con discapacidad, Ley 23.592 Actos discriminatorios. Medidas para quienes impidan el ejercicio de derechos y garantías constitucionales, Ley 25.504 Certificado Único de Discapacidad, Ley 23.660 Ley de Obras Sociales, Ley 23.661 Creación de Sistema Nacional del Sistema de Salud, Ley 26.657 Nacional de Salud Mental, a las que se le puede adosar las leyes provinciales concordantes que se encuentran en la misma tónica.

Ahora bien, ¿significa esto que en el campo educativo y jurídico argentino ya está todo hecho por los sujetos con discapacidad? Bajo ningún motivo afirmo esto, solo intento describir someramente los aspectos en dos campos que discursivizan sobre la discapacidad y dan garantía. Nada impide que la discriminación y la subestimación de la discapacidad siga existiendo y, en especial, como un juicio moral que se constituye en el par sano/insano, normal/anormal.

Es por ello, que el estudio de la literatura como entramado supercomplejo, discursivo no posibilita acceder a otra perspectiva sobre la discapacidad que alejada de la posición de "reflejar" lo que la sociedad dice, "mostrar" lo que se concibe como discapacidad, elabora una textualidad capaz de detener los juicio morales y moralizantes sobre los sujetos con discapacidad que son objetos de este trabajo. ¿Cuáles son esos textos? ¿Cómo funcionan? ¿Qué efectos de sentidos constituyen? Exploraré lo mismo en el apartado siguiente.

\section{Narrar la discapacidad en la literatura argentina reciente}

Me detengo en la narrativa argentina para poder analizar un tipo particular de narración, aquella que en su programa narrativo devela algo concebido como una otredad inenarrable. No pretendo en este apartado enumerar exhaustivamente las veces que un discapacitado aparece en la literatura argentina y, a partir de ahí, establecer una tipología más o menos estable, más o menos aplicable. Quiero solo trazar un itinerario posible dentro del sistema literario de la literatura del Río de la Plata que nos muestra un movimiento discursivo particular y excepcional que puede ser catalogado como un pasaje de "la representación monstruosa" como mímica o temor hacia lo otro, hacia la operatividad de "una posición del sujeto con discapacidad" que como tal impugna/aniquila y desmonta la representación monstruosa que no solo es registrable en un corpus literario sino también en el habla cotidiana a través de un conjunto léxico similar a: "el disca", "el down", "el corki", "angelitos especiales", "capacidades diferentes", etc. 
Cuando conceptualizo "posición del sujeto con discapacidad" me refiero a una re-elaboración de la categoría que Didi-Huberman (2008) llamó posición infantil en modo de posiciones excéntricas. Me interesa el uso que Daniela Fumis (2019) para estudiar programas narrativos, en su caso, posición de infancia le otorga la posibilidad de razonar tres narradores españoles contemporáneo (Millás, Rivas, Mendicutti) y, de este modo, me advierte de su productividad para el estudio de los programas narrativos recientes. Estas posiciones problematizan los lugares establecidos en función de exponer una falta. Entenderemos a las posiciones de la discapacidad como un espacio de investigación, un territorio que se ha convertido en un emplazamiento (Foucault 2010) un lugar donde es posible habitar para desautomatizar el discurso capacitista que mide en términos de utilidad al cuerpo discapacitado. Pretendo leer a los sujetos discapacitados como potencia libre, creadora y alegre y no desde el déficit.

Para mostrar la representación del déficit, la falta que significa "una representación monstruosa" dos textos literarios del Río de la Plata se me presentan como ejemplares: "La gallina degollada" de Horacio Quiroga (1993 [1917]) y "El Jorobadito" de Roberto Arlt (2003 [1933]). Para dar cuenta de estas "posiciones del sujeto con discapacidad" apelaré a Desarticulaciones de Sylvia Molloy (2010), Las primas de Aurora Venturini (2014) y Games of Crohn de Leonor Silvestri (2017).

Considero que la escritura de "La gallina degollada" entrama variantes controversiales sobre la discapacidad en su proceso narrativo. El narrador nos cuenta sobre el nacimiento de unos niños y su desestabilización de la normalidad que se repite en cuatro ocasiones; hasta que al final, el nacimiento en la familia de una niña retoma otro curso que no es el de la enfermedad discapacitante (presumiblemente meningitis) que afecta a los hijos del matrimonio Manzini-Ferraz. El narrador describe un espacio propio de los niños: el patio y una conducta que es enigma y resolución de conflicto: la imitación. En efecto, la conducta imitativa que ofrecen aquellos que son nombrados como "idiotas" termina con un crimen atroz que cometen los incapaces: degollar a su hermana. La variable discapacitante de los sujetos es narrada aquí a partir de un orden pedagógico que supone un mensaje de cuidado y atención a las familias. Inevitablemente, el narrador fabula una novela familiar cuyo impacto resolutivo quiere darnos una lección de cierto higienismo y moralidad en la conformación de la pareja en un tono ideológico presente en la época (principios de siglo XX). Similar a esta línea de lectura, el estudio de Gustavo Pis Diez (2000) propone leer la construcción metafórica de la enfermedad "como una fatalidad que preside la vida de sus personajes".

En este marco, en El jorabadito (1933) de Roberto Arlt, nos muestra un narrador que constituye una diatriba contra un sujeto asimilado en su relato como 
un anormal. Rigoletto es el sujeto de narración, amonestado en el relato como deforme y monstruoso por un narrador que lo dice desde la cárcel donde se encuentra por haberlo estrangulado. Por supuesto que la caracterización de este sujeto es calificada en términos variopintos. En algunos momentos, es alguien cómico y ocurrente que despliega su verborragia con matices lexicales lunfardos e hiperbólicos, pero en otras situaciones narrativas, Rigoletto es todo lo que deberíamos odiar. Un enunciado cuyo este exterminio es anunciado desde el inicio. No obstante, en la narración existe una tematización que objetiviza y nos distancia de Rigoletto. El relato es un caso ejemplar de la imaginación literaria del exterminio como lo conceptúa Gabriel Giorgi (2004) en torno a la constitución de la homosexualidad argentina, pero en este caso, para los sujetos concebidos bajo el léxico de deformes, monstruoso. En efecto, Gabriel Giorgi estudia cómo la homosexualidad ha ofrecido al imaginario una galería de cuerpos terminales: cuerpos donde cierran relatos e historias colectivas, donde se cancelan. El narrador testigo, rector de El Jorabadito repone este relato de exterminio y configura un cuerpo discapacitado pronto a extinguirse.

No obstante, existen un conjunto de textualidades narrativas que señalan un cambio en el sistema perceptual ${ }^{7}$ en relación con las corporeidades discapacitadas. Un conjunto que se constituye en la literatura ${ }^{8}$, el cine ${ }^{9}$ y las series de

7 Uso esta palabra en el sentido que lo usan los profesores de Literatura Argentina, Guillermo Canteros y Ana Copes (2014), para dar cuenta de las regulaciones y dispositivos que la Modernidad han realizado. En este marco, retoman a Walter Benjamin cuando nos explica la Modernidad en la percepción y en el uso, a diferencia de las explicaciones sociológicas centradas en cambios institucionales o de la Escuela de Frankfurt por cambios estéticos. Donald Lowe conceptualiza la idea de campo perceptual en el marco de su Historia de la percepción burguesa (1986). Me interesa este uso porque nos substrae de una perspectiva psicológica sociológica, pudiendo apelar a la conformación de la modernidad-mundo para el contexto argentino.

8 Acepto que esta serie literaria centrada en la narrativa argentina puede ampliarse más significativamente, pudiendo sumar a la misma: Ese manco Paz de Andres Rivera (2003), el capítulo de María Moreno (2007) "En familia" que se encuentra en el libro Banco a la sombra y el cuento de Samanta Schweblin Pájaros en la boca que se encuentra en el libro homónimo. En próximos trabajos pretendo ahondar en ellos, para este me he limitado a este corpus a fin de visualizar cómo funcionan mis conjeturas.

9 La película de Albertina Carri La rabia que analizó en Dr. Christian von Tschilschke, a la cual podemos sumar la ficcionalización de una enfermedad discapacitante como se relata en Un año sin amor de Anahía Berneri (2005) y el cortometraje en estilo road movie Las mil millas de Luca que repone un viaje de padre e hijo con síndrome de down que viajan a la Patagonia para realizar el tour mil millas, cuyo realizador y protagonista es Pablo Poncini (2019). Asimismo, podríamos sumar el corto del guionista 
televisión ${ }^{10}$ en Argentina y entran en concomitancia con los cambios de posición del sujeto discapacitado de ser hablado a poder narrar. Particularmente en este trabajo, nos interesan las escrituras de Las Primas de Aurora Venturini (2014), Games of Crohn de Leonor Silvestri (2017) y Desarticulaciones Sylvia Molloy (2010).

En efecto, la construcción enunciativa que podemos reconocer en Desarticulaciones nos pone en un nuevo sistema perceptual donde el sujeto con discapacidad tiene voz que nos permite entonces, escuchar su configuración del mundo, sus valoraciones, usos lexicales. El texto de Sylvia Molloy aborda la historia de ML a quien el avance del Alzheimer va tomando su habla y cuerpo día y a día. El trabajo de la enfermedad va desalojando los recuerdos de ML, pero a la vez, va prefigurando otra enunciación y subjetividad posible. El texto no hace hincapié en el déficit o quiebre corpóreo de una enfermedad que discapacite, sino que insiste en poner en evidencia las nuevas secuencias que el lenguaje prefigura $y$, en este marco, la nueva subjetivación de ML.

En este marco, la narradora visita o telefonea a ML a quien la une una estrecha relación de corte cómplice en temas intelectuales y lingüísticos, a partir de esas visitas y esos cruces va poniendo de manifiesto cómo el borramiento del recuerdo permite la construcción de otro sujeto cuyo poder perlocutivo sobre

Campanella llamado Ian (2018) donde se figura en una animación los deseos de un niño con parálisis cerebral que quiere hacer amigos.

10 Entre las series de televisión, considero importante destacar Jorge de Malena Pichot que se emitió originalmente en el 2013 por la TV Pública y financiada por el Instituto Nacional de Cine y Arte de Argentina, el Ministerio de Planificación Federal y el de Desarrollo Social. Jorge Peker es un abogado frustrado que no ejerce su profesión y es empleado en un call center. El conflicto aparece cuando se da cuenta de que no puede mantener esta inmensa casa solo, lo que lo obliga a alquilar un cuarto y el único candidato que se presenta es Ludovico, un chico vivaz, activo y emprendedor, su completo opuesto. Ludo es paralítico y anda en silla de ruedas. Esto hace que Jorge luche contra sus prejuicios y aprenda a vivir, no con alguien diferente, sino, sencillamente, a vivir con alguien, a aceptar al otro y a considerarlo. Y así emprende el camino real para poder formar la familia que siempre deseó. En el mismo contexto, TV por la inclusión dirigido y producido por Claudia Villarroel y Bernarda Llorente se emitió durante el 2011 por el canal de aire 9 donde en dos capítulos se aborda la cuestión de los sujetos con discapacidad. Sin coberturas (episodio 9) aborda cómo una prepaga u obra social intenta dejar sin atención médica general a una niña con síndrome de down https:// www.youtube.com/watch?v=qDyFz6Z6MVI y el episodio 12 Sin pertenecer donde se relata la historia de un hombre que se discapacita y termina en silla de ruedas, hecho que lo hace enfrentar una serie de nuevos desafíos. Esa serie tuvo un reconocimiento a través de una premiación internacional. 
los otros conmueve y atemorice porque el olvido oculta o deforma recuerdos estructurantes de la amistad. La narración de una ruina y afectación de la enfermedad discapacitante es la oportunidad que la narradora encuentra para potenciar las reflexiones sobre la palabra, el recuerdo y el olvido. ML no instituye la enfermedad discapacitante sino la potencia de poder pensar qué es el olvido, qué es recordar y cuál es la posibilidad de la amistad en tiempos de ruinas del recuerdo.

¿Cómo dice yo el que no recuerda, cuál es el lugar de su enunciación cuando se ha destejido la memoria? Me cuentan que la última vez que la llevaron al hospital le preguntaron cómo se llamaba y dijo Petra. Una persona que estaba con ella vio la respuesta como un signo de que todavía era capaz de ironía, se indignó ante las pocas luces del médico que no entendió nada. Pienso: si es que hay ironía y no mero deseo de creerla capaz de ironía, se trata de una de esas ironías que llaman tristes. ¿Petra, piedra, insensible, para describir quién es? (Molloy 2010: 19)

La pregunta sobre la actualidad y posibilidad de recordar de ML y su impacto o afectación es la tematización que nos permite salir del déficit con lo cual se ha imaginado al cuerpo discapacitado y dar lugar a una posición del discapacitado donde es capaz de entramarse en la productividad literaria. Ficcionalizar a ML, tematizarla es ficcionalizar los procedimientos ordenadores de la nouvelle de Molloy y su centro operacional del programa narrativo. En este mismo contexto de narrativas argentinas, la aparición de una novela como Las Primas pone de manifiesto en la organización enunciada del relato, la relación entre primas discapacitadas. De hecho, una discapacitada es la narradora que cuenta su vida. Cómo sabemos, narrar es ordenar y predisponer un mundo discursivo capaz de desestabilizar las esclerosadas representaciones.

Contextualizada en la década de 1940, Las primas es el retrato y relato de una familia disfuncional y quebrada, conformada por seres grotescos, deformes y dañados. Las mujeres que conforman este linaje se caracterizan por lidiar a diario con la miseria y la desgracia, limitadas por sus fallas y carencias, físicas o afectivas. Está narrada en primera persona por Yuna, una niña abandonada por su padre, rechazada por su madre y su tía virgen, encargada de cuidar a su monstruosa hermana deficiente mientras va descubriendo su talento para pintar, el cual le permite expresar parte de ese caos que lleva dentro, tal vez lo único que sepa hacer bien. Yuna contará con la ayuda de Petra, su prima, quien ordena su rol en el relato a partir de la traición, la sed de venganza y la animadversión contra el orden impuesto. La enana prostituta inconformista a la que le molesta ese rótulo de anormal al que la reduce la sociedad. Ella fungirá de guía en temas como el sexo y la muerte. Un apoyo (aunque nada confiable) para Yuna frente 
la racha de sepelios que padecerá la familia y la maldad de los hombres con los que tiene algún tipo de contacto. A lo largo de la novela, nos encontramos con abortos, asesinatos y perversas prácticas sexuales según el mundo lexical y valorativo que constituye la narradora. Una serie de hechos horrorosos evocados con inocencia y brutalidad, por igual.

En su argamasa enunciativa se narra el lado arisco de las cosas: aquello que incomoda y perturba. La voz se constituye en un tono enunciativo donde Yuna alterna entre lo lúdico, lo sórdido y lo triste, saliendo a flote en un escenario lleno de excrementos y deformidades, de hostilidad filial y locura. Una lucha constante que se plasma incluso en el momento de la escritura. "A veces pienso que somos un sueño o pesadilla cumplida día a día que en cualquier momento ya no será, ya no aparecerá en la pantalla del alma para atormentarnos" (Venturini: 12). Para la narradora, contarnos y explicarnos qué es su vida se convierte en un deber, sin importar recurrir al diccionario la cantidad de veces que sea necesario con el fin de encontrar el vocablo preciso. Párrafos breves impregnados de humor negro, el lenguaje que utiliza la narradora busca cuestionar en todo momento las convenciones gramaticales, dejando traslucir la angustia y desesperación de la protagonista por revelarnos su historia percibiendo cada signo de puntuación como un obstáculo, un límite para narrar su verdad desnuda, cruda y sin complejos, pues como afirma: "si ponía punto o coma perdía la palabra hablada [...] me convenía comunicarme de viva voz rápidamente para que me entendieran y evitar lagunas silenciosas que descubrían mi incapacidad de comunicación verbal" (Venturini 2014: 54).

Cuando Yuna se autopercibe como discapacitada y narra desde ese locus es lo que constituye el gesto enunciativo que produce una excepcionalidad para la corta historia de la literatura argentina, dicho gesto ordena y sistematiza todos los tiempos, espacios y protagonistas de la historia novelada. Revela el relato un pasaje preponderante de ser narrado el sujeto discapacitado (ver lo referido a "La gallina degollada" de Horacio Quiroga o "El Jorobadito" de Roberto Arlt) a convertirse en el narrador. Ese pasaje permite que el cuerpo se institucionalice en la lengua, ordene los sentidos, jerarquizando tiempos y espacios, yuxtaponiendo historias, calificando acciones y elaborando un relato que da cuenta no solo de su discapacidad sino del trayecto utilizado para salvarse así misma de los órdenes biopolíticos establecidos por el discurso social.

El cuerpo institucionalizado que analizo no es un cuerpo reconstruido por instituciones tradicionales, con pautas esclerosadas sino de una institucionalización corpórea posible en el devenir mundo de un cuerpo que no encaja según los órdenes prescriptos por los órdenes dominantes del discurso social. Por ende, es un cuerpo que asiste a una escuela especial, con profesores especiales, en turnos 
especiales, cosa que no se olvide nunca que su condición de "especial" significa una diferencia inigualable para la sociedad que vivimos. Sin embargo, Yuna en tanto cuerpo institucionalizado encuentra un hueco/intersticio en ese discurso y deviene como profesora de arte en una escuela. Deviene lo que es, un sujeto. Eso es lo que puede la literatura argentina con esas corporeidades relegadas del discurso oficial.

Finalmente, me interesa no obviar a Leonor Silvestre y su texto Game of Crohn. Leonor Silvestre nos convoca poderosamente la atención a quienes nos preocupa los problemas del género/corporeidad y sexuación (la expresión se la debo al psicoanalista brasileño Oscar Reymundo), especialmente si el trabajo se realiza en los bordes disciplinarios, para el caso de nuestras investigaciones ${ }^{11}$, que estudia la corporeidad en el marco de las artes y las culturas recientes. Me importa Leonor por los usos de su cuerpo que despliega en cada aparición pública: entrevistas, performance, clases o conferencias que se pueden visualizar en youtube, así como también posiciones teóricas que las fue desarrollando en diferentes publicaciones. Leonor ${ }^{12}$ se presenta como una sobreviviente al feminismo de la corrección política y a la judicialización LGTBQI, no obstante, también sobrevivió a dispositivos necropolíticos del capacitismo a los cuales se enfrenta cuando se despierta Crohn.

Elegí leer su texto narrativo a partir de la pregunta ¿qué cuerpos defiende Leonor? Con la intención de resaltar la intención generada en su escritura de potencia y afectación y alejarme del relato testimonialista que suele encasillar lo autobiográfico.

En ese marco, iremos presentando una serie de conjeturas para pensar qué cuerpos defiende ${ }^{13}$ Leonor Silvestri a partir del libro Games of Crohn ${ }^{14}$. Cuando digo defiende, quiero decir, por un lado, que conceptualización corpórea queda

11 La mayoría de estas conjeturas forman parte de la producción del PI 29A/400, radicado en la Universidad Nacional de la Patagonia Austral cuya dirección está a cargo de la Dra. Marcela Arpes y lleva de título Arte y cultura: propuestas a partir del cuerpo.

12 Algunos de sus libros son La guerra en curso (Nos es nada, Paris, 2016), Guerra Fría (Germinal, Costa Rica 2014), El Don de Creer (Curcuma. 2010; Germinal, Costa Rica; Santa Muerte Cartonera México, 2009).

13 La palabra defensa también tiene otra connotación posible: Leonor se especializa en autodefensa y enseña a mujeres cis y trans las estrategias de la misma porque considera indispensable mantenerse a la retaguardia y al cuidado de las acechanzas del poder patriarcal que se denomina bajo la expresión machirulo.

14 Crohn designa el diagnóstico de una inusual condición autoinmune discapacitante que puede afectar el tracto intestinal, de la boca al recto. 
tematizada en su construcción discursiva: ¿cuáles son esos cuerpos acorralados según dispositivos de controles biopolíticos? ¿qué poder pueden ejercer los mismos? Y, en este sentido, qué es un discapacitado en las figuraciones discursivas de esta autora.

Una de las posiciones que asume la escritura de Leonor es detener los juicios moralizantes sobre los cuerpos y para ello centra la discusión sobre los usos "progresista" o de buena conciencia que se ejecutan desde el orden dominante sobre la discapacidad. La posición que Leonor asume como narradora insiste en describir y poner en evidencia los protocolos o dispositivos que se han convertido ciertos lenguajes de una diversidad funcional para el orden imperante. En este sentido, el discapacitado es convertido en un sujeto que se asimila en ese orden a partir de un uso léxico-semántico que finalmente, solo opera para continuar expulsándolo de manera ciertamente sofisticada del mismo orden que aparenta integrarlo. En este aspecto, la disputa semántica respecto a cómo nominar a la discapacidad: capacidades diferentes, capacidades especiales, ángeles especiales, son formas constituyentes de un dispositivo que Leonor llama capacitismo y que viene a convertirse en formaciones ficcionales de una normalización de cuerpos que vienen siendo desechados continuamente. Leonor añade a esto, que en otras formas ficcionales del mismo dispositivo: capacitismo lo constituye el matrimonio igualitario y los regímenes identitarios propuestos a partir de la identidad de género. Leonor ejemplifica diciendo: "quiero ver, escuchar ya sobre trans violadores, tortas femicidas, putos asesinos".

Una salida que debe caracterizar a aquellos cuerpos que traten de escapar a estos dispositivos los constituye la posibilidad que tienen los regímenes minoritarios de usar la ironía. Usar la ironía como arma para atacar, haciendo valer el humor queer que es el modo de reírse leerse/reconocerse y reírse de uno mismo. En su caso, Leonor imagina su cuerpo como discapacitado a partir de la enfermedad de Crohn, hace referencia que cuando la enfermedad despierta no puede estornudar porque inmediatamente se hace encima (y no justamente pis). En efecto, Games of Crohn asume en primera persona los registros de un diario que experimenta a través de la escritura el proceso discapacitante a que la subsume Crohn y que le permite a esa primera persona que enuncia su crisis y reapertura al don del mundo, tomar conciencia de aquellos dispositivos que se hacen presentes y construyen murallas o barreras, es decir, presentifican la discapacidad que acecha la potencia de ese cuerpo enunciador. Narrar dentro y fuera de un hospital es la huella desautomatizante de un texto que deshace géneros mientras deshace morales. Dice Leonor "mi vida se ha convertido en una sucesión interrumpida de médicos, tratamientos, estudios, trámites y discusiones con personal técnico y administrativo". Aunque el final es el contrapunteo contra las 
morales imperantes "no es una enfermedad la que tengo" (Silvestri 2017: 157) lo que da inicio a la escritura literaria que impugna los discursos estables sobre la normalidad.

Recapitulo: la discapacidad sin condiciones constituye un modo que defiende Leonor Silvestri. En este sentido, mi lectura razona que es viable reconocer una figuración posible corpórea que se repite consistentemente en todas sus intervenciones públicas, donde el cuerpo que importa es un cuerpo atávico, primigenio sin ningún tipo de interferencia de la cultura. Porque cualquier interferencia sobre la corporeidad deviene siempre en una intervención de la cultura hetero capitalista sobre la misma y, por ende, la consiguiente organización de unas bios dominada por las regulaciones occidentales de la buena moral y la buena conciencia. Corporeidades no tuteladas por el Estado o intervenidos por las lógicas regulatorias de la sociedad capitalista: hombre/mujer, capacitado/discapacitado. El cuerpo defendido es un cuerpo que se mantiene en una posición de afuera de los mismos hábitos semióticos.

\section{Notas Finales}

En este trabajo he promovido pensar las posiciones del cuerpo discapacitado en la narrativa a partir de dos premisas: a) la primera es que hay diferentes campos que determina un sistema perceptual que enuncia un cambio de la voz del sujeto de discapacidad, donde dejar de ser hablado y comienza a pensar como quien habla, dice y, por ende, dicho en términos jurídicos, se autopercibe como sujeto de derechos. Para ello, he rastreado posiciones teóricas del campo educativo y jurídico y b) la segunda premisa, que ese cambio en el sistema perceptual se puede reconocer en la narración literaria donde se puede leer esta voz constituida como rectora y organizadora del decir contemporáneo. Un sujeto discursivo que organiza y valora el mundo desde su perspectiva. Para ello, reviso textos de Horacio Quiroga, Roberto Arlt, Aurora Venturini, Sylvia Molloy y Leonor Silvestri. Este cambio enunciativo posibilita una serie de estrategias que:

- Realizan un pasaje de la tematización del sujeto excluido (Quiroga-Arlt) hacia una toma de voz y construcción de un nuevo ordenamiento de sentido. Es decir, el sujeto cuyo cuerpo es tipificado como discapacitado se considera ahora el regente de la voz y de los nuevos sentidos. Es así como ML, Yuna y Leonor se constituyen en voces disidentes y ostensibles.

- Configuración de alianza de excluidos: prostitutas, LGTBI, discapacitados como actores capaces de confrontar contra el discurso social capacitista y sus regulaciones. 
- Impugnación del lenguaje que se autoproclama inclusivo y sus dispositivos: feminismos blancos, profetas de la diversidad, escuelas especiales, etc.

- Desestabilización del concepto enfermedad y puesta en dominio de cuerpos otros.

Asimismo, el trabajo pretende continuar la línea de estudio sobre la relación cuerpo discapacitado y cuerpo enfermo en las narrativas recientes, como la posibilidad de ver en ellos no un producto biológico que interfiere los mecanismos del buen vivir sino como una regulación necropolítica que augura solo un estado posible a ser descartado.

\section{Agradecimientos}

A la Universidad Nacional de la Patagonia Austral por haberme autorizado la estancia en Alemania que me permitió el desarrollo en este trabajo. Asimismo, a la Universidad de Wuppertal y al Dr. Matei Chihaia que me alojaron y fueron una fuente de discusión y aprendizaje continuo. A la Dra. Susanne Hartwig y a su eficiente equipo que me hizo parte de su Congreso Internacional donde se me brindó la posibilidad de profundizar mis modos de pensar los problemas que vinculan literatura argentina y discapacidad. Al Consejo Provincial de Educación de la Provincia de Santa Cruz que también autorizó mi licencia por estudio en Alemania.

\section{Bibliografía}

Arlt, Roberto. 2003. El jorabadito y otros cuentos, Buenos Aires: Ediciones del Sur. Copes, Ana/Canteros, Guillermo. 2014. "Retóricas del espacio pampeano: transculturación y (deslecturas)", en: Crolla Adriana (ed.), Memoria cultural y territorialidad. Perspectivas comparadas desde la localidad, Santa Fe: Ediciones UNL: $101-108$.

Didi-Huberman, George. 2008. Cuando las imágenes toman posición. El ojo de la historia 1, Madrid: Antonio Machado libros.

Duschatzky, Silvia y otros. 2007. Maestros errantes, Buenos Aires: Paidós.

Duschatzky, Silvia y otros/Aguirre, Elina. 2011. Imágenes de lo no escolar, Buenos Aires: Paidós.

Dussel, Inés. 2004. "Escuela y diversidad. Un debate necesario", en: Revista Todavía N 8, Fundación Osde, Buenos Aires.

Foucault, Michel. 2010 "Espacios diferentes", en: Obras Esenciales, Madrid: Magnun: 1059-1068. 
Fumis, D. 2019. Ficciones de familia en tres narradores españoles contemporáneos: Millás, Mendicutti y Rivas, Santa Fe: Tesis doctoral.

Giorgi, Gabriel. 2004. Sueños de exterminio. Homosexualidad y representación en la literatura argentina contemporánea, Rosario: Beatriz Viterbo.

Larrosa, Jorge. 2003. Entre las lenguas. Lenguaje y educación después de babel, Barcelona: Laertes.

Molloy, Sylvia. 2010. Desarticulaciones, Buenos Aires: Eterna Cadencia.

Quiroga, Horacio. 1994. Cuentos de amor, de locura y de muerte, Buenos Aires: Espasa Calpe.

Skliar, Carlos. 2001. ¿Y si el otro no estuviera ahí?, Buenos Aires: Miño y Dávila.

Skliar, Carlos. 2005. "Poner en tela de juicio la normalidad, no la anormalidad. Políticas y faltas de políticas en relación con las diferencias en Educación.", en: Revista Educación y Pedagogía Vol. XII. N 41, Medellín: Universidad de Antioquia: 11-22.

Silvestri, Leonor. 2017. Games of Crohn, Buenos Aires: Queen Ludd.

Venturini, Aurora. 2014. Las primas, Buenos Aires: Random House. 

IV. Inclusión a través de una mirada diferente 



\title{
Christian von Tschilschke \\ Universität Münster
}

\section{La discapacidad como 'tenor' y 'vehículo' en La rabia de Albertina Carri}

\begin{abstract}
In the past years popular culture and mass media have increasingly focused on generating diversity. However, the relationship between minorities and majorities remains controversial. One contentious matter is the question, how the popularization of minority cultures with the large public should be evaluated. Starting from this general statement, the article develops two ways of aesthetic appropriation of disability based on Ivor Armstrong Richard's metaphor theory with its central terms 'tenor' and 'vehicle'. While 'tenor' refers to the representation of disability itself, 'vehicle' refers to the figurative or symbolic meaning that might be attributed to it. This distinction is applied to the analysis of the Argentine movie La rabia (2008), directed by Albertina Carri, a rural melodrama which describes - laconically and in a neorealist manner - the sexual entanglements and the violent conflicts between two dysfunctional families in the Argentine countryside. The film tells the story through the eyes of Nati, a six year old girl who suffers from an undiagnosed form of autism. It is shown in detail, how autism works on both semantic levels: as 'tenor' Nati's disability is represented authentically, as 'vehicle' it serves to convey the personal artistic vision of Albertina Carri as a typical author-filmmaker.
\end{abstract}

Keywords: Argentine cinema, cultural appropriation, disability studies, autism, Albertina Carri, La rabia

\section{La doble apropiación cultural de la discapacidad}

En su acepción más general, el problema básico de que se trata, en lo referente a la representación mediática de grupos tradicionalmente minoritarios y marginalizados, es el de saber, de negociar y de precisar quién puede hablar de qué, de qué manera y en qué condiciones. ${ }^{1}$ De hecho, con el éxito político y social de los paradigmas de la diversidad, interseccionalidad e inclusión, con la omnipresencia de todos los tipos de variedad de género, etnia o funcional posibles, $y$ con el auge de los estudios académicos de diversidad correspondientes, los queer studies, ethnic studies, disability studies y otros, en los últimos años la discusión

1 En su introducción al libro Autism and Representation (2008), también editado por él, Mark Osteen ya identifica la cuestión de "Who Speaks?" como central (2008b: 6-7). Véase igualmente a este respecto Hartwig (2018a: 7-8). 
pública acerca de la representación mediática de minorías y respecto a la relación entre mayorías y minorías se ha intensificado y diferenciado considerablemente, sobre todo en los EE.UU., pero también en otras partes del mundo. ${ }^{2}$ Tal como un crítico de cine alemán afirmó recientemente, uno no puede evitar la impresión de que hoy en día el cine ve su principal tarea en la producción y celebración de la diversidad. ${ }^{3}$ De hecho, basta pensar en la última obra de Guillermo del Toro mundialmente taquillera, The Shape of Water (2017), que reúne como protagonistas a Elisa, una joven limpiadora muda, a su compañera Zelda, una afroamericana, y al vecino de Elisa, Giles, un gay solitario y envejecido.

No obstante, este proceso no tarda en suscitar nuevos debates y sensibilidades en torno a la cuestión de si debe más bien ser interpretado bajo los aspectos positivos del reconocimiento - de aceptar algo como legítimo y darle visibilidad- y del aumento de la diversidad, o bajo el aspecto negativo de la 'apropiación cultural' de hacer culturalmente suyo algo que no le pertenece a uno, sino a otra cultura-. En su libro Who Owns Culture? Appropriation and Authenticity in American Law (2005) la jurista estadounidense Susan Scafidi estudió precisamente los conflictos de interés que surgen cuando asuntos relacionados con grupos minoritarios caen bajo la influencia de la cultura mayoritaria y se modelan según las reglas de los medios populares, los imperativos y límites del mainstream y las convenciones de la cultura de masas: "Far from an uncontested process, however, the movement of cultural products from subculture to public domain provokes both majority-minority struggles and fraternal conflict." (2005: 9). Si bien es verdad que los grupos minoritarios se benefician de cierto modo del interés que suscitan en la cultura mayoritaria, también es cierto que muy a menudo les parece que tienen motivo para quejarse de la imagen ignorante, inauténtica, distorsionada, simplificada, reductora, estereotipada o comodificada que esta difunde de ellos. ${ }^{4}$

Para subrayar el aspecto interseccional del tema, solo voy a poner dos ejemplos actuales, entre muchos, referentes a la representación cinematográfica de sexualidades y géneros no heteronormativos y de etnias minoritarias. Cuando en el año 2018 salió la película Girl, dirigida por el belga Lukas Dhont, sobre una chica transgénero de 15 años se le reprochó de inmediato de que el rol principal no fuera interpretado por un personaje transgénero. ${ }^{5} \mathrm{Y}$ cuando, en cambio, en

2 En cuanto a las conexiones entre disability studies, gender studies, sexuality studies y queer studies en el marco de una teoría de la interseccionalidad véase Fraser (2018: 9-12).

3 Cf. Stadelmaier (2018).

4 Sobre las objeciones que suscitó al respecto la representación de la tetraplejía en la película Mar adentro (2004) de Alejandro Amenábar, véase Tschilschke (2018a).

5 Cf., por ejemplo, Weidner (2018). 
la película chilena Una mujer fantástica (2017), de Sebastián Lelio, la cantante y actriz chilena transgénero Daniela Vega desempeñó, esta vez auténticamente, el papel de una joven mujer transgénero, el director fue criticado por incitar al voyeurismo. ${ }^{6}$

En cuanto a la representación cinematográfica de etnias minoritarias me limito a recordar el debate que provocó la superproducción estadounidense Black Panther (2018), dirigida por el afroamericano Ryan Coogler, a principios del año 2018 en los medios sociales y la esfera pública. El caso de este blockbuster muestra, de forma paradigmática, cómo la discusión sobre lo políticamente correcto tiene la tendencia de conducir a un regreso ad infinitum. Por un lado, la película se elogió por su elenco casi enteramente compuesto por actores afroamericanos, por otro lado, se veía acusado de saquear descaradamente el patrimonio cultural de África. ${ }^{7}$

Lo que se puede observar a la luz de estos ejemplos respecto a la representación de géneros y etnias marginalizados y excluidos, se comprueba fácilmente en el ámbito de la representación de la diversidad funcional donde los procesos y estructuras que están a la base del problema de la apropiación cultural no son menos vigentes. Sin embargo, con atención principal, pero no exclusiva, a representaciones artísticas y ficcionales de la discapacidad, me parece que este problema tiene que ser matizado todavía en función de la existencia de dos tipos de apropiación, dependiendo de si la discapacidad se representa como tal, es decir, como objeto, motivo y tema, o se utiliza como símbolo, metáfora o alegoría para expresar significados nuevos.

Para distinguir mejor entre estos dos niveles semánticos que, por supuesto, en realidad a menudo se combinan e interaccionan, recurro a la teoría de la metáfora y a los términos de 'tenor' (contenido) y 'vehicle' (vehículo) como componentes de la metáfora, introducidos por el crítico literario inglés Ivor Armstrong Richards (1893-1979), uno de los fundadores del New Criticism, en su estudio The Philosophy of Rhetoric (1936). ${ }^{8}$ En concordancia con esta terminología, la discapacidad es 'tenor' cuando el significado es ella misma y 'vehículo' cuando su significado es otro. ${ }^{9}$ En el caso de que la discapacidad se considera como 'tenor' se suele discutir, por lo general, hasta qué punto la diversidad funcional se presenta como manera de ser cualquiera o identidad normal o más bien como

6 Cf. Weidner (2017).

7 Cf. Fischer (2018).

8 Véase Armstrong Richards (1971: 96-103).

9 Mientras que la distinción entre motivo y tema es puramente cuantitativa, la distinción entre 'tenor' y 'vehículo' es de índole cualitativa, semántica. 
desviación de la normalidad al resaltar su percepción como exótica, grotesca, ridícula, monstruosa o, eventualmente, genial. En el caso contrario en el que la discapacidad se enfoca como 'vehículo', o sea, símbolo, metáfora o "prosthesis", según David T. Mitchell y Sharon M. Snyder, ${ }^{10}$ de la narración, es, como constata Susanne Hartwig, "el soporte de una denuncia o un recurso estético muy fuerte, por ejemplo, de Alzheimer como metáfora de la pérdida de la memoria de un grupo social, la deformación corporal como reflejo de la deformación de una comunidad, etc." (2018a: 8). ${ }^{11}$ Finalmente, hay que tener en cuenta que la relación entre 'tenor' y 'vehículo' también se puede convertir en problema ético. Esto ocurre cada vez que la relación entre medios y finalidad se desequilibra, por ejemplo, cuando se pone de manifiesto que el 'vehículo' se realiza a costa del 'tenor' sin respetarlo suficientemente como finalidad en sí mismo.

A continuación, me propongo analizar, de manera ejemplar, el doble aspecto de la específica 'apropiación cultural' de la discapacidad centrándome en una película de la directora argentina Albertina Carri, nacida en 1973 en Buenos Aires. Con su documental Los rubios (2003), que marcó época en la historia de la memoria de la última dictadura militar en Argentina, ${ }^{12}$ y los tres largometrajes ficcionales con los que continuó su carrera, Carri se ha establecido como una de las directoras más destacadas del nuevo cine latinoamericano. Sus películas estéticamente inusitadas y temáticamente provocadoras siempre giran casi obsesivamente en torno a fenómenos de desintegración personal y social -violencia, trauma e incomunicación- cuyo núcleo es la desintegración familiar: la 'desaparición’ de los padres de Carri durante la dictadura el 14 de febrero de 1977 cuando tenía cuatro años en Los rubios (2003), el incesto entre jóvenes hermanos de una típica familia de la burguesía argentina en Géminis (2005) y el enredo

10 Para una definición de este concepto véase Mitchell/Snyder (2000: 4-10). Los autores explican su intención como sigue: "we want to demonstrate that the disabled body represents a potent symbolic site of literary investment" (49) comprendiendo la discapacidad como "a narrative device - an artistic prosthesis - that reveals the pervasive dependency of artistic, cultural, and philosophical discourses upon the powerful alterity assigned to people with disabilities" (51).

11 En esta línea, por ejemplo, Ryan Prout analiza cómo en la película mexicana Las buenas hierbas (2010), de María Novaro, la enfermedad de Alzheimer sirve de "metaphorical vehicle" (93) al utilizar "individual loss of memory as a route to remembering cultural forgetting" (83).

12 Cf. Aguilar (2010: 253): "Es que Los rubios fue lo más parecido que hubo en el cine a un acto de descarga, exorcismo y liberación”. 
sexual, y finalmente mortal, de dos familias vecinas en el ámbito rural del campo argentino en La rabia (2008). ${ }^{13}$

En esta última película, Carri elige como enfoque de la narración fílmica a Nati, una niña muda que padece de un autismo no diagnosticado, ignorado por su entorno. A través de su excepcional percepción visual y acústica, Nati sirve de observadora discreta, o, según la formulación de Inela Selimović, de "autistic ethnographer" (2018: 39), que al mismo tiempo se evade de la violencia endémica que la rodea y que testimonia al plasmar sus experiencias traumatizantes en dibujos que se transforman reiteradamente en secuencias animadas. De este modo, el autismo de Nati permite una doble lectura conforme a nuestra distinción entre la discapacidad como 'tenor' y 'vehículo'. Por un lado, desde el punto de vista de los disability studies y del 'cine de discapacidad', La rabia interesa como estudio cuidadosamente documentado sobre el fenómeno del autismo, que se inscribe en una larga serie de la representación cinematográfica de este tipo de diversidad funcional, desde la famosa y muy controvertida producción hollywoodense Rain Man (1988) de Barry Levinson, galardonada con cuatro Premios Óscar en 1989, hasta el sensible melodrama Teströl és lélekröl (Cuerpo y alma, 2017) de la directora húngara Ildikó Enyedi, que ganó el Oso de Oro en el Festival de Cine de Berlín en 2017. ${ }^{14}$ Por otro lado, el autismo de la protagonista infantil invita a una interpretación alegórica dentro del universo fílmico de Albertina Carri y con respecto a otras películas suyas que varían el tema general de la desintegración e incomunicación.

En lo que sigue, se vinculan y comparan estas dos perspectivas a veces conflictivas y a veces armonizantes: el autismo como 'tenor' y 'vehículo', o sea, como motivo de interés propio y como integrante de una poética y estética cinematográfica particular que se opone al cine comercial inscribiéndose claramente en la línea del cine de autor. Como se verá, esto no carece de importancia para el modo en que la película se acerca al tema de la discapacidad.

\section{La discapacidad como 'tenor'}

Después de estas aclaraciones estamos en condiciones de enfocar la discapacidad en La rabia como 'tenor'. El argumento de la película se desarrolla en un poblado perdido de la pampa argentina que lleva el nombre llamativo "La rabia". Se cuenta el enredo trágico de dos familias de campesinos 'disfuncionales': la

13 Para una visión del conjunto de la obra de Carri véase López Riera (2009).

14 Acerca de la representación del autismo en el cine consúltense, entre otros, Osteen (2008a: 29-34; 229-270), Fraser (2013: 34-74), Prout (2016) y Hartwig (2018b). 
familia del ganadero Leopoldo (Víctor Hugo Carrizo) con su esposa Alejandra (Analía Couceyro) y su hija presuntamente autista Nati (Nazarena Duarte) de seis años y el vecino Pichón (Javier Lorenzo) que tiene un hijo, Ladeado (Gonzalo Pérez), de aproximadamente diez años, quien, por su parte, está cojo. Nati y Ladeado son amigos y pasan mucho tiempo juntos paseando por la naturaleza salvaje. Alejandra y Pichón, el vecino, mantienen una relación sexual de índole muy violenta, sadomasoquista, que no pasa inadvertida ni por los niños ni por el marido de Alejandra. Todo termina trágicamente con la muerte de ambos padres de familia: Leopoldo muere a manos de su rival Pichón y a Pichón lo mata su propio hijo, Ladeado.

Aunque Nati, la hija de Alejandra y Leopoldo, lleva rasgos evidentes de un trastorno autista, dentro del mundo ficticio esto no se reconoce como tal. Los demás personajes se refieren a ella simplemente como "la muda". Ni se establece diagnóstico médico alguno ni la niña recibe tratamiento terapéutico. El mundo rural crudo e indiferente, en el que vive, escapa completamente al régimen biopolítico, controlador, regulador y normalizador de la medicina moderna, de la asistencia social y del cuidado pedagógico como lo describió Michel Foucault (1976). Ante las crueldades de la vida campesina cotidiana y de la naturaleza adyacente, ni la mudez ni el comportamiento especial de Nati ni la cojera de Ladeado le llaman la atención a nadie. En este mundo la discapacidad como construcción social todavía no existe y, por consiguiente, nunca se tematiza. A su manera, la sociedad rural es inclusiva sin saberlo. Es obvio que, para los niños, el descuido y el desinterés de su entorno también tienen sus ventajas: una libertad casi total.

Pese a todo, en el personaje de Nati los síntomas del autismo son claramente discernibles. Destacan sobre todo cuatro características: primero, Nati no se comunica verbalmente, tiene problemas para expresar sus sentimientos y establecer relaciones afectivas. Se contenta con el rol de una observadora atenta. Segundo, en situaciones de estrés emocional, se quita espontáneamente la ropa y anda desnuda en público. Tercero, lanza chillidos estridentes de repente. Cuarto, en muchas ocasiones lleva consigo un bloc de dibujo y dibuja lo que observa y lo que le conmueve. ${ }^{15}$

Sin embargo, nunca se aclara durante toda la narración si el autismo de Nati es adquirido o heredado. De todos modos, parece deficiente explicar su mudez simplemente como reacción ocasional a la necesidad de guardar el secreto de la

15 Cf. Josiowicz (2014: 41): "Nati corresponds to what experts in autism view as a person within the autistic spectrum". 
infidelidad de su madre y su impulso de desnudarse como imitación de la desnudez de su madre en el acto sexual con Pichón el cual llega a presenciar varias veces. En una historia de horror que le cuenta su padre a Nati para disuadirle de quitarse la ropa, se insinúa, por el contrario, la existencia de una disposición hereditaria, al evocar la mujer de un tío abuelo a quien también le gustaba desnudarse. Con todo, como recuerda Joachim Michael, "la película no propone que los niños sólo reciban daños de sus padres. Hay muchas escenas en que ambos padres tratan a Nati con cariño" (2016: 136). De hecho, la película a menudo hace hincapié en el contacto háptico y corporal entre Nati y sus padres. La misma intención de matizar se refleja también en la actitud de los padres frente al qué dirán. Mientras que la madre se preocupa “¿Poldo, qué esperas que diga la gente? ¿Si esta no habla y grita como un chancho? No es normal”, el padre, por su parte, relativiza: "Ya va a aprender a hablar" (00:48:30).

Es muy instructivo tomar en consideración lo que dice la propia Albertina Carri sobre el tema del autismo en una entrevista hecha por Iván Pinto Veas para la revista La fuga:

Desde los comienzos estaba la idea de un niño cojo (Ladeado) y una niña muda. Después la niña muda va adquiriendo ciertos rasgos autistas. El hecho de que se saque la ropa tiene que ver con eso. Por las imposibilidades físicas que te trae eso. Por otro lado esa relación que tiene el campo con la enfermedad. Es decir, el niño cojo que quedó cojo. Lo mismo con la niña. Yo hace rato que vengo investigando sobre el autismo. Hay un libro que se llama El curioso incidente de un perro a media noche, donde el protagonista es un niño autista. ${ }^{16}$ Saqué algo de ahí, algo de la expresión. Ese niño no soporta el contacto físico. Reacciona violentamente. Pero se puede contactar de otras maneras. Puede dar abrazos, tocarse las manos con otros, encontrar otro tipo de lenguaje, y esa idea de encontrar otro tipo de lenguaje es lo que me interesaba con la niña. Sobre todo con ningún recurso a su favor, cómo, a pesar de no tener ninguna estimulación por parte de los adultos, a la niña igual su imaginación y su fantasía se disparan. Y su necesidad de comunicarse también se le dispara. Y aunque no hable, comunica. Claramente comunica. Y mucho más que los demás, y los demás que supuestamente comunican se terminan matando... (Pinto Veas 2008a: 3 )

El empeño de Albertina Carri de brindar una imagen auténtica del autismo incluye también la decisión de invitar al espectador a compartir la percepción tanto del mundo exterior como interior de la protagonista infantil. Al insertar

16 Aquí Carri se refiere a la novela de éxito The Curious Incident of the Dog in the NightTime (2003) del escritor británico Mark Haddon, que se dirige a lectores jóvenes y adultos a la vez y relata desde la primera persona la historia de un chico de 15 años, Christopher John Francis Boone, que padece el síndrome de Asperger. 
a menudo grandes planos e incluso planos en detalle del rostro y la mirada de Nati, Carri vincula sistemáticamente las imágenes fílmicas con el punto de vista de la niña (Fig. 1).

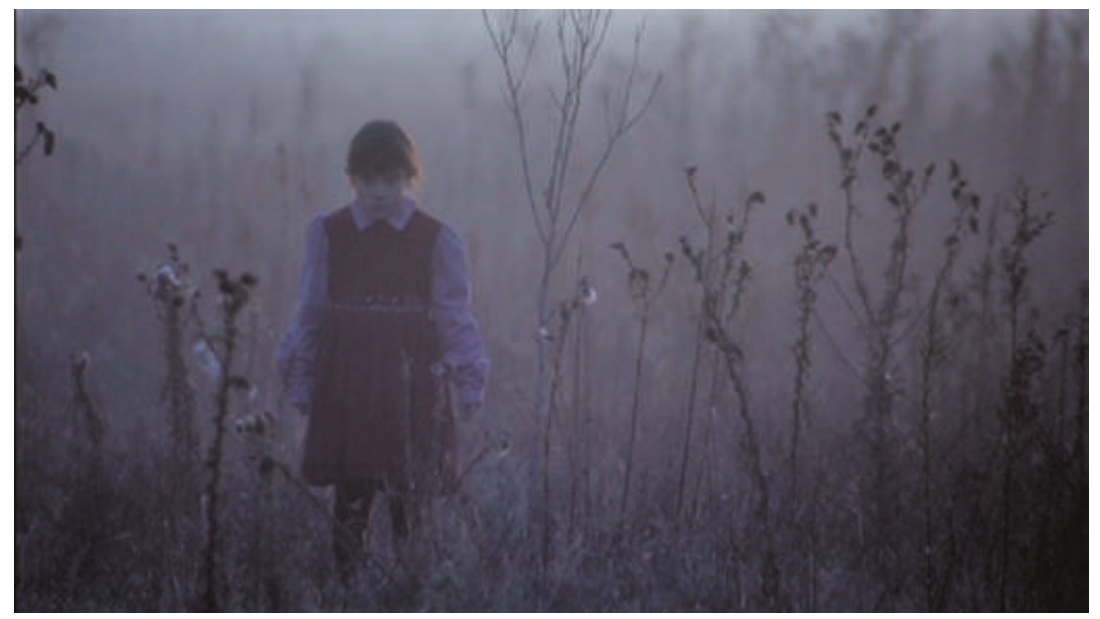

Fig. 1: Nati en la naturaleza salvaje (00:00:52)

El mismo proceso de subjetivación de la percepción caracteriza la banda sonora que es muy compleja y elaborada. Los ruidos del campo y de la naturaleza -los gritos y chillidos de los pájaros, el ladrar de los perros, el balar de las ovejas, el mugido de las vacas y el gruñido de la comadreja adoptada por Ladeadose acentúan y hasta exageran de una manera hiperrealista, como si la ausencia del lenguaje se compensara por una intensificación de la percepción sensorial. ${ }^{17}$ La primera secuencia de la película ya es paradigmática de este tipo de puesta en escena destinada a evocar una atmósfera que se supone que corresponde a la manera 'mágica' como Nati percibe el mundo. Se ve a Nati vestida de rojo vagando sola por el campo en las neblinas del día incipiente. Se agacha para orinar y continúa su camino en harmonía preverbal con el paisaje arcaico de la pampa. Pasan seis minutos y medio hasta que se pronuncia la primera palabra (Fig. 2).

17 En términos de narratología cinematográfica se hablaría, según Gaudreault/Jost 1990: 129-136, de ocularización y auricularización interna (primaria y secundaria). 


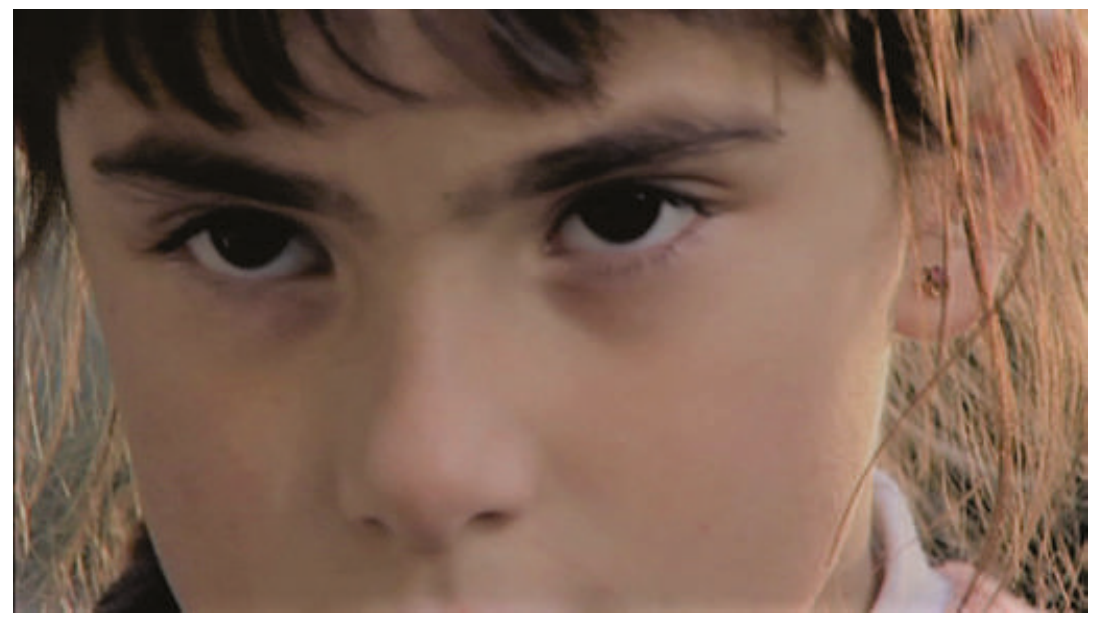

Fig. 2: La mirada de Nati (00:33:30)

En cambio, el acceso al mundo interior de Nati se realiza a través de cinco secuencias de dibujos animados de casi seis minutos en total que se intercalan en el desarrollo de la acción cada vez que Nati se siente particularmente angustiada por algo. ${ }^{18}$ Este recurso, en el que radica en buena parte la originalidad de la película de Carri, no es tan singular como se podría pensar. Ya Carri había utilizado muñecos Playmobil para reconstruir algunas escenas de su infancia en el campo y del secuestro de sus padres en algunas secuencias de Los rubios. De igual modo, se integran secuencias de dibujos animados en otra película argentina reciente, Infancia clandestina (2012), de Benjamín Ávila. En todos los casos el recurso a la animación se relaciona con la representación de la violencia y el mundo y la perspectiva infantil.

En realidad, hay dos tipos de dibujos en La rabia: primero, los relativamente sencillos que dibuja Nati delante de la cámara y que muestran con un realismo crudo las escenas de sexo que ha presenciado, entre ellos la imagen de un hombre con pene erigido, parecido a Pichón (Fig. 3); el segundo tipo de dibujos lo constituyen las secuencias animadas, una combinación de aguatinta ante un fondo de acuarela, que son de una calidad estética extraordinaria y visualizan, como precisa Carri, "fantasías de la niña" (Pinto Veas 2008a: 3) en vez de ser comentarios del narrador (Fig. 4). En este sentido, la calidad altamente artística de los dibujos animados en La rabia subraya la idiosincrasia del mundo que la autista Nati se

18 Para tener una idea de cómo se reparten estas secuencias a lo largo de la película se remite al "desglose secuencial de La rabia" en Dufays (2016: 284-287). 
ha creado para escapar a una realidad que de otro modo sería insoportable para ella. Al mismo tiempo, la actividad de Nati hace pensar en el papel desempeñado por los dibujos en el tratamiento de traumas psíquicos. ${ }^{19}$

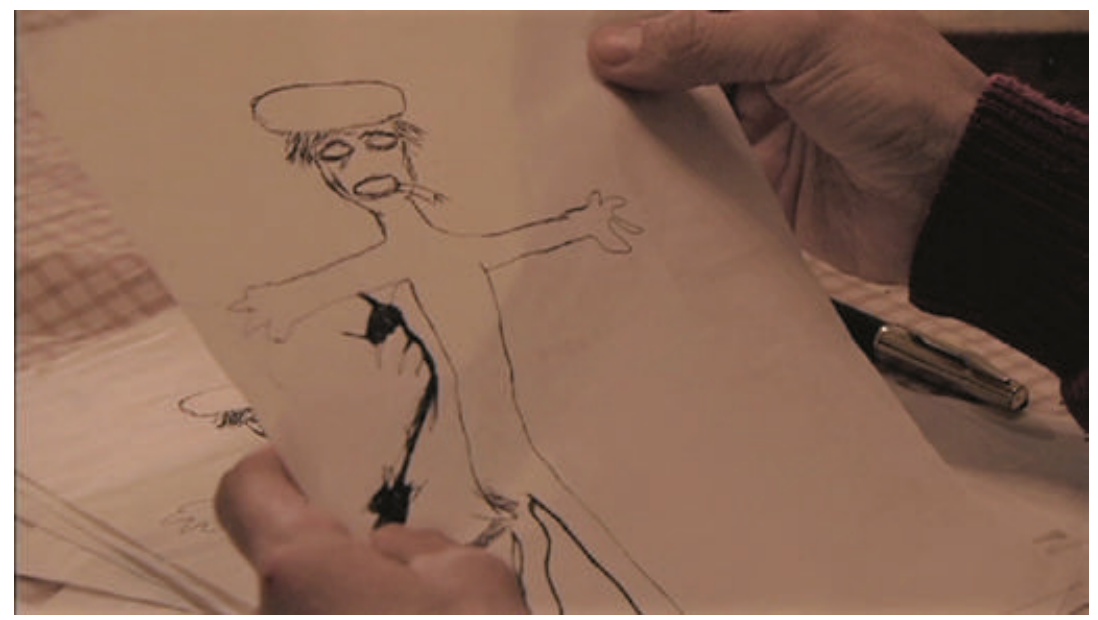

Fig. 3: Los dibujos de Nati (01:11:34)

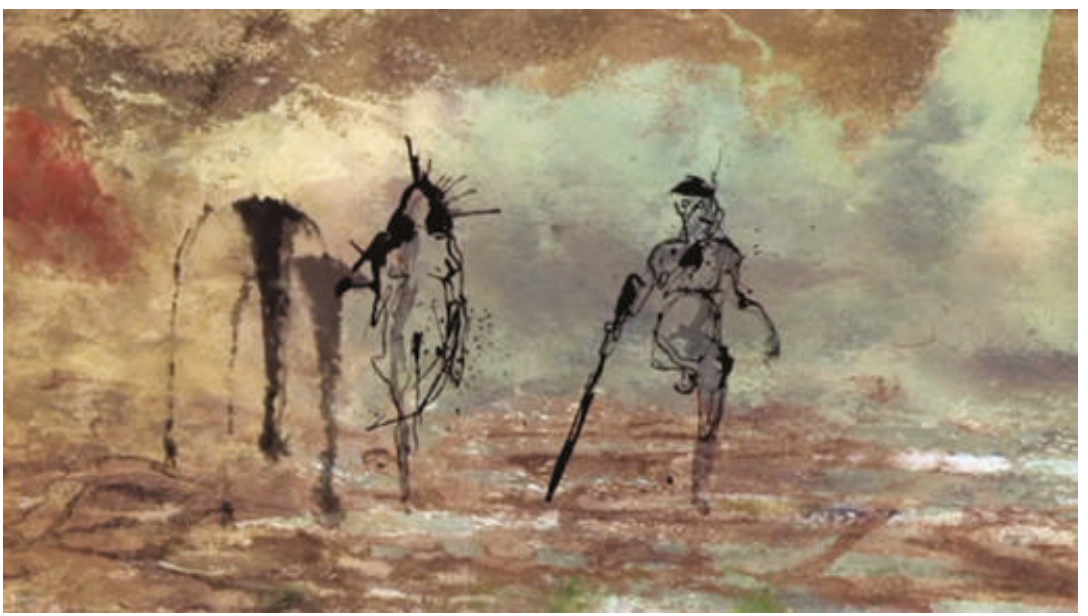

Fig. 4: Las secuencias animadas (00:16:03)

19 Para un estudio más detenido de las secuencias animadas véanse Kairuz (2009), López Riera (2009: 87-90), Andermann (2012: 83), Tompkins (2012: 197), Josiowicz 
$\mathrm{Al}$ insistir claramente en la diferencia entre los dos tipos de imágenes -dibujos reales de Nati y dibujos 'auctoriales' que representan sus procesos mentales- Carri logra valorar la riqueza del mundo interior de su protagonista discapacitada, subrayando su individualidad y estatus de sujeto, sin caer, no obstante, en el estereotipo de dotarle de un talento artístico excepcional y de presentarle como autista de alto funcionamiento. ${ }^{20}$

\section{La discapacidad como 'vehículo'}

Llegado a este punto de la argumentación es hora de cambiar de perspectiva y considerar la discapacidad de Nati como vehículo para la narración de una historia ficticia que obedece tanto a imperativos dramatúrgicos particulares como a la visión del mundo altamente personal de una representante por excelencia del cine de autor que "defiende ferozmente una concepción artesanal y libre del cine" (Molloy 2017: 104) y cuyos filmes han sido calificados "de obras incómodas, con poca concesión y de difícil acomodamiento" (Pinto Veas 2008b: 2).

La marginalidad del cine de Albertina Carri frente al cine convencional y comercial coetáneo establece desde el inicio un vínculo de similitud y parentesco con la marginalidad social y existencial de su protagonista. Efectivamente, en La rabia la figura de la autista Nati no solamente funciona como objeto de identificación para el espectador, lo cual no tiene nada de inusual en el cine de discapacidad, sino también para la misma directora del filme que no se centra por casualidad en la rica imaginación de la niña y su capacidad de creación y expresión alternativa. Cabe recordar que en la entrevista antes mencionada, Carri advirtió explícitamente que lo que más le interesaba en el personaje de la autista era la "idea de encontrar otro tipo de lenguaje" (Pinto Veas 2008b: 3). ${ }^{21}$ A esta 'afinidad electiva' se suma el parecido aun más elemental entre el autismo y el cine como medio de comunicación que destaca por su carácter principalmente

(2014: 45-46), Alonso (2015: 3-4), Tompkins (2015: 144), Dufays (2016: 225-226; 227-232; 256-264), Selimović (2018: 38; 47-48) y Tschilschke (2018b).

20 Cf. Selimović (2018: 39): "The young child is not exceptional at any skill."

21 Este aspecto se profundiza particularmente en Josiowicz (2014). Según ella, Nati se convierte en un "agent of expression" (43): "She is the aesthetic creator of a vision representing that which cannot be represented" (41); "These images enact a 'coming to voice' of the violent drives of the little girl" (46). 
visual, independiente de la palabra y su potencial de crear la ilusión de un contacto en cierto modo háptico con el mundo. ${ }^{22}$

Además de cumplir una función metacinematográfica, de mise en abyme del medio en general y del concepto del cine específico de Albertina Carri en particular, a nivel del discurso cinematográfico, de la puesta en imagen y sonido del mundo fílmico, el autismo sirve también para motivar una mirada de testigo, observadora, distanciada, impasible y, al menos en parte, moralmente indiferente sobre un mundo rural en el que la relación del hombre con la naturaleza y de los hombres entre sí está determinada por una violencia casi endémica. ${ }^{23}$ En este contexto, el autismo de Nati solamente refuerza y radicaliza los rasgos típicos de la perspectiva infantil que ya de por sí se distingue por un cierto mutismo en consonancia con el origen latín de la palabra 'infantil', 'el que no habla', como recuerda Sophie Dufays (2016: 224).$^{24}$ La impasibilidad de este estilo, que podría calificarse como 'neorrealista' o incluso 'tremendismo argentino', se manifiesta ante todo en la representación casi documental de largas escenas violentas, como, por ejemplo, el ahogamiento despiadado de una comadreja y su cría por Ladeado, la matanza profesional de un cerdo por los campesinos o el sexo 'animal', de una explicitud pornográfica, entre Alejandra y Pichón. ${ }^{25}$

22 El carácter particularmente háptico de la estética fílmica de Carri se analiza en Molloy (2017).

23 La misma Albertina Carri habla de "la naturalización absoluta de la violencia" (Kairuz 2009) que caracteriza la vida en el campo.

24 Dufays destaca dos funciones en la representación de la mudez de Nati que son similares a nuestra distinción entre el autismo como 'tenor' y 'vehículo': "Desde el punto de vista de la psicología del personaje, la mudez de la niña que observa y, a veces, espía esas escenas responde a una función expresiva: expresa el choque causado por la visión de la violencia y la interiorización de la consigna de sumisión que le inculca su madre. Desde un ángulo más cinematográfico, permite subrayar la función de testigo visual del niño y el misterio de su percepción imaginaria" (2016: 224). Según la interpretación de Josiowicz la figura de Nati opera "as a metaphoric agent of aesthetic discourse" (2014: 37).

25 Es interesante notar hasta qué punto difieren las interpretaciones respecto a la apasionada relación sadomasoquista entre la madre de Nati y su vecino Pichón. Mientras que Alejandra Josiowicz la percibe como "animalistic, sadistic gender violence" (2014: 35) denunciándola como "abuse" (41), Albertina Carri la ve como una variante individual de la sexualidad: "un sexo puramente carnal pero no por eso carente de amor" (López Riera 2009: 191). De hecho, el sexo entre Alejandra y Pichón es voluntario, lo que, por supuesto, no excluye que sea interpretado como expresión de un orden patriarcal opresor, al que Alejandra, como esposa, madre y ama de casa, está obviamente sometida. 
A nivel diegético, por último, el autismo de Nati asume evidentemente una trascendencia alegórica en la que se reflejan no solamente la incomunicación y desintegración que reinan entre los miembros de la comunidad en la que vive -parejas, familias, vecinos, generaciones, etcétera-, sino también el específico complejo que forman la experiencia de la violencia y los traumas y tabús resultantes. En este sentido, el autismo de Nati forma parte de una red de motivos, influencias y analogías con otras películas de Albertina Carri como el documental Los rubios, que describe las pesquisas sobre el destino de los padres desaparecidos de la directora durante la última dictadura militar en Argentina, y la película de ficción Géminis dedicada al tema del incesto entre los hermanos adolescentes, Meme y Jeremías, en una familia poco intacta de la alta burguesía argentina. No obstante, la interpretación del autismo en La rabia como alegoría no estaría completa sin tomar en cuenta el hecho de que se presenta también como acto de resistencia a un mundo perverso, al revés, en el que el personaje discapacitado, en vez de servir, como de costumbre, para "explicar la anormalidad dentro de la normalidad, por ejemplo, a través de un crimen, una culpa o un destino trágico" (Hartwig 2018a: 8) - aparece como único representante de la normalidad dentro de la anormalidad reinante.

\section{Conclusión}

La propuesta de distinguir entre la representación de la discapacidad como 'tenor' y 'vehículo' permite diferenciar la forma en que los medios se apropian de y transforman el tema de la diversidad funcional según sus propias reglas. Si bien es verdad que el uso del motivo de la discapacidad como 'vehículo', es decir, en sentido figurado, no es un privilegio de los textos de ficción, estos tampoco pueden prescindir de este uso que les es inherente. Como hemos visto, el melodrama rural La rabia de Albertina Carri resulta particularmente apropiado para analizar la distinción entre 'tenor' y 'vehículo', porque no solamente presenta una imagen diferenciada y solidaria del autismo, sino que también dota esta imagen de un sentido figurado a varios niveles - diegético, discursivo y metacinematográfico-. Como este nunca entra en contradicción con el sentido literal de la obra ni se realiza en detrimento de este, tampoco puede parecerle éticamente inapropiado a nadie. 


\section{Filmografía}

Amenábar, Alejandro. 2004. Mar adentro, España/Francia/Italia.

Ávila, Benjamín. 2012. Infancia clandestina, Argentina/Brasil/España.

Carri, Albertina. 2003. Los rubios, Argentina.

Carri, Albertina. 2005. Géminis, Argentina/Francia.

Carri, Albertina. 2008. La rabia, Argentina.

Coogler, Ryan. 2018. Black Panther, Estados Unidos.

Dhont, Lukas. 2018. Girl, Bélgica/Países Bajos.

Enyedi, Ildikó. 2017. Teströl és lélekről (Cuerpo y alma), Hungría.

Lelio, Sebastián. 2017. Una mujer fantástica, Chile/Estados Unidos/Alemania/ España.

Levinson, Barry. 1988. Rain Man, Estados Unidos.

Novaro, María. 2010. Las buenas hierbas, México.

Toro, Guillermo del. 2017. The Shape of Water, Estados Unidos.

\section{Bibliografía}

Aguilar, Gonzalo. 2010. Otros mundos: Un ensayo sobre el nuevo cine argentino, 2. ${ }^{a}$ ed. actualizada, Buenos Aires: Santiago Arcos.

Alonso, Mercedes. 2015. "Niños y animales", en: La Fuga 17: 1-6, http://2016. lafuga.cl/ninos-y-animales/740 [15.03.2019].

Andermann, Jens. 2012. New Argentine Cinema, London/New York: Tauris.

Checa, Julio/Hartwig, Susanne (eds.). 2018. ¿Discapacidad? Literatura, teatro y cine hispánicos vistos desde los 'disability studies', Berlin et al.: Peter Lang.

Dufays, Sophie. 2016. Infancia y melancolía en el cine argentino. De "La ciénaga" a "La rabia", Buenos Aires: Editorial Biblos.

Fischer, Jonathan. 2018. "Nach Wakanda. Der Blockbuster Black Panther und der Streit um die kulturelle Aneignung: Wem gehört eigentlich die schwarze Kultur?", en: Süddeutsche Zeitung 79 (6 de abril): 10.

Foucault, Michel. 1976. Histoire de la sexualité I. La volonté de savoir, Paris: Gallimard.

Fraser, Benjamin. 2013. Disability Studies and Spanish Culture. Films, Novels, the Comic and the Public Exhibition, Liverpool: Liverpool University Press.

Fraser, Benjamin. 2018. Cognitive Disability Aesthetics. Visual Culture, Disability Representations, and the (In)Visibility of Cognitive Difference, Toronto/Buffalo/ London: University of Toronto Press. 
Gaudreault, André/François, Jost. 1990. Cinéma et récit II. Le récit cinématographique, Paris: Nathan.

Haddon, Mark. 2003. The Curious Incident of the Dog in the Night-Time, London: Jonathan Cape.

Hartwig, Susanne. 2018a. "Introducción: representar la diversidad funcional", en: Checa/Hartwig 2018: 7-21.

Hartwig, Susanne. 2018b. "Positions of partiality: acercamientos a la diversidad funcional cognitiva", en: Checa/Hartwig 2018: 187-210.

Josiowicz, Alejandra. 2014. "Scribbles from a Little Girl. Violence and The Politics of Girlhood in Albertina Carri's Géminis and La rabia", en: Carolina Rocha/Georgia Seminet (eds.), Screening Minors in Latin American Cinema, Lanham et al.: Lexington: 35-50.

Kairuz, Mariano. 2009. "En el campo las espinas", en: Página 12 (4 de mayo). http://www.pagina12.com.ar/diario/suplementos/radar/9-4593-2008-05-04. html [15.03.2019].

López Riera, Elena. 2009. Albertina Carri. El cine y la furia, Valencia: Ediciones de la Filmoteca.

Michael, Joachim. 2016. "Ruinas del tiempo: el campo en el cine argentino contemporáneo", en: Bernhard Chappuzeau/Christian von Tschilschke (eds.), Cine argentino contemporáneo: visiones y discursos, Madrid/Frankfurt a. M.: Iberoamericana/Vervuert: 123-139.

Mitchell, David T./Snyder, Sharon L. 2000. Narrative Prosthesis. Disability and the Dependencies of Discourse, Ann Arbor: The University of Michigan Press.

Molloy, Missy. 2017. "Queer-Haptic Aesthetics in the Films of Lucrecia Martel and Albertina Carri", en: Studies in Spanish \& Latin American Cinemas 14 (1): 95-111.

Mullaly, Laurence. 2012. "Albertina Carri: Cinéaste de l'inconfort/Albertina Carri: Cineasta de la incomodidad”, en: Cinémas d’Amérique Latine 20: 162171.

Osteen, Mark (ed.). 2008a. Autism and Representation, New York/London: Routledge.

Osteen, Mark. 2008b. "Autism and Representation. A Comprehensive Introduction”, en: Osteen 2008 (ed.): 1-47.

Pinto Veas, Iván. 2008a. "Entrevista a Albertina Carri. A propósito de $L a$ rabia", en: La Fuga 8: 1-4, http://www.lafuga.cl/entevista-a-albertina-carri/5 [15.03.2019].

Pinto Veas, Iván. 2008b. “La rabia”, en: La Fuga 8: 1-3, http://2016.lafuga.cl/ la-rabia/102 [15.03.2019]. 
Prout, Ryan. 2016. "Otras competencias. Ethnobotany, the Badianus codex, and Metaphors of Mexican Memory Loss and Disability in Las buenas hierbas (2010)", en: Susan Antebi/Beth E. Jörgensen (eds.), Libre Acceso. Latin American Literature and film through Disability Studies, New York: State University of New York Press: 83-101.

Richards, Ivor Armstrong. [1936] 1971. The Philosophy of Rhetoric, New York: Oxford University Press.

Scafidi, Susan. 2005. Who Owns Culture? Appropriation and Authenticity in American Law, New Brunswick: Rutgers University Press.

Selimović, Inela. 2018. Affective Moments in the Films of Martel, Carri, and Puenzo, London: Palgrave Macmillan.

Stadelmaier, Philipp. 2018. "Komplett normal. Der preisgekrönte Film Girl von Lukas Dhont zeigt, wie ein Transmädchen seine Identität findet", en: Süddeutsche Zeitung 244 (23 de octubre): 14.

Tompkins, Cynthia Margarita. 2012. "Cuestiones metodológicas resultantes del montaje ejemplificadas mediante la representación de procesos psíquicos en La rabia (2008) de Albertina Carri", en: Estudios Sobre las Culturas Contemporáneas. Revista de Investigación y Análisis 18 (36): 189-210.

Tompkins, Cynthia Margarita. 2015. "Wild Naked Ladies: Shifting Paradigms. Gendered Approaches to María Victoria Menis's Cámara oscura (Camera Obscura) (2008) and Albertina Carri's La rabia (Anger) (2008)", en: Leila Gómez et al. (eds.), Teaching Gender through Latin American, Latino and Iberian Texts and Culture, Rotterdam: Sense: 141-156.

Tschilschke, Christian von. 2018a. "La discapacidad en la mira de la docuficción: Mar adentro (2004) de Alejandro Amenábar”, en: Checa/Hartwig 2018: 153-166.

Tschilschke, Christian. 2018b. "Stop (e)motion. El recurso a la animación en el cine argentino contemporáneo", en: Christoph Strosetzki (ed.), Aspectos actuales del hispanismo mundial, t. 2, Berlin/Boston: De Gruyter: 347-359.

Weidner, Carolin. 2017. "Transgender-Drama Eine fantastische Frau", en: Spiegel Online (6 de septiembre), http://www.spiegel.de/kultur/kino/ transgender-drama-eine-fantastische-frau-was-zum-gucken-a-1166184.html [15.03.2019].

Weidner, Carolin. 2018. "Die Kamera sucht die Beule. Lukas Dhonts Film Girl", en: taz (17 de octubre), http://www.taz.de/!5540889/ [15.03.2019]. 


\title{
Beatriz Miranda Galarza \\ 17, Instituto de Estudios Críticos
}

\section{De la norma al nombre: el arte y la invitación a reinventar el activismo en la "discapacidad"}

\begin{abstract}
From the reflection on the methodological process followed in the organization and development of the Colloquium Art and "disability": from the norm to the name, this chapter presents the proposal of creation of a collective of artists with disabilities in Mexico. The promise that comes with it is linked to two elements: the resignification of the position of the artist with disabilities inside and outside the Mexican artistic and cultural circuit and the reinvention of the associative movement of people with disabilities in the country. It also includes a reflection on the role of academic institutions such as 17, Institute of Critical Studies, artists and researchers who are recognized as "allies" and whose presence as allies implies the revision of traditional forms of work that contrast with the principle of "nothing about us without us".
\end{abstract}

Keywords: art, disability, Mexico, social movement, 17, Institute of Critical Studies

\section{Introducción}

¿La Venus de Milo todavía sería considerada uno de los mejores ejemplos de belleza tanto estética como humana si todavía tuviera ambos brazos? Tal vez sea una exageración considerar a la Venus como "discapacitada", pero René Magritte, por ejemplo, no lo consideró así. Pintó su versión de Venus, Les Menottes de cuivre, en tonos carne, pero salpicado de pigmento rojo sangre, dando la impresión de una amputación reciente y dolorosa

(Tobin Siebers, Disability Aesthetics)

En 2005, una escultura de 12 pies de alto que representa a Alison Lapper ${ }^{1}$ desnuda y embarazada, fue colocada en Trafalgar Square en Londres. La escultura, realizada por el artista también británico Marc Quinn y colocada junto a la columna en honor al almirante Nelson, fue observada por millones de personas y trajo consigo críticas de las más variadas. Entre las críticas se citaba que la "escultura no encajaba con las estatuas tradicionales que ya adornaban la plaza"; o, "necesitamos algo más profundo e histórico para Trafalgar Square". Janice

1 Artista británica con "discapacidad” que nació sin brazos y sin piernas. 
Turner, columnista de The Times, opinó que la plaza "debería celebrar a quienes han construido nuestra nación. Alison Lapper nunca ha hecho nada, simplemente ha existido, [y] ha tratado de hacer lo mejor con su desafortunado cuerpo" (Turner 2005). El planteamiento de Siebers y las críticas realizadas al trabajo de Quinn, representan la contradicción y la complejidad embebidas en el campo del arte y la discapacidad. Complejidad que 17, Instituto de Estudios Críticos ${ }^{2}$ en México ha querido convertir en espacio de reflexión y de construcción. Para ello, en junio del 2018, 17, llevó a cabo su XXV coloquio titulado Arte y "discapacidad": de la norma al nombre 3 . La propuesta del evento surgió como respuesta a interrogantes nacidas del trabajo crítico desde 17, a los discursos que abordan la discapacidad y que se vio plasmado en el primer coloquio sobre estudios críticos de la "discapacidad" en el 2013; y, a la insatisfacción con las propuestas presentadas por diversas organizaciones en el campo del arte y la discapacidad. Cabe decir, que, a partir de estos antecedentes, se amplió un diálogo ya antes establecido con diferentes artistas en el ámbito de la discapacidad y fuera de ella. ¿Por qué consideramos a algunos creadores como "artistas con 'discapacidad" y a otros sin más como artistas (aunque también vivan con alguna "discapacidad")? ¿bajo qué condiciones el peso simbólico comúnmente asociado con la "discapacidad" cede a la fuerza del nombre del artista? ¿qué es lo que la creación "desde la 'discapacidad' " interpela?, ¿cuáles son los efectos de dicha interpelación entre el público?, ¿qué ilumina la figura del curador "con 'discapacidad'”? (figura aún tan inusual en el mundo de habla hispana), ¿cómo alumbra particularmente el "artista con 'discapacidad" el enigma general de la creación?, ¿y cómo renuevan todas estas cuestiones el campo contemporáneo del arte? En México y América Latina, la práctica del arte-terapia ha sido objeto de apoyo y gestión desde la década de 1960. La institucionalización de esta, en muchas ocasiones, ha implicado un guion normalizador que ha perpetuado al "artista con 'discapacidad' " en un canon capacitista. El efecto: invisibilizarlo y hasta infantilizarlo. Al respecto, Solvang sostiene que aquello que conocemos como arte vinculado a la creación artística como tal, desde la discapacidad, difiere de otras expresiones como el arte-terapia que ha sido implementado desde las ciencias médicas y psicológicas; del outsider art, que constituye todo aquello producido por fuera de la institución

2 17, interviene en problemas desatendidos por otras instancias: promueve la investigación, la enseñanza y la difusión de los estudios críticos. Asimismo, promueve intervenciones culturales, brinda servicios de consultoría https://17edu.org/. Hace converger al conjunto de sus facetas en las publicaciones que edita: www.diecisiete.org.

3 Para más información y documentación: https://www.youtube.com/channel/UCJYaItD1Seg5tKse1AGjn8g/videos. 
artística y que es valorado por coleccionistas de arte; y de lo que llamaríamos estética producida desde la discapacidad que intenta recuperar históricamente el valor de una estética presente en el arte producido desde la discapacidad ${ }^{4}$. Generalmente, la autora continúa, artistas afiliados a la producción artística desde la discapacidad toman distancia de las dos primeras expresiones y dan la bienvenida a la tercera. No sorprende, entonces, la diversidad de relaciones que tales creadores establecen con "su" "discapacidad": al cuestionarla, oponerse a ella, o afirmarla. Permanece, así, irresuelto el reconocimiento de estos artistas, su producción, la naturaleza de su lucha; así como, resta valorar su singularidad.

A partir de estas reflexiones, a lo largo de tres jornadas, enriquecidas por exposiciones, performances y talleres adyacentes, se dio paso al conocimiento y debate de las propuestas de algunos de los más destacados artistas (con "discapacidad") activos en México, así como en la esfera internacional. Con la particularidad que esta puesta en escena se la hizo en diálogo con artistas y curadores renombrados del ámbito cultural mexicano. Este experimento, trajo a la mesa del debate planteamientos que terminaron por provocar la propuesta de formación del primer colectivo de artistas con diversas discapacidades en México, que se autodenominan Discreantes.

En este artículo, la autora, busca informar sobre la relevancia de la formación de dicho colectivo, mediante el recuento metodológico del coloquio y las posibles pistas dejadas en las discusiones para dar respuesta a las preguntas en las que se enmarcó el evento. Así mismo, se dejará abierta la pregunta por el posible impacto que la formación y el fortalecimiento de dicho colectivo, pueda tener en la revitalización de un movimiento asociativo de personas con discapacidad que se encuentra fracturado en el país; y el rol que tendrán en el proceso quienes denominaremos "aliados", en este caso 17, Instituto.

\section{Arte y discapacidad: nombre e identificación}

Resulta imposible plantear un espacio de diálogo sobre el arte y la discapacidad sin convocar la discusión sobre identificación y la posición del artista frente a ella. En agosto de 2016, 17, invitó a los artistas visuales Alex de Jong de Holanda ${ }^{5}$ y Laetitia Boulud de Canadá/Israel a que colaboraran con lo que considerábamos

4 En este campo, Tobin Siebers en su obra Disability Aesthetics rescata la discusión sobre el problema de la estética, el arte y el cuerpo y, sostiene que la discapacidad como categoría se encuentra en proceso de maduración hacia un valor estético en sí misma.

5 Artista visual, para conocer más https://fstopbeyond.wordpress.com/2009/12/17/ fsb099-alex-de-jong/. 
el apuntalamiento teórico y estratégico del coloquio. Alex y Laetitia, artistas visuales ciegos, cuentan con un recorrido artístico que ha combinado el cuestionamiento a la clasificación de arte y discapacidad con la producción artística y las instalaciones que interpelan constantemente la idea de "normalidad" sostenida tanto por personas con discapacidad o sin ella. Una serie de conversaciones e intercambios tuvieron lugar vía Skype y correo electrónico, respecto a una que era vista como dicotomía absurda: arte y discapacidad. Absurda en la medida que identificábamos el arte como lo primario y la discapacidad como aquello que no necesariamente debería jugar un papel en la identificación del artista, a menos que él o ella así lo decidiera. La pregunta inicial que nos surgía, relacionado con este punto central, era la de cómo poner sobre la mesa de discusión el trabajo del artista y su recepción sin que obligatoriamente la audiencia recurriera a la pregunta, en ocasiones torpe y en otras atinada, de su discapacidad y el rol de su cuerpo biológicamente entendido. ¿Cómo transformar la práctica de la identificación de lo artístico con aquello estéticamente normalizado en una práctica de cuestionamiento y de reflexión sobre lo subversivo que constituye el artista con "discapacidad" y su producción? Siendo Alex y Laetitia artistas con discapacidad visual, su posición sobre el arte visual y la identificación con la llamada fotografía de ciegos, por ejemplo, es radical. Alex sostenía que:

En el caso de la fotografía ciega y su praxis, lo que se interroga de manera radical y permanente es la supuesta evidencia de lo visible y la relación natural establecida con ello por los videntes. Nadie va a reificar un tipo de fotografía oculta. No existe la "fotografía ciega". ¿Hay "fotografía negra” o "fotografía femenina”? Es especialmente esto lo que me gustaría interrogar. En cuanto a los calificativos "femeninos", "negros" y demás, aunque encuentro ciertas elaboraciones sobre "écriture fémenin" bastante sugestivas, estas significan algo muy distinto que debería ser considerado al momento de hablar de arte visual de ciegos. De ninguna manera asombra que la "fotografía de ciegos" pueda desempeñar un papel en una especie de política identitaria. De hecho, rechazo la política identitaria visceral. Supongo que estarán de acuerdo en que la misma noción de "fotografía", por ejemplo, es problemática. - cómo es la noción de "universalidad"... Entonces, lo que podría ser de interés en este contexto particular está en otra parte, por supuesto (Correspondencia con Alex y Laetitia, septiembre 2016)

La trayectoria del Instituto en el estudio del campo de la llamada fotografía de ciegos, que se funda en la práctica y reflexión iniciada por Evgen Bavcăr ${ }^{6}$ para

6 Benjamín Mayer Foulkes, fundador y director de 17, Instituto de Estudios Críticos, fue pionero en introducir la fotografía tomada por personas ciegas como un campo de crítica y cuestionamiento al oculocentrismo. Su trabajo y reflexión a partir del encuentro con Evgen Bavcăr ha dado paso a la implementación de diversidad de prácticas 
quien "la cuestión no es cómo un ciego toma fotos, sino cuál es su deseo de imágenes,"7 contrastaba con la posición anteriormente señalada por de Jong. Así, para Mayer Foulkes,

El peculiar malestar que produce el ciego entre los videntes no se debe a la diferencia que guardaría éste con respecto a aquellos, sino a su inquietante identidad: el ciego devela la ceguera de quienes prefieren permanecer ciegos a ella. (Mayer Foulkes 2014: 34)

El dar paso a las diferencias de planteamientos que surgían, incluso entre los mismos artistas, al contrario de señalar una debilidad en el proceso, daba la oportunidad para entender que la reflexión, que se iría tejiendo en la planeación y el desarrollo del coloquio, más que aseveraciones y afirmaciones permitiría plantear preguntas vitales para el armado, poscoloquio, de algo que no conocíamos en qué consistiría. Así, aunque la dicotomía discapacidad-arte fue desde un inicio rechazada, si queríamos traer a escenario al artista y su producción, quedaba claro que el no enunciarla, significaba, de alguna manera cerrar la puerta a que el artista presente su propio posicionamiento, siempre y cuando este sea elaborado desde su misma creación y producción. Es decir, queríamos trabajar con un grupo amplio de artistas donde la regla no era "ser artista con discapacidad" sino la pregunta por el quehacer del artista/de la artista, el cómo lo concibe, como lo plasma y como lo circula. En ello, estaría implícita la reflexión sobre la existencia, o no, de un conglomerado unido por una identidad, artistas con discapacidad; y, quizá incluso, estaría implícita una lucha de posiciones, como lo sugiere Bauman al decir que al hablar de identidad, "cuando se escuche esa palabra, con seguridad hay una batalla ocurriendo" (Bauman 2004: 77). Esta discusión puede ejemplificarse en las posiciones definidas por las artistas plásticas Carmina Hernández ${ }^{8}$ y Ana García ${ }^{9}$ y el artista visual Pedro Miranda ${ }^{10}$. Hernández quien tiene parálisis cerebral, ha construido una carrera dentro del circuito artístico mexicano desvinculándose de la identificación de artista con discapacidad; pese a ello, a la par de su producción ofrece talleres y seminarios a personas, especialmente niñez, con discapacidad. Ana García, una artista

y gestiones desde la figura del fotógrafo ciego, en México. Para publicaciones ver https://17edu.org/editorial/.

7 Mayer Foulkes, B. (2014) El fotógrafo siega. En Mayer Foulkes, B. (compilador) El fotógrafo ciego. Evgen Bavčar en México. Colección Diecisiete (6), 17, Conaculta.

8 Artista plástica, para ver su obra http://carminahernandez.weebly.com/.

9 Artista plástica y visual, para ver su obra https://pics-ci.com.mx/dialogos/Ana-Garcia. html.

10 Artista plástico, visual y multidisciplinario, para ver su obra https://www.animalpolitico.com/2013/01/pedro-miranda-un-fotografo-invidente/. 
joven con discapacidad física severa, reivindica su identidad como artista con discapacidad a través de su discurso y de su obra y asegura que la única vía para provocar cambios en la escena artística mexicana será asumiendo el arte como herramienta política. Pedro Miranda, quien tiene una discapacidad visual, sostiene que su creación no es, de ninguna manera, definida o afectada por su ceguera y que, al contrario, su ceguera, está definida por su creación artística. Solvang (186), luego de entrevistar a artistas vinculados con la discapacidad en Estados Unidos e Inglaterra, concluye que una identidad política asumida desde la discapacidad en el campo del arte, se la puede reconocer en tres niveles: uno en el que dicha identidad está relacionada con el fortalecimiento de una cultura de la discapacidad; una segunda, que apoyada en el modelo social de la discapacidad, sostiene que afirmar una identidad política de la discapacidad es importante pero no suficiente y hay que extenderla; $y$, una tercera, que rechaza una identidad política desde la discapacidad y que ha sido defendida sobre todo por Tom Shakespeare (2006). Las discusiones mantenidas durante el coloquio al respecto hicieron evidente el que hay un camino pendiente de transitar de la norma al nombre. Es decir, de donde la sociedad ubica al artista con discapacidad al reconocimiento de la singularidad del mismo, a lo que Mayer Foulkes ${ }^{11}$ denomina el reconocimiento del nombre propio.

\section{Arte: una convocatoria a reinventar el movimiento asociativo de la discapacidad}

En un intento por materializar un criticismo a una definición de identidad como algo fijo e invariable, Davis (2002) introduce el término dismodernism que refiere a la ruptura con dicha idea y que por el contrario propone que en esta época contemporánea no queda más que hablar de identidades móviles, variables, maleables, cambiantes o incluso que se declaran temporales. Según Davis, la discapacidad es un ejemplo vivo de este, llamemos, "dismodernismo" y su expresión más clara se la viviría en las nuevas formas de asociacionismo que encuentran las personas con discapacidad. Lo líquido de dicha identidad dentro de un movimiento asociativo crearía incluso confrontaciones y desuniones lógicas al interior, pero que, a decir de Davis, generan un diálogo más profundo y más cuestionados de lo que se entiende como normalidad.

11 Una de las discusiones más ricas que tuvo lugar en el coloquio fue respecto al nombre propio del creador y artista y la posibilidad inmediata de que ello provoque cambios en el lugar que ocupa el artista con discapacidad en la sociedad y en el circuito artístico. 
En este punto, es necesario señalar que partíamos de entender la "discapacidad" como una compleja combinación de factores sociales, fisiológicos, culturales, económicos, políticos, lingüísticos, religiosos, subjetivos, regida (dicha combinación) por una fuerza normalizadora y capacitista, que bloquea la posibilidad de entenderla en su potencia en lugar de asumirla desde falencias, faltas o ausencias. Es decir, y valiéndonos del término de Davis, la "discapacidad" entrecomillaría la normalidad en la medida que entendamos su potencia para desequilibrar y romper cánones establecidos respecto al cuerpo y al comportamiento humano; en la medida que cuestionemos a la discapacidad como sinónimo de limitación y anormalidad. La práctica de 17, de escribir "discapacidad” entre comillas, enfoca esta discusión, a la vez, que deja, implícitamente, entendida que la complejidad se aplica no solo a su definición, pero también a su denominación ${ }^{12}$. El concepto traído por Davis quizá nos ayuda a explicar la discusión generada, en una segunda etapa del coloquio, entre los artistas y curadores con y sin discapacidad que contribuyeron al mismo y cuyo resultado fue la propuesta de formación de un colectivo de artistas.

Siguiendo los objetivos que guiaron el coloquio, la comunidad que participó dio cuenta del uso de un espacio donde se dio paso a:

- Establecer un diálogo polifónico sobre la producción artística, donde palabras como inclusión o accesibilidad estén presentes implícitamente, siempre y cuando se conciban dentro del circuito de producción y circulación de la producción artística, no como objetivo final ni como herramienta.

- Cuestionar la práctica de "promover el arte de las personas con discapacidad" y estimular aquella que promueva al artista y su producción/creación.

- Poner sobre la mesa de debate la libertad que el artista debería encontrar para relacionarse con el discurso del cuerpo, si así lo desea.

Ello, permitió que artistas y curadores establecidos en el medio artístico y cultural de México tuvieran un foro para cuestionar lo que consideraban como la ausencia de una unión o un colectivo de artistas que desde la discapacidad definieran su posicionamiento y promovieran una crítica al estado actual de la gestión artística y cultural. De importancia fue la mesa de discusión sobre "curaduría y discapacidad" en la que participaron Cuauhtémoc Medina, curador del

12 En México, la definición de discapacidad más comúnmente utilizada en diversos ámbitos es una oficial y coexiste con otros términos, en su mayoría importados, como diversidad funcional, capacidades diferentes, capacidades especiales, entre otros. Sin embargo, aún está pendiente un debate amplio, sobre todo desde el movimiento asociativo de personas con discapacidad, respecto a términos, sus definiciones y aplicaciones. 
Museo Universitario Arte Contemporáneo, Tania Aedo y Paloma Oliveira directora y museógrafa, respectivamente, del Laboratorio Arte Alameda. A partir del diálogo sobre el rol del curador/curadora en el promover tanto al artista como el generar una audiencia, se produjo un intercambio de opiniones y experiencias con artistas con discapacidad que dejó claro la necesidad de dos elementos básicos, un discurso más robusto y contundente sobre la singularidad del artista con discapacidad y de su producción; y, una unión de artistas que lograra armar dicho discurso, promoverlo y confrontarlo también. Aidan Moesby ${ }^{13}$, curador invitado al evento, planteó la importancia de recuperar el rol de la curaduría para preguntarse sobre la posición que el artista con discapacidad tiene en el circuito artístico y fuera de este. La interrogación por la curaduría es esencial para romper con el mito del que habla Siebers (2005) de un arte que se basa en una estética no-material y donde el cuerpo del artista pesa más que el cuerpo hecho arte.

Hay un modelo de curaduría tradicional que llamo "Trinidad de la discapacidad" de la curaduría. Este modelo ofrece poco al mainstream. Artistas con discapacidad son generalmente percibidos como poco profesionales, sin valor económico y sin valor en un contexto social o cultural. Probablemente son generalizaciones, pero son actitudes que yo he vivido. El contexto dicta el valor. [...] ¿Cómo, como artista con discapacidad logras tu trabajo de ser visto, hacerse público, frente a personas quienes poseen "agencia"? Los curadores son los centinelas de las galerías, la atmósfera enrarecida del cubo blanco. En mi experiencia los curadores son increíblemente difíciles de contactar. (Presentación en coloquio, jueves 28 de junio, 2018)

Frente a ello, Moesby planteaba, que el único camino para los artistas que producen desde la discapacidad es el unirse para romper el silencio

No necesitan silenciarnos si no usamos nuestra voz. (Moesby 2017)

Sin embargo, como lo argumentaron los artistas Ekiwah Adler, ${ }^{14}$ Carmina Hernández y Maricarmen Graue ${ }^{15}$ hay varias aristas que analizar al momento de cuestionar el llamado silencio de los artistas que crean desde la discapacidad, estas tienen que ver con barreras impuestas por un sistema educativo que limita

13 Aidan Moesby es artista y curador inglés que forma parte del consejo del festival Unlimited en Inglaterra. Su trabajo se centra en hacer visible el rol del curador con discapacidad, figura que es incluso más marginalizada que la del artista con discapacidad. Igualmente, su obra es una constante invitación a pensar en el papel del artista que se identifica con una discapacidad invisible.

14 Poeta y escritor con parálisis cerebral. Su escritura la ejerce en español y en inglés. Ver el link http://www.elem.mx/autor/datos/14980.

15 Compositora y chelista, para ver su obra https://maricarmengraue.wordpress.com/ acerca-de/. 
la formación de los mismos; interpretaciones y desinformación sobre la discapacidad que tienen tanto artistas como curadores que están dentro del circuito artístico; la falta de apoyo por parte del gobierno al campo artístico cultural en general y sobre todo al que se relaciona con la discapacidad; y, la fragmentación del movimiento asociativo de la discapacidad que también impacta en la falta de espacios para que dichos artistas puedan convocarse.

Ante estas demandas, los artistas invitados lanzaron la propuesta de crear un colectivo $^{16}$ que tendría que mirar hacia dos caminos, parafraseando a Siebers (2005) en un artículo escrito en memoria de Judith Scott, 1) establecer la discapacidad como marco crítico que cuestiona las presuposiciones subyacentes en las definiciones de producción y apreciación estéticas; 2) establecer la discapacidad dentro del arte como un valor significativo en sí mismo que necesariamente deberá desarrollarse en el futuro. Un colectivo constituido por artistas que se identifican con diversas discapacidades resuena desde el planteamiento del mismo Siebers de que la aceptación de la discapacidad enriquece y complica las nociones materialistas de la estética, mientras que el rechazo de la discapacidad limita las definiciones de ideas y objetos artísticos.

Argumentar que la discapacidad tiene un papel rico pero oculto en la historia del arte no es decir que la discapacidad ha sido excluida. Es más bien el caso que la discapacidad es rara vez reconocido como tal, a pesar de que a menudo sirve como factor que establece ciertas piezas artísticas como ejemplos superiores de belleza estética. La discapacidad ha servido para diferenciar entre arte bueno y malo, y no como uno lo esperaría. Es decir, el buen arte incorpora la discapacidad. Distinciones entre arte bueno y malo puede parecer problemático, pero solo si uno asume que los juicios críticos nunca son aplicados en el mundo del arte, una suposición insostenible. Mi punto, sostiene Siebers, es que la producción artística que argumenta cierta superioridad es aquella que tiende a reclamar discapacidad. Esta no es una fórmula absoluta, aunque algunos lo han argumentado, por ejemplo, Francis Bacon y Edgar Allan Poe, que escribió que "No hay una belleza exquisita, sin alguna extrañeza en su proporción ", o André Breton, quien exclamó "La belleza será convulsiva o no será en absoluto".

Es la presencia de la discapacidad lo que permite que la belleza de una obra de arte pueda soportar la crítica del tiempo. La propuesta de un colectivo generó a su vez una serie de preguntas sobre el arte, su normalización y el papel del artista, entre las que vale la pena rescatar:

16 El Colectivo adoptó el nombre de Colectivo Discreantes que hace referencia a la singularidad de sus miembros y a la crítica hacia la forma tradicional de entender al artista con discapacidad. 
- ¿Si un artista "con discapacidad" es siempre un artista o hay, como generalmente promueven ciertas organizaciones trabajando en el tema, que empoderarlo para que lo sea? ¿Cuál es el momento en que él o ella lo descubren? ¿o los fuerzan a descubrirse?

- ¿Qué detiene al artista a concebirse y circular como tal? ¿Cuánto de eso es la discapacidad? ¿Cuánto es un límite social o incluso subjetivo?

- ¿Cuál es la brecha entre lo que el artista quiere mostrar y lo que puede mostrar?

- ¿En qué medida desea el artista que su trabajo revele la discapacidad? ¿Hasta qué punto quiere que su trabajo la oculte?

- ¿Hasta qué punto es su trabajo sobre su discapacidad?

- ¿Dónde trabaja su obra?

- ¿En qué medida tener una audiencia es importante para su proceso?

- ¿Qué tan abierto estás acerca de compartir su proceso como artista con otros?

- ¿Cuál es el sentido de su arte?

- ¿Cómo le sirve su discapacidad en su proceso como artista?

- ¿Qué necesita para alimentar su discapacidad a fin de convertirla en un aliado en su proceso como artista?

- ¿En qué punto ser artista se vuelve insoportable? ¿en qué punto tener discapacidad se vuelve insoportable para ser artista?

\section{4 "Aliados": el rol de 17, y de otros en el proceso}

La plataforma ofrecida por 17, para la formación y fortalecimiento del colectivo dio paso a interrogarnos sobre el papel que tendríamos, conocedores que nuestro principio de trabajo con personas con discapacidad, o con cualquier otro grupo que ha sido socialmente marginado, responde a la premisa de "Nada sobre nosotros, sin nosotros" (Charlton 1998) o parafraseando a la activista holandesa Jaqueline Kool "nada sin nosotros, punto" (2014). En esto, Morris (1992) señala que cualquier grupo que se siente oprimido necesita de aliados para avanzar en su emancipación y que en el campo de la discapacidad, académicos e investigadores tienen dos roles como aliados: 1) reconocer y retar la discriminación hacia las personas con discapacidad, a través de involucrar en todos los niveles a las mismas; 2) si los académicos o investigadores dedican su trabajo a la discapacidad, deberán preguntarse cómo lo realizan, cuál es su relación con las personas y que entienden por discapacidad, todo ello con el fin de impulsar los procesos de emancipación de las personas con discapacidad. 
El trabajo traducido en un diálogo con artistas y curadores a partir del coloquio fue posible llevarlo a cabo, también, gracias a la interlocución con personas y académicos involucrados en el campo del arte y la curaduría que habían o no incorporado a la discapacidad entre sus líneas de trabajo. El diálogo con Tania Aedo, Paloma Oliviera y Nancy Viva Halifax ${ }^{17}$ permitió una discusión sobre los elementos planteados por Morris que fueron cuestionando la práctica llevada a cabo en la organización del coloquio y los efectos poscoloquio. Un ejemplo, que incluye preguntas por el rol de los aliados, de los curadores y de los artistas, es la muestra colectiva "De la norma al nombre"18 que se realizó paralela al coloquio, así como otras actividades que incluyeron conversatorios y exhibiciones ${ }^{19}$, que tuvieron como centro de ejecución el Laboratorio. Cada evento significó un ejercicio de negociación y reflexión entre las diferentes partes, lo cual fue permitiendo la creación de conocimiento valioso tanto para los artistas con discapacidad y para los aliados. Este proceso, no estuvo exento, por supuesto, de momentos de tensión que surgieron junto con el reconocimiento que dicha tensión es parte del rechazo a formas tradicionales de trabajo que restan valor a la producción de conocimiento desde la discapacidad y que ponen en evidencia luchas de poder entre llamados expertos, académicos, y personas con discapacidad. Goodley ${ }^{20}$ refiere al respecto que

Nuestra posición como investigadores que deseamos ser aliados de las personas con discapacidad, pero que estamos situados en un contexto que nos obliga a contribuir a la construcción de una disciplina respetable, presenta dificultades reales. Podemos desear avanzar en la comprensión de la política de la discapacidad, pero también estamos obligados a mantener una posición definida en la academia. Hay paradojas incorporadas. (Goodley 1998: 40)

17 Académica, activista y artista con discapacidad canadiense. Para más información http://health.info.yorku.ca/health-profiles/index.php?mid=502554.

18 La muestra incluyó 13 piezas de los artistas Diana Cano, Ana García, Carmina Hernández, Pedro Miranda y Sueli y se realizó en el Centro Cultural Brasileño y fue curada por Paloma Oliveira. Para más información https://www.pressreader.com/.

19 Se realizó la exhibición "Arqueología de la autonomía" que incluyó las piezas de artistas sordos y diálogos con personas con discapacidad y académicos sobre el concepto de la autonomía y otros relacionados. Fue curada por Tania Aedo y Paloma Oliviera. Paralelamente, hubo talleres sobre arte, curaduría y discapacidad así como un ciclo de cine foro. Para más información https://www.inba.gob.mx/prensa/10628/arqueologia-de-la-autonomiauna-reflexion-sobre-lo-que-somos.

20 Goodley, Dan (1998). "Supporting people with learning difficulties in self-advocacy groups and models of disability", en: Health \& social care in the community, 6 (6): 40. 
La invitación a mirar en 17, un espacio de iniciación y experimentación ha dado paso al planteamiento de ciertas acciones, entre ellas el hacer seguimiento a prácticas efectuadas desde museos y galerías en el país. La ausencia de una crítica artística respecto a lo que se produce y se exhibe en relación a la discapacidad demanda la intervención del colectivo. Dicha crítica deberá ser orientadora y generadora de procesos distintos en las instituciones culturales. Otra acción propuesta es la del trabajo en red de una manera libre y horizontal. Es decir, cuidando que no se repliquen prácticas jerárquicas y divisorias llevadas a cabo en otras instancias culturales y artísticas. Lo cual permitirá hacer evidente la reflexión que se mantiene respecto al aporte singular que los artistas con discapacidad pueden hacer al ejercicio del arte en general. Aún hay un camino por recorrer en esta búsqueda de aliados por desconstruir lo que se entiende como arte producido desde la discapacidad y la posición en la que se ubica la figura del artista. El trabajo colectivo para pasar de la norma al nombre sin duda ofrece la posibilidad de crear y producir conocimiento que beneficiará, sin duda alguna, a la comunidad en general.

\section{Conclusiones}

La apertura de un espacio de reflexión, diálogo y performance dio como resultado el nacimiento de un colectivo que a través de la producción y creación artística se constituye en una esperanza para la reinvención del movimiento asociativo de personas con discapacidad en México. El coloquio realizado por 17, Instituto de Estudios Crítico junto con Laboratorio Arte Alameda, permitió experimentar con formas de alianzas y de acompañamiento a artistas con discapacidad. El futuro de este tipo de alianzas está en manos tanto de instituciones académicas, artísticas y culturales, como de las personas y artistas con discapacidad. Pasar de la norma al nombre, es decir de la tradicional forma de entender al arte, al artista y su vinculación con la discapacidad exige un diálogo entre sectores y entre personas con diversidad de discapacidades. Dicho proceso involucrará también la reflexión crítica de conceptos, definiciones y metodologías de trabajo. Al final, lo que se espera, es que el conocimiento de diversos grupos y sectores puesto en diálogo, cree propuestas que contribuyan a la emancipación de una sociedad normalizada y capacitista. 


\section{Bibliografía}

Bauman, Zigmund. 2004. Identity: conversations with Benedetto Vecchi, Cambridge: Polity Press.

Charlton, James. 1998. Nothing About Us Without Us, Berkeley: University of California Press.

Davis, Lennard. 2002. Bending Over Backwards: Disability, Dismodernism, and Other Difficult Positions, New York: New York University Press.

Goodley, Dan. 1998. "Supporting people with learning difficulties in selfadvocacy groups and models of disability", en: Health \& social care in the community, 6 (6): 438-446.

Kool, Jacqueline. 2014. Eros in de kreukels. Verhalen over lijven, leven, en lust vanuit de kreukelzone, Holland: Stichting Kreukelzone.

Mayer Foulkes, Benjamín. 2014. “El fotógrafo siega”, en: Benjamín Mayer Foulkes (comp.), El fotógrafo ciego. Evgen Bavčar en México, Colección Diecisiete (6): 17 , Conaculta.

Moesby, Aidan. 2017. “Where are the disabled Curators?", en: Disability Arts Online (Nov., $9^{\text {th }}, 2017$ ), https://disabilityarts.online/magazine/opinion/whereare-the-disabled-curators/ [25-10-2019].

Morris, Jenny. 1992. "Personal and political: a feminist perspective on researching physical Disability”, en: Disability, Handicap \& Society 7 (2): 164-165.

Shakespeare, Tom. 2006. Disability rights and wrongs, London: Routledge.

Siebers, Tobin. 2005. "Disability aesthetics", en: PMLA 120 (2): 542-546.

Siebers, Tobin. 2010. Disability aesthetics, Ann Arbour: The University of Michigan Press.

Solvang, Per Koren. 2012. "From identity politics to dismodernism? Changes in the social meaning of disability art", en: ALTER, European Journal of Disability Research (6): 178-187.

Turner, Janice. 2005. "But what do the pigeons think of her?", The Times 9 (17), https://www.thetimes.co.uk/article/but-what-do-the-pigeons-think-of-herlz893d5cvqc [25-10-2019]. 



\title{
Patricia Brogna \\ Universidad Nacional Autónoma de México \\ Plemya: regresando a la tribu
}

\begin{abstract}
This article analyzes the Ukrainian film Plemya (The tribe). This film is about the daily life of a group of Deaf youngs inside of a school. All the dialogues in the movie are carried out in Ukrainian Sign Language without subtitles or any oral translation. This Director's decision, as well as the questions that arise from the interpretative analysis of the movie's aesthetic and semiotic nature, besides the cinematographic language (image, sound, montage, staging, and narration), makes Plemya a fractal metaphor of the social context. A metaphor which is based meaningfully on a particular group inside of society: these young Deaf persons in a situation of institutionalization.

Identifying these inherent aspects of the cinematographic work is the trigger that allows a social analysis about disability, understood through the crossroads model as a space in the social field that is constituted by the confluence of three aspects, overcoming the individual notion of the deficit. In the temporal cut in which the script is developed, we witness the multiple stories that are connoted, the lives over which we take an ignorant conscience. Miroslav Slaboshpitsky achieves, with this stark story, to move the spectator about those strangers with whom we do not want to identify ourselves and whose history we peek into from an aseptic and protective distance.
\end{abstract}

Keywords: The tribe, Ukrainian film, disability, deaf people

\section{Introducción}

\footnotetext{
"Ya todo está" en el reservorio del inconsciente colectivo, almacenado en esos grandes generadores de símbolos que son los arquetipos, y cuando el grupo regresa al estado mental que le debe ser el más familiar, ya que vivió en él millones de años, vuelven a surgir las imágenes arcaicas, eternas, y con ellas "inventa", "descubre", "recuerda" los mitos.
}

Raúl Usandivaras

La película Plemya ("La tribu") es el primer largometraje del director ucraniano Miroslav Slaboshpitsky. Estrenada en 2014, tiene como antecedente el cortometraje "Sordera", que el mismo director realizó en el año 2010. En este corto se pueden identificar aspectos que Slaboshpitsky retoma luego en "La Tribu": los diálogos en lengua de señas ucraniana sin subtitulado, el lenguaje visual, la 
estética, el ambiente sórdido, la violencia, las figuras de autoridad como instancias ausentes, peligrosas o amenazantes.

La síntesis del guion de Plemya resulta una empresa compleja sino imposible: en La tribu se cuentan múltiples historias y cualquier intento de reducirlas a una historia lineal y única, a una sucesión de secuencias que diera sentido al sinsentido quedaría en deuda con la propuesta fractal que hace Slaboshpitsky y se transformaría en un resumen siempre parcial. Ello queda en evidencia al leer las diferentes sinopsis, entre la que, a modo de ejemplo, transcribimos la publicada con motivo de su exhibición en la Cineteca Nacional de México:

Esta opera prima narra la llegada del adolescente Serguéi a un internado para jóvenes sordos, donde todo parece transcurrir con normalidad. Sin embargo, después de atravesar una serie de pruebas de iniciación, Serguéi se enfrentará a la realidad profunda de la escuela, donde los robos y la prostitución son coordinados por el chico más violento del lugar. En sintonía con la ausencia de palabras de sus personajes, La tribu es una película que logra conducir al espectador por una poderosa narrativa corporal y pictórica. ${ }^{1}$

\section{La discapacidad, como categoría de análisis}

La discapacidad supera el déficit individual, el diagnóstico, la "patología asociada a la desviación de una norma" para configurarse como posición en el campo social, entendida como "la posición ocupada en el espacio social, es decir en la estructura de distribución de las diferentes especies de capital que asimismo son armas, ordena las representaciones de ese espacio y las tomas de posición en las luchas para conservarlo o transformarlo" (Bourdieu 2007: 25).

Desde una perspectiva relacional y compleja esta posición se configura, según el modelo de la encrucijada (Brogna 2009: 168-169), en la confluencia de tres factores que interactúan de tal manera que no son aislables y que solo pueden ser definidos en función del resto: la particularidad biológica-conductual de un sujeto (individual o colectivo); la organización económica y política y el componente cultural-normativo del grupo o sociedad a la que ese sujeto pertenece. Gráficamente:

1 Fuente: https://www.cinetecanacional.net/micrositios/foro35/detalle.php?id=13654 [19-04-2019]. 


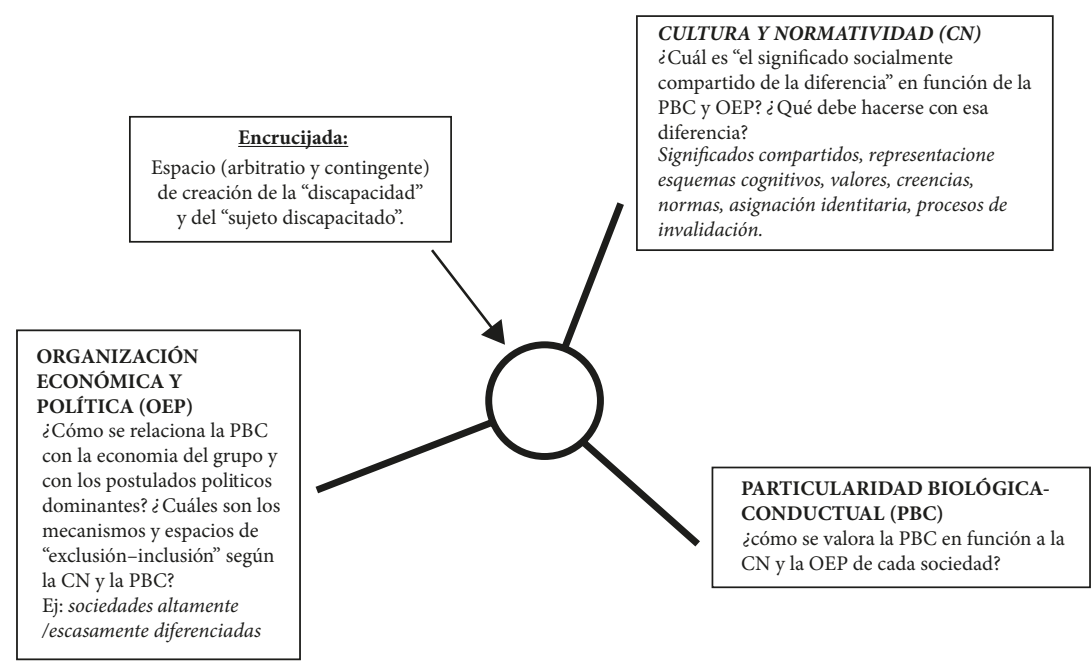

Puede entenderse que a lo largo de la historia los sucesivos cambios en los componentes de la encrucijada modificaban la posición de discapacidad, los parámetros sobre aquellos sujetos a quienes se les asignaba la posición así como el trato que debía dárseles. Las diferentes visiones históricas a las que refiere el modelo a partir del análisis de las diferentes circunstancias, no se suplantan sino que se superponen, se solapan con las anteriores en una coexistencia que responde a la totalidad espacial y temporal referida desde la teoría de sistemas no lineales y la perspectiva epistémica de la complejidad.

\subsection{El componente referido a la organización económica y política}

La historia de Ucrania y el contexto político durante la filmación de ambas películas son aspectos prioritarios a considerar: telón de fondo y fantasmas que enmarcan y recorren, respectivamente, ambas historias. "Sordera" se filma entre el período de la Revolución Naranja durante la que se desarrollaron protestas, denuncias de corrupción y fraude electoral, con votaciones anuladas, presencia de observadores internacionales y la alternancia de gobiernos de tendencias prorrusas y proeuropeas. Sobre el contexto de "La tribu" Santos et al. (2018: 83-84) refieren: 
Todos los adolescentes del film son sordos y "La tribu" fue su primera experiencia como actores. Slaboshpytskyi pidió ayuda a la Asociación Nacional de Sordos de Ucrania para promocionar las audiencias del casting. Participaron más de trescientos adolescentes de Ucrania, Rusia y Bielorrusia. Las filmaciones se realizaron en Kiev en un momento de gran tensión política: la Revolución de Ucrania, también llamada Euromaidan había comenzado en noviembre de 2013. El movimiento civil que llevó a la caída del presidente Viktor Yanukovytch exigía una mayor integración con Europa a través de la adhesión de Ucrania a la Unión Europea. El clima de tensión política continúo hasta el final del rodaje, cuando ocurrió la Crisis de Crimea, una reacción a los acontecimientos en Kiev por parte de los rusos que defendían una integración con Rusia o incluso la independencia de la región de Crimea y, que culminó con la invasión por el ejército ruso en la región. "Filmé en una atmósfera dentro del país en que cada instituto, cada institución social, cada gobierno operaba en un principio como de un grupo mafioso, la atmósfera que se daba también entre algunos contrarios a la revolución" (YAMATO 2015). El bloqueo de calles afectó el rodaje e incluso el protagonista Grigoriy Fesenko (Sergey) participó en las protestas en Kiev durante las filmaciones.

En la entrevista publicada por El Diario, Slaboshpitsky relativiza el grado de ficción que se expresa en la trama:

"La historia es su conjunto es ficción. Pero todas las escenas, por individual, están basadas en situaciones reales de personas con discapacidad [...]". La "mafia de la sordera", como él la llama, es un problema todavía vigente en Rusia y en su país, donde los explotadores se aprovechan de una comunidad desprotegida por la ley ucraniana. (Zas Mar$\cos 2016)$

La atmósfera de desprotección que acompaña el desarrollo de las historias envuelve a personajes atrapados en una maraña de grupos mafiosos y de prácticas corruptas que Slaboshpitsky pone en palabras en el párrafo anterior, pero que muestra durante las escenas de ambas obras. Sin embargo es en el largometraje donde ese abandono se despliega con total ferocidad: tanto las situaciones de corrupción institucional, la anomia generalizada en la que los delitos se naturalizan (la trata de mujeres, la prostitución de menores, la distribución de droga), como el ambiente de violencia que respiramos de manera creciente a lo largo de todo el film y que presagia la inminencia de la fatalidad, son expuestos sin piedad ni condescendencia a través de una lógica narrativa implacable.

Plemya se estrena apenas 23 años después de la declaración de independencia de la República Socialista Soviética de Ucrania en el marco de la disolución de la URSS. En esta etapa postsoviética, Ucrania se debatía durante los meses de filmación entre un nuevo acercamiento político con Rusia o en avanzar para su participación en la Unión Europea-UE. Actualmente el país es considerado por la UE en las políticas de "buenos vecinos" y a través de la firma de un Acuerdo 
de Asociación que entró en vigor en 2017, promueve como primer paso el acercamiento comercial:

[...] vínculos políticos más profundos, vínculos económicos más fuertes y el respeto de los valores comunes. La zona de libre comercio de alcance amplio y profundo (ZLCAP) es la parte económica del acuerdo. Ofrece un marco para la modernización de la economía y las relaciones comerciales de Ucrania. ${ }^{2}$

\subsection{El componente referido a la cultura y la normatividad}

Leída en clave de procesos macrosociales, La tribu permite un acercamiento a las visiones sobre la discapacidad, en especial la visión caritativo-represiva, así como abona a la comprensión de los factores culturales que inciden en el modo en que se configura la encrucijada: el capacitismo que -junto con el racismo, el antisemitismo, el clasismo y el sexismo (Adams et al. 2000: 461-496)- rechazan la presunción de igualdad entre las personas, con base -en este caso en particular- en criterios de capacidad o funcionalidad. Según Karen y Bárbara Field además de "racismo" ("como discursos y prácticas sociales, jurídicas, políticas e institucionales") se debe considerar la racialidad, - "racecraft" - ("como el repertorio de maniobras destinadas a situar a los seres humanos así diferenciados en celdas operativas") tal como explica Mbembé (2016: 25-81).

Para el año 2014, y a partir de la Convención sobre los derechos de las personas con discapacidad se habían plasmado en el contexto normativo de la Unión Europea los postulados que iniciaron como un gran cambio cultural, a partir de las demandas del movimiento social de las personas con discapacidad en la década de los '60. Sin embargo, las repúblicas socialistas soviéticas estaban bajo la visión rusa basada en la disciplina que aún llaman "defectología". Por lo tanto la posición de discapacidad en el campo social responde a la confluencia de estos aspectos, aislados en lo espacial y lo temporal de los cambios y cuestionamientos que se produjeron en otros contextos, aún dentro de Europa.

Como parte de estos cuestionamientos y en un intento por tomar distancia del término "discapacidad" - como déficit individual- surge en España el concepto de "diversidad funcional". Javier Romañach, reconocido activista y líder del movimiento de Vida Independiente, en una entrevista realizada en el año 2008, narra el momento en el que asumió la necesidad del término y la pretensión que tuvo al desarrollarlo, anteponiendo la diversidad como referencia a la condición universal de lo humano.

2 Fuente: https://www.consilium.europa.eu/es/policies/eastern-partnership/ukraine/ [19-04-2019]. 
Lo que pasa es que cuando hablas de diversidad funcional, la gente no sabe si está o no está, pero el que se siente dentro sí sabe que está.

Entonces uno de los esfuerzos del término es generalizar, que todo mundo se sienta parte de..., a la vez que pones la barrera de discriminación. [...] la pretensión teórica es que todo mundo se sienta identificado, que haya un doble juego de barrera y globalidad, es un poco complicado porque es difícil de explicar.

Reconozco que es un poco sutil todo esto, en un mundo en que todo tiene que ser blanco o negro. Y esto de intentar globalizar o de incorporar a toda la sociedad a la par y a la vez hacerla consciente de que hay personas que son discriminadas por algo que todo mundo quiere (la diversidad)... es un lenguaje complicado. ${ }^{3}$

\subsection{El componente referido a la particularidad biológica y de conducta}

Las personas con discapacidad auditiva, en especial aquellas personas que nacen sordas, forman parte de un colectivo que -en algunos países- ha confrontado fuertemente los otros componentes de la encrucijada, asumiéndose como parte de una comunidad Sorda con una cultura y una lengua propia. Sin embargo han recibido un trato de sometimiento y opresión a través de lo que Lane (1992) llama "la máscara de la benevolencia" incluyendo la colonización de su modo de comunicarse al imponer la oralización como método educativo-terapéutico. Abberley señala que:

[...] afirmar que las personas con discapacidad están oprimidas implica afirmar una serie de puntos adicionales. En el nivel empírico significa afirmar que en general, se encuentran en una posición inferior a la de otros sujetos de la sociedad, simplemente por tener discapacidad. También implica afirmar que esas desventajas están relacionadas con una ideología que justifica y perpetúa esa situación. Además, también significa aseverar que dichas desventajas y las ideologías que las sostienen no son ni naturales ni inevitables. Finalmente conlleva la identificación de algún beneficiario de esa situación. (2008: 37)

En el contexto político, económico, cultural y normativo en el transcurre Plemya, la posición asignada a las personas sordas, particularmente aquellas que están institucionalizadas en espacios de autoridad simulada y sin más referencia que los grupos de los que forman parte de manera coyuntural y eventual, los posiciona en un espacio social de extrema vulneración y riesgo.

3 La entrevista forma parte de la investigación doctoral: "Condición de adulto con discapacidad intelectual posición social y simbólica de otro" (2012, 43-48). En el Anexo 1 se incluye el apartado completo de la entrevista, su análisis e interpretación. 


\section{Plemya: el guion, las historias}

"La tribu" inicia con la llegada de un "extranjero", un extraño que arriba a la ciudad y a la institución: una escuela para sordos, con el recibimiento inaugural y los discursos previos a lo que parece ser un nuevo ciclo de clases. Sergei se incorpora al piso donde viven los estudiantes mayores, un espacio abandonado por la autoridad, en el que si bien existe un grupo que lidera, es la persona que los supervisa -como se irá percibiendo a lo largo del desarrollo de la trama- quien permite la venta de drogas y fomenta la explotación sexual de las alumnas en parques y estacionamientos de tráileres del mismo modo que gesta la posibilidad de su trata a Italia.

Las relaciones sexuales entre el protagonista y una de las jóvenes, el vínculo de mayor cercanía entre las dos mujeres muestran algunas de las escasas escenas que evidencian afectuosidad, dentro de la soledad y las estrategias de sobrevivencia que cada joven despliega para una vida sin futuro que se juega permanentemente en el ahora.

Plemya termina con una imagen opuesta a la inicial: el joven que llegó al internado, en la escena final cierra la puerta ante nuestra mirada impotente yéndose, quizás huyendo, sin angustia, sin urgencia y sin ira, como si la muerte no fuera algo nuevo para él. Antes y después de los sucesos que se muestran, él no tiene historia.

Desde las primeras escenas Slaboshpitsky descentra al espectador al enfrentarlo con diálogos en lengua de señas ucraniana sin subtitulado y lo confronta, de este modo, con su propia imposibilidad de entender, con la falta, con la ausencia de una habilidad que lo inscribe también como un extraño, como un extranjero. Luego de esta primera y radical demanda de "disposición activa del que mira", se van construyendo procesos de discernimiento: el espectador prontamente sabe qué sucede y se concierne, se conmueve con las situaciones que se muestran de manera explícita o connotada. Un testigo que no puede regresar a la ignorancia.

\section{Entendiendo a la tribu}

A partir del análisis interpretativo e instrumental (Zabala 2010a: 65-66) se evidencian diferentes aspectos del film. A través del análisis interpretativo se aborda la naturaleza estética y semiótica de esta obra transformada en una alegoría de lo social, en un doble sentido. En primer lugar, Plemya es el signo que articula violencia, sometimiento, en un contexto global de individualización -individua-

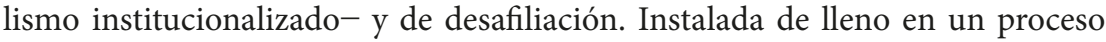
de globalización económica, social y cultural, Ucrania está fuera de las órbitas 
plenas de Rusia y Europa aunque mantiene aún prácticas de jerarquías burocráticas rígidas sostenidas en un entramado extenso de corrupción y delincuencia organizada ${ }^{4}$. En la transición entre dos mundos, Ucrania no pertenece plenamente a ninguno de los dos: es también una extranjera. Los jóvenes de la tribu, representan a una humanidad que aún bajo la promesa de pertenecer a un "mundo feliz", no puede menos que asumir, que reconocer la desigual posibilidad de ver cumplida esta promesa. Migraciones desde países devastados, la individualización exacerbada en las "biografías hágalo usted mismo" que destruye los fundamentos de la coexistencia social y "desincrusta sin reincrustar" (Beck y Beck-Gernsheim 2003: 30-40), la "desafiliación" (Castel 1997: 142)5 que sufren "los supernumerarios"6 (1997: 335-350), entendida como la zona en la que los sujetos dejan de estar inscriptos en toda estructura social dadora de sentido. En segundo lugar, la discapacidad está presente en Plemya en diferentes niveles: en la condición real de sordos de los jóvenes actores no profesionales; en el nivel de representación de sordos, en cuanto personajes; como miembros de la comunidad sorda y como fuente, ya que Slaboshpitsky retoma situaciones concretas que le fueron narradas por sordos. Se identifican en la historia, las circunstancias de exclusión, sometimiento, opresión y violencia que las personas con discapacidad sufren de manera recurrente en sus trayectorias de vida. Así, aun cuando se

4 Tasa de la delincuencia organizada según los datos del ranking Foro Económico Mundial. Fuente: http://reports.weforum.org/global-competitiveness-index-2017-2018/ competitiveness-rankings/\#series=EOSQ035 [19-04-2019].

5 De allí la posibilidad de construir lo que yo llamaría metafóricamente "zonas" de cohesión social. Entonces, la asociación "trabajo estable/inserción relacional sólida" caracteriza una zona de integración. A la inversa, la ausencia de participación en alguna actividad productiva y el aislamiento relacional conjugan sus efectos negativos para producir la exclusión, o más bien, como trataré de demostrarlo, la desafiliación. La vulnerabilidad social es una zona intermedia, inestable, que conjuga la precariedad del trabajo y la fragilidad de los soportes de proximidad. (....) El concepto [desafiliación] pertenece al mismo campo semántico que la disociación, la descalificación o la invalidación social (Castel 1997:13-14).

6 "Ellos ocupan una posición de supernumerarios, flotan en una especie de tierra de nadie social, no integrados y sin duda inintegrables, por lo menos en el sentido en que Durkheim habla de la integración como pertenencia a una sociedad formada por un todo de elementos inter-dependientes. Esta inutilidad social los descalifica también en el plano cívico y político. A diferencia de los grupos subordinados de la sociedad industrial, explotados pero indispensables, estos no gravitan en el curso de las cosas" (Castel 1997: 245-246). 
conviertan en violentos opresores, no dejan de ser tiranos de la propia celda ya que no tienen posibilidad de revertir las condiciones que determinan su posición.

Los términos referidos en los párrafos anteriores, así como los referidos a Adams y Field, apuestan a quedar inscritos dentro de propuestas políticas, teóricas y conceptuales que respondan a posicionamientos críticos y decoloniales, abrevando de debates y aportes del feminismo, de la negritud y la perspectiva queer y de género, deconstruyendo la condición de los sujetos como sustento de una alteridad inherente.

Arte y artificio de construir al "otro", cada práctica, cada discurso lleva en sí el germen de una ficción peligrosa: asumir que el otro en realidad existe. En términos de Foucault:

Me parece que existe la posibilidad de hacer funcionar la ficción en la verdad; de inducir efectos de verdad con un discurso de ficción, y hacer de tal suerte que el discurso de verdad suscite, "fabrique" algo que no existe todavía, es decir, 'ficcione'. (1992: 172)

Según Santos "todo en el film parece contribuir para crear una distancia emocional entre el espectador y los personajes. Los elementos fílmicos están allí para

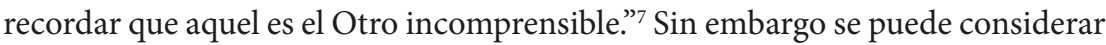
que esta distancia es un reto, una provocación de Slaboshpitsky quien nos interpela a través de una brecha que nos conmina a cerrar, reflexiva y activamente. Es en este sentido en el que Plemya demanda la acción racional y sensible del espectador: deconstruir esta ficción de otredad de los personajes reconociéndose e identificándose en las precarias condiciones que sostienen la vulnerada humanidad de los personajes.

Todos estos factores se anudan en la discapacidad, entendida como un constructo sociohistórico y político. Sobrevuelan la trama, se evocan en las escenas, se sienten en las emociones que despiertan, en las preguntas que provocan, en las respuestas que no satisfacen.

Como últimas cuestiones relacionadas al análisis interpretativo de los componentes del lenguaje cinematográfico (imagen, sonido, montaje, puesta en escena y narración) en La tribu el lenguaje visual se construye con planos generales y planos secuencia. La cámara transforma al espectador en un observador que -a través de la inacción involuntaria que se le asigna desde su anónimo lugar en la

7 "Tudo no filme parece colaborar para criar uma distância emocional entre espectador e personagens. Os elementos fílmicos estão lá para lembrar que aquele é o Outro incompreensível seja ele de outra etnia, portador de desabilidade, adolescente rebelde, criminoso ou de qualquer outra tribo." (Traducción propia) 
sala a oscuras- deviene en un testigo omnipresente e impotente. El ambiente de violencia, de peleas, hostilidad, maltratos, abuso, falta de afecto y de riesgo amenazador acompañan la luz, las penumbras y las sombras bajo las que transcurre la historia. Narrada a través de un discurso parco, realista, sin artificios, ausente de música, con sonido ambiente y en que la voz resuena gutural y primitiva, la historia nos reta a no conformarnos con la superficie, con la piel evidente y obvia del sentido inmediato.

El análisis instrumental, por otro lado, utiliza a las películas para fines específicos y recurre a métodos de análisis externos a la teoría del cine: la efectividad (en términos de producción, distribución y consumo), la utilidad (en términos prácticos), el valor (estudio de contenido). Desde este análisis Plemya encuadra en un cine no comercial, aunque ha cosechado premios y reconocimientos en diferentes festivales (Cannes, Londres, San Pablo, Tarragona) y asume contenidos poco recurrentes: el tratamiento que da a las situaciones que viven los jóvenes con discapacidad dista del trato condescendiente y lastimero, remarcando de manera descarnada la múltiple opresión social que se ejerce sobre este grupo ya que, como mencionaba Slaboshpitsky en párrafos superiores, la historia es ficción pero cada escena está basada en situaciones reales.

En lo referente al discurso van Djik identifica en ese concepto tres "dimensiones principales: a) el uso del lenguaje; b) la comunicación de creencias (cognición) y c) la interacción en situaciones sociales". "La mayor parte de los estudios del discurso se desenvuelve en alguno de los ámbitos descriptos hasta ahora o en varios de ellos a la vez: la forma, el sentido, la interacción y la cognición" aunque -resalta - el contexto desempeña un papel fundamental. Tal como menciona el autor, "en todos los niveles del discurso encontramos entonces 'huellas' de un contexto en el que las características sociales de los participantes desempeñan un papel fundamental, se trate del género, la clase, la filiación étnica, la edad, el origen, la posición u otros rasgos que determinan su pertenencia a un grupo" (2000: 21-65).

Como mencionábamos, al ser confrontado con una lengua que no comprende, el espectador debe tomar un papel activo para desentrañar: no "se deja" contar una historia, debe construirla, unir las piezas, interpretar las situaciones, significar, asumir los sentimientos que despiertan en él, entender y entenderse. Se asombra prontamente de la inutilidad de la palabra hablada y del innecesario dominio de una lengua de señas que, de conocerla, le aportaría detalles respecto a lo que percibe a través de otras formas de lenguaje prerreflexivas: el lenguaje corporal y gestual, el diálogo tónico. Es la articulación de estos lenguajes lo que suma dramatismo: estamos ante una historia que acontece de manera sincrónica en y entre los cuerpos. No transcurre en la discursividad temporal de la 
oralidad, en el devenir de la voz humana, en la narración diacrónica de la palabra hablada. Por el contrario, los "parlamentos" ocurren, se manifiestan de manera total frente a nosotros. Sin conceptos, sin racionalización, sin logos. Lenguajes y corporalidad de la violencia, el abuso, el sometimiento, la crudeza, la soledad y el abandono.

La segunda dimensión de van Djik, las creencias que se comunican a través del discurso, se tensionan desde los múltiples y contradictorios sentimientos que la película despierta. Una comprensión atravesada por la emoción, basada en ella. Un grupo de jóvenes sordos sometidos a un submundo de marginalidad, como identidad de un grupo al que no pertenecemos, transforma al espectador en una metáfora del ajeno. Sin embargo las creencias sobre la discapacidad, la delincuencia, la escuela, la autoridad del adulto, la ley pierden su sentido como categorías resultantes de un "deber ser". Los juicios morales son puestos a juicio en Plemya.

Sobre la dimensión de las interacciones sociales se identifican fácilmente la situación de abandono y deterioro (edilicio, humano, pedagógico) de esta institución total. Según Goffman (2004: 13) "una institución total puede definirse como un lugar de residencia y trabajo, donde un gran número de individuos en igual situación, aislados de la sociedad por un período apreciable de tiempo, comparten en su encierro una rutina diaria, administrada formalmente. Las cárceles sirven como ejemplo notorio, pero ha de advertirse que el mismo carácter intrínseco de prisión tienen otras instituciones, cuyos miembros no han quebrado ninguna ley." En su análisis distingue cinco grupos: las de cuidado -en el doble sentido de la visión caritativo-represiva: aquellos a quienes hay que cuidar o de quienes hay que cuidarse (Brogna 2009: 177-179)-, de castigo, las formativas-laborales (escuelas, barcos, colonias) y los "refugios del mundo" abadías, monasterios (Goffman 2004: 18-20).

El espacio donde los jóvenes viven adquiere en la historia una multiplicidad simbólica. La escuela es a la vez un ámbito de encierro, de aislamiento, un castigo que antecede al delito. Los jóvenes permanecen en el internado casi todo el día y habitan de manera marginal -generalmente en las noches- otros "no espacios": parques desiertos, tiendas de paso, aparcamiento de camiones. Las historias que se trenzan en "la tribu" son un texto a leer sobre el contexto de la violencia política, la corrupción y las prácticas mafiosas en la Ucrania de Plemya, y en el contexto del sentido dado a la discapacidad en general y a la sordera en particular.

La historia transcurre entre el arribo de Sergei a la ciudad, su llegada al internado y su partida, cuando traspasa y -ya invisible- cierra la puerta ante nuestra mirada. El sonido del cerrojo es la escena final. De manera fractal, si inscribimos 
la historia en un contexto cada vez más amplio, tanto en la condición de discapacidad, como la vida de los personajes en situación de cuasi encierro, la del propio internado como institución en abandono, la de los grupos mafiosos que utilizan a jóvenes sordos para actividades delictivas, en una sociedad que está rearmando sus vínculos políticos y sociales son aspectos que se resignifican en su propio entrelazamiento, que se contienen y ocultan como las figuras de las matruskas rusas. Recordando a la primigenia etapa de communitas (Usandivaras 1982: 57), al estado liminal en el cual el contraste entre estar dentro o fuera transforma a un lugar en un "espacio sagrado", donde trascurren los ritos, las ceremonias y los sacrificios, tanto la tribu como su guarida se invisten de ese estatus.

De este modo el aspecto del sentido adquiere en La tribu un carácter simbólico de desgarradora metáfora: la juventud, la sobrevivencia, la falta de ley y autoridad, la marginalidad, el abandono, las relaciones, el desamor están expuestos con tal crudeza, que su aséptica enunciación se completa en la huella, en la impronta emocional que deja en el espectador. En la Lógica del sentido (2005: 54-63), Deleuze relaciona sentido y sinsentido refiriendo que el sentido nunca está solamente en uno de los dos términos de una dualidad; que uno se instala "de golpe" en el sentido y que este es un elemento paradójico como perpetuum mobile, nunca está donde se lo busca y no se lo encuentra donde está: "Falta a su lugar". El sinsentido es a la vez palabra y cosa, doble cara, exceso y defecto, casilla vacía y objeto supernumerario; lugar sin ocupante y ocupante sin lugar. Bajo estos preceptos La tribu expone el sentido-sinsentido de la humanidad, lo hace visible en su vacancia, lo denuncia con su ausencia: en las búsquedas infructuosas de un vínculo humano, en la expectativa de un futuro, en condiciones sociales y políticas que recuperen la aspiración arquetípica y tribal de construir comunidad.

\section{ANEXO}

Entrevista a Javier Romañach sobre el término "diversidad funcional” (Brogna 2012: 43-48).

Durante la entrevista realizada al activista con discapacidad Javier Romañach en España, nos explica el origen y pretensión del concepto "diversidad funcional".

Christian Courtis - a partir de una conferencia en la Universidad Carlos III, en noviembre del 2004- mencionó que éramos el único colectivo conocido que luchaba contra la discriminación y que se describía a sí mismo de forma negativa. Yo, cuando escuché esa conferencia en el foro, dije "aquí tenemos un problema", y llamé a un amigo y le dije "tío, me acaban de decir una verdad como un piano y aquí vamos nosotros de activistas, defendiendo algo negativo"; esto 
tiene que tener una solución. Nos pusimos a darle vuelta como cuatro meses y hasta que se nos pareció este, el mejor de todos los que habíamos barajado... ¡Se me ha ocurrido un día que iba por la calle! "Diversidad funcional" ¿funciona o no funciona? Al principio nos costó que entendieran el término “¿por qué diversidad funcional?” ¡bueno! Diversidad: diferencia, diversidad significa diferencia, porque diferentes somos.

Era parte (el concepto) de otro modelo, un modelo latente, no basta con cambiar las palabras, y el modelo social no es suficiente, hay que cambiar más. Yo que vengo del mundo de la bioética veía clarísimo que el modelo social o el modelo de Vida Independiente no eran suficientes, al igual que la Convención no es suficiente. Hay un $10 \%$ de cosas que quedan fuera y son un $10 \%$ tan sencillo como si queremos vivir, si merece vale la pena que nazcamos, si hay que abortarnos, si es lógico dejarnos morir... esos pequeños detalles sin importancia. [...]

Javier intenta inscribir la diferencia en un horizonte de significados compartidos más amplio: pasar de la diferencia que estigmatiza y separa a la diversidad humana de la que todos formamos parte. Entiende como superado el modelo social, incluso eleva la discusión a aspectos muchas veces soslayados, como la muerte asistida, el aborto por motivos de discapacidad del feto, y otros que inscriben la demanda de igualdad y dignidad en un contexto generalmente silenciado. Volviendo al punto que me interesaba de la entrevista, insisto en el término que Javier propone:

- Tú hablas del término diversidad funcional y después hablas del término de diversidad visual, de diversidad motriz-.

- [...] hablas de diversidad funcional, y dices "bueno, hay varios tipos de diversidad funcional: física, diversidad funcional visual...” ¿Qué ocurre? Que la gente, cuando tú empiezas a hablar en vez de escribir, dice, eso está muy largo, y entonces el "funcional" se cae. Haces uso del lenguaje natural, y dices "bueno vamos a dejarlo en diversidad física" pero no por ninguna reflexión, sino porque la gente lo usa de esa manera. Dejamos diversidad funcional para que englobe toda la funcionalidad y para cada especificidad, nos ahorramos el "funcional" y dejamos diversidad física, diversidad auditiva...que me parece más bonito, porque es más concreto.-

Javier percibe correctamente el sentido de mis repreguntas:

Ahora, mi pregunta apunta a lo siguiente: ¿cómo le llamarías a una persona con diversidad...cómo por ejemplo yo?

El término correcto formalmente es una "persona discriminada por su diversidad funcional” PDDF. Yo desconozco si tú sufres discriminación por alguna diversidad funcional tuya, creo que no... El mejor término es largo: "persona discriminada por diversidad funcional", "hombres y mujeres discriminados...", 
esto en la economía del lenguaje no funciona. O sea, la clave está en la discriminación, pero no se promueve lo suficiente, de hecho el acrónimo era PDF, y yo llevo dándole vueltas y cambiamos por PDDF... lo que pasa es que cuando hablas de diversidad funcional, la gente no sabe si está o no está, pero el que se siente dentro sí sabe que está.

En estos párrafos Javier abre una perspectiva a la que regresaré, pero me interesa cerrar mi cuestionamiento a las referencias "médicas" e incluso "patológicas" con las que el término diversidad funcional sigue cargando:

Es claro, pero me quedo pensando en la forma: "diversidad funcional motora" por ejemplo, entonces ¿a mí me dirías...qué? ¿normal? ¿diversidad funcional normal? Si es así, el problema del término vuelve a ser el apellido, no el nombre.

Claro, ese es el punto [...], es que hay que convencer a la sociedad que esto es cosa de todos.

Entonces uno de los esfuerzos del término es generalizar, que todo mundo se sienta parte de... a la vez que pones la barrera de discriminación. No queremos discriminar al resto, todos tenemos diversidad funcional, ahora algunos estamos discriminados y nos acercamos más al término de referencia..., pero la pretensión teórica es que todo mundo se sienta identificado, que haya un doble juego de barrera y globalidad, es un poco complicado porque es difícil de explicar.

Javier cruza aquí la línea constrictora de la lógica parmenídea y claramente parado en la filosofía de Heráclito y la lógica borrosa, afirma en sus propias palabras: la coincidencia de los opuestos, la permanencia en el cambio, la imposibilidad de dar a cualquier cosa un nombre unívoco y que "lo divergente siempre converge".

- Estás adentro y estás afuera.-

- Exactamente. Intentamos englobar a todo mundo y luego al revés, diferenciar: "pues no, tú no estás discriminado". Y nosotros trabajamos para que no estés discriminado mañana, porque te va a tocar, porque ya tuviste diversidad funcional cuando eras niño ya estuviste discriminado porque no llegabas al ascensor... y ese tipo de cosas.

Reconozco que es un poco sutil todo esto, en un mundo en que todo tiene que ser blanco o negro. Y esto de intentar globalizar o de incorporar a toda la sociedad a la par y a la vez hacerla consciente de que hay personas que son discriminadas por algo que todo mundo quiere... es un lenguaje complicado. Pero a nosotros no nos crea dificultad, eso es fácil, la clave está en la discriminación, lo que queremos desaparecer es la discriminación, no en la diversidad funcional, porque esa es humana, y esa sí que es humana. Entonces la mayor parte de la crítica es que "allí estamos todos"... yo digo "correcto" lo gracioso es que incluye a todo mundo, pero discapacidad también incluía a todo mundo. 
- Sí, según como lo vieras, sí. -

- Claro, pero nadie se sentía incluido. Cambias el término, pones diversidad funcional y dicen "pero eso me toca a mí”, ¡claro!, le digo: también te tocaba discapacidad pero nunca lo dijiste, porque como era negativo nunca lo incorporaste, ahora te pongo un término neutro y dices “¡coño! ése soy yo”. ¡Perfecto! eso es lo que yo quería.-

Javier enfatiza que el término correcto sería demasiado largo: "persona discriminada por su diversidad funcional", pero también reconoce que por economía del lenguaje este término pasa a "persona con diversidad funcional física" (por ejemplo), y luego a "diversidad física".

Mi interpretación es diferente: el concepto de discapacidad subyace debajo del de "diversidad funcional", permanece connotado, y mucho más aún cuando se lo asocia a una patología para especificar de qué "tipo" de diversidad se habla. Que el criterio de la discriminación que Javier, y concuerdo con él, considera el más significativo sea justamente el que desaparece, el que se torna mudo, da cuenta de algo que también está acallado en lo social: la situación de la persona no depende de su discapacidad, sino de la manera en que la sociedad considera -por acción u omisión, de forma explícita o implícita- que debe ser tratada.

Un aporte central de la discusión que propone Javier es el carácter dual que el término diversidad funcional pretende imponer y cuyas palabras centrales rescato:

"Lo que pasa es que cuando hablas de diversidad funcional, la gente no sabe si está o no está, pero el que se siente dentro sí sabe que está."

"Entonces uno de los esfuerzos del término es generalizar, que todo mundo se sienta parte de... a la vez que pones la barrera de discriminación. [...] la pretensión teórica es que todo mundo se sienta identificado, que haya un doble juego de barrera y globalidad, es un poco complicado porque es difícil de explicar."

"Reconozco que es un poco sutil todo esto, en un mundo en que todo tiene que ser blanco o negro. Y esto de intentar globalizar o de incorporar a toda la sociedad a la par y a la vez hacerla consciente de que hay personas que son discriminadas por algo que todo mundo quiere (la diversidad)... es un lenguaje complicado."

Un término con la pretensión de marcar una categoría universal de igualdad y una situación peculiar de diferencia. Un concepto que incluye y excluye a la vez. Que engulle y expulsa. Un "término neutro". ¿Una definición que no define?

Diversidad funcional hace referencia, según el propio Javier explicaba en una conferencia, a la misma función realizada de diferente manera: trasladarse en silla de ruedas en lugar de hacerlo caminando, leer por tacto en lugar que 
visualmente. Pero eso supone en primer lugar la existencia de esos apoyos o conocimientos. ¿Cuántas personas de nuestro contexto latinoamericano no cuentan con ellos? ¿sigue siendo diversidad funcional? ¿o es un concepto pensado para la realidad socioeconómica del primer mundo?

Tal como expresé en la entrevista, me parece un intento valioso por deconstruir el término "discapacidad" como referencia a una situación que excede lo individual. Diría también que el esfuerzo es una punta de lanza: diversidad funcional no es un concepto sociológicamente pertinente porque no da cuenta de las relaciones sociales en juego, sino de una condición humana.

Diversidad funcional pretende nombrar una condición inherente al ser humano y que experimentamos en las diferentes etapas de nuestras vidas: en este mismo momento si me quitara las gafas no podría estar escribiendo, o debería ajustar el tamaño de las letras en mi pantalla y mi teclado. Pero falta nombrarla, intento que realizó Javier, asociada a la vez al modo en que es socialmente significada: como una condición que justifica o legitima un trato discriminatorio o segregante.

Sin embargo, aun cuando asumimos -junto con Javier- que la mayor riqueza de la naturaleza y la humanidad es su diversidad, debemos aceptar -para un análisis sociológico desprendido de todo romanticismo- las evidencias del modo en que funcionan las sociedades: no se valora igual la producción "artesanal" de una comunidad Mapuche o Tzotzil que una producción "artística" de pintura flamenca; los migrantes no tienen estatus de ciudadanos en igualdad de condiciones, aunque su diversidad enriquezca a la sociedad. Se han legitimado prácticas y discursos para decir qué diversidad "es mejor" que otra, qué aspecto del sujeto lo deja fuera del conjunto o en un estatus inferior. Y el gran aporte de la irrupción del tema en la sociología es cuestionar y deconstruir no solo la legitimidad y autoridad del discurso médico respecto a la discapacidad, sino de cualquier discurso que legitime jerarquizaciones siempre arbitrarias.

He aquí la segunda dificultad: encontrar un término que defina sociológicamente la cuestión y que ponga el énfasis - no en la condición del sujeto- sino en las interrelaciones sociales. Soy consciente de que "otro" define una posición, en un campo de posiciones y de relaciones entre posiciones, que no es ocupada solamente por personas con discapacidad: somos sociedades productoras de "otros". No obstante cuando la posición de otro le es asignada a una persona con discapacidad intelectual, esa posición adquiere una calidad radical (absoluta, permanente e irreversible) de otredad. 


\section{Filmografía}

Slaboshpitsky M., 2014, La Tribu/PLEMYA, origen: Ucrania-Países Bajos.

\section{Bibliografía}

Abberley, P. 2008. "El concepto de opresión y el desarrollo de una teoría social de la discapacidad”, en: Barton L. (comp.), Superar las barreras de la discapacidad, Madrid: Morata.

Adams, M./Blumenfeld, W. J./Castañeda C./Hackman H./Peters M./Zúñiga X. 2000. Readings for Diversity and Social Justice: An Anthology on Racism, Antisemitism, Sexism, Heterosexism, Ableism, and Classism, New York: Routledge.

Beck, U. et al. 2003. La individualización, Barcelona: Paidós.

Brogna, P. 2009. "La vigencia del pasado en las estructuras sociales vigentes", en: Brogna (comp.), Visiones y revisiones de la discapacidad, México: Fondo de Cultura Económica: pp. 157-187.

Brogna, P. 2012. "Condición de adulto con discapacidad intelectual posición social y simbólica de otro", Tesis doctoral, México, FCPyS-UNAM, http://132.248.9.195/ptd2013/abril/0693202/Index.html [19-04-2019].

Bourdieu, P. 2007. Razones prácticas, 4ª ed., Barcelona: Anagrama.

Castel, R. 1997. Las metamorfosis de la cuestión social: una crónica del salariado, México: Paidós.

Deleuze, G. 2005. Lógica del sentido, México: Paidós.

Foucault, M. 1992. Microfísica del poder, $3^{\text {a }}$ ed., Madrid: La Piqueta.

Goffman, E. 2004. Internados, Buenos Aires: Amorrortu.

Lane, Harlan. 1992. The mask of benevolence: disabling the deaf community, New York: Knopf.

Mbembe, A. 2016. Crítica de la razón negra, Buenos Aires: Futuro Anterior Ediciones.

Santos, S./Bubniak/Velloso, B. 2018. "Representações sociais e educação ambiental: surdos no filme A gangue", en: Rev. Eletrônica Mestr. Educ. Ambient, Rio Grande, 35 (1): 76-91, http://repositorio.furg.br/bitstream/ handle/1/7805/7367-22692-1-PB.pdf? sequence=1 [19-04-2019].

Usandivaras, R. 1982. Grupo, pensamiento y mito, Buenos Aires: EUDEBA. van Dijk, T. Comp. 2000. “El estudio del discurso", en: Teun A. van Dijk (comp.), El discurso como estructura y proceso, Barcelona: Gedisa. 
Zabala, L. 2010a. "El análisis cinematográfico y su diversidad metodológica", en: Revista Casa del tiempo", http://www.uam.mx/difusion/casadeltiempo/30_ iv_abr_2010/casa_del_tiempo_eIV_num30_65_69.pdf [19-04-2019].

Zabala, L. 2010b. Teoría y práctica del análisis cinematográfico: la seducción luminosa, México: Trillas: 107-123.

\section{Fuentes hemerográficas}

Chang K. 2015. "A conversation with Yana Novikova \& Miroslav Slaboshpitsky", en: http://Anthemmagazine.Com/A-Conversation-With-Yana-NovikovaMiroslav-Slaboshpitsky/ [19-04-2019].

Zas Marcos, M. 2016. “'La Tribu', denuncia y violencia en lenguaje de signos”, en: https://www.eldiario.es/cultura/cine/Tribu-denuncia-mafia-sordera-lenguajesordomudos_0_513049090.html [19-04-2019]. 
V. Inclusión entre othering y normalización 

Susanne Hartwig

Universität Passau

\title{
Cuestión de perspectiva: la diversidad funcional en el cine contemporáneo
}

\author{
No puedo participar en un partido de fútbol en silla \\ de ruedas sin modificar de manera decisiva lo que se \\ entiende por 'jugar al fútbol'. (Kastl 2017: 271)1
}

\begin{abstract}
Although people with cognitive impairment participate increasingly in contemporary cinema, their involvement in the production and creation process remains superficial. Traditional standards, expectations and viewing habits subsist. This chapter examines two different forms of inclusion in two films: the very successful movie Campeones (Spain 2018; directed by Javier Fesser) and the documentary Gabor (Argentina/Spain 2013; directed by Sebastián Alfie). The protagonists of both films are people with disabilities. Inclusion, thus, is realized not only by choosing the topic 'disability', but also by integrating the point of view of people concerned. However, the function of disability in the film structure and the narration varies considerably in both films. While Campeones approaches to inclusion from the perspective of 'normalcy', Gabor examines 'normalcy' under the aspect of inclusion. The analysis of both films uses three key aspects of disability - corporeality/restriction, stereotype/stigma and social reaction/ambivalence - to distinguish real inclusion from phantom inclusion or illusory inclusion. Last but not least, the analysis raises the question about the possibilities and restrictions of cinematographic inclusion.
\end{abstract}

Keywords: corporeality, stigma, ambivalence, phantom inclusion, illusory inclusion

\section{Introducción}

La presencia de actores con diversidad funcional en el cine contemporáneo va aumentando. La obra ganadora de la Berlinale del 2018, Touch me not (dirección: Adina Pintilie), hasta plantea un tema tabú como la sexualidad entre personas con disfunciones corporales y psíquicas. En muchas ocasiones, sin embargo, la inclusión cinematográfica se mantiene en la superficie: se habla sobre y con personas con diversidad funcional utilizando las perspectivas visuales y

1 "Ich kann nicht mit einem Rollstuhl an einem Fußballspiel teilnehmen, ohne entscheidend das Verständnis dessen zu verändern, was Fußballspielen bedeutet” (Kastl 2017: 271; traducción S.H.). 
conceptuales desde la normalidad. Las historias narradas y los contextos elegidos finalmente no perturban las normas, expectativas y convicciones conocidas y no hacen frente a la ambivalencia estrechamente ligada a la cooperación y la comunicación complejas y hasta dilemáticas entre personas con y sin diversidad funcional. Reprimiendo, negando o eludiéndolas, las películas no brindan nuevas ideas sobre una inclusión más compleja. En pocas ocasiones, sin embargo, la persona con diversidad funcional influencia la narración cinematográfica de tal manera que esta abandona los caminos trillados de la normalidad.

A través del análisis de dos películas recientes, la película ficcional Campeones (España 2018; dirección: Javier Fesser) y el documental Gabor (Argentina/ España 2013; dirección: Sebastián Alfie), la presente contribución explorará dos formas de inclusión de personas con diversidad funcional en el cine. Ambas películas trabajan con protagonistas con y sin diversidad funcional volviéndolas partes integrales de la historia. No solo abordan el tema de la diversidad funcional sino que dejan que las personas con diversidad funcional influencien la estructura de la obra. Sin embargo, la función que atribuyen a la diversidad funcional en el mecanismo de la historia narrada es muy distinta en cada ejemplo. Mientras que Campeones se acerca a la inclusión bajo la perspectiva de la normalización de la diferencia, Gabor enfrenta la normalidad bajo la perspectiva de la inclusión. Se plantea la cuestión acerca de lo que se aprende sobre la inclusión a través de estas dos películas.

\section{Aspectos de la inclusión}

Partimos de una definición de la diversidad funcional como la combinación de una afección corporal, cognitiva o psíquica que altera gravemente la participación en la vida colectiva, con una estigmatización social sensible, pero no abiertamente admitida. ${ }^{2}$ De esta definición se desprenden tres aspectos importantes para el análisis del tipo de inclusión realizada en una película:

1) Corporalidad, o sea, limitaciones. Los límites del cuerpo humano y de la mente humana condicionan las prácticas sociales: el modo de pensar, de percibir y de sentir de los seres humanos (no solo en el caso de la diversidad funcional). De hecho, cada contexto social y cada práctica social implican expectativas y exigencias complejas para los participantes, estrechamente relacionadas a funciones

2 Hacer hincapié en los límites corporales (la disfunción, el impairment) no excluye la perspectiva que considera la diversidad funcional una construcción social, sino que admite que la diversidad funcional implica también una parte corporal que condiciona la interacción social. 
corporales o cognitivas consideradas normales (véase Kastl 2015: 58 y 282). ${ }^{3}$ En algunos contextos sociales, la plena participación de personas con diversidad funcional es realizable solo con modificaciones significativas del contexto con las que este corre el peligro de perder su especificidad o incluso su razón de ser. En estas ocasiones, los contextos probablemente no se prestan a la inclusión y una persona, por sus condiciones corporales o mentales, puede ser virtualmente incapaz de participar. ${ }^{4}$ Entonces, el primer criterio para diferenciar las perspectivas de una película respecto a la inclusión es su manera de manejar las limitaciones corporales de la diversidad funcional.

2) Estereotipos, o sea, estigma. La diversidad funcional es una desviación de los estándares altamente valorados socialmente, tales como la capacidad productiva, el rendimiento económico, la salud, la belleza, la inteligencia, etc. (véase Cloerkes 2014: 123). En consecuencia, va pareja con muchos estereotipos con connotación negativa, toque compasivo o simbolismo paternalista. Estos estereotipos sociales sirven de telón de fondo para narrativas como el "overcoming narrative" (que afirma que hay que combatir la diversidad funcional) o el "compensation narrative" (que afirma que la diversidad funcional es algo negativo pero que por lo menos sirve para algo; véase Hartwig 2018: 9). ${ }^{5}$ La diversidad funcional aparece también con frecuencia como símbolo de un defecto interior. ${ }^{6}$ Los estereotipos estigmatizan a las personas con diversidad funcional atribuyéndoles una categoría social inferior (véase la definición del estigma en Goffman 1991).

Whatever the physically impaired person may think of himself, he is attributed a negative identity by society, and much of his social life is a struggle against this imposed image. It is for this reason that we can say that stigmatization is less a by-product of disability than its substance. The greatest impediment to a person's taking full part in his society are not his physical flaws, but rather the tissue of myths, fears, and misunderstandings that society attaches to them. (Murphy 2001: 113)

3 Kastl habla de una suerte de "acoplamiento" entre cuerpo y práctica social (2017: 80-81). No se refiere solo a las exigencias sociales sino también a los conceptos del cuerpo normal y del comportamiento normal que tienen los actuantes sociales (Kastl 2017: 105).

4 Este hecho no debe impedir que se distingan bien las limitaciones corporales de las limitaciones creadas por la práctica social porque esta determina hasta qué punto las limitaciones corporales tienen un efecto negativo en la vida social (véase, por ejemplo, Felkendorff 2003).

5 Véanse Murray 2008: xvi, Grue 2015: 109-110, Osteen 2008.

6 Sobre el simbolismo de la discapacidad véanse, entre otros, Mitchell/Snyder (2000: 58-61) y Barker/Murray (2018: 1-2). 
El manejo del estigma puede considerarse un segundo criterio para diferenciar los tipos de inclusión que una historia implica.

3) Reacciones sociales, o sea, ambivalencia. Las situaciones sociales en las que se encuentran personas con o sin diversidad funcional suelen estar marcadas por una tensión básica que resulta de la anomalía respecto a las normas y expectativas sociales (véase la definición en Kastl 2017: 107). ${ }^{7}$

Neither knows what the other expects. The tension created by misunderstood and unexpressed expectations may increase the tendency for persons without disabilities to ostracize those with disabilities and for those with disabilities to avoid contact with persons who do not have disabilities. (Westerholm et al. 2006: 1504)

Desde un punto de vista sociológico, la situación social en la que se encuentran personas con y sin diversidad funcional es subdeterminada, es decir, no existen normas inequívocas de comportamiento, ${ }^{8}$ lo que causa un malestar en todos:

Even if the able-bodied person is making a conscious attempt to pay deference to the disabled party, he must struggle against the underlying ambiguity of the encounter, the lack of clear cultural guidelines on how to behave, and perhaps his own sense of revulsion. (Murphy 2001: 121)

Este malestar se ve agravado por una ambivalencia aprendida durante la socialización y debida al hecho de que una persona sin diversidad funcional puede tener dos reacciones contrarias al enfrentarse con la diversidad funcional: por un lado, una reacción originaria (en la terminología del sociólogo alemán Günther Cloerkes, véase Cloerkes 2014) que se basa en lo que ha aprendido desde muy temprana edad sobre las sanciones contra todo tipo de desviaciones (y al mismo tiempo sobre las expectativas respecto al cuerpo, al movimiento y al comportamiento social); por otro lado, una reacción 'oficialmente deseada' que, por la norma ética, exige que los actores sociales acepten la desviación que constituye la discapacidad y no expresen su rechazo (véanse Cloerkes 2014: 127; Kastl 2015: 266). El choque entre estas dos reacciones puede dotar el encuentro entre personas con y sin diversidad funcional de una ambivalencia que suele desembocar en una 'reacción corregida' (überformte Reaktion), o sea, una reacción forzada, inhibida y constreñida (véase Cloerkes 2014: 126). Esta reacción

7 Esta afirmación no vale, por supuesto, para las personas habituadas a la diversidad funcional.

8 El cuerpo (o el comportamiento) divergente hacen difícil una 'definición de la situación social' que puede servir de base para el intercambio social (Cloerkes 2014: 131). Las categorías normales no funcionan, el estatus de la persona con diversidad funcional dentro de la estructura social es incierto (Kastl 2015: 268). 
oculta los sentimientos no deseados y, tarde o temprano, tiene como resultado que las personas con y sin diversidad funcional eviten encontrarse. Puesto que la discapacidad está fundamentalmente marcada por esta ambivalencia, el tercer criterio para distinguir diferentes tipos de inclusión es su manera de enfrentarla. ${ }^{9}$ Si se permite, por ejemplo, permitir a las personas sin diversidad funcional mirar detenidamente una anomalía corporal, la calidad de la interacción entre personas con y sin discapacidad puede mejorar, porque se reduce la inseguridad, el estrés y el malestar para ambas (Cloerkes 2014: 136). Pues si es posible sentir abiertamente las reacciones originarias, un 'comportamiento explorativo' es capaz de transformarlas (ibíd.).

Estos tres aspectos de la diversidad funcional permiten describir distintos tipos de inclusión, por ejemplo, en el cine. Si una película aborda las limitaciones corporales, exhibe los estereotipos como tales, o los anula o si trata la ambivalencia que surge en los encuentros con personas con diversidad funcional sin disiparla (ni exagerarla tampoco), es capaz de crear complejas situaciones inclusivas y contribuir al empowerment de las personas con y sin diversidad funcional. ${ }^{10}$

Si la inclusión permanece superficial, se crea un mundo paralelo donde la diversidad funcional está incondicionalmente aceptada, eso sí, pero de manera poco realista (lo que podríamos llamar una illusory inclusion siguiendo el concepto de "Scheininklusion" de Kastl 2015), o se asimila a las personas con diversidad funcional a la normalidad (lo que sería una phantom inclusión por utilizar un calco del término phantom normalcy de Goffman). La illusory inclusion se suele realizar en forma de 'rituales inclusivos' ("Inklusionsrituale", véase Kastl 2015: 271) que simulan una armonía irreal sin ocasionar un verdadero paso de un estado anterior a uno nuevo en la vida social real (Kastl 2015: 285). Solo presenta los aspectos positivos de una inclusión deseada excluyendo cualquier ambivalencia u otro tipo de complejidad en las interacciones sociales. La phantom normalcy es una tácita adaptación de la persona con diversidad funcional a las normas sociales en vigor, que no pone a prueba a las personas sin diversidad funcional.

9 Ambivalencia significa que las personas que intentan averiguar lo que significan las personas y las relaciones sociales para su identidad y sus posibilidades de actuar oscilan entre sentimientos, pensamientos e intenciones contradictorios (Lüscher 2012: 20). Veáse también la definición de Korczak (2012: 7).

10 Bajo empowerment entendemos estrategias que aumentan la libertad en la organización de la vida social, así como la autodeterminación y la autonomía de las personas marginalizadas (Schönhuth 2011: 57). 
The stigmatized individual is asked to act so as to imply neither that his burden is heavy nor that bearing it has made him different from us; at die same time he must keep himself at that remove from us which ensures our painlessly being able to confirm this belief about him. A phantom acceptance is thus allowed to provide the base for a phantom normalcy. [...] in many cases the degree to which normals accept the stigmatized individual can be maximized by his acting with full spontaneity and naturalness as if the conditional acceptance of him, which he is careful not to overreach, is full acceptance. (Goffman 1991: 122-123)

Una phantom inclusion funciona de manera análoga: pretende la normalidad de la diversidad funcional reduciendo los problemas entre personas con y sin diversidad funcional a una cuestión de buena voluntad. ${ }^{11}$ La perspectiva y la organización de la vida social en vigor quedan intactas.

\section{Ejemplos del cine}

Campeones, ${ }^{12}$ el mejor estreno español del año 2018, incluye a diez actores con diversidad funcional cognitiva y sin ninguna experiencia profesional. ${ }^{13}$ La resonancia positiva del público es tan asombrosa que hasta un crítico afirma que "Campeones es nuestra Intocable" (Luisjo 2018), con referencia a la exitosa película francesa del año 2012 sobre la amistad de un delincuente de una barrio social conflictivo y un rico aristócrata tetrapléjico. El documental Gabor, ${ }^{14}$ en cambio, pasa casi desapercibido por el gran público a pesar de ganar varios premios (entre ellos el premio Gaudí de España). Es una película sobre la producción de un videoclip de promoción que integra a un director de fotografía ciego. En ambas películas, las personas con diversidad funcional tienen voz y visibilidad y se establece un intenso contacto entre personas con y sin diversidad funcional con un objetivo común: ganar un campeonato o, respectivamente realizar un videoclip, lo que crea una interdependencia propicia a una percepción inclusiva. Aunque en el primer caso hablamos de una película de ficción y en el

11 Kastl escribe sobre el 'discurso inclusionista' que muestra afinidades con la prohibición religiosa de imágenes porque se lanza un tabú sobre la representación icónica de la realidad del daño (véase Kastl 2017: 342).

12 Dirección y montaje: Javier Fesser; guión: David Marqués, Javier Fesser; fotografía: Chechu Graf.

13 El director fue asesorado por asociaciones de personas con diversidad funcional. Algunas personas con diversidad funcional trabajan también en tareas de producción o catering (Europa Press 2018).

14 Dirección: Sebastián Alfie; guion: Sebastián Alfie, Albert Soler, Pedro Loeb; fotografía: Ángel Amorós; montaje: Javier Lafaille. 
segundo caso, de un documental, ambos textos son comparables desde el punto de vista del concepto de la inclusión que ofrecen, según los tres aspectos que destacamos en la parte anterior.

\subsection{Campeones}

La "comedia muy seria" (solapa del dvd) Campeones narra la historia de Marco, que se transforma de una persona inmadura en adulto capaz de ser padre de familia. Marco es el segundo entrenador de baloncesto de un equipo que juega en la segunda división. Por orden de una jueza (y como alternativa a la cárcel) tiene que entrenar a un equipo de personas con diversidad funcional cognitiva. Acepta a regañadientes, pero poco a poco se compromete con su nuevo equipo y encuentra soluciones a cualquier obstáculo que se presente. Aprende a explicar los movimientos y la táctica del baloncesto de forma adaptada a sus alumnos, a pensar el espíritu de equipo desde la diversidad y el baloncesto, desde el respeto hacia los adversarios y la alegría de jugar. Cuando su equipo pierde la final del campeonato, celebra esta ocasión como una victoria, junto con sus subcampeones. Al final vuelve a su puesto de entrenador de baloncesto profesional.

La historia funciona sobre un esquema conocido que se centra en la utilidad de la persona con diversidad funcional para su entorno al que ayuda a desarrollar sus virtudes sociales. La particularidad de Campeones es que utiliza este esquema con cierto distanciamiento irónico causado por un protagonista que roza continuamente lo caricaturesco y un ambiente a veces surrealista. Casi todos los personajes son excéntricos y tienen sus virtudes así como sus defectos. ${ }^{15}$ Los momentos emocionales y conmovedores son instantáneamente neutralizados por imágenes o comentarios banales; los moldes conocidos se citan a menudo sin ejecutarse correctamente. ${ }^{16}$ En este sentido se orienta también el momento más dramático de la película, los últimos segundos de la final: el último tiro a la canasta se representa primero en slow motion y desde la perspectiva de la pelota para aumentar el suspense y luego desde la perspectiva de los espectadores, en la que la pelota erra el blanco. A modo de parodia de los estereotipos de las películas hollywoodienses de superación en el deporte, el equipo se muestra muy

15 Hay pocos personajes unidimensionales, que son secundarios y muy estereotipados: el 'amigo traidor' Iván o la 'esposa ideal' Sonia.

16 Por ejemplo, la escena de la ducha en la que Juanma se cura de su trauma al agua: suena música épica y los protagonistas se abrazan (lo que sería un momento cumbre en la lógica hollywoodense), pero son interrumpidos por la pregunta banal de un jugador sobre cómo van a ir a Cuenca (57:45). 
satisfecho con ser subcampeón (1:45:47). En cuanto a la inclusión, Campeones juega sobre una inversión. No son los jugadores con diversidad funcional los que deben ser incluidos en el mundo de los 'normales', sino el 'normal' que debe internarse en su mundo. El único personaje melodramático, Ramón, alude varias veces a esta lógica del 'mundo al revés. ${ }^{17}$

Los efectos cómicos resultan mayoritariamente de la comparación entre lo 'normal' y lo 'raro' en las formas de cooperación y de comunicación sociales. La primera parte de la película se centra en la anormalidad del equipo y de su manera particular de jugar al baloncesto. Ya la primera impresión de los jugadores (17:36) constituye una versión distorsionada de las típicas fotos de equipos de deporte. El efecto cómico de esta imagen se prepara ya en la escena anterior cuando un diálogo rápido resume la diferencia entre un entrenamiento normal y uno con 'discapacitados':

Julio:“Qué honor que un profesional como tú esté interesado en trabajar con un equipo como el nuestro."

Marco:"Interesado no sería la palabra."

Julio:"Ni equipo tampoco." (13:41-13:48)

El comportamiento inesperado y aparentemente sin lógica de los jugadores recuerda muchas veces el dadaísmo, una forma de resistencia a lo racional y a la normalidad. Este efecto se ve subrayado por el lugar en el que se juega: en las paredes del pabellón hay escritas palabras o frases de animación (que cambian durante la película) que se parecen a comentarios de la acción, a veces atinados, otras veces irónicos o disparatados. En la segunda parte de la película -que comienza con los partidos fuera de casa- el efecto cómico proviene sobre todo de las infracciones a las normas sociales, celebradas como irreverencia carnavalesca. Se acentúa con la aparición espectacular ${ }^{18}$ del personaje Collantes, una jugadora con síndrome de Down y una autoestima inquebrantable. Esta permite al público volver a la irresponsabilidad sin consecuencias graves de la infancia.

17 Román abandona a Marco (32:58); luego admite que Marco "[e]stá aprendiendo" (1:18:31), para constatar -en una mezcla de reconocimiento y resignación- que "[l]a discapacidad [Marco] la va a tener siempre, pero nosotros le estamos enseñando a manejarla" (1:18:34). En la escena final afirma que el equipo no ha tenido tiempo de "encarrillar[lo] del todo" (1:53:32) a Marco, pero que están contentos con el resultado.

18 Se escucha música electrónica y los gritos alentadores en coro de los demás jugadores. Collantes viste como una hippie, lleva accesorios fuera de lugar, soluciona sus combates singulares con una patada en los genitales del adversario y tiene como preocupación mayor que no la tuteen. 
En ambas partes de la película, los efectos cómicos, surrealistas o dadaístas rompen las reglas sociales, pero sin cambiarlas; el único al que los jugadores con diversidad funcional consiguen transformar es a Marco. Desde el principio se ve un parecido nítido entre este y las personas con diversidad funcional. ${ }^{19}$ A través de este paralelismo y algunas afirmaciones más,${ }^{20}$ la película se acerca a una fraternización del tipo 'todos somos anormales, luego iguales'. Pero Marco se cura de sus anormalidades, no solo de su pavor a los ascensores, sino también de su inmadurez. Al final vuelve a vivir en la sociedad de los normales. Asume su papel paternal, mientras que los jugadores se mantienen en una eterna niñez, lo que recuerda un estereotipo paternalista muy expandido sobre la diversidad funcional cognitiva.

Puesto que las escenas cómicas no tienen un gran contrapeso en escenas serias, las infracciones a las normas de la sociedad parecen caprichos simpáticos. Las limitaciones cognitivas no se sienten dolorosamente porque la selección de los planos y los cortes rápidos las camuflan o las utilizan para efectos cómicos inofensivos. ${ }^{21}$ Las historias detrás de las diversidades funcionales no se cuentan en detalle;22 únicamente el melodrama de Ramón se esboza. La diversidad funcional se reduce a una diversidad cualquiera.

El baloncesto, punto de referencia constante de la película, establece una perspectiva desde la normalidad. El juego no permite una expresión específica a la gente con diversidad funcional cognitiva ni desarrolla su potencial genuino. Al contrario, en Campeones, el deporte constituye una medida para resaltar el déficit (intelectual y corporal) de las personas con diversidad como fuente cómica continua, sobre todo en la primera parte de la película. La práctica social 'baloncesto' supone reglas y exigencias específicas como premisas insoslayables que

19 El comportamiento de Marco también es irreverente y cómico, por ejemplo, en el juicio; tiene sus neurosis y siente como estigma corporal su baja estatura, que no le permite ser jugador de baloncesto profesional. Sonia tilda a su marido de Peter Pan, confiriéndole el carácter de un niño.

20 “Y ¿quién es normal Marco? ¿Tú y yo somos normales?” pregunta Julio (22:33); “Somos normales. Es que tenemos distintas capacidades", afirma Fabián (1:06:48).

21 El cine controla la mirada del espectador; la selección de imágenes y de palabras así como los cortes rápidos mitigan la excentricidad de las limitaciones corporales de los protagonistas (por ejemplo, de los que no saben articularse bien). Además, no se deja el tiempo suficiente al espectador para mirar detenidamente a los jugadores.

22 En ningún momento de la película los personajes tienen discursos edificantes, ni melodramáticos ni moralizadores, ni siquiera cuando se explica sumariamente la manera de vivir con discapacidad (38:45). La vida de personas con diversidad funcional no se describe como un calvario. 
incluyen también la competición y cierta presión por obtener éxito. El tipo de baloncesto que las personas con diversidad funcional evocan, en cambio, está exento de jerarquías entre vencedores y vencidos, victorias y derrotas, o sea, se asemeja a un puro juego infantil. ${ }^{23}$ Además, el equipo participa en un campeonato nacional especial, reservado a personas con diversidad funcional cognitiva, o sea, un mundo deportivo aparte. Los papeles están distribuidos según los estereotipos conocidos: el saber técnico y el rendimiento en la competencia convienen a la persona normal, la sensibilidad y la solidaridad, a las personas fuera de la normalidad..$^{24} \mathrm{~A}$ través del baloncesto, la diversidad funcional se transforma en una metáfora (de lo emocional que triunfa sobre lo racional), otra de las tantas que existen ya en la literatura sobre personas con diversidad funcional (véanse Barker/Murray 2018: 2-3).

A través del deporte, la película simplifica la inclusión reduciéndola al problema de constituir un equipo, y la solución a este problema, a una cuestión de buena voluntad. ${ }^{25}$ La película retrata las limitaciones cognitivas de las personas con diversidad funcional solo de manera divertida. Por ejemplo, el tartamudeo una desviación del habla normal muy estigmatizada- aporta un toque surrealista al personaje; sobre todo el sobrino de la jueza musita a menudo palabras incomprensibles, pero la vinculación con la tía poderosa le confiere dignidad. La mayoría de los problemas que se solucionan 'en su momento' tienen su origen en el hipocondríaco Marín, como si los problemas relacionados con las limitaciones corporales fueran también sobre todo un asunto de la imaginación. Las duras condiciones bajo las que las personas afectadas tienen que vivir muchas veces en la realidad solo se intuyen a través del patrón de Benito que, sin embargo, se mantiene a nivel de caricatura sin las sutilezas de la estigmatización real que

23 Dentro de esta lógica, Marco vuelve finalmente al 'verdadero' deporte, y con una promoción a la primera división (1:51:34-1:51:46). Según sus palabras, va a dedicarse a la "gran oportunidad" y a "ganar[se] el pan" (1:53:00), o sea, algo más serio, más adulto que el campeonato de personas con diversidad funcional cognitiva.

24 Marco aporta su saber sobre el deporte, y las personas con diversidad sus conocimientos intuitivos sobre el espíritu deportivo (contra la sobrevaloración de la voluntad de ganar). Se reconoce aquí la idea del 'buen salvaje', mientras que Marco representa la civilización.

25 Por arte de magia (y sin que se vea ningún esfuerzo), la constitución del equipo soluciona también los problemas técnicos iniciales con el baloncesto, y los jugadores que "no saben ni pasarse la pelota el uno al otro" (22:23) se transforman en un famoso equipo de "subcampeones" en poco más de tres meses. 
padece la gente con diversidad funcional y que además será castigado al final por Marco y Sonia.

El contacto con personas fuera del mundo de la diversidad funcional se trata en la película con maniqueísmo: o el respeto falta absolutamente o no existe ni el menor problema con la aceptación. ${ }^{26}$ Las anormalidades a veces se potencian hasta la caricatura; algunas imágenes -al igual que el cartel de la película- aluden al freakshow, o sea, a la exposición de desviaciones corporales para satisfacer el sensacionalismo del público. Pero el freak de Campeones -el expulsado social con fuertes estigmas en el cuerpo- es más bien el friki, una persona extravagante pero inofensiva. En cambio, Campeones crea momentos de ambivalencia que confieren complejidad al retrato de la discapacidad, sobre todo en la primera parte de la película, donde se articulan explícitamente los prejuicios hacia los "subnormales" y se contrastan con lo políticamente correcto. Se permite al estigma salir a la luz utilizando sin tapujos los estereotipos negativos que expresan la condescendencia o el rechazo a las personas con diversidad funcional. La ambivalencia reside en el hecho de que no se brinda la 'reacción oficialmente deseada' en relación a la diversidad funcional y el espectador puede sentir une 'reacción primaria' rechazada. El espectador adopta la perspectiva de Marco, lo que le permite ver a las personas con diversidad funcional como a unos "raros" y así distender la interacción liberándola de las reacciones oprimidas. Algunos prejuicios se desmantelan in actu. ${ }^{27}$

La inclusión funciona a través de una meta común que integra a todos los personajes en un equipo y les brinda las soluciones para los problemas que surgen en el camino hacia la final del campeonato. Pero el deporte se desarrolla en un mundo paralelo, es decir, la inclusión deportiva se realiza sin integrar a las personas con diversidad porque el deporte de ellas constituye un subsistema; y como el deporte asimila a los jugadores a sus reglas, tampoco existe una diferenciación según las capacidades de los jugadores. Un equipo como el de Campeones constituye una comunidad imaginaria, que no aborda los problemas de la inclusión.

26 Cuando se atreven a pisar el mundo de los normales, como en el autobús público, fracasan rotundamente. La consecuencia - viaje en una furgoneta particular- les vale el epíteto de 'gamberros' (1:11:13) y nadie parece darse cuenta de que es una fuerte segregación social voluntaria.

27 Lo infundado que son los prejuicios no se explica sino que se hace experimentar al espectador, por ejemplo, cuando Marco lamenta la falta de coordinación absoluta de Benito (38:20) mientras se ve cómo este conduce una moto impecablemente; Paquito comenta que Benito nunca ha tenido un accidente, muy al contrario de Marco que tuvo que justificarse delante de una jueza por ser un peligro público al volante. 
Campeones no otorga una mirada compasiva a la discapacidad ni la idealiza, pero tampoco profundiza en los aspectos difíciles de su contingencia ${ }^{28}$ - ni en la ambivalencia en las relaciones entre personas con y sin diversidad funcional. Pero tampoco se acepta la diversidad funcional cognitiva como una identidad en pleno derecho. El diálogo entre Marco y Marín sobre el miedo a tener un hijo con diversidad funcional es particularmente revelador en este sentido; Marín (con diversidad funcional cognitiva) afirma que no le gustaría "tener un hijo como nosotros" (1:20:58) porque -y es esta explicación la que discrimina a las personas con diversidad funcional cognitiva- quiere que sus hijos "estén bien", y añade la frase "No soy tonto" (1:21:03). Entonces la diversidad funcional cognitiva ¿prohíbe el 'estar bien'? si Marín hubiera dicho que quiere que sus hijos tengan todas las posibilidades que les brinde la sociedad, su afirmación habría sido menos desdeñosa.

El tan alabado trabajo de sensibilización ${ }^{29}$ se limita a una exhortación al respeto hacia las personas con diversidad funcional. Este tipo de inclusión se define desde la normalidad y no desde una relativización de la perspectiva. Sintomáticamente, al final, los jugadores dan las gracias a Marco por haberlos convertido en un equipo, por haber sido un padre bueno (1:53:26) y por haberlos tratado como personas (1:53:57). No piden más, como, por ejemplo, entrar a su vez en el mundo de Marco. Por estas razones, Campeones es más bien un ejemplo de illusory inclusion.

\subsection{Gabor}

El documental Gabor cuenta la historia del director publicitario argentino Sebastián Alfie, que recibe el encargo por parte de la organización catalana Ojos del mundo de rodar: un corto promocional sobre personas ciegas en el interior de Bolivia que se dejan operar para recuperar la vista. A la búsqueda de una cámara especial, Alfie conoce al director de fotografía húngaro Gabor Bene que, debido a un glaucoma, lleva diez años sin poder ver. Alfie le invita a colaborar y la historia de su participación en el rodaje constituye el largometraje Gabor. ${ }^{30}$ La película

28 La discapacidad puede afectar a cualquier persona en cualquier momento de su vida, lo que se ve, por ejemplo, en el personaje de Ramón. Este moraliza solo a la gente que conduce borracha (porque un borracho causó su accidente), pero no reflexiona sobre la contingencia absoluta del accidente como tal.

29 Esta alabanza proviene, por ejemplo, de la asociación Plena Inclusión Madrid (Europa Press 2018).

30 La voz en off de Alfie comenta lo que se ve en la pantalla a modo de un diario, de manera que Gabor resulta una suerte de making of. 
se divide en dos partes: los primeros veinte minutos tratan la preparación del equipo para el rodaje y la relación entre Gabor y Alfie y abarcan cuatro semanas. ${ }^{31}$ Los cuarenta y cinco minutos siguientes muestran las circunstancias del rodaje entre la ciudad de la Paz y el municipio de El Alto en Bolivia durante dos semanas, más la proyección del clip en la Asociación Ojos del mundo en Barcelona y la repetición de una escena de la primera parte. ${ }^{32}$

El documental se basa en la tensión entre dos planteamientos opuestos: por un lado, incluir a una persona que no puede ver en un contexto donde la vista es indispensable y, por otro, desarrollar dos actitudes contradictorias frente a la ceguera: algo que hay que combatir (en el clip) y algo que hay que aceptar como modo de ser (en el largometraje). Ambos mensajes se sobreponen, puesto que muchas escenas y muchas personas aparecen en ambos contextos, el clip y el documental. ${ }^{33}$ Puesto que el clip tiene como objetivo animar a las personas invidentes a hacerse examinar en una clínica oftalmológica, exalta la vista como algo que hay que conservar, sobre todo a través de fotos hermosas traduciendo el gusto de ver. ${ }^{34}$ Los protagonistas (el panadero Víctor, el pintor Emilio, la campesina Eulogia y la cirujana Shirley Cuentas), el tema de las escenas intercaladas ${ }^{35}$ y la trama narrativa principal (examinación y operación de dos hombres, recuperación de la vista y vuelta al trabajo) están al servicio de este mensaje de salvar la vista. ${ }^{36}$ Un coro de alumnos que funciona como un epílogo al clip afirma que

31 En la primera escena, Alfie se presenta con una máscara de oxígeno en la cara, ya en Bolivia, recordando su primer contacto con Gabor y los preparativos del viaje.

32 Estas escenas paralelas muestran a Gabor en el barco con los ojos cerrados: la primera vez, habla de una reanimación de la memoria visual (17:53), la segunda vez, de lo bien que se lo pasó en el rodaje (1:06:18).

33 En el largometraje salen todos los protagonistas del clip, volviéndose secundarios, y el equipo de producción boliviano: foquista, productora y sonidista, y los nuevos protagonistas Gabor y Alfie.

34 En internet, se puede leer sobre la fundación Ojos del mundo que es "una organización sin ánimo de lucro que lucha contra la ceguera evitable, que es aquella que se puede prevenir o curar" (https://www.ullsdelmon.org/es/).

35 Unos planos que interrumpen la narración muestran el trabajo de la fundación: un quirófano, una consulta, la educación escolar y una exhortación a combatir la ceguera evitable (véase la versión final del clip con audiodescripción en https://www.youtube. com/watch?v=hi3w81GeVaQ; 19.09.2018). En Gabor se proyecta solo una primera versión del clip, sin letras.

36 Se proyectan imágenes del pintor con un implante de lente intraocular pintando una raya azul en una pared, así como imágenes del panadero, operado de cataratas, haciendo hogazas de pan. La trama más larga narra el viaje penoso de ida y vuelta de Eulalia, la cual ya no puede operarse. 
la ceguera es algo por evitar (1:02:22). El largometraje documental, en cambio, muestra lo que un no vidente es capaz de hacer. Alrededor de la historia del rodaje como núcleo narrativo, se descubren elementos típicos de un documental. ${ }^{37}$ Se brindan también algunos detalles de la enfermedad que causó la ceguera en Gabor. ${ }^{38}$

La película trabaja con constelaciones contradictorias, la mayor de las cuales es la de un director de fotografía ciego. El objeto que reúne a Alfie y a Gabor parece una ironía de la suerte: es una cámara de gran precisión que sirve para filmar objetos muy pequeños. La operación exitosa a la que asiste Gabor durante el rodaje es lo contrario de su propia experiencia (37:56). El enfoque sobre Gabor, ensimismado y melancólico, como si él y no el hombre operado fuera el verdadero protagonista de la operación, ${ }^{39}$ es un contrapunto al acontecimiento narrado: la recuperación de la vista. Algunas escenas parecen inapropiadas para un ciego, como la de Gabor rodando en el quirófano (42:02), en el travelling (49:52) o en el rail (49:45) que lo muestran moviéndose como si pudiera verlo todo. En una escena, Alfie y Gabor se 'miran' con perplejidad (ante un imprevisto en el último momento del rodaje; 58:40), y esta mirada físicamente imposible ilustra que el acto de mirarse es simbólico y no requiere necesariamente la vista.

Se equilibran momentos de frustración y momentos graciosos. Por ejemplo, se incluyen varias reacciones negativas al proyecto de Alfie de contratar a Gabor

37 Se cuenta la vida del protagonista en animación que utiliza unas líneas rojas y unos puntos rojos que simbolizan los viajes de Gabor sin una dirección dominante. También la presentación de los pacientes es en animación (diseños de ojos e imágenes médicas; el mapa de Bolivia; instrumentos oftalmológicos, 22:19-22:40). Hay también entrevistas con personas del entorno de Gabor, explicaciones profesionales y detalles del rodaje. Son entrevistados el asistente de cámara (21:00), el foquista (23:13), la jefa de producción (23:33); un actor de la película También la lluvia (25:07) y un paciente (25:34).

38 La ceguera de Gabor es representada como una ruptura (7:58): la pantalla blanca es invadida por regueros rojos que recuerdan unas lágrimas o gotas de sangre y que parecen un ojo filmado con una cámara con gran disolución, como al comienzo del documental (véase 7:13). En una escena, Gabor está sentado en un sillón (7:35) contando cómo se infectó el ojo. En otra escena, contesta las preguntas de algunos niños sobre su ceguera (1:01:08).

39 Se utiliza el plano contraplano: el estupor del pintor que vuelve a ver, por un lado, y, por otro, la cara taciturna de Gabor, la cabeza sustentada por el brazo (55:11). Al final, Gabor filma lo que el pintor afirma poder ver desde la ventana (56:29), como si la cámara fuera su prótesis. 
$(21: 00 ; 23: 13 ; 23: 40)$. El mismo director subraya varias veces lo arriesgado que considera el rodaje (por ejemplo, 14:48). Su relación con Gabor está llena de roces. Comenta también con su madre que en distintas ocasiones es patente que Gabor no asume su ceguera. ${ }^{40}$ En otros momentos, la ceguera se presta a bromas o a resaltar lo cómico de la situación. ${ }^{41}$ De todos modos, Gabor no admite ninguna interpretación mística de la ceguera (ni compasión ni admiración) y prefiere una actitud pragmática. ${ }^{42}$ Contesta a los niños que le preguntan cómo vive una persona que no ve con la palabra "Bien" y añade: "Come bien, duerme bien, ama bien" (1:01:00-1:01:04). Lo que le parece interesante es una persona con diversidad funcional superando obstáculos concretos, como por ejemplo una persona sin piernas jugando al fútbol (8:07).$^{43}$ Gabor es consciente de su limitación corporal ("Mi meta no es ver lo que no puedo ver"; 8:37), pero vive con ella sin dejar de dedicarse a su profesión. Muchas acciones pueden realizarse sin ver, cosa que se olvida a veces en una sociedad que valora altamente la vista. También respecto al panadero afirma: "Si puedo sobrevivir como fotógrafo, él puede sobrevivir como panadero, ¿no?” (52:33). El motor de este vivir con la limitación es su amor al cine que busca soluciones a los obstáculos. ${ }^{44}$ De hecho, la manera de trabajar de Gabor muestra cuánto pueden la imaginación y la memoria de 25

40 La madre de Alfie es profesora de orientación y movilidad de ciegos, es decir, tiene experiencia con el tipo de diversidad funcional que afecta a Gabor. Es la voz de la experta del mundo de la rehabilitación que se escucha tres veces en off.

41 Alfie y Gabor bromean sobre la tarifa de Gabor (14:21). En otra escena, hablan sobre si alguien le avisa cuando un mujer fea se le acerca (10:24). El equipo se ríe con Gabor cuando le pregunta cómo se imagina la cara de cada uno de ellos, y este pone etiquetas a cada miembro (59:22).

42 Afirma en una entrevista: "Si se es ciego, hay que construir un mundo propio. Punto. Intentar hacer lo que hacen los demás es fracasar. [...] Tampoco estoy haciendo una apología a la ceguera, es absurdo, pero si soy ciego es así. [...] La belleza sigue ahí, solo tienes que recibirla de otra manera" (Cruz Hoyos 2016).

43 El tema del fútbol se aborda otra vez en la película: en una escena al inicio de la película Alfie recuerda cómo jugaba al fútbol con personas invidentes cuando acompañaba a su madre en la infancia (11:52).

44 Alfie afirma que si alguien está enamorado del cine, "esta necesidad puede superar cualquier obstáculo" (mientras que el contraplano muestra a Gabor secándose los ojos; 14:06). Gabor es un especialista en sobrevivir en circunstancias precarias. Desde muy temprana edad se dedica a la fotografía y tiene una sólida formación teórica y práctica en cinematografía. Trabajó de director de fotografía de comerciales, documentales y telenovelas en distintos países. 
años de experiencia cuando existe la voluntad de realizar un proyecto anhelado con pasión. ${ }^{45}$ Gabor sabe indicar con precisión cómo hay que realizar la fotografía, basándose en descripciones verbales para imaginar el espacio. Pregunta por la luz e incluso la siente en su piel (10:00), posiciona la cámara, imagina los encuadres, soluciona problemas técnicos (el del travelling) y da sus opiniones sobre cómo debe hacerse la iluminación. Tiene algunas escenas completas realizadas ya en la mente. ${ }^{46}$

Según Alfie, el clip debe mostrar la diferencia entre ver y no ver, sin clichés (2:58), pero el largometraje amplía esta visión por considerar también a la persona que ve o no ve. De la pregunta sobre si es posible trabajar con un ciego se pasa a la pregunta por las maneras de ver y de percibir. La afirmación de la película es que una persona ve no solo con sus ojos, sino también con su mente. ${ }^{47}$ Un rodaje se prepara en la cabeza, y la médula del arte cinematográfico radica en el imaginar planos y escenas, tal como Gabor lo demuestra en la secuencia con doña Eulogia: cuando todo el equipo implicado en el rodaje esté al borde del lago, Gabor plantea la escena tal cual porque ya la tiene en la cabeza $(50: 14) .{ }^{48}$ Esta importancia de la imaginación en el arte cinematográfico lleva automáticamente a la pregunta más amplia sobre qué tipo de realidad se ve en una película: ¿algo ya existente reflejado o algo nuevo construido? Así, por ejemplo, el documental enseña al espectador cómo se crea un ambiente de madrugada a mediodía mediante la iluminación. Pero la intención de Gabor no es inventar un mundo paralelo, todo lo más admitir pequeños retoques a la realidad. ${ }^{49}$ Distingue tajantemente modificación de mentira: se niega rotundamente a falsificar la historia de Eulogia, que no es operable en la realidad pero

45 Gabor recuerda los planos de sus películas y de películas ajenas con una memoria asombrosa; un director de cine, que se entrevista en el documental, afirma sobre Gabor: "Es como una enciclopedia mental" (11:21).

46 Antes del viaje a Bolivia, Alfie se da cuenta de que Gabor ya está rodando dentro de su cabeza cuando este le describe sus ideas con dibujos en la arena (20:00).

47 En una entrevista, Gabor afirma: "Hablar de cómo se puede fotografiar sin ver es entrar en un terreno casi filosófico: ¿qué es ver? ¿vemos con nuestro cerebro o con los ojos?̨ंcuánto pertenece a cada parte?” (Camera\&light 2014).

48 Gabor afirma: "Cuando preparamos un proyecto como director de fotografía, una buena parte de esta preparación la pasamos imaginando situaciones y poco a poco acumulando información para imaginarlo mejor" (Camera\&light 2014).

49 Gabor está en contra de las mentiras rotundas; 'anticipar' la curación del panadero, por ejemplo, que se va a operar más tarde por cuestiones de la diabetes (52:18), no le parece éticamente sospechoso. 
que Alfie quisiera retratar en el clip como curada de su ceguera (42:28-42:47). Alfie argumenta con las exigencias de un clip promocional, Gabor, con los límites éticos.

La inclusión en Gabor no es artificial sino necesaria: Gabor es un elemento indispensable del equipo y además, el protagonista del largometraje. Integra literalmente el equipo de filmación como jefe de fotografía y a veces también, de codirector. ${ }^{50}$ En la primera parte, es el perro guía Gustav su acompañante de confianza, en la segunda, el mismo Alfie. Su espíritu de equipo se condensa en la imagen del pedalear en el tándem que ambos montan, acompañados por el perro (18:57). Gabor subraya que la inclusión debe contar también con el respaldo del equipo con el que uno está. ${ }^{51}$

En la película se sondean los límites que plantea la discapacidad de Gabor, tanto sus insoslayables inconvenientes como las oportunidades que brinda. La normalidad, expresada en el clip donde los ciegos deben transformarse en videntes, se observa desde la perspectiva de la inclusión, o sea, desde el largometraje donde el ciego trabaja al lado del vidente con igualdad de derechos. Gabor crea un contexto en el que cuadran todos, los videntes y los invidentes: combina la inclusión con integración y diferenciación. ${ }^{52}$ Este contexto no es transferible a cualquier situación, siendo las premisas del rodaje muy particulares. No obstante, el mecanismo subyacente enseña cómo una inclusión puede tener éxito sin refugiarse en un mundo paralelo: planteando una meta común (el objetivo final no es la inclusión sino una obra común, el clip) y buscar soluciones a los problemas que surgen en el camino en situaciones concretas. Un director de fotografía ciego que filma es una imagen concisa para nuevos espacios de interacción de mixed ability.

50 Puesto que el clip se propone hacer entender lo que siente alguien que recupera la vista después de años sin ver (2:24), pero sin caer en los tópicos de las películas que quieren sensibilizar (2:53), se necesita a una persona con experiencia con la ceguera. Varias veces, Alfie da razón a Gabor después de discutir con él sobre el concepto del clip.

51 En una entrevista después del rodaje, Gabor afirma que este es "la prueba de que en equipo se puede superar lo impensable” (Ojos del Mundo 2014).

52 Los elementos favorables a la inclusión son el género 'cine’ y el hecho de que Gabor ya tiene experiencias con el espacio del rodaje; afirma: "[Y]a conocía el espacio porque había rodado bastante en este tipo de escenarios, de ambientes y de climas" (Camera\&light 2014). 


\section{Conclusión: la inclusión como manejo de la ambivalencia}

Ambas películas analizadas incluyen a actores con una diversidad funcional real, enfrentan los tabúes y los prejuicios y buscan nuevos caminos más allá de los estereotipos de 'vencer' la discapacidad o de compensarla. Las relaciones entre personas con y sin diversidad funcional no son asimétricas sino recíprocas. Mientras que Campeones introduce un tabú sobre la realidad del cuerpo, Gabor aborda continuamente las limitaciones del cuerpo. Campeones inventa una inclusión perfecta en un mundo paralelo, Gabor muestra una inclusión imperfecta en un mundo específico, pero real. Campeones concibe la inclusión desde la normalidad, mientras que Gabor observa la normalidad desde un personaje incluido, de manera que no solo incluye sino que también integra la diversidad funcional. Solo en Gabor el protagonista modifica las exigencias de un rodaje normal, creando materialmente su propia película. Este tipo de inclusión ensancha el espectro de formas comunicacionales y subraya la diversidad funcional como potencial. Brinda una experiencia innovadora con una forma de inclusión en un espacio (estético) común.

Una inclusión con integración y diferenciación significa que una película no trata solamente de la discapacidad o se apoya en actores con discapacidad sino que las personas con y sin diversidad funcional negocian las reglas de la historia narrada. En este sentido, una película inclusiva constituye un 'espacio de juego' para nuevas experiencias con la discapacidad y para nuevas perspectivas sobre ella. Permite que surjan nuevas imágenes en los imaginarios de los espectadores que pueden servir de puntos de referencia también en la vida social cotidiana, y el marco ('frame') que condiciona la percepción de la discapacidad se ensancha. ${ }^{53}$ Como se ve en los ejemplos analizados, la inclusión se enfrenta a muchos retos y requiere más un espíritu cibernético (a la vez creativo y responsable) que uno que busque reglas que siempre valgan. Requiere también espacios como el cine para 'ensayar' los distintos tipos de inclusión que no arrojen tabúes sobre el lado negativo de la diversidad funcional ni sobre la ambivalencia en las reacciones frente a él. Todas las emociones que salen a la luz pueden manejarse de manera constructiva.

La inclusión es un intento genuinamente paradójico de tender puentes entre exigencias sociales contradictorias. Se parece a una autopoiesis que avanza mediante trial and error y contra la resistencia de la materia y de las convicciones

53 Sobre el poder de los marcos, los puntos de referencia y las, "anclas" de la percepción véase Kahneman 2012. 
estereotipadas. Por eso es un proceso en movimiento, o sea, un aprendizaje continuo en lo concreto y una empresa sensible a los contextos. Necesita sistemas de comunicación abiertos, espacios de diálogo y de experimentación. Los peligros están siempre al acecho: la moralización (que suprime la ambivalencia, volviéndola más peligrosa), la compasión y el paternalismo (que asimilan lo diferente a la norma), o el escarnio (que estigmatiza lo anormal). La inclusión es un desafío a la imaginación cinematográfica.

\section{Filmografía}

Alfie, Sebastián. Gabor (Argentina/España). En: https://www.documaniatv.com/ arte-y-cine/gabor-video_ed2e39c8e.html [08-10-2018].

Fesser, Javier. 2018. Campeones, DVD: [Universal City, Calif.], Universal Studios.

\section{Bibliografía}

Albrecht, Gary L.//Seelman, Katherine D./Bury, Michael (eds.). 2001. Handbook of Disability Studies, Thousand Oaks: Sage.

Barker, Clare/Murray, Stuart. 2018. "Introduction: On Reading Disability in Literature", en: Clare Barker/Stuart Murray (eds.), The Cambridge companion to literature and disability, Cambridge: Cambridge University Press: 1-13.

Camera\&light. 2014. “Gabor, fotografiar sin ver [06.01.2015]", en: https://www. cameraandlightmag.com/noticias/gabor-fotografiar-sin-ver/1\# [28-09-2018].

Cloerkes, Günther. 2014 [1984]. "Die Problematik widersprüchlicher Normen in der sozialen Reaktion auf Behinderte", en: Jörg Michael Kastl/Kai Felkendorff (eds.), Behinderung, Soziologie und gesellschaftliche Erfahrung, Wiesbaden: VS: 121-140.

Cruz Hoyos, Santiago. 2016. "Gabor Bene: la vida de un director de fotografía ciego", en: El País (28.8.2016), https://www.elpais.com.co/entretenimiento/cultura/ gabor-bene-la-vida-de-un-director-de-fotografia-ciego.html [19-09-2018].

Europa Press. 2018. “Campeones' o cómo entender en dos horas de cine la 'verdad' de la discapacidad intelectual', en: 20minutos (15.04.2018), https:// www.20minutos.es/noticia/3314444/0/campeones-como-entender-doshoras-cine-verdad-discapacidad-intelectual/ [24-09-2018].

Felkendorff, Kai. 2003. "Ausweitung der Behinderungszone: Neuere Behinderungsbegriffe und ihre Folgen", en: Günther Cloerkes (ed.), Wie man behindert wird. Texte zur Konstruktion einer sozialen Rolle und zur Lebenssituation betroffener Menschen, Heidelberg: Winter: 15-52. 
Goffman, Erving. 1991 [1963]. Stigma, New York: Simon \& Schuster, https://soth.alexanderstreet.com/cgi-bin/SOTH/hub.py?type=getdoc\& docid $=$ S10023894-D000004 [11-10-2018].

Grue, Jan. 2015. Disability and Discourse Analysis, Farnham: Ashgate.

Hartwig, Susanne. 2016. "Andere Geschichten über geistige Behinderung? Die Spielfilme Le huitième jour (1996), Yo, también (2009) und León y Olvido (2004)", en: Germanisch-Romanische Monatsschrift 66, 2 (2016): 225-240.

Hartwig, Susanne. 2018. "Introducción: representar la diversidad funcional", en: Julio Checa/Susanne Hartwig (eds.), ¿Discapacidad? Literatura, teatro y cine hispánicos vistos desde los disability studies, Frankfurt a. M. et al.: Peter Lang: 7-21.

Kahneman, Daniel. 2012. Thinking, Fast and Slow, London: Penguin.

Kastl, Jörg Michael. 2015. "Inklusionsrituale und inklusive Communitas. Paradoxien der Behinderung in der modernen Gesellschaft", en: Robert Gugutzer/Michael Staack (eds.), Körper und Ritual, Wiesbaden: Springer VS: 263-287.

Kastl, Jörg Michael. 2017. Einführung in die Soziologie der Behinderung. Ein Lehrbuch, $2^{\mathrm{a}}$ ed. compl. rev. y augm., Wiesbaden: Springer VS.

Korczak, Dieter. 2012. “Einleitung”, en: íd. (ed.), Ambivalenzerfahrungen, Kröning: Asanger: 7-10.

Lüscher, Kurt. 2012. "Menschen als 'homines ambivalentes"', en: Dieter Korczak (ed.), Ambivalenzerfahrungen, Kröning: Asanger: 11-32.

Luisjo. 2018. "Campeones, humor emotivo", en: revista atticus (23.04.2018), http://revistaatticus.es/2018/04/23/critica-pelicula-campeones-de-javierfesser [04-10-2018].

Mitchell, David T./Snyder, Sharon L. 2000. Narrative Prosthesis. Disability and the Dependencies of Discourse, Ann Arbor: The University of Michigan Press.

Murphy, Robert F. 2001 [1990]. The body silent, New York/London: W. W. Norton.

Murray, Stuart. 2008. Representing Autism. Culture, Narrative, Fascination, Liverpool: Liverpool University Press.

[Ojos del mundo]. 2014. "Gabor Bene, director de fotografía [septiembre 2014]", https://www.ullsdelmon.org/es/entrevistes/gabor-bene-director-defotografia-septiembre-2014/ [08-10-2018].

Osteen, Mark. 2008. "Autism and Representation. A Comprehensive Introduction”, en: íd. (ed.), Autism and Representation, New York et al.: Routledge: 1-47.

Ravaud, Jean-François/Stiker, Henri-Jacques. 2001. "Inclusion/Exclusion. An Analysis of Historical and Cultural Meanings", en: Albrecht/Seelman/Bury 2001: 490-512. 
Schönhuth, Michael. 2011. "Entwicklungszusammenarbeit", en: Fernand Kreff/Eva-Maria Knoll/Andre Gingrich (eds.), Lexikon der Globalisierung, Bielefeld: transcript: 57-61.

Westerholm, Robert I./Radak, Laura/Keys, Christopher B./Henry, David B. 2006. "Stigma”, en: Gary L. Albrecht (ed.), Encyclopedia of Disability, vol. IV, Thousand Oaks: Sage: 1502-1507. 



\title{
Ryan Prout \\ University of Cardiff \\ Still Waters Run Deep \\ Disability Counter Currents in \\ La piscina (2012)
}

\begin{abstract}
The focus of my contribution is La piscina, directed by Carlos Quintela (2012). The film stands out as one of the few titles made in Cuba to feature disabled people and to represent issues of functional diversity. I preface a close reading of the film, and of the responses to it by Cuban and overseas scholars and viewers, with an overview of the bureaucracy by which disability support and advocacy is organised in Cuba. This illustration of organisational context, and of the polemical repackaging of representation of Cubans with disabilities, establishes the challenging premise represented by Quintela's cohort of four adolescents with different disabilities.

Using the work of Michael Bérubé I argue that the alienating anti-narrative of La piscina serves not only a rhetoric of obliquity but also the politicisation of disability storytelling in film. In my interpretation I connect the peopling of the film's location with disabled individuals to the social history of swimming pools and public space. The swimming pool indexes prejudices and progress as a site that has registered changing conventions about who is included by, and who is excluded from, civic projects.

I deploy La piscina to query the access that disabled people have had to the swimming pool qua public space. By setting Quintela’s film against work by Elmgreen and Dragset at the Whitechapel Gallery, I suggest that the decline in civic infrastructure traverses consumerist and residually socialist societies.
\end{abstract}

Keywords: Cuba, municipal swimming pool, public space, narrative incompletion, disability metaphor

\section{Introduction}

\section{Statist Disability Structures and Keys to the Real Cuba}

Cuba is a signatory to the convention on the rights of disabled people, of 2007, though, as of 2014, to the best of my knowledge, it had not signed up to the optional protocols that are appended to this convention, and which would, for example, facilitate international cooperation in terms of monitoring and observation. The Cuban constitution guarantees that citizens should not be subject to discrimination but there is no constitutional guarantee of the rights of disabled people or legislation that would protect them specifically. The structures that 
address disability in terms of collectives and associations sit under the Ministry of Justice; mental and learning disabilities seem still to come under medicine. 'Organisations' essentially means state organisations in Cuba because there is suspicion of NGOs and of networks established abroad, although the official line is that such structures are unnecessary because they duplicate what the state already does.

The national census carried out in 2012 identified that five percent of people in Cuba have some sort of disability or padecimiento, to use the terminology of the census. 51 percent are women, and 49 percent men. There is no granular disaggregation of the data so that we cannot read the figures against race, age, or geographical location, in any detail, for example. However, the data do show that of the 5 percent of Cubans with a disability, 5.6 percent of these are children aged 14 and younger, and that disability is more prevalent in the 45 plus age group (Oficina nacional de estadísticas 2012).

There are three state organisations in Cuba that allow disabled people to associate. One is La asociación cubana de limitados físico-motores (ACLIFIM), founded in 1980, another is the Asociación nacional de ciegos y débiles visuales (ANCI), formed in 1975, and the third is the Asociación nacional de sordos (ANSOC), established in 1978. As of 2014, there was no association analogous to ACLIFIM, ANCI, and ANSOC to meet the needs of people with mental and learning disabilities. We can see, therefore, that in terms of organisational structure, Cuban state policy sees disability rather selectively and divides it into physical handicap and sensory impairments. The fact that Cuba's network of psychiatric hospitals seems to be a focal point for people with mental and learning disabilities suggests that the medical model still prevails in this area.

When we look at the definition of who ACLIFIM claims to represent, we can already see some exclusion: "Nuestra organización acoge a personas con discapacidad evidente y permanente en una o más extremidades, que no sea provocada por el desgaste propio de la edad (vejez) o asociada a retraso mental, y personas con amputación de uno o más miembros" (ACLIFIM 2003-2016, emphasis added). Age-related infirmity and mental disability, then, are not part of ACLIFIM's remit and this approach sits rather at odds with the social model of disability that one might assume would be prioritised by a revolutionary and socialist government with a putatively progressive agenda. Furthermore, according to ACLIFIM, it represents 74000 people, but this is only 40 percent of the cohort in whose name, according to its own exclusive definitions, it could potentially speak (Flores and Diversent 2014). Similar discrepancies in figures can be found when we look at ANSOC and ANCI. When all the figures are 
consolidated, it becomes apparent that only 22 percent of Cuba's people with disabilities are associates of the three state structures (Flores and Diversent 2014).

Human rights organisations inside Cuba, such as Cubalex, have been critical especially of the difficulties created by the paucity of data in evaluating how successful mainstreaming of education has been for people with disabilities. The constitution guarantees education for all, without discrimination, and critical voices find that there is a wide gulf between legislation and compliance. There is a lack of data on the distribution of young people with disabilities between mainstream and special schools, but what is known is that where special schools exist they are also used to accommodate both the education of children with behavioural challenges and schooling for those who are not disabled but learn at a different pace than the mainstream.

There is very little middle ground in what can be discovered about the situation of disabled people in Cuba: either the social context is portrayed as utopian, or as hellish. To illustrate this one could compare, for instance, the view of the situation for disabled people projected by Cuba's Ministry of External Relations with dissident journalist Yusimí Rodríguez's reports on the plight of people with disabilities in Havana. The Ministry's glowing account stresses the enormous expansion in the number of dedicated schools created since 1959 and emphasises the national action plan's ambition of preventing disability. It suggests that disabled people are well-integrated in the workforce and in society generally (Minrex 2001). This summary of the achievements claimed by the revolution in its social integration of people with disabilities is titled 'Cuatro décadas de amor y bondad', a heading that conflicts with the content of the article inasmuch as it positions people with disabilities, in a very unreformed way, that is, as needy recipients of caritas.

By contrast, Rodríguez discovers people like Jorge Luis Moreiro, a wheelchair user, who tells the journalist that he was accused of 'asedio al turismo' for trying to interest visitors in goods that he has a licence to sell. Remarking on the gift of a consignment of wheelchairs from a foreign donor, he says "Lo que pasa es que cuatrocientas sillas no resuelven el problema donde hacen falta cien mil" (Rodríguez 2013b). When she sees an elderly amputee being roughed up by the police in a touristed area of Havana, Rodríguez asks herself “ $¿ Q u e ́$ daño puede hacer ese infeliz? Dejar la cara fea de la realidad cubana al descubierto, sin maquillaje" (Rodríguez 2013a). This latter comment demonstrates the over determination of disability in Cuban social politics as either evidence of an authentic and hidden social disintegration or as proof of a kindly regime that has infinitely improved conditions for its disabled subjects (a question to which I return in a later section). 
In contradistinction to the troubling testimonies of the isolation and impoverished living conditions of people with disabilities narrated by Cubalex and dissident journalists, La piscina, made in 2012 by Carlos Quintela, brings together four disabled people in a swimming class led by a former athlete who did not make it into competition and now works as a coach. The film is uncompromisingly aestheticising of its subjects. But it also engages with the politics of disability in Cuba, simply by grouping together a cohort of individuals whose disabilities traverse physical and cognitive impairment. The sparse dialogue, and refusal to fill in disability back stories, makes the film's approach to disability very different from the emphasis on the personal stories related both by Yusimí Rodríguez and by Yaremis Flores and Laritza Diversent in their deposition to the Inter-American Human Rights Commission in 2014. As I will go on to argue, however, the withholding of the disability back story can itself be seen as a political gesture and as a way of rupturing the conventions of disability narrative.

The coach's four tutees, Diana, who has one of her legs below the knee amputated, Dany, who has Down's Syndrome, Rodrigo, who has impaired gait and movement, and Óscar, who is mute, and perhaps on the autism spectrum, are all good swimmers. Since many able-bodied people cannot swim, focusing on people with disabilities who can swim, easily moving about in another material dimension, queries the able/disabled binary and indicates that despite its highly aestheticised register, La piscina also has some intent within the discourse of disability politics.

The film opens with a perplexing extended scene of an outdoor swimming pool reflecting a turbulent early morning sky. The script had set the action on a cloudless day in August but delays to the shooting schedule meant it was autumn before work began on the project and this is reflected in the overcast skies seen in the long opening sequence (Izquierdo 2012). At a very leisurely pace, the scene is peopled with the coach, and his four charges, and, later, with secondary characters, including a team of athletes, parents, and a competitive trainer. The action is punctuated more by the changing temperament of the sky on a tempestuous October day, than it is by narrative developments. When the athletes arrive to use the pool, the group of five, including the coach and the four disabled young people, head off for lunch. They come back, argue, tease each other, and Diana tries to make the mute Óscar speak by dunking him under water. The swimmers are collected by their parents, and the film ends.

Although La piscina was supported by ICAIC, it seems not to have been promoted very heavily in Cuba. Could this be because, aside from its aestheticising register, it also intends something political? Its desegregation of the division between sensory, physical, and mental disability implicitly challenges the model 
that sits under the state's institutional syntax of disability. The film gives us no idea of the barriers - physical, social, and conceptual - that its protagonists face beyond the pool, and this loud omission speaks to the gulf between a rhetoric of accessibility and a decaying material environment that can be hostile to all, able and disabled alike. Quintela allows us to see the four disabled protagonists as individuals: there is as much difference between them as there is between any one of them and the ableist norm. Diana mocks Óscar's muteness; he in turn physically parodies her gait. What conjoins them most is their shared alienation from the mainstream.

In the sections that follow, I look firstly at how this narrative of detachment has been read by critics, scholars, and viewers, and also at the director's own gloss on decisions he made in making the film. Secondly, I focus on the setting of the film-a swimming pool open for public use-as a registration of (non-) inclusivity and of the retreat from municipality, and thus from a social model that had a civic and democratising purpose that would potentially have been of benefit to people with disabilities if their claim to the public spaces represented by municipal pools had been heeded.

\section{Critical Reviews of La piscina}

\section{Disability Metaphors and Disability Absence}

Antonio González brackets the cinematic aesthetics of La piscina with the work of Tarkovski, thus signalling the meditative and demanding nature of the film. The relationships it describes are, in González's words, "cuadrilateral" and the film's format could also be said to be squared, rectangular (since the pool has an aspect ratio of approximately 2.5 , like widescreen film), or cubist, inasmuch as it presents a poly-faceted view of disabilities.

González describes the film space as a "bastidor" and, arguably, this aesthetic device compels the viewer to adopt a meditative, reflexive, approach to what unfolds and makes one query how, where, and when one looks at people with disabilities. The film features almost no medium shots of individuals and instead shuttles between close-up portraits and wide shots. Raúl Rodríguez, the film's DOP, says of this practice: "El equipo de realización pretendió acercar o alejar al público de los personajes; de ahí la presencia mayoritaria de planes panorámicos y generales en el filme" (Orgado 2012).

By emphasising the framing nature of cinematic and visual representation, Quintela clearly wants to put disabled people into the picture, and his choice of this swimming pool as a location speaks to that intention. It allows him to 
present his four disabled characters against a canvas that centres the body and its movements. In a pool, swimmers are pictured, rendered as subjects in a tableau. Inviting us to look at the bodies of disabled people in the setting of a swimming pool, Quintela also poses the question of whether a space usually thought to be a levelling one for people at large has the same effect when it comes to ableism (see Fig. 1). As Jeff Wiltse notes: "Pools force swimmers to cast off most material accoutrements of life [...] and the outward signs of status that define people's identity in a consumer society" (2007: 208). But, is disability an accoutrement that can be cast off? And how does the disabled body sit alongside public swimming, an activity, which, as Jeff Wiltse also says, "Eroticised public spaces [with the result that] public objectification of the body became implicitly acceptable" (2007: 5).

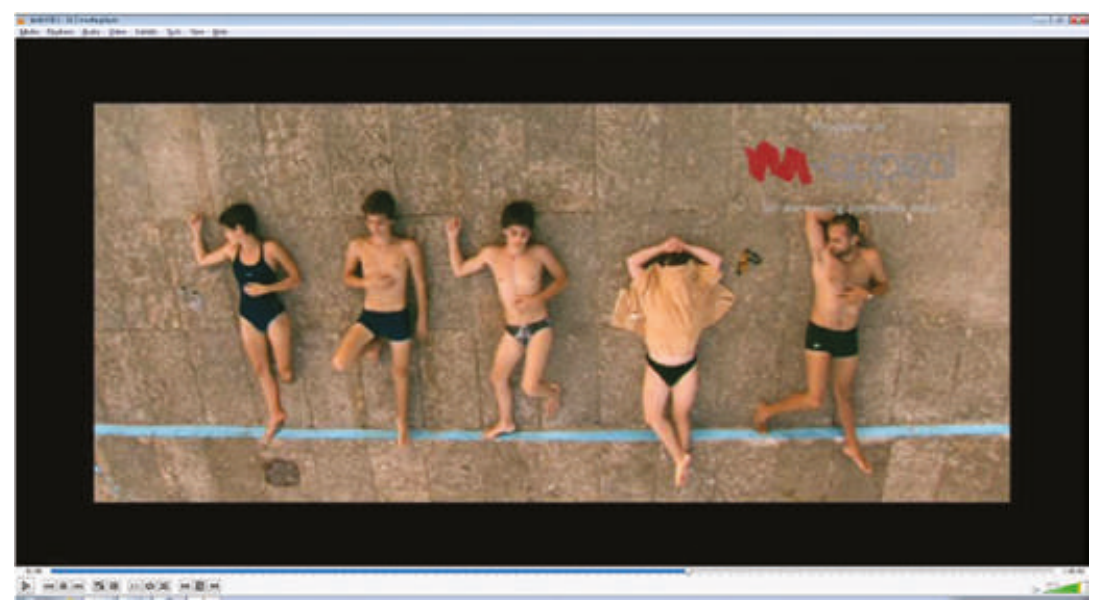

Fig. 1: Screen Shot from La piscina. Diana, Rodrigo, Óscar, Dany and Esteban on the poolside

Since the very motile characters would be rendered static by a painting, to see the area framed by the pool as redolent of a film negative (as well as a canvas) takes account of these being moving images. The lengths swum by the protagonists lead nowhere, however, and the movement in the film does not correspond to a formulaic narrative arc, or journey. Like the bodies of the swimmers, time is partially suspended in La piscina and hence the narrative structure departs from the conventions of development and ontological growth: we are better acquainted with the characters after an hour in the company of their representations, but 
we do not know very much more about them biographically. Magali Kabous interprets this epistemological aporia as the calm around the bubbling storm of adolescent rebellion that occasionally surfaces in the characters' actions and declamations. Speaking to Samuel Orgado, the director himself defines the film as a reflection on incompletion:

La piscina es un lugar donde las cosas pueden no suceder [...] Es una expresión de lo incompleto [...] Simula ser incompleto por su lenguaje y contenido. Tiene que ver con las cosas que no conducen a ningún punto y que a la vez se relacionan con los problemas sin solución. (Orgado 2012)

He connects this sense of pseudo-incompleteness with a state of being that now exceeds waiting, and therefore the possibility of change, presumably:

Ya pasaron [los caracteres] esa etapa de esperar un cambio; simplemente están ahí y permanecen en ese sitio y a veces se aburren, a veces no, a veces hacen chistes. Es el espacio que tienen, en la piscina simplemente se está. (Usi 2013)

The sense of floatingness, of temporal suspension, and of a fate existentially and arbitrarily determined that Quintela ascribes to his characters links them to his description of Cuba: "[E]s una isla corcho que está flotando y va de un lugar a otro" (Usi 2013).

An inference that will naturally be drawn from the director's segue between characters who seem to exist outside the normal passage of time and an island that bobs about in the sea like a cork is that in some way Diana, Rodrigo, Dany, and Óscar represent the insular Cuban population, floating about with no autonomous direction. And, since four of the five central characters in La piscina are disabled, a further inference would be that the film uses disability as a cipher for Cuba's maladjusted political and historical development, even if the director resists this reading. He says, in a way that seems to pre-empt such equations: " $L a$ piscina [no] se regodea en las discapacidades de los personajes. Pretende asumirlos como lo que son, y nada más" (Orgado 2012).

In the comments stream on web reviews of La piscina, some citizen critics have seen in La piscina a submerged indictment of Cuba's flaws. For example, Yasser writes:

[Habanastation, de Ian Padrón] puso en evidencia los altos valores que existen en nuestros humildes infantes, pero al parecer son los personajes de niños las únicas que ver [sic] nuestros directores de cines con un potencial para poner en evidencia este tipo de valores que recorre la isla en todas las edades como diciendo de manera subliminal: "esto existe porque son unos puros inocentes ignorantes de la realidad". (Comments appended to Izqierdo 2012) 
González also has recourse to the notions of the subtextual and of a clandestine semantic relationship between the viewer and the filmmakers when he says that: "La piscina propone al espectador un ejercicio empático y decodificador." He sees an osmosis between the pool and the swimmers such that their stagnation is shared. He finds, furthermore, that their behaviours (and in a sense, their disabilities) are coping strategies:

Las aguas de la alberca están tan estancadas como las existencias de los personajes, quienes se protegen de sus miedos, impedimentos y reales sentimientos con la mudez renuente [...] la agresividad dominante [...] la burlesca frivolidad [...] el más sincero espejismo [...] y la indiferente resignación. (2012)

While this decoded reading only implies that Dany's infatuation with Diana is, or should be, illusory, that Óscar's muteness is elective, and Rodrigo's crippled gait is a burlesque, González's interpretation clearly aligns a stagnant environment-the swimming pool, and the larger Cuban context—-with the people who exist in it, namely the four disabled characters, and, by extension, a wider population, as if to say that Cuban youth are amputees; cripples; unable to speak; a cohort that learns at a different pace. If one were to object to González's interpretation, which is largely sympathetic to the film, it would be on the grounds that it burdens people at the margins of ableist normativity with soaking up the spill over of the signs and effects of Cuba's arrested economy.

Taken alongside each other, what these interpretations seem to show is a decentring of disability in responses to the film. To an extent, this may derive from the fact that there is little context for a Cuban cinema about disability. From the point of view of the cinema-going public in Cuba-insofar as this can be gleaned from comments posted to reviews by readers who write from an islandbased perspective-the film's opacity and its disability theme function as dog whistles to alert those in the know to material that departs from the officially approved scripts dictated by the regime. Just as Yusimí Rodríguez identifies the subject of one of her pieces on disabled and indigent people with a transparent vision of Cuba shorn of all cosmetic enhancements, so these readers identify in Quintela's focus on disability a will to show Cuba as it really is and also to make an authentic Cuban cinema:

Este son los tipos de argumentos que deberían abundar en las películas cubanas. Muchas historias se pueden armar con personas con sueños e ilusiones como pueden tener los personajes de esta película y creo que son más representativos de nuestra nación. Sin embargo los directores de cines cubanos se esfuerzan mucho por otros temas donde siempre están presentes el homosexual o travestis, el hombre que quiere emigrar, o el 
revolucionario vestido de verde con mente obtusa. (Yasser, comments appended to article by Izquierdo 2012, emphasis added)

In this reading, disabled people, and disabled youth, in particular, are tied to cinematic verisimilitude. Furthermore, the representation in Cuban cinema of other minorities, notably LGBT people, is considered to be indicative of an inauthentic Cuban cinema such that there is no sense that someone in Cuba could be both disabled and gay, or disabled and trans. Yasser goes on to say that "La Cuba actual en muchos aspectos está desaparecida del cine cubano." Making disability visible is therefore tantamount to restoring to Cuban cinema the subject that is putatively its medium. From being sidelined as an uncomfortable reminder of failed social policies in the view of journalists such as Yusimí Rodríguez, here visible disability is over-determined with the responsibility accruing to an emissary of authentically Cuban content more usually evacuated from the national cinema.

I would also argue here that the relative oversight of the disabled characters' specific and diverse disabilities-collectively metaphorised as stagnation by González; made a proxy for an otherwise invisible Cuban reality in the comments cited above; and rendered absolutely opaque by Quintela's analysis-devolves from a reticence to connect the film's unconventional narrative and its unusual chronology with disability and functional diversity. Reading Michael Bérubés work on narrative and disability, however, would encourage us to exercise precisely this interpretive gesture. As Bérubé observes, "Disability compels us to understand embodiment in relation to temporality" (2005: 570) and, by disrobing its disabled characters, situating them in a reiterative temporality, $\mathrm{La}$ piscina insists on the convergence of alternative gauges of time, on the one hand, and bodies and minds with impairments, on the other. And just as embodied disability insists on temporality, in narratives more conventional than La piscina, as Bérubé observes, it also "demands a story" (2005: 570).

Quintela's film frustrates the viewer not only because the action remains in one place for almost its entire duration, but also, I would argue, because none of the disabled characters, and none of the secondary characters who might take it upon themselves to speak for them, articulates any kind of disability back story. La piscina draws attention to the staples of many narratives with a disability theme by leaving them out.

The audience for the film becomes like Diana when she tries to force a story out of the mute Óscar. We want it to speak disability genesis to us, but it refuses to do so, its refusal closely linked to a cripped, or disabled, temporality. Elsewhere I have suggested that contemporary Cuban film uses a rhetoric of 
obliquity to circumnavigate the imprecise limits of tacit censorship (Prout 2017). While I believe that this contention also holds true of Quintela's film, the incomplete nature of the narrative (as the director himself styles it) also responds to an intervention in the politics of disability representation. The film's accentuated temporality and studied withholding of proxy "self"-expression also functions, I suggest, as an invitation to re-read the conventions of disability narrative and, in particular, the acquiescence of many stories of functional diversity to the demand that people with disabilities account for themselves.

Bérubé identifies unorthodox narrative chronology, self-reflexivity, and questions around the imperative to uncover causality as aspects of narratives that deploy disability to explore narrative conventions, especially around self-consciousness (2005: 576). I argue here that La piscina displays these features in its unconventional portrait of functionally diverse characters. Underneath the prolonged interruptions in the dialogue, and below the apparently etherised sky and spooked narrative clock, there are lively currents running counter to the flow of more conventional representations of disability. Obliquity, then, addresses itself both to the regime of censorship inside the Cuban film establishment, and to the epistemological regime that dictates knowledge of disability causality. By bringing to the foreground the disabling, or cripping, of the conventional expansion and condensation of real time to screen time in La piscina, we see how the film invites us to attend to the relationships between embodied disability and temporality on which Bérubé insists.

\section{Municipality and the Abandoned Swimming Pool}

\section{Indices of Social Cohesion}

The water that González finds to be stagnant would not literally have been so, since, as the director notes in his conversation with Eva Usi, the pool where $L a$ piscina was filmed was not filled until three days before shooting was scheduled to begin, due to problems with the machinery on site. There was little time for rehearsal, and Quintela speculates that aspects of the film might have been more accomplished had this not been the case.

In an effectively played scene, Diana, Dany, Rodrigo, and Óscar all become subdued when a squad of athletes arrives in the middle of the day to take over the use of the pool. Each cohort acts as if the other did not exist. The presence of the athletes reminds us that the venue where the film was shot, the Marcelo Salado swimming school, was intended primarily to develop and nurture potential Olympic swimmers and Cuban medal winners. What looks like a municipal 
swimming bath had an elitist and nationalistic purpose. While professional sports do not exist in Cuba, Cuban athletes still want to win and sports culture embodies physical norms and ideals. This is another of the contradictions between rhetoric and practice underscored by La piscina's juxtaposition of two cohorts of swimmers, and might perhaps have alienated the Cuban institutions from the film.

The Escuela nacional de natación Marcelo Salado was, prior to the revolution in 1959, the site of the Balneario universitario. Established in 1965, the school was intended to train swimmers for competition and is linked to the Olympic medals won by Cuban swimmers Rodolfo Falcón and Neisier Bent in 1996, at the Atlanta games. By the time the crew of La piscina were shooting the film, however, the facility had gone in to decline, as evidenced by the issues they encountered simply with filling the pool with water. Four years later, writing for Cubanet, Manuel Guerra Pérez described a run-down set of installations where only one of the four pools remained operational. Two years later, in an article for Diario de Cuba, the same journalist reports the further decline of the Marcelo Salado school: "Se encuentra en pésimo estado debido a la falta de mantenimiento [...] No tienen climatización, las áreas deportivas están destruidas [y] el gimnasio no cuenta con los aditamientos para realizar ejercicios" (2015).

The illustrations that accompany the article show empty pools falling into disrepair, including one that looks like the location used for La piscina. The stagnation and crumbling cement that González Rojas saw in the film had by 2017 become a material reality. Despite the ideological differences between communism and capitalism, the decline of a facility such as the Marcelo Salado school, and speculation that the site will be turned over to tourism, indicates convergences between the two political systems in the latitude allowed for the process of gentrification and for the privatisation of previously public spaces.

There is some irony here inasmuch as in the first flush of the revolution pools as privatised spaces represented the apotheosis of the bourgeoisie. In Gutiérrez Alea's Memorias del subdesarrollo (1968), for example, scenes of Sergio and Pablo lounging about beside the pool at their private club epitomised the defects of their class, and the underdeveloped consciousness that needed to become progressive if the former upper middle classes were to have any chance of fitting in to the socialist society. Nothing spoke of inequality and of segregation by income as eloquently as the private pool. In the socialist world view, on the other hand, the municipal pool, open to the public, indirectly represented the triumph of the secular over the religious order. Following the demolition in 1931, on Stalin's 
orders, of Moscow's Cathedral of Christ the Saviour ("a refuge of delusion"), the world's largest heated outdoor poor was built in the vacant footprint originally intended for the unrealised Palace of the Soviets. The pool, in its turn, was demolished after the collapse of the USSR to make way for a rebuilt cathedral (Mortsiefer/Pelzer 2016).

If there is an element of stagnation in La piscina, then, it anticipates the abandonment of the facility where it was shot within only a few years of its production. It also presages the calling into service of the empty public swimming pool as an emblem of the erosion of municipality and of public services.

This, for example, was the premise of the main exhibition space in DanishNorwegian artists Elmgreen and Dragset's 2018 show at the Whitechapel Gallery, in London. An entire section of the gallery was turned over to a simulation of an abandoned municipal swimming baths complex slowly falling into ruin. Signage and cultures suggested a 1970s aesthetic while leaves, dust, and masonry on the floor of the pool signalled decay and neglect. In its review of the exhibition, Time Out said:

The Whitechapel Gallery [...] will be turned into suites for the moneyed hipster elite to huff designer drugs in, and its pool will become an opulent spa. You probably didn't know the Whitechapel had a pool, but it does. Been there since 1901 [...] Hockney painted it back in the day, apparently.

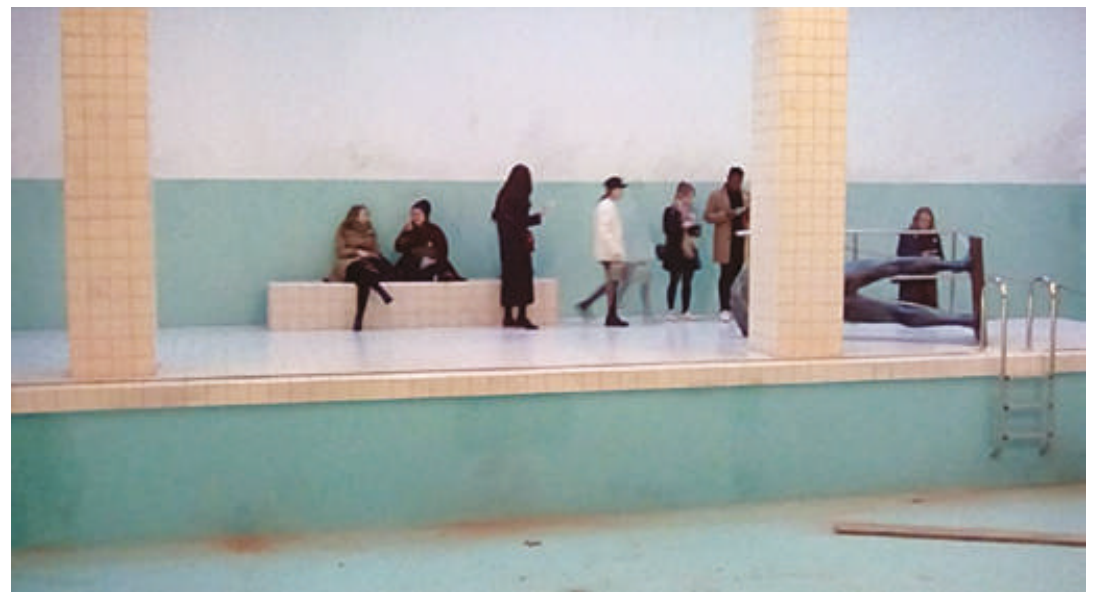

Fig. 2: Abandoned swimming pool installation. This is How We Bite Our Tongue exhibition at The Whitechapel Gallery, London, 2018 (Photo: Ryan Prout) 
If the Whitechapel venue had ever really included a pool, the putative transformation would be a credible one since it would fit with a pattern of previous redevelopment of municipal facilities for the purposes of gentrification, such as the conversion of the former Laurie Grove public baths in New Cross into a centre for contemporary art (Bennes 2018).

The closure of municipal bathing facilities matters, I would argue, because, going back to Ibsen's En folkefiende [An Enemy of the People] (1882), publically accessible pools have been perceived as sites that register the inclusiveness (or not) of communities and as a locus where social, environmental, and welfare policies are dramatised. The dispute in Ibsen's play over the fitness for consumption of the water in the spa articulates a debate about the health, transparency, and integrity of the local polity. In some respects, La piscina is heir to this trope as evidenced, not least, by the fact that the real world location of its fictional narrative has fallen into disrepair and registers a political and municipal failure, one seen, furthermore, by citizen journalists as indicative of the same self-interests, hypocrisy, and corruption that beset Ibsen's fractured community in An Enemy of the People.

The pool as an index of social health and inclusivity is a device to which Jeff Wiltse returns in Contested Waters, his history of swimming pools in America. Baths are an appropriate locus for an exploration of American social history, Wiltse says, precisely because "Community life [has been] fostered, monitored, and disputed at municipal pools" (2007: 6). Pools in America have registered the shift from a society segregated by class, at the end of the nineteenth century and the beginning of the twentieth century, to one divided more by race, leading ultimately to the retreat from municipal baths of affluent white people, first to exclusive clubs, and then to completely private facilities built at home.

By the 1990s there were four million private pools in the United States, as compared with fewer than 5000 in 1950 . What happens to pools, and whether they are centres of community cohesion, or facilities whose entrance policies are based on discrimination, reflects the politics of public space. While Wiltse writes about America, and with a particular attention to race, bearing in mind the running down of public facilities in Europe as well, what he says can be applied more generally:

The history of swimming pools locates the beginning of civic disengagement [...] Between 1950 and 1970, millions of Americans chose to stop swimming at municipal pools. This represented a mass abandonment of public space and was caused most directly by racial segregation. (2007: 205, emphasis added) 
The falling into desuetude of municipal facilities that has followed this privatisation is significant, Wiltse says, because "municipal swimming pools [...] allow ordinary and even marginalized members of society to participate in the production of public culture [which] would be less democratic without them" (2007: 208-209). Furthermore, Wiltse claims, in spite of the previous exclusionary practices that determined who could, and who could not, have access to public swimming pools, such facilities "can level social differences [...] and diminish the significance of economic inequality by affording all social classes access to some trappings of the good life" (2007: 208).

A similar idea is developed by Ann Lui in her essay on The Whitechapel Pool. The work reminds us, she says, of "[H]istories in which municipal swimming pools acted as sites of both inclusion and exclusion, indexing both prejudices and hopes about culture, class, sexuality, and race" (2018: 12). Noticeably missing from Lui's indexing of Elmgreen and Dragset's Thatcherised (and postThatcherised) pool is any reference to the role of the baths' space in determining how and when people with disabilities are included, or excluded, despite the fact that the question of physical in/accessibility would seem to suggest itself as an obvious factor determining the extent to which a space genuinely open to an entire public can achieve its inclusive aims.

Juxtaposing La piscina and The Whitechapel Pool lends the film narrative another political layer because it connects the marginalisation of Cubans with disabilities to the erosion of shared physical space, not only in the parts of the world that have already completely surrendered to consumerism, but also to the few remaining redoubts of an alternative economic structure. It also brings into focus the omission of questions of functional diversity from the study of swimming pools (through scholarship, or art) as a window on social history.

An adjunct to The Whitechapel Gallery is the sculpture of a man made in a classical style. It is turned on its side and has fallen to the ground, one of its upper limbs incomplete (see Fig. 2). If this speaks to the work's equation of the decline in municipal services with a disabled body politic, this use of impairment as metaphor is not reclaimed in Lui's analysis. Quintela's four disabled characters, by contrast, are living and motile testaments to the claim on public spaces of disabled people, excluded as much by disavowed ableist segregation as by physical impediment. Once in the water, the differences between the discrete impairments that characterise Diana, Dany, Óscar, and Rodrigo become less obvious and the syncopated movements that characterise them out of the water are more conventionally fluid in it.

Given a different material environment-exchanging the unforgiving fixtures of land and $\mathrm{O} 2$ for the flowingness and support of $\mathrm{H} 2 \mathrm{O}$ - there is a levelling 
effect between the disabled and the non-disabled and in this sense, Quintela's film encodes an almost utopian application of the social model of disability. With scenes of the relatively easy insertion of people with disabilities in the pool (albeit in dedicated and segregated hours), La piscina both reflects and differs from the swimming pool scenes in Lars Von Trier's Idioterne (1998). In the earlier film, the arrival of a group of people with simulated physical and cognitive disabilities tests the definition of "public" at a municipal baths in Copenhagen. The hostility with which the group's incursion is met indicates that the putatively public space demarcated by this Copenhagen pool is really one that defines an able-bodied and cognitively normative public, that is, a public with exclusions.

Like The Whitechapel Pool, La piscina has the feel of an incomplete or unwritten script, and indeed, the screenwriter, Abel Arca, relates that much of the draft screenplay was abandoned. Where The Whitechapel Pool creates "queer darkness" (Lui 2018: 21), or aporia, through its emphasis on abandoned municipal space, La piscina summons a similar effect in a non-linear narrative in which four young people, whose different impairments invoke the broadest meaning of disability, stake a claim to a putatively public space revolutionised in the name of equality of access. Quintela deliberately keeps the disability biographies of his characters in the dark and thus queers not only the space, but the generic conventions of the disability narrative.

\section{Filmography}

Gutiérrez Alea, Tomás (director). 1968. Memorias del subdesarrollo, ICAIC.

Machado Quintela, Carlos (director). 2012. La piscina, ICAIC Muestra Joven and Alter producciones audiovisuales.

Von Trier, Lars (director). 1998. Idioterne [The Idiots], Zentropa.

\section{Bibliography}

Asociación cubana de limitados físico-motores. 2003 [2016]. Untitled home page of website, http://www.aclifim.sld.cu/ [29-11-2018].

Bennes, Crystal. 2018. “Open to All”, en: Frieze 198 (October): 37-38.

Bérubé, Michael. 2005. “Disability and Narrative”, en: PMLA 120 (2): 568-576.

Flores, Yaremis/Diversent, Laritza. 2014. Presentation on Disability in Cuba on Behalf of Cubalex to the Comisión Interamericana de Derechos Humanos. 25 March. Recording available at https://www.youtube.com/watch?v=uDul_ qDnl3o. 
Frankel, Eddy. 2018. "Elmgreen and Dragset: This is how We Bite our Tongue Review., en: Time Out, https://www.timeout.com/london/art/elmgreendragset-this-is-how-we-bite-our-tongue-review [06-01-2019].

González Rojas, Antonio Enrique. 2012. "La piscina: como ondas en el agua”, en:Cinecubanoalapupilainsomne(23July),http://cinecubanolapupilainsomne. wordpress.com/page/153/ [12-04-2019].

Guerra Pérez, Manuel. 2015. "Escuela Marcelo Salado: El rostro de la natación cubana", en: Cubanet.org (23 May), https://www.cubanet.org/ actualidaddestacados/escuelamarcelosaladoelrostrodelanatacioncubana/ [24-11-2018].

Guerra Pérez, Manuel. 2017. “Adiós al Marcelo Salado", en: Diario de Cuba (8 July), http://www.diariodecuba.com/deportes/1499505239_32427.html [2411-2018].

Ibsen, Henrik. 2012 [1882]. Ein Volksfiend. Trans. Christel Hildebrandt, Stuttgart: Reclam.

Izquierdo, Jaisy. 2012. "En las aguas de La piscina”, en: Juventud Rebelde, http:// www.juventudrebelde.cu/cultura/2012-06-12/en-las-aguas-de-la-piscina [01-10-2018].

Kabous, Magali. 2015. "Vivir la propia revolución dentro de la Revolución", en: Cinémas d'amérique latine 23: 108-121.

Lui, Ann. 2018. "Elmgreen and Dragsets's Dream of Public Space at The Whitechapel Pool", en: Laura Smith (ed.), Elmgreen and Dragset: This is How We Bite our Tongue, London: Whitechapel Gallery: 12-23.

Ministerio de Relaciones Exteriores de Cuba. 2002. "Los discapacitados en Cuba: cuatro décadas de amor y bondad", en: http://anterior.cubaminrex. cu/Mirar_Cuba/Sociedad/sociedad_los\%20discapacitados\%20en\%20cuba_ tc.htm [06-03-2019].

Mortsiefer, Marius/Pelzer, Kerstin. 2016. "Why Moscow's Most Iconic Church Used to be a Swimming Pool", en: Deutsche Welle, https://www. dw.com/en/why-moscows-most-iconic-church-used-to-be-a-swimmingpool/a-19566508 [13-02-2019].

Oficina nacional de estadísticas. 2012. "Censo de Población y Viviendas 2012", en: http://www.one.cu/informenacional2012.htm [11-10-2018].

Orgado, Samuel. 2012. 'La Piscina: "donde las cosas pueden no suceder", en: Cubacine, http://cubacine.cult.cu/sitios/ficcion/muescoment.php?CM= 053501 [01-10-2018].

Prout, Ryan. 2017. "Within, Against, Inside, Out: Ian Padrón, Fuera de liga, Habanastation, and Music Video", en: Antonio Alvarez Pitaluga/Ann Marie 
Stock/Guy Baron (eds.), Cinema of Cuba: Contemporary Film and the Legacy of Revolution, London: I. B. Tauris: 195-219.

Rodríguez, Yusimí. 2013a. "Este gobierno se preocupa por la gente (II)", en: Havana Times (12 February), https://havanatimesenespanol.org/yusimirodriguez/este-gobierno-se-preocupa-por-la-gente-ii/ [04-03-2019].

Rodríguez, Yusimí. 2013b. "Como [sic] el gobierno de Cuba se preocupa por la gente (3)", en: Havana Times (19 February), https://havanatimesenespanol. org/entrevistas/como-el-gobierno-de-cuba-se-preocupa-por-la-gente-3/ [0403-2019].

Usi, Eva. 2013. "La película cubana La Piscina tuvo su estreno en la Berlinale", en: Deutsche Welle, https://www.dw.com/es/la-pel\%C3\%ADcula-cubana-lapiscina-tuvo-su-estreno-en-la-berlinale/a-16597419 [01-10-2018].

Wiltse, Jeff. 2007. Contested Waters; A Social History of Swimming Pools in America, Chapel Hill: University of North Carolina Press. 



\title{
¿Hacia un séptimo arte inclusivo? El cine brasileño a través del prisma de los disability studies
}

\begin{abstract}
In the last two decades, Brazilian cinema has developed an increasing interest in considering and representing different kinds of disabilities. Taking the example of the award winning film Colegas (2012), directed by Marcelo Galvão and starred by three actors with Down syndrome, this chapter aims to discuss critically the concept of inclusive cinema.
\end{abstract}

Keywords: Brazilian cinema, inclusive cinema, Marcelo Galvão, Down syndrome, disability studies

\section{Introducción}

Desde las últimas dos décadas y, en particular, desde la ratificación brasileña de la Convención sobre los derechos de las personas con discapacidad en 2008 se observa en la industria cinematográfica de Brasil un interés tímido, pero constante y creciente por considerar y representar la discapacidad en sus múltiples y variadas manifestaciones. De la mayor sensibilidad ante el tema dan prueba eventos como el Festival Internacional de Filmes sobre Deficiência "Assim vivemos" ${ }^{\prime}$ y el Festival de Filmes com Accesibilidade Comunicacional do Recife "VerOuvindo", ${ }^{2}$ la publicación en libro y documento audiovisual de la História do Movimento Político das Pessoas com Deficiência no Brasil (2010) por parte de la Secretaria Nacional de Promoção dos Direitos da Pessoa com Deficiência, así como los premios otorgados a producciones como el documental Além da

1 Para más detalle sobre este festival bianual que se inauguró en 2003 y celebró entre agosto y octubre de 2017 su octava edición, véase la página web http://www.assimvivemos.com.br/2017/. Un histórico del festival detallado brinda asimismo el estudio de Bohrer Gilbert 2017: 112.

2 Desde 2014 (este año por quinta vez), el festival recifense exhibe películas nacionales con audiodescripción y en lengua de signos brasileña. Para más información, véase la página web http://verouvindo.com/. 
luz $(2010)^{3}$ que trata la ceguera y A onda traz, o vento leva $(2012)^{4}$ sobre la sordera.

También el colectivo de personas con síndrome de Down (SD), uno de los "símbolos da diversidade" de Brasil (Bohrer Gilbert 2017: 112) a partir del cual el presente estudio examinará el alcance de la inclusión en el séptimo arte del país, ha logrado en estos años una mayor visibilidad. La lucha de los portadores del síndrome y de sus familiares contra la estigmatización y a favor de más autonomía y autodeterminación se plasman, de modo programático, en los títulos de los documentales Do Luto à Luta $(2005)^{5}$ y De arteiro a artista: A saga de um menino com síndrome de Down $(2012)^{6}$ sobre el joven artista plástico Lucio Piantino. A su vez, los documentales Meu olhar diferente sobre as coisas (2013), ${ }^{7}$ Outro olhar (2014) y Outro olhar: Convivendo com a diferença (2015) introducen el leitmotiv de la mirada distinta y distintiva del colectivo en el doble sentido de la fisionomía y del modo de mirar. Por otro lado, dicha mirada alude al cambio de mentalidad en el entorno de los biografiados tanto como a la deseada sensibilización de los espectadores. Pese a las críticas diseminadas, el mensaje de estos documentales es, en suma, alentador para el colectivo y conciliador hacia el público y la sociedad.

3 Dirección y guion: Yves Goulart. El documental fue galardonado en 2010 con el premio especial del jurado popular en el Festival de Cine Brasileño BRAPEQ (Pequín) y con la Palma de Oro en el Mexico International Film Festival (véase la página web http:// www.goulartfilmes.com/pt/tabid/157/Default.aspx).

4 Dirección y guion: Gabriel Mascaro. Una lista de los premios nacionales e internacionales, que este documental ganó, se ofrece en la página web https://pt.gabrielmascaro. com/A-ONDA-TRAZ-O-VENTO-LEVA.

5 Dirección y guion: Evaldo Mocarzel.

6 Dirección y guion: Rodrigo Paglieri.

7 Este documental, dirigido por la directora de la ONG "Me ensina" Gilca Maria Motta da Silveira, es un proyecto llevado a cabo por un colectivo de personas con SD que está tanto delante como detrás de la cámara. En él se rinde, además, tributo a Fernanda Honorato, primera reportera con trisomía 21 en el mundo, que trabaja en el "Programa Especial” orientado hacia las personas con discapacidad de la televisión pública TV Brasil (véase la página web http://tvbrasil.ebc.com.br/programaespecial).

8 La dirección de ambos documentales está a cargo de Renata Sette, quien cuenta con la colaboración de Marcelo A. Machado para los guiones. De corte biográfico, en ellos se retratan, en el primer ejemplo dado, el día a día de la estudiante sur-riograndense Renata Basso y, en el segundo, la vida del sesentón Charbel Gabriel Cury, centrándose, por ende, en el tema de la inclusión de personas con SD en el sistema educativo y en los desafíos de la tercera edad. 
El cine de ficción brasileño parece, a este respecto, más ambiguo e incluso más propenso a representar la exclusión y desintegración en detrimento de la inclusión o integración. Así pues, los cortometrajes Pugile (2007) ${ }^{9}$ y Marina não vai à praia $(2014)^{10}$ visualizan la compleja y difícil relación entre los personajes con trisomía 21 y sus hermanos. Asimismo la adaptación de 2016 del galardonado superventas O filho eterno (2007) de Cristovão Tezza por parte del director Paulo Machline da cuenta de las dificultades de un padre a la hora de reconciliarse con la idea de tener un hijo con SD. ${ }^{11} \mathrm{El}$ impulso inclusivo de estas obras apenas se manifiesta, por ende, en la diégesis y extradiégesis de la película, sino parece reducirse, en gran medida, a la "novelty of foregrounding a protagonist with Down syndrome" (Fraser 2013: 17), es decir, al efecto pedagógico de esta novedad o, dicho de otra manera, al momento catártico de los espectadores que allanará, siguiendo el modelo cultural de los disability studies, el camino hacia una sociedad que reconoce y aprecia su heterogeneidad (cf. Waldschmidt 2005: 27). De lo dicho se deduce, entonces, que la pregunta si Brasil se dirige hacia un

9 Dirección: Danilo Solferini. Guion: Henry Grazinolli y Daniel Solferini. Como lo anticipa el título, Pugile trata del boxeo, verbigracia, de la lucha libre como (único) nexo de unión entre Douglas (Diogo Junqueira), un adulto joven con trisomía 21, y su hermano Edinho (Gustavo Brandão).

10 Dirección y guion: Cássio Pereira dos Santos. El cortometraje premiado trata del deseo de Marina (Aline Videira), una adolescente con SD, de acompañar a su hermana en una excursión escolar hacia el mar.

11 Esta adaptación, realizada por encargo del productor Rodrigo Teixeira y con un guion de Leonardo Levis, merecería un análisis pormenorizado. Vista por más de 30 millones de telespectadores, su elenco cuenta con una excelente Débora Falabella en el papel de la madre (Cláudia) y Marcos Veras como padre (Roberto) -allende del joven Pedro Vinícius (Fabrício)-. Criticada por ser "uma experiência mais light e digerível" (Camargo 2016) que la prosa despiadada de Tezza, la película pulsa, sin embargo, acordes sugerentes para un examen del fenómeno de la inclusión al integrar una estructura temporal novedosa que recuerda la afinidad del director del cortometraje galardonado Uma História de Futebol (1998) con el mundo futbolístico, pero también nuevos personajes como la madre. En la entrevista por escrito realizada por la autora el 14 de octubre de 2018, Paulo Machline subraya el estrecho vínculo entre la creación de este personaje femenino y los desafíos de la integración: "Criamos Cláudia para retratar a figura da mãe e para que as mães se vissem nessa personagem. Durante as pesquisas era muito comum conhecermos famílias, principalmente de renda mais baixa, onde o pai simplesmente não aceitou a criança Down e, geralmente depois de um período de exageros alcóolicos e violência doméstica, abandonou a família. Era recorrente ouvirmos a frase 'a mãe não tem escolha'. Por isso trouxemos essa figura materna com tanta força". 
séptimo arte inclusivo no puede contestarse sin tener en cuenta, allende de la obra fílmica, su producción y recepción. Por su propuesta innovadora y el éxito de crítica y de público, el presente estudio se centrará, a tal fin, en el largometraje Colegas (2012) del productor, director y guionista Marcelo Galvão (1973), ${ }^{12}$ protagonizado por los tres actores con SD Ariel Goldenberg (1980), Rita Pokk (1979) y Breno Viola (1980)..$^{13}$

\section{El cine inclusivo entre inclusión e integración- hacia un marco conceptual}

Un acercamiento conceptual a la inclusión en el medio fílmico arranca casi inevitablemente de una base transdisciplinar. Definiciones brindan, sobre todo, los estudios pedagógicos y sociológicos. De este modo, el pedagogo alemán Georg Theunissen señala que el empoderamiento ${ }^{14}$ la participación ${ }^{15}$ y la inclusión son tres ideas clave $y$, a la vez, complementarias que determinan el discurso educativo desde finales de los años noventa, sustituyendo los principios de normalización

12 Aparte de haber dirigido y escrito el guion de Colegas, Galvão es director y guionista de los largometrajes Quarta B (2005), Lado B: Como Fazer um Longa Sem Grana no Brasil (2007, documental), Bellini e o Demônio (2008), La Riña (2009), A Despedida (2014) y O Matador (2017). Ha ganado numerosos premios nacionales e internacionales en América y Europa. Para más detalles, véase la página web de Gatacine (www. gatacine.com) o el perfil en la base de datos IMDb (https://www.imdb.com/name/ nm2337991/?ref_=nv_sr_1?ref_=nv_sr_1).

13 Para completar este panorama de películas brasileñas con personajes con SD conviene mencionar, además, el largometraje City Down - A história de um diferente (2011. Dirección: José Mattos y Paulo César Nogueira). Esta película (rudimentaria tanto a nivel técnico como a nivel de la trama) experimenta con la idea de un mundo poblado por personajes con trisomía 21 en el cual nace un niño sin diversidad funcional. Para la pequeña pantalla puede hacerse referencia, por último, al personaje de Clara en la telenovela Páginas da vida (2006-2007), interpretada por Joana Mocarzel, hija del director del documental Do Luto à Luta antes mencionado.

14 Este término surgió en los Estados Unidos en un contexto de lucha por la autodeterminación, la participación social y la igualdad ante la ley de personas con diversidad funcional (cf. Theunissen 2010: 14).

15 Theunissen relaciona este concepto con la idea de una participación activa en la vida social y, sobre todo, con el poder y el derecho de decisión de las personas con diversidad funcional (cf. Theunissen 2010: 29-30). Por otra parte, también lo vincula con el proceso de autodeterminación, es decir, con un proceso en el que las personas discapacitadas aprenden a tomar decisiones, a controlar sus acciones y a ser consciente de sí mismo y de su entorno (cf. Theunissen 2010: 30). 
e integración (cf. Theunissen 2010: 13). La inclusión se menciona, por lo tanto, en el mismo contexto como la lucha por la autodeterminación y el derecho de decisión de personas con diversidad funcional. En el sistema educativo, tal inclusión se equipara, entonces, a una escuela para todos, en la que el plan de estudios común se adapta a las necesidades individuales. Medidas inclusivas se dirigen, en este sentido, tanto a personas con y sin diversidad funcional y ayudan, en el mejor de los casos, a abolir las dicotomías y a crear lo que Theunissen llama un espacio social (“Sozialraum”), es decir, una red de contactos compuesta por personas diversas (cf. Theunissen 2010: 20-22, 28).

Desde el punto de vista sociológico adoptado por Jörg Michael Kastl, la inclusión no debe entenderse solo como nuevo paradigma o, en términos críticos, como una utopía social muy difundida actualmente (Kastl 2017: 242), sino también como fenómeno que complementa el modelo de la integración. Partiendo de esta complementariedad, la inclusión se ciñe a la creación de estructuras que facilitan la participación de los individuos en la vida social y, como la otra cara de la moneda, eliminan los obstáculos estructurales que impiden dicha participación. En el ámbito jurídico, tal inclusión se da, por ejemplo, con la ratificación de derechos específicos para personas discapacitadas, en lo arquitectónico, con medidas que permiten la accesibilidad a los espacios públicos, y, en la industria cinematográfica, con proyecciones accesibles a un público discapacitado cognitiva o físicamente, tal y como lo prevén los Festivales "Assim vivemos" y "VerOuvindo" antes mencionados para las personas ciegas y sordas. ${ }^{16}$

Por otra parte, la integración se manifiesta a nivel social cuando personas con $\mathrm{y}$ sin diversidad funcional se relacionan y comparten sus valores y normas, y a nivel sistémico cuando hay una cohesión en un grupo social (cf. Kastl 2017: 234), verbigracia, en una clase, un vecindario o un equipo que interviene en la producción de una película. A diferencia de la inclusión de corte estructural, Kastl sitúa la integración, por lo tanto, en lo social (cf. Kastl 2017: 235). Ahora bien, si se retoma el estudio de Theunissen, se puede observar también en sus líneas una dimensión social que, sin embargo, se incluye terminológicamente en el paradigma de la inclusión con ayuda del concepto de la cultura o identidad inclusiva que comprende "procesos afectivos, comunicativos y sociales, interacciones con personas sin discapacidad (sobre todo, con amigos y conocidos)". ${ }^{17}$

16 Otros ejemplos de inclusión se ofrecen también en el ámbito comunal, laboral, en la vivienda y en el sector cultural (cf. Theunissen 2010: 26).

17 "affektive, kommunikative und soziale Prozesse, Interaktionen mit der nichtbehinderten Bezugswelt (insbesondere Freundschaften und Bekanntschaften)" (Theunissen 2010: 20. La traducción española es de la autora). 
De ahí, no sorprende constatar que, pese a la discrepancia terminológica, ambas investigaciones problematicen la brecha entre la inclusión y la integración o, desde el punto de vista pedagógico, entre las medidas inclusivas realizadas y el deseado resultado de una cultura inclusiva. De este modo, una persona puede estar incluida, pero no integrada (cf. Kastl 2017: 237). Es más, la inclusión puede excluir cuando las ofertas crean espacios paralelos en los que participan (casi) exclusivamente personas discapacitadas (cf. Kastl 2017: 225). A la hora de aplicar el marco conceptual al cine inclusivo ha de tomarse en cuenta, por ende, no solo los distintos momentos de inclusión durante el proceso de producción y de recepción de la película, sino también las tensiones entre lo estructural y lo social que el membrete engloba.

\section{Colegas (2012), de Marcelo Galvão: La fuerza inclusiva de la diversión y el rol de actor}

Colegas relata la historia de Stalone (Ariel Goldenberg), ${ }^{18}$ Aninha (Rita Pokk) y Márcio (Breno Viola), tres amigos con SD que deciden escapar, tras haber asistido a la road movie estadounidense Thelma \& Louise (1991), del internado donde viven para ir en busca de sus sueños: Stalone desea ver el mar, Márcio quiere volar y Aninha, casarse. Lo que empieza, sin embargo, como una simple escapada se transforma pronto en una doble persecución tanto policial como mediática, puesto que los adolescentes, disfrazados con llamativas máscaras sacadas de I clowns (1970) de Federico Fellini, van robando comida y ropa a lo largo de su viaje del sur de Brasil a Buenos Aires.

El personaje Márcio lleva el nombre de un difunto tío, portador del SD, de Galvão. Este vínculo personal del director carioca con la temática que aborda en su cuarto largometraje de ficción explica también la dedicatoria en la que le agradece al familiar "por ter me ensinado tanto" (cf. 1:32:02; cf. también Movimento Down 2013a; Campos Mello 2016). El homenaje a su difunto tío no pretende ser, sin embargo, una película sobre el SD, sino una obra en la cual actúan portadores del síndrome: ${ }^{19}$

18 Del nombre de este personaje existen dos ortografías: Hay quienes optan por la variante Stallone, de acuerdo con el nombre de Sylvester Stallone, el ídolo del padre del personaje. En este estudio se sigue, empero, la forma Stalone, tal y como figura en los créditos de la película (cf. 1:32:33).

19 Esta posición parece, sobre todo, estratégica. Es cierto que la película se inscribe en el género de la road movie y en el cine policíaco por lo que permite varias lecturas. Pero no puede pasarse por alto que el hecho de que los protagonistas tienen SD motiva los sueños y fundamenta la reflexión acerca de lo normativo en Colegas. 
O nosso filme tem três protagonistas especiais e 60 garotos com síndrome de Down no elenco, mas não é sobre Down. É uma história divertida sobre temas como superação e amizade. Não queremos dar nenhuma lição, mas divertir as pessoas. Essa é a verdadeira inclusão. (Movimento Down 2013b)

Cuando Galvão sugiere que la inclusión no se dirige ni se centra únicamente en las personas con discapacidad, coincide con el concepto del espacio social, acuñado por Theunissen (cf. Theunissen 2010: 20-22). La diversión, así podría resumirse la idea del director, configura un espacio común compuesto por los espectadores con y sin diversidad funcional o, en otras palabras, una "community of laughter" (Schwanebeck 2015: 103) ${ }^{20}$ capaz de eludir, por momentos, la seriedad de la lucha política y el efecto -a menudo excluyente- de un mensaje aleccionador y moral. Aun cuando la volatilidad de tal comunidad imposibilita medir su alcance real, el éxito de público de Colegas -una road movie dirigida a adultos y a adolescentes, con una estructura y un argumento simple y reconocible - admite inferir la fuerza integradora así determinada. Otro tanto permite el éxito de crítica: Tras haber vencido en 2008 el Festival Paulínia de Cine en la categoría de mejor guion, la obra ganó el llamado kikito del Festival de Gramado de 2012 y una serie de premios nacionales e internacionales, entre los cuales figuran el de público en la $36^{a}$ Muestra Internacional de Cinema de São Paulo, el premio Caneskov a mejor película en el International Disability Festival de Moscú, el Lente de Cristal en el Brazilian Film Festival of New York y otros similares en festivales en Chile, Italia, Portugal y Canadá (cf., entre otros, Luiz 2012; Almeida 2013). De hecho, este éxito sigue dando frutos: Según comentó el joven director en una entrevista de audio realizada por la autora el 23 de octubre de 2018, se encontraba en ese momento en Los Ángeles para negociar las condiciones de un remake norteamericano. Para 2019 anunció, además, el rodaje de Colegas 2, a missão, una continuación coproducida por Globo Filmes (cf. Revista Preview 2018).

El impulso inclusivo e integrador no se limita, sin embargo, a la recepción exitosa de la película, sino ha de buscarse asimismo en la promoción de los actores con SD. Si bien es cierto que el proyecto fílmico ganó en visibilidad gracias a la captación en papeles secundarios de actores de la talla del veterano Lima Duarte o de la más joven Juliane Didone y de estrellas de televisión como el cómico Marco Luque y el presentador Otávio Mesquita, convienen valorarse asimismo

20 El concepto popularizado por Werner Röcke y Hans Rudolf Velten resalta la fuerza de cohesión de la risa, aun cuando la risa puede ser excluyente (cf. Schwanebeck 2015: 103-104). 
los impulsos - hasta la fecha inéditos en Brasil- realizados en beneficio de la profesionalización de los actores discapacitados. A este respecto, la directora de comunicación Aleksandra Zakartchouk cuenta en el blog Colegas, o filme que la productora Gatacine, localizada en São Paulo y fundada por Galvão en 2001, creó al hilo de los cástines un banco de datos con actores con trisomía 21 (cf. Zakartchouk). ${ }^{21}$ De la manera más evidente, este empoderamiento del rol de actores (semi)profesionales se percibe, sin embargo, en los paulistas Goldenberg y Pokk y en el carioca Viola, el primer judoka con SD y cinturón negro de las Américas que se sumó al elenco de protagonistas en 2010 (cf. Zakartchouk). Por un lado, se tiene constancia de que los cónyuges Goldenberg y Pokk, que ya aparecen en el documental Do luto à luta, ${ }^{22}$ recibieron una preparación continua en la productora para mejorar sus dotes de actor y acostumbrarse al equipo (cf. Zakartchouk). Por otro lado, Goldenberg, Pokk y Viola participaron también en la campaña televisiva. Son memorables los quince minutos en "TV Xuxa" (Rede Globo, 17-03-2012) para captar fondos para la película (cf. TV Xuxa 2012), la cual-debido, según el director, a los reparos de las empresas a la hora de vincular su marca con personas discapacitadas- seguía inédita. Digno de mención son, además, las entrevistas tras haber ganado el kikito, a saber, la de Danilo Gentili en el programa de noche "Agora é tarde" (Rede Bandeirantes, 21-08-2012) y la de Ana Maria Braga en su programa "Mais você" (Rede Globo, 23-08-2012). A estas presencias se suman la charla de Viola ante la ONU el Día Mundial del Síndrome de Down de 2013, y la proyección de la película en julio del mismo año en la VI Conferencia de Estados Partes de la Convención sobre los derechos de personas con discapacidad (cf. Almeida 2013).

Ahora bien, esta visibilidad tanto nacional como internacional se debe, en gran medida, a la campaña \#vemseanpenn lanzada el 6 de febrero de 2013, es decir, tres semanas antes del estreno de Colegas: En un corto vídeo, una voz superpuesta cuenta la vida de Goldenberg, quien aparece, finalmente, secundado por varias personalidades brasileñas para invitar a la estrella de cine estadounidense Sean Penn al estreno nacional del 1 de marzo. No se aspira aquí a aportar respuestas conclusivas a la pregunta si se trata de un truco publicitario -de

21 En el blog señalado se encuentra material abundante sobre el desarrollo del proyecto fílmico desde sus inicios en julio de 2008 hasta la última entrada en noviembre de 2013, en la cual se da cuenta del premio a mejor actor para Goldenberg y el de mejor director para Galvão en el Brazilian Film \& TV Festival of Toronto (cf. Zakartchouk).

22 Goldenberg actúa, además, en el cortometraje Oujia (2009) de Galvão y en episodios de la serie Carga pesada (Rede Globo) y de la telenovela Jamais te esquecerei (SBT) (cf. Capriglione 2013). 
hecho, Galvão tiene formación en publicidad (cf. Bridi 2014)- o realmente de una iniciativa de Goldenberg, cuyo soporte en la financiación de la película se calcula en medio millón de reales en patrocinios y donativos, conforme reveló el director a la autora. Lo cierto es que el vídeo, que cuenta en la actualidad con más de 1.6 millones de visualizaciones en Youtube (cf. ColegasOFilme 2013), se convirtió en viral y, a pocos días, se sumaron al coro que pedía "vem, Sean Penn" los jugadores del Santos Futebol Clube, entre ellos, Neymar (cf. Santos Futebol Clube 2013). Este episodio anecdótico, que termina con la fama repentina del proyecto fílmico ${ }^{23}$ y con un encuentro de Goldenberg y Pokk con el ídolo en Los Ángeles (cf. Movimento Down 2013c), plantea, sin duda, la pregunta acerca del alcance de la inclusión en dicho contexto. Formular ciertos reparos ético-morales a tamaña exhibición de los actores con SD es legítimo. De la misma forma, puede alegarse, sin embargo, que si la inclusión comprende el ejercicio de diversos roles sociales (cf. Kastl 2017: 228-232), entonces la participación de los protagonistas en la campaña y, en particular, la información brindada acerca de su trabajo supone una conquista del rol de actor. Cuando Lennard J. Davis lamenta que, por lo general, "only non-disabled characters can become stars" y critica que "[t]his state of affairs also ghettoizes stardom" (Davis 2017: 49), el ejemplo de Colegas constituye, en este sentido, la feliz -y, tal vez, única- excepción que confirma la regla.

\section{Colegas (2012), de Marcelo Galvão: Entre transgresión y ambivalencia}

En lo que a la trama de la película se refiere, llama la atención que -por lo menos, a primera vista- no trata de inclusión. Por el contrario, refleja una diferenciación y consiguiente desintegración social que coincide con un pasado latinoamericano en el que personas discapacitadas fueron "drastically marginalized, remaining isolated and hidden from view in the family home or [como en el caso de Colegas] relegated to institutions" (Antebi/Jörgensen 2016: 3). En sintonía con esta realidad pretérita, ${ }^{24}$ los tres protagonistas no están solos -tienen a sus

23 Zakartchouk relata ese momento clave en su blog: "Depois veio o vídeo Vem Sean Penn e a vida da gente virou uma loucura. O telefone tocava sem parar. A caixa de emails [sic] vivia lotada. Eram dezenas e dezenas de pedidos de entrevistas. Quando esse tsunami mal tinha passado, veio a onda gigante da estreia do filme nos cinemas. [...] Em poucos dias, nossa página no Facebook saltou de 5 mil seguidores para 156 mil (hoje temos mais de 238 mil seguidores)" (Zakartchouk).

24 En cuanto al marco temporal, se observa cierto anacronismo. Mientras que el estilo retro del decorado parece situar la trama en los años noventa, las referencias a películas 
colegas-, pero sí viven aislados de la sociedad y dependientes de instructores en un instituto de educación especial. En el fondo, la película traza tres historias de abandono familiar, en las que los sueños antes señalados evidencian una carencia apenas disimulada por el tono tragicómico de una voz narrativa: Stalone quiere aprender a nadar para poder visitar a su madre, quien dice vivir en Atlántida; Márcio, cuyos padres fallecieron siendo él joven, desea volar para poder construir la casa en la luna de sus hermanas. Y, por último, Aninha anhela casarse porque sus padres le prometieron venir a visitarla el día que se despose con un artista: el día de San Judas Tadeo, es decir, el día del santo de las causas imposibles (13:57-14:43). Al hilo del viaje se va revelando, además, que la desintegración se explaya a toda la sociedad. Con excepción de niños y animales, de algún u otro personaje caritativo y del microcosmos cerrado del internado, la sociedad los rechaza menos con gestos abiertamente violentos que con términos ofensivos como "vagabundos" (15:46), "problemáticos" (16:02), "retardado" (39:40), "deficientes mentais" (50:53), "mongoloides" (1:27:15) o tachándoles implícitamente de caníbales (36:21).

No obstante, la película evita el discurso victimista, diluyendo al máximo la dicotomía entre agresor y agredido y quebrantando la asimetría de poder inherente a la estigmatización de la discapacidad (cf. Hartwig 2018: 2018). Con ello, Galvão logra eludir, en partes, una representación paternalista en la que "either a person is deemed sufficiently disabled so as to have earned the viewer's pity or, on the flipside, the person seems to have transcended his or her disability so as to have earned the viewer's respect" (Fraser 2013: 5, cf. también Davis 2017: 39). De hecho, los personajes con SD confirman y, a la vez, exageran los estereotipos impuestos por la sociedad. No solo las historias descabelladas de los alumnos interrogados por la policía en una escena que roza lo grotesco (17:23-19:14), sino también los disfraces de genio de la lámpara, princesa y hombre bala que lucen los tres protagonistas durante su fuga afianzan la idea del mundo lúdico e imaginativo, es decir, fuera de la norma y de lo normal, que habitan. Asimismo, el invitado especial de un talk show - un niño con trisomía 21- reafirma con un bramido en primer plano el peligro que emana de su ser deficiente, a medio camino entre lo humano y lo animal (51:08-51:35). Y, como colofón, los protagonistas se convierten en delincuentes, robando chuches, además de una revista pornográfica que parece afianzar, implícitamente, el estereotipo de la hipersexualidad de personas discapacitadas (cf. Silva/Calsa 2017).

más recientes como Tropa de élite (2007), supuestamente vistas por los protagonistas durante su trabajo en la videoteca, la ubica en un pasado más reciente. 
Ahora bien, la fuerza transgresora de la película parece residir justamente en el carácter hiperbólico y humorístico de esta anormalidad. De nuevo, Colegas puede leerse, por lo tanto, como un intento de abolir las distancias entre las personas con y sin diversidad funcional a través del humor (cf. Hartwig 2016: 239) y de conformar, por esta vía, una comunidad inclusiva; una comunidad que no solo comprende al público diverso, sino también integra a los personajes con SD dentro de la película. Gracias a un sutil juego autorreferencial, los espectadores se ven, pues, reflejados en los alumnos del internado que siguen el viaje de sus compañeros a través de la televisión: las risas de los alumnos a nivel intradiegético (36:24-36:29; 47:35-48:02) duplican y refuerzan, de este modo, las risas de los espectadores a nivel extrafílmico. Por otra parte, la sexualidad referida por último -que es, junto con la integración laboral, uno de los temas más debatidos en los documentales brasileños sobre el $\mathrm{SD}^{25} \mathrm{y}$, a la vez, uno de los aspectos más sujetos a tabúes- pone de relieve una transgresión en el proyecto fílmico de Galvão que prescinde del humor. Así pues, Ariel y Aninha se casan durante el viaje $y$, tras protegerse de la lluvia en un camión que los llevará a Buenos Aires, disfrutan de una noche de bodas cargada de erotismo (1:10:34-1:11:24). Tal vez desconcertante desde una perspectiva de género, el deseo de Aninha de casarse se transforma, en fin, en el deseo más transgresor gracias al empoderamiento doble del rol social como esposa y del rol profesional como actriz que supone.

Aparte de estas transgresiones, es necesario señalar asimismo las ambivalencias que la película mantiene. De ejemplo sirven, en primer lugar, las máscaras que los protagonistas llevan durante los asaltos y que esconden, momentáneamente, sus rasgos físicos. Más que distraer de la diversidad funcional, este juego de simultánea visibilidad e invisibilidad acentúa, empero, los distintos fenotipos -en sintonía con el núcleo narrativo "da corporeidade" que realza las marcas somáticas, llevando a la "valorização" y al "reconhecimento dos limites e contornos da SD" (Bohrer Gilbert 2017: 114)-. Se puede sostener, por lo tanto, que las máscaras impulsan la reflexión sobre lo normativo; una reflexión que se ve secundada por la "anormalidad" del mundo "normal", tal y como se manifiesta en la estupidez de los agentes Souza y Ferrari y en la discapacidad física del agente Fonseca, a quien solo le queda el dedo del corazón en la mano izquierda $(1: 05: 42)$.

25 La importancia del amor y, sobre todo, del trabajo se subraya también en el estudio de Fraser: "Achieving full social integration requires allowing persons with disabilities the opportunity to engage in meaningful work" (Fraser 2013: 13). Con respecto a la película es interesante constatar que se sabe muy poco del trabajo de los tres en la videoteca del colegio. 
En segundo lugar, esta ambivalencia se refuerza mediante las réplicas. De hecho, los tres protagonistas se expresan frecuentemente con ayuda de citas sacadas de películas clásicas a las que habían asistido en la videoteca del instituto donde trabajaban. "Everybody be cool, this is a robbery!" (1:52-1:55), gruñe Stalone con referencia a Pulp fiction (1994) de Quentin Tarantino cuando entra en el primer establecimiento. Y se despide con un "hasta la vista, baby" (2:502:52), inspirado en Terminator 2: el juicio final (1991) de James Cameron. ${ }^{26}$ En un principio, este recurso se ideó por una cuestión meramente práctica, conforme explica Galvão en la entrevista de octubre de 2018: No se percibirían tanto las sobreactuaciones de Goldenberg, Pokk y Viola. Para Colegas, sin embargo, estas referencias constantes plantean dudas serias acerca del alcance de la voz propia de los personajes con trisomía 21. Tales dudas se confirman al tomar en cuenta la voz narrativa del jardinero Seu Arlindo (Lima Duarte), criticada reiteradas veces (cf. Bahiense 2013; Bridi 2014). En el fondo, este personaje, al comentar la vida y el viaje de Stalone, Aninha y Márcio, reimplanta una visión paternalista a la que Colegas parecía haberse sustraído exitosamente mediante el humor.

Por último, vale la pena referirse, de modo crítico, al final de la película que ilustra cómo los tres amigos vuelven al internado escoltados por la policía. Si bien es cierto que los protagonistas han logrado apoderarse del papel clásico del delincuente, la impunidad final y la absolución por parte del público -el cual no puede sino sentir simpatía por estos colegas- atenúa la fuerza transgresora de este empoderamiento y vuelve a colocarlos, finalmente, en la situación inicial de exclusión social y de dependencia. Al mismo tiempo, este final que parece tan sobrio evita con éxito la muy difundida narrativa de superación y, con ello, también la "idealização de inclusão que significaria uma diluição da diferença" (cf. Bohrer Gilbert 2017: 116-117).

\section{A modo de conclusión}

El membrete del cine inclusivo no deja de ser lo que es: Un membrete que llama la atención sobre una industria que intenta, de distintas maneras, dar la bienvenida a personas con discapacidad. La definición propuesta para este estudio da cuenta, sin embargo, de la complejidad de un nuevo paradigma cultural que, si se traduce al séptimo arte, engloba no solo la producción, el producto fílmico y

26 En los créditos de la película se revelan, además, referencias fílmicas a El club de los poetas muertos (1989), El silencio de los corderos (1991), Perros de reserva (1992), Forrest Gump (1994), Titanic (1997), La vida es bella (1997), Matrix (1999), Cidade de Deus (2002) o Tropa de élite (2007), entre otras. 
la recepción, sino también las tensiones entre la dimensión estructural y social inherente al término. No existen, por consiguiente, respuestas unívocas y conclusivas a la pregunta planteada si el cine brasileño se dirige hacia un séptimo arte inclusivo. La realidad de exclusión social y de dependencia representada en la película Colegas, además de cierto paternalismo insistente en la forma, apuntan en dirección opuesta. Por otra parte, la preparación de los actores con síndrome de Down, una campaña publicitaria sin precedentes y el recurso al humor no dejan lugar a dudas que el cine brasileño es capaz de poner en tela de juicio ciertos discursos normativos y de promover un espacio de empoderamiento y de diversión en el que personajes, actores y espectadores convergen.

\section{Filmografía}

Galvão, Marcelo. 2012. Colegas, Brasil: Gatacine.

Goulart, Yves. 2010. Além da luz, Brasil: Goulart Filmes.

Machline, Paulo. 2016. O filho eterno, Brasil: RT Features/Camisa Treze Produções Artísticas/Globo Filmes.

Mascaro, Gabriel. 2012. A onda traz, o vento leva, Brasil/España: Desvia/Art Aids.

Mattos, José/Nogueira, Paulo César. 2011. City Down - A história de um diferente, Brasil: Vinny Filmes.

Mocarzel, Evaldo. 2005. Do Luto à Luta, Brasil: Casa Azul Produções Artísticas/ Circuito Espaço de Cinema.

Motta da Silveira, Gilca Maria. 2013. "Meu olhar diferente sobre as coisas", en: http://www.meensina.org.br/site/2016/02/assista-o-documentario-meuolhar-diferente-sobre-as-coisas/ [30-04-2019].

Paglieri, Rodrigo. 2012. "De arteiro a artista: A saga de um menino com síndrome de Down", en: https://www.youtube.com/watch?v=E3kdnGkZNWs [30-04-2019].

Pereira dos Santos, Cássio. 2014. Marina não vai à Praia, Brasil: Padéia Filmes/ Trotoar Filmes.

Secretaria Nacional de Promoção dos Direitos da Pessoa com Deficiência. 2010. "História do Movimento Político das Pessoas com Deficiência no Brasil", en: https://www.pessoacomdeficiencia.gov.br/app/publicacoes/historia-domovimento-politico-das-pessoas-com-deficiencia-no-brasil [30-04-2019].

Sette, Renata. 2014. Outro olhar, Brasil: Maria Farinha Filmes.

Sette, Renata. 2015. Outro olhar: Convivendo com a diferença, Brasil: Maria Farinha Filmes.

Solferini, Danilo. 2007. Pugile, Brasil: Vermelho Filmes. 


\section{Bibliografia}

Almeida, Patrícia. 2013. "Filme Colegas será exibido na ONU", en: http:// www.movimentodown.org.br/2013/07/filme-colegas-sera-exibido-na-onu/ [24-09-2018].

Antebi, Susan/Jörgensen, Beth E. 2016. "Introduction: A Latin American Context for Disability Studies”, en: Susan Antebi/Beth E. Jörgensen (eds.), Libre Acceso. Latin American Literature and Film through Disability Studies, Albany: State University of New York Press: 1-26.

Bahiense, Sandro. 2013. “Crítica do filme Colegas", en: http://outros300.blogspot. com/2013/03/critica-do-filme-colegas.html [22-11-2018].

Bohrer Gilbert, Ana Cristina. 2017. "Narrativas sobre síndrome de Down no Festival Internacional de Filmes sobre Deficiência Assim Vivemos", en: Interface 21 (60): 111-121.

Bridi, Natália. 2014. “Colegas: Crítica. Fábula de Marcelo Galvão vai além da síndrome de Down”, en: https://www.omelete.com.br/filmes/criticas/colegascritica [30-04-2019].

Camargo, Paulo. 2016. “O Filho Eterno atenua a obra de Tezza”, en: http://www. aescotilha.com.br/cinema-tv/central-de-cinema/o-filho-eterno-atenua-obrade-tezza/ [30-04-2019].

Campos Mello, Raphaela de. 2016. "Uma entrevista com o Marcelo Galvão, diretor do filme Colegas", en: https://casa.abril.com.br/profissionais/umaentrevista-com-o-marcelo-galvao-diretor-do-filme-colegas/ [22-11-2018].

Capriglione, Laura. 2013. “'Sou igual a todo mundo', diz o ator Ariel Goldenberg, que tem Down", en: http://ciateatralolhosdedentro.com.br/cinema/sou-iguala-todo-mundo-diz-o-ator-ariel-goldenberg-que-tem-down/ [30-04-2019].

ColegasOFilme. 2013. "\#VemSeanPenn", en: https://www.youtube.com/ watch?v=bHNTPdy0CIM [30-04-2019].

Davis, Lennard J. 2017. “The Ghettoization of Disability: Paradoxes of Visibility and Invisibility in Cinema", en: Anne Waldschmidt/Hanjo Berressem/Moritz Ingwersen (eds.), Culture - Theory - Disability. Encounters between Disability Studies and Cultural Studies, Bielefeld: Transcript: 39-49.

Fraser, Benjamin. 2013. "Filming Down Syndrome”, en: Benjamin Fraser (ed.), Disability Studies and Spanish Culture. Films, Novels, the Comic and the Public Exhibition, Liverpool: Liverpool University Press: 1-33.

Hartwig, Susanne. 2016. "Andere Geschichten über geistige Behinderung? Die Spielfilme Le huitième jour (1996), Yo, también (2009) und Léon y Olvido (2004)", en: Germanisch-Romanische Monatsschrift 66 (2): 225-240. 
Hartwig, Susanne. 2018. "Introducción: representar la diversidad funcional", en: Julio Checa/Susanne Hartwig (eds.), ¿Discapacidad? Literatura, teatro y cine hispánicos vistos desde los disability studies, Frankfurt a. M. et al.: Peter Lang: 7-21.

Kastl, Jörg Michael. 2017. Einführung in die Soziologie der Behinderung, 2a ed. revisada y ampliada, Wiesbaden: VS.

Luiz, Márcio. 2012. "Colegas ganha o Kikito de melhor filme no Festival de Gramado”, en: http://g1.globo.com/rs/rio-grande-do-sul/noticia/2012/08/ colegas-ganha-o-kikito-de-melhor-filme-no-festival-de-gramado.html [2309-2018].

Movimento Down. 2013a. "Colegas vence prêmio de melhor filme no Festival de Gramado”, en: http://www.movimentodown.org.br/2013/01/colegas-vencepremio-de-melhor-filme-no-festival-de-gramado/ [23-09-2018].

Movimento Down. 2013b. “Colegas emociona o público em pré-estreia no Rio de Janeiro”, en: http://www.movimentodown.org.br/2013/01/colegas-emocionao-publico-em-pre-estreia-no-rio-de-janeiro/ [23-09-2018].

Movimento Down. 2013c. "Colegas vence festival de cinema brasileiro em Nova York”, en: http://www.movimentodown.org.br/2013/06/colegas-vencefestival-de-cinema-brasileiro-em-nova-york/ [24-09-2018].

Revista Preview. 2018. "Produção de Colegas 2 abre casting para atores Down", en: http://revistapreview.com.br/especiais/producao-de-colegas-2-abrecasting-para-atores-down/ [22-11-2018].

Santos Futebol Clube. 2013. “\#VemSeanPenn - O Santos FC quer ajudar a realizar o sonho do Ariel!”, en: https://www.youtube.com/watch?v=hCfqm6NggVY [30-04-2019].

Schwanebeck, Wieland. 2015. "The More, the Merrier? British Comedy and the Community of Laughter", en: Anglistik: International Journal of English Studies 26 (1): 103-113.

Silva, Elaine da/Calsa, Geiva Carolina. 2017. "Síndrome de Down, sexualidade e preconceito no filme Colegas", en: http://www.sies.uem.br/ trabalhos/2017/3196.pdf [25-04-2019].

Tezza, Cristovão. 2007. O filho eterno, Lisboa: Gradiva.

Theunissen, Georg. 2010. "Inklusion - Schlagwort oder zukunftsweisende Perspektive?", en: Georg Theunissen/Kerstin Schirbort (eds.), Inklusion von Menschen mit geistiger Behinderung: Zeitgemäße Wohnformen - Soziale Netze - Unterstützungsangebote, $2^{\mathrm{a}}$ ed., Stuttgart: Kohlhammer: 13-40.

TV Xuxa. 2012. "Xuxa conversa com o elenco de Colegas - O Filme”, en: http:// gshow.globo.com/programas/tv-xuxa/videos/v/xuxa-conversa-com-oelenco-de-colegas-o-filme/1861514/ [30-04-2019]. 
Waldschmidt, Anne. 2005. "Disability Studies: Individuelles, soziales und/oder kulturelles Modell von Behinderung", en: Psychologie und Gesellschaftskritik 29 (1): 9-31.

Zakartchouk, Aleksandra. s.a. "Colegas - O filme. O diário a bordo da produção", en: https://blogcolegasofilme.com/ [30-04-2019]. 


\section{Sobre los autores}

Susan Antebi. Doctora en Lenguas y Literaturas Románicas por Harvard University. Desde el año 2009, profesora asociada de Literatura Latinoamericana en la Universidad de Toronto. Líneas de investigación: literatura y producción cultural latinoamericana y mexicana, siglos XX-XXI, disability studies. Publicaciones recientes: con Beth Jörgensen, (eds.), Libre Acceso: Latin American Literature and Film through Disability Studies (2016); con David Mitchell y Sharon Snyder, (eds.), The Matter of Disability: Materiality, Biopolitics, Crip Affect (2019).

Alejandra M. Aventín Fontana. Licenciada en Filología Hispánica por la Universidad Autónoma de Madrid, Diplomada por University of Kent at Canterbury en Cultura Hispánica y Máster en Enseñanza del Español como Lengua Extranjera por la Universidad Antonio de Nebrija. Se doctoró en la Universidad Autónoma de Madrid dentro del Programa de Doctorado en Las Literaturas Hispánicas y Los Géneros Literarios en el Contexto Occidental. Es desde el año 2010, profesora e investigadora en la Universidad Carlos III de Madrid -en la actualidad es Profesora Visitante y Secretaria Académica del Departamento de Humanidades: Filosofía, Lenguaje y Literatura-. Desde el año 2010 es asesora para la candidatura de Patrimonio Nacional del Premio Reina Sofía de Poesía Iberoamericana. Líneas de investigación: la poesía hispánica contemporánea, el feminismo y los estudios de género, el exilio hispánico, la memoria histórica, la representación del cuerpo, la ecocrítica y las relaciones de poder. Publicaciones recientes: (ed.), Ana Istarú, Nido entre la grieta. Antología poética (2013); "Cósmica quietud: apuntes para una lectura ecocrítica de la poesía de Laureano Albán”, en Boletín Millares Carló (2017); (ed.), El bosque de los símbolos. Corporeidad y analogía en la poesía hispánica contemporánea (2018).

Patricia Brogna. Doctora en Ciencias Políticas y Sociales y Maestra en Estudios Políticos y Sociales, UNAM, México. Maestra en Integración de Personas con Discapacidad, Universidad de Salamanca, España. Profesora Asociada a Tiempo Completo en la Facultad de Ciencias Políticas y Sociales, UNAM. Investigadora y Coordinadora del Seminario Permanente sobre discapacidad del Programa Universitario de Derechos Humanos, de la UNAM. Estancias académicas en España. Docente en Argentina, Colombia y Chile. Líneas de investigación: perspectivas decoloniales; estudios sobre los procesos de discapacitación con aportes desde la negritud y la teoría feminista; otredad, exclusión social; derechos humanos y políticas públicas. Publicaciones recientes: "Discapacidad en la cosmovisión 
nahua, la representación de un cuerpo múltiple", en Pasajes 6 (Enero-Junio 2018); (coord.), Marco de referencia y propuesta metodológica para la evaluación de la atención educativa a estudiantes con discapacidad (2019); co-coordinadora de la colección Voces de la alteridad, FESI-UNAM.

Berit Callsen. Licenciada en Filología Románica por la Humboldt-Universität zu Berlin. Tesis de doctorado sobre la representación de la percepción visual en la literatura mexicana y francesa de la segunda mitad del siglo XX. Proyecto de habilitación sobre culturas del sujeto en la modernidad española. Docente e investigadora en Würzburg y Hannover. Desde 2017 profesora universitaria de Ciencias Culturales Románicas en la Universität Osnabrück. Líneas de investigación: la visualidad literaria en una perspectiva interdisciplinar, corporalidades en la literatura latinoamericana reciente, constituciones del sujeto en la literatura y cultura españolas de fin de siglo. Publicaciones recientes: Mit anderen Augen sehen. Aisthetische Poetiken in der französischen und mexikanischen Literatur (1963-1984) (2014); con Sandra Hettmann y Yolanda Melgar Pernías (eds.), Bilder-Texte-Bewegungen. Interdisziplinäre Perspektiven auf Visualität (2016).

Julio E. Checa Puerta. Doctor en Filología Hispánica por la Universidad Complutense de Madrid, con una tesis titulada Los teatros de Gregorio Martínez Sierra (Fundación Universitaria Española, 1998), dirigida por María Francisca Vilches de Frutos, por la que obtuvo el Premio Extraordinario de Doctorado en Filología. Profesor Titular de Literatura Española y Decano de la Facultad de Humanidades, Comunicación y Documentación de la Universidad Carlos III de Madrid. Miembro del grupo InGenArte (CSIC), y de la red transversal de Estudios de Género en Ciencias Humanas, Sociales y Jurídicas (GENET), desde el año 2007. Premio de Investigación, junto con Eduardo Pérez-Rasilla, "Leandro Fernández de Moratín 2006", concedido por la ADE. Profesor visitante en las universidades Justus Liebig de Giessen (Alemania), Wesleyan (EE.UU.), y Toulouse le Mirail (Francia). Codirige, junto a Susanne Hartwig, la colección de estudios sobre "Images of Disability. Literature, Scenic, Visual, and Virtual Arts/Imágenes de la diversidad funcional. Literatura, artes escénicas, visuales y virtuales", editada por Peter Lang (Alemania). Líneas de investigación: la Representación de la Diversidad en la Literatura española y en las Artes Escénicas en el ámbito hispánico, las Imágenes de Género en la Literatura española y en las Artes Escénicas en el ámbito hispánico de los siglos XX y XXI, así como la Historia, Teoría y Crítica de la Literatura española escrita por autoras y del Teatro español de los siglos XX y XXI. Publicaciones recientes: "Siglo mío; bestia mía, de Lola Blasco: Diario, testimonio y confesión”, en Estreno (2017); “Conciertos de despedida: dramaturgas 
españolas frente al exilio juvenil” (2018); con Susanne Hartwig (eds.), ¿Discapacidad? Literatura, teatro y cine hispánicos vistos desde los disability studies (2018).

Alejandro Gasel. Profesor regular del área Metodología Literaria en la Universidad Nacional de la Patagonia Austral (Río Gallegos, Argentina). Obtuvo su Doctorado en Letras por la Universidad Nacional de La Plata (Buenos Aires, Argentina) con una tesis sobre la Patagonia Austral en la narrativa argentina reciente. Ha publicado en revistas de su especialidad. Asimismo, enseña Lengua, Literatura en el Profesorado de Educación Especial orientado (sujetos discapacidad sordos-trastornos del lenguaje/discapacidad intelectual) dependiente del IPES Río Gallegos.

Susanne Hartwig. Licenciada en Filología Románica y Latina por la Universität Münster (Alemania). Tesis sobre el teatro francés después de 1945, habilitación sobre el teatro español contemporáneo. Docente e investigadora en Münster, París, Madrid, Gießen, Potsdam, Erfurt, San José de Costa Rica y Curitiba. Desde el año 2006, catedrática de Literaturas y Culturas Románicas en Passau (Alemania). Líneas de investigación: literatura y ética (dilema y diversidad), diversidad funcional (Images of disability), teatro y cine contemporáneo, narrativa contemporánea en América Latina, literatura y ciencia cognitiva. Publicaciones recientes: (ed.), Ser y deber ser. Dilemas morales y conflictos éticos del siglo XX vistos a través de la ficción (2017); (ed.), Diversidad Diversidad cultural - ficcional - ¿moral? (2018); con Julio Checa (eds.), ¿Discapacidad? Literatura, teatro $y$ cine hispánicos vistos desde los disability studies (2018), primer volumen de la colección "Images of Disability. Literature, Scenic, Visual, and Virtual Arts/Imágenes de la diversidad funcional. Literatura, artes escénicas, visuales y virtuales" (Open Access).

Adrián Herrera-Fuentes. Doctor en filología románica. Tesis comparatista sobre literatura alemana de viajes en México durante el nacionalsocialismo. Se ha desempeñado como docente en la Universidad de Bonn (Alemania), así como docente invitado en la Escuela Nacional de Antropología e Historia (México), Macalester College (Saint Paul, MN) y California State University at Long Beach (Long Beach, EE.UU.). Desde junio de 2018, docente de planta en el Seminario de Lenguas Romances de la Universidad de Colonia. Actualmente trabaja en una habilitación sobre poliglosia en literatura de viajes en lengua francesa (Montaigne, Humboldt y Voltaire). Líneas de investigación: literatura de viajes francesa y alemana (Alexander von Humboldt, Michel de Montaigne), novela mexicana contemporánea, cuentística francesa del siglo XVIII (Voltaire), cine 
y cultura visual contemporáneas, novela española moderna y contemporánea, novelística francesa (1900-1950), estudios de género y del cuerpo.

Beth E. Jörgensen. Doctora en Letras Hispanoamericanas por la Universidad de Wisconsin-Madison. Catedrática Emérita de Literatura Hispanoamericana, Universidad de Rochester (NY, EE.UU.). Líneas de investigación: ficción, crónica y autobiografía mexicanas contemporáneas; escritoras mexicanas; estudios de la discapacidad. Publicaciones recientes: Documents in Crisis: Nonfiction Literatures in 20th-Century Mexico (2011); con Susan Antebi (eds.), Libre Acceso: Latin American Literature and Film through Disability Studies (2016).

Mirjam Leuzinger. Máster en Filología Hispánica y Francesa y Ciencias del Deporte (Berna). Doctora con una tesis sobre Jorge Semprún (Berna). Becaria del Fonds national suisse. Estancias en Madrid, París, Praga y Curitiba. Desde 2014, profesora en la Universidad de Passau. Líneas de investigación: ensayo y narrativa hispánica y francesa (siglos XX-XXI), cine brasileño, memoria y discursos sobre Europa. Publicaciones recientes: Jorge Semprún: Memoria cultural y escritura. Vida virtual y texto vital (2016); (ed.) Jorge Semprún. Fronteras $\mid$ Frontières (2018).

Beatriz Miranda Galarza. PhD en Sociology and Disability Studies por la Universidad de Leeds (Inglaterra). Máster en Antropología con Especialización en Desarrollo y Discapacidad (Universidad Católica de Lovaina, Bélgica), Máster en Estudios Latinoamericanos (Universidad de los Parlamentos Andinos Simón Bolívar). Especialista en Desarrollo Social (Instituto Tecnológico de Monterrey). Licenciatura en Sociología y Ciencias Políticas (Universidad Central del Ecuador). Ha sido profesora en la Universidad de Leeds, la Universidad de Ámsterdam y del Amsterdam University College. Ha estado a cargo de las cátedras de Problemas sociales contemporáneos, Sociología y Antropología Médica, Métodos de investigación participativa, Discapacidad e Investigación. Es integrante de 17, Instituto de Estudios Críticos de México en el que coordina el área de estudios críticos de la discapacidad y salud. Hasta 2016 coordinó el proyecto SARI y BRIDGES dirigidos al trabajo con personas afectadas por la enfermedad de Hansen (lepra), que han desarrollado alguna discapacidad, en Indonesia y Brasil. Está involucrada en proyectos de investigación y capacitación relacionados con lepra y discapacidad en Ecuador, Nepal, Myanmar, Brasil e Indonesia. Desde 2010 trabaja en la formación de personas con discapacidad y lepra en investigación acción participativa en Myanmar, Timor Leste, Indonesia, Brasil y Nepal. Ha estado vinculada al campo de la discapacidad y lepra y el fortalecimiento de instituciones con y para personas con discapacidad en América Latina y Asia 
a través de su trabajo con distintas organizaciones internacionales, por más de 24 años. Hasta el año pasado trabajó entre Europa y Asia y actualmente radica en México. Líneas de investigación: familia y discapacidad, discapacidad intelectual, conocimiento personal y enfermedad de Hansen, investigación acción participativa. Publicaciones recientes: con Patrick Devlieger (eds.), Rethinking disability: World perspectives, cultures and societies (2016); (ed.), Nuestra historia no es mentira: Vivir con "lepra" en Ecuador (2017).

Katarzyna Nowak-McNeice. Licenciada en Filología Inglesa por la Universidad de Wroclaw (Polonia), habilitación sobre la identidad californiana en literatura. Docente e investigadora en Wroclaw, Berlín, Londres, Los Angeles (investigadora Fullbright), Fullerton y Madrid. Desde el año 2015, investigadora Conex-Marie Curie en la Universidad Carlos III de Madrid. Líneas de investigación: poshumanismo, literatura y teoría poscolonial, literatura estadounidense, feminismo y antiespeciesismo. Publicaciones recientes: con Agata Zarzycka (ed.), A Dark California: Essays on Dystopian Depictions in Popular Culture (2017); traducción de Autistic Son, Desperate Dad (de Rafal Motriuk, 2018); California and the Melancholic American Identity in Joan Didion's Novels: Exiled from Eden (2019).

David Ojeda Abolafia. Director de la Cía. Palmyra Teatro, Profesor de Dirección Escénica en la RESAD, Doctor por la Universidad de Alcalá con tesis en Artes Escénicas y Discapacidad. Colaborador en las Jornadas de Inclusión Social en las Educación y la Artes Escénicas-INAEM; experto en Artes Escénicas, Inclusión y Accesibilidad; Socio de la Asociación de Directores de Escena de España. Publicaciones recientes: "Medio siglo de artes escénicas y diversidad funcional en España”, en ¿Discapacidad? Literatura, teatro y cine hispánicos vistos desde los disability studies. Ed. Julio Checa y Susanne Hartwig (2018).

Ryan Prout. Alumno de Totton Sixth Form College; estudios de doctorado en filología hispánica en Trinity Hall, Cambridge University. Research Lecturer at Oxford University de 1996 a 2000 y desde 2012 Senior Lecturer en Español in Spanish at Cardiff University. Líneas de investigación: culturas visuales y narrativas contemporáneas de España y de Hispanoamérica, Disability Studies, Comics y Medicina gráfica, etología, estudios LGBT, estudios de dolor y escatología. Publicaciones recientes: "Wrinkles, Furrows, and Laughter Lines: Paco Roca in Conversation at the Lakes International Comic Art Festival", en International Journal of Comic Art (2018); "Within, Against, Inside, Out: Ian Padrón, Fuera de liga, Habanastation, and Music Video", en Cinema of Cuba: Contemporary Film and the Legacy of Revolution (2017). 
Christian von Tschilschke. Licenciado en Filología Románica y Eslava por la Universität Heidelberg (Alemania). Tesis sobre la escritura cinematográfica en la novela francesa contemporánea, habilitación sobre la relación entre la formación del sistema literario y el discurso de identidad en el siglo XVIII español. De 2007 a 2019 catedrático de Literaturas Románicas en la Universität Siegen, desde abril 2019 en Münster. Coeditor de la Revista Iberoamericana. Líneas de investigación: la literatura y los medios de comunicación (cine, televisión), la literatura francesa y española contemporánea, la literatura y cultura en la España del siglo XVIII, los estudios de género, la docuficción, el discurso colonial español respecto a África y el cine francés, español y latinoamericano. Publicaciones recientes: con Maribel Cedeño Rojas e Isabel Maurer Queipo (ed.), Lateinamerikanisches Kino der Gegenwart. Themen, Genres/Stile, RegisseurInnen (2015); con Bernhard Chappuzeau (ed.), Nuevo Cine Argentino: nuevas relaciones entre estética y política (2016); con Jan-Henrik Witthaus (ed.), El otro colonialismo. España y África, entre imaginación e historia (2017).

Javier Luis Velloso Álvarez. Licenciado en Filología Hispánica por la Universidad de Oviedo y Máster en Lengua y Literatura Españolas Actuales por la Universidad Carlos III de Madrid. Desde el año 2017, becario predoctoral y docente en la Universidad Carlos III de Madrid e integrante del Grupo de Estudios de Género en Industrias Culturales y Artes Escénicas (InGenArTe). Líneas de investigación: literatura y compromiso, memoria y literatura y estudios de Género en literatura. Publicaciones recientes: "La visita/La última jugada de José Fouché, de Carmen Resino", en ALEC (2018), "En la orilla, de Rafael Chirbes: pecios de un naufragio anunciado", en Revista de Filología y Lingüística de la Universidad de Costa Rica (2017). 


\section{IMAGES OF DISABILITY / IMÁGENES DE LA DIVERSIDAD FUNCIONAL}

Literature, Scenic, Visual, and Virtual Arts / Literatura, artes escénicas, visuales y virtuales Edited by Susanne Hartwig and Julio Enrique Checa Puerta

Band 1 Julio Enrique Checa Puerto / Susanne Hartwig (ed.): ¿Discapacidad? Literatura, teatro y cine hispánicos vistos desde los disability studies. 2018.

Band 2 Susanne Hartwig (ed.): Inclusión, integración, diferenciación. La diversidad funcional en la literatura, el cine y las artes escénicas. 2020.

www.peterlang.com 
